UNIVERSIDADE DE BRASÍLIA (UNB)

PROGRAMA DE PÓS-GRADUAÇÃO EM HISTÓRIA

DIRCEU MARCHINI NETO

O PRIORADO DO CRATO DA ORDEM DO HOSPITAL E AS DINÂMICAS DE PODER NA ÉPOCA DO PRIOR D. VASCO DE ATAÍDE (1453-1491)

BRASÍLIA - DF 


\section{O PRIORADO DO CRATO DA ORDEM DO HOSPITAL E AS DINÂMICAS DE PODER NA ÉPOCA DO PRIOR D. VASCO DE ATAÍDE (1453-1491)}

Tese apresentada à Comissão Examinadora de Tese de Doutorado do Programa de Pós-Graduação em História da Universidade de Brasília, como parte das exigências para obtenção do grau de Doutor em História. Área de concentração: História Social. Linha de pesquisa: Sociedade, Instituições e Poder.

Orientador: Professor Doutor Celso Silva Fonseca (UnB).

Coorientador: Professor Doutor Fabiano Fernandes (UNIFESP).

BRASÍLIA - DF 


\section{O PRIORADO DO CRATO DA ORDEM DO HOSPITAL E AS DINÂMICAS DE PODER NA ÉPOCA DO PRIOR D. VASCO DE ATAÍDE (1453-1491)}

Tese apresentada à Comissão Examinadora de Tese de Doutorado do Programa de Pós-Graduação em História da Universidade de Brasília, como parte das exigências para obtenção do grau de Doutor em História. Área de concentração: História Social. Linha de pesquisa: Sociedade, Instituições e Poder.

Aprovado em: 11 de agosto de 2015.

BANCA EXAMINADORA

Doutor Celso Silva Fonseca - Universidade de Brasília (Presidente)

Doutora Cláudia Costa Brochado - Universidade de Brasília

Doutor Marcos Aurélio de Paula Pereira - Universidade de Brasília

Doutora Renata Cristina de Sousa Nascimento - Pontifícia Universidade Católica de Goiás

Doutora Armênia Maria de Souza - Universidade Federal de Goiás

Doutor André Gustavo de Melo Araújo - Universidade de Brasília (Suplente) 
Dedico esta obra aos professores Celso Silva Fonseca e Fabiano Fernandes, com gratidão! 


\section{AGRADECIMENTOS}

Algumas pessoas colaboraram tanto para que esta tese fosse escrita que não poderiam deixar de ter seus nomes mencionados nesta seção de agradecimentos, pois merecem ser lembrados por suas competências, sensibilidades e altruísmo.

Agradeço ao Professor Doutor Celso Silva Fonseca, por ter aceitado esta orientação e por ter me apoiado em todos os momentos, sempre demonstrando confiança e me orientando da melhor maneira possível.

Agradeço ao Professor Doutor Fabiano Fernandes, pela enorme ajuda como coorientador desta tese, por ter me acompanhado durante meses na redação do projeto de pesquisa para o Exame de Qualificação e por nunca ter me abandonado nesta caminhada, mesmo durante os meses em que estive ausente. Foi o Professor Fabiano quem me abriu a mente para a compreensão dos contextos mediterrânico e intercontinental nos quais a Ordem do Hospital estava inserida durante os séculos XIV, XV e XVI.

Agradeço também à Professora Doutora Renata Cristina de Sousa Nascimento por me fazer gostar imensamente de História Medieval, desde os tempos em que fora minha professora na Licenciatura em História; por ter me dado a mão e me colocado no caminho correto para meu engrandecimento profissional.

Agradeço à Professora Armênia Maria de Souza, da Universidade Federal de Goiás, também minha professora na Licenciatura em História, conselheira acadêmica, exemplo de profissional e de ser humano; com certeza alguém que inspira e ilumina a todos ao seu redor.

Agradeço ao Doutor Saul António Gomes, Professor Associado da Faculdade de Letras e do Instituto de Paleografia e Diplomática da Universidade de Coimbra, pelas várias orientações via e-mail e via Facebook e pelo envio de diversas obras bibliográficas que facilitaram as análises dos temas pesquisados.

Agradeço ainda ao Professor Doutor Henrique Modanez de Sant`Anna, meu colega, meu conselheiro, meu maior ídolo na carreira docente. Talvez, se não o tivesse conhecido, não teria iniciado a Graduação em História em 2008, não teria tomado gosto pelo magistério ou pelo menos não teria conseguido chegar ao doutoramento em História, pois desde o início o tive como fonte de motivação.

Agradeço à Professora Doutora Adriana Vidotte, Presidente da Associação Brasileira de Estudos Medievais (ABREM), instituição da qual fui Tesoureiro durante um ano, graças a 
um convite que me fora feito por ela para integrar sua chapa nas eleições de 2013. Minha significativa admiração!

Agradeço à Professora Maria Filomena Pinto da Costa Coelho, por sempre demonstrar como ser uma professora compreensiva, humilde, interessada em ajudar alunos e colegas e por confiar na minha capacidade enquanto aluno do Doutorado em História da UnB e como professor.

Agradeço aos demais professores do Programa de Pós-Graduação em História da Universidade de Brasília, pela qualidade do ensino ministrado, pela dedicação e pelo excelente exemplo de ética profissional. Com este corpo docente, com o qual cursei cinco disciplinas e um estágio docente, aprendi que a formação de um pós-graduando não é baseada apenas em uma dissertação ou tese, mas num conjunto de ensinamentos que são repassados ao longo das aulas, da conclusão dos créditos e da orientação do trabalho de final de curso.

Agradeço imensamente aos coordenadores e corpos docentes das instituições de ensino nas quais ministrei aulas durante os anos em que cursei este doutoramento (20102015). Aos colegas da Pontifícia Universidade Católica de Goiás, da Universidade Federal de Goiás (Regional Jataí), das Faculdades Objetivo, do Instituto Aphonsiano de Ensino Superior, da Faculdade de Inhumas e do Colégio Visão; minha eterna gratidão pelas oportunidades, pela aprendizagem e pelo companheirismo.

Agradeço aos meus pais, avós, tios e amigos, pelo suporte emocional que propiciou a conclusão desta tese, além da agradável companhia em diversos momentos em que a pressão se tornava demasiado elevada, tornando minha vida mais alegre.

Agradeço à Ordem DeMolay, da qual participei dos dezesseis aos vinte e cinco anos de idade, tendo a honra de receber diversos títulos e homenagens, por ter me apresentado à história das Ordens do Templo e do Hospital, criando e fazendo crescer minha grande fascinação pelos estudos das ordens militares medievais.

Agradeço ainda a estimada Professora Maria Cristina Almeida e Cunha Alegre, que me ensinou dedicadamente Paleografia, quando fora minha professora de Paleografia e Diplomática na Faculdade de Letras da Universidade do Porto. Sem os métodos e técnicas ensinados por essa inesquecível professora esta tese jamais teria sido escrita.

Agradeço à minha esposa, amiga e eterna companheira, Bárbara Rosa, pelos anos em que esteve comigo em Portugal, acompanhando meus estudos acerca da Ordem do Hospital, pelos quatro anos e meio nos quais me apoiou a continuar o doutoramento, por ter em todo esse tempo me ajudado a superar crises depressivas e circunstâncias contrárias à conclusão desta tese. Só ela sabe o que passei nesses últimos anos, o sofrimento, a angústia e o 
desespero por ter que lidar com uma carga pesadíssima de trabalho, concluir uma Licenciatura em História e ainda ter forças para escrever a tese de doutorado, praticamente duas vezes. Sem ela eu não seria nem o professor, nem o pesquisador e nem o ser humano que sou hoje. Sei que a caminhada para a perfeição nunca acaba, mas enquanto ela estiver ao meu lado continuarei caminhando.

Antes de concluir, agradeço com incomensurável gratidão à pessoa que possibilitou direta e indiretamente a escolha do tema desta tese e o desenvolvimento dos estudos acerca da Ordem do Hospital em Portugal, a Professora Doutora Paula Maria de Carvalho Pinto Costa, docente da Universidade do Porto e pesquisadora de Ordens Militares na Idade Média. Sem a leitura da sua vasta obra sobre a atuação dos cavaleiros hospitalários em Portugal, também seria impossível escrever esta tese. Agradeço pelos dois anos em que fora minha orientadora no Mestrado em História Medieval e do Renascimento (2008-2010), na Universidade do Porto; agradeço pelas várias vezes em que respondera meus e-mails, pelas diversas ocasiões em que me indicara textos para leituras e pelas vezes em que estivera no Brasil proferindo palestras sempre esclarecedoras.

Por fim, agradeço a Deus por ter me inspirado a ter forças quando minha mente e meu corpo já não resistiam mais. É verdade que nunca fui devoto o suficiente para poder acreditar em milagres, mas sou realmente consciente para agradecer a excessiva quantidade de graças que acontecem na minha vida. 
Explicar por que alguma coisa aconteceu e narrar o que aconteceu coincidem. A frase narrativa, que é a marca definidora do discurso histórico, revela a presença do passado. Narrar é seguir e compreender uma história. Ricoeur.

O real não é uma globalidade a ser reconstruída. Não há o real, mas representações discursivas que o constituem. Foucault. 


\section{RESUMO}

Esta tese de doutoramento apresenta uma análise sobre o Priorado do Crato da Ordem do Hospital, desde a instalação dos hospitalários no Condado Portucalense até o fim da gestão do Prior D. Vasco de Ataíde, com foco principal no período compreendido entre os anos de 1453 e 1491. Foi analisada a relação entre a relíquia do Santo Lenho, a Batalha do Salado e a transferência da sede portuguesa hospitalária de Leça do Balio para a comenda do Crato. Foi apresentada uma pesquisa acerca da Família Ataíde e sua vinculação com a Coroa de Portugal, enfocando principalmente João e Vasco de Ataíde, irmãos que ocuparam o cargo de prior do Crato. Ao longo da tese também são analisadas as redes de relações sociais do prior do Crato, destacando a relação deste com o monarca português, com o Grão-Mestre da Ordem do Hospital, com o Papa e com as pessoas que compõem a casa prioral, os clientes. Por fim, vale ressaltar que foi ainda pesquisado o papel da Ordem do Hospital nos planos militares da Coroa Portuguesa e sua aliança nas conquistas de Arzila e Tânger (1471), e na Batalha de Toro (1476).

Palavras-chave: Priorado do Crato. Ordem do Hospital de São João de Jerusalém. Vasco de Ataíde. 


\begin{abstract}
This doctoral thesis presents an analysis of the Priory of Crato of the Order of the Hospital of Saint John, since the installation of the Hospitallers in the Condado Portucalense by the end of the mandate Prior Vasco de Ataide, with main focus on the period between the years 1453 and 1491. It analyzed the relation of the Holy Cross relic with the Battle of Salado and the transfer of the Hospitaller Portuguese headquarters from Leça do Balio to Crato. Was presented a research on the Ataide Family and their relationship to the Crown of Portugal, focusing mainly John and Vasco de Ataide, brothers who occupied the post of Prior of Crato. In the thesis are also analyzed the social networks of the prior of Crato, highlighting its relationship with the Portuguese monarch, with the Grand Master, with the Pope and with the people who are part of the priory. We also analyze the performance of the Order in the military plans of the Portuguese Crown. Finally, we studied the alliance between the Priory and the monarchy, in the conquests of Asilah and Tangier (1471), and the Battle of Toro (1476).
\end{abstract}

Keywords: Priory of Crato. Order of the Hospital of Saint John. Vasco de Ataíde. 


\section{LISTA DE IMAGENS}

Imagem 1 - Igreja do Mosteiro de Leça do Balio 38

Imagem 2 - Castelo de Belver

Imagem 3 - Mosteiro da Flor da Rosa/Crato 42

Imagem 4 - Túmulo de D. Álvaro Gonçalves Pereira, em Flor da Rosa 60

Imagem 5 - O Mediterrâneo Oriental em $1450 \quad 88$

Imagem 6 - Grão-Mestre Pierre d'Aubusson em Rodes 95

Imagem 7 - Extensão do Império Otomano (1481-1683) 98

Imagem 8 - Castelo de Rodes $\quad 100$ 
LISTA DE TABELAS

Tabela 1 - Clientela de D. Vasco de Ataíde 
A.B.N.T. - Associação Brasileira de Normas Técnicas

A.D.B. - Arquivo Distrital de Braga

A.D.P. - Arquivo Distrital do Porto

A.N.T.T. - Arquivo Nacional da Torre do Tombo

B.A. - Biblioteca da Ajuda

Cap. - Capítulo

Caps. - Capítulos

Doc. - Documento

D. - Dom/Dona

Ed./ed. - Edição

fl. - fólio

fls. - fólios

Liv. - livro

m. - maço

Ms. - Manuscrito

no - número

OO. MM. - Ordens Militares

p. - página

pp. - páginas

S. - São

$\mathrm{V}$ - verso

Vol. - Volume

Vols. - Volumes 


\section{SUMÁRIO}

1 INTRODUÇÃO

2 PRECEDENTES: O SURGIMENTO DA ORDEM DO HOSPITAL EM JERUSALÉM, SUA ESTRUTURA E MILITARIZAÇÃO

3 O PRIORADO DO CRATO: DO SURGIMENTO AOS TEMPOS DE D. VASCO DE ATAÍDE

3.1 A INSTALAÇÃO DOS HOSPITALÁRIOS EM PORTUGAL

3.2 O SURGIMENTO DO PRIORADO DO CRATO

3.3 A FAMÍLIA ATAIIDE: OS PRIORES JOÃO DE ATAIIDE E VASCO DE ATAIIDE

4 O PRIORADO DO CRATO E O REINO DE PORTUGAL

4.1 D. VASCO DE ATAÍDE E OS MONARCAS DE SUA ÉPOCA

5 AS DINÂMICAS DE PODER NO MEDITERRÂNEO

5.1 O PRIOR DO CRATO E O CONVENTO CENTRAL DA ORDEM DO HOSPITAL 86

5.2 PRIVILÉGIOS CONCEDIDOS PELA SANTA SÉ

5.3 A POSSÍVEL ALIANÇA ENTRE O PRIOR DO CRATO E O PRIOR DO HOSPITAL EM CASTELA: A BATALHA DE TORO (1476)

6 CONSIDERAÇÕES 


\section{INTRODUÇÃO}

Quando iniciamos o Curso de Doutorado em História na Universidade de Brasília, já havíamos decidido que esta tese iria abarcar a temática da Ordem do Hospital de São João de Jerusalém. Esta escolha se deu com a intenção de darmos seguimento à nossa experiência de pesquisa, que teve início com a redação da dissertação de Mestrado em História Medieval e do Renascimento, cursado na Universidade do Porto (em Portugal); dissertação essa que incidiu sobre o estudo das doações e privilégios recebidos pela Ordem do Hospital no Noroeste da Península Ibérica, entre os séculos XII e XV.

Em Portugal, a Ordem Militar do Hospital de São João de Jerusalém, também chamada de Ordem de São João e, a partir do século XVI, de Ordem de Malta, foi instalada em Leça (atual distrito do Porto) no século XII e foi utilizada como instrumento de consolidação da peregrinação à Santiago de Compostela.

Apesar de indícios que levam parte da historiografia a crer que a Ordem do Hospital estivesse implantada no Condado Portucalense desde $1112^{1}$, somente em 1140 é que podemos dizer que já havia um Priorado Hospitalário em Portugal ${ }^{2}$, cuja primeira sede conventual era o Mosteiro de Leça do Balio. O Priorado era uma unidade administrativa com fins predominantemente econômicos, presidido por um Prior, que tinha atuação restringida pelas determinações do Capítulo Provincial ou Prioral. Esse Priorado era composto por comendas, que eram unidades geográficas e administrativas que continham um núcleo patrimonial, administradas, cada uma, por um Comendador. Comendadores com um grau mais importante eram chamados de bailios.

As comendas eram locais de ascenção ou reprodução das hierarquias. Sabemos, por exemplo, que em Portugal algumas famílias de destaque estavam ligadas a comendas igualmente importantes, comendas que tinham maiores rendimentos, talvez pelo próprio

\footnotetext{
${ }^{1}$ A.D.P., Livro dos Originais do Cabido, Liv. 21 (1679), fl. 9. Este documento contém uma pública-forma de 8 de março de 1340, que apresenta a cópia de uma carta que afirma que em 1130, Martinho, servus pauperum lherosolimitanorum e responsável pelo Mosteiro de Leça, doou à igreja do Porto, na pessoa do seu bispo, D. Hugo, a quintã do Regado, situada na freguesia de Paranhos, para compensar o jantar que o Mosteiro de Leça devia à igreja. Em 1130, esse jantar era supostamente devido há 18 anos, conforme está escrito no documento, o que leva parte da historiografia a crer que os hospitalários já estivessem na região desde 1112 (COSTA, 2000, p. 96). Essa discussão continua no Capítulo 3 desta tese, onde tentamos desconstruir esta interpretação.

2 A.N.T.T., Gavetas, VI, m. ún., no 29 . Este documento menciona uma carta de couto entregue por D. Afonso Henrique ao Mosteiro de Leça, em 30 de março de 1140. Este documento de 1140 é também mencionado num diploma confirmatório de D. Afonso II, de 2 de março de 1218 (A.N.T.T., Gavetas, XV, m. 1, nº 65).
} 
prestígio social de seus comendadores (COSTA, 2000, p. 245). Apresentamos vários casos desses ao longo da tese.

No final do século XII, na região da Beira Interior, sugiu um novo núcleo de implantação territorial hospitalário, localizado inicialmente em torno da terra de Guindimtesta, o atual Gavião/Belver. Foi D. Sancho I que doou à Ordem do Hospital esta terra, em 1194, conforme consta no fólio 8 do Livro dos Herdamentos e Doações do Mosteiro de Leça $^{3}$. Em troca, os freires deveriam construir um castelo (que ficou conhecido como Castelo de Belver), o que demonstra que neste momento, em Portugal, a Ordem já tinha se militarizado, tendo em vista que o castelo deveria cumprir um papel de defesa do que se pensava serem as "fronteiras" do reino ${ }^{4}$. A partir de então, a Ordem do Hospital se desenvolve na região da Beira Interior e amplia seu domínio senhorial e jurisdicional.

Em 1224, D. Sancho II doa aos hospitalários o castelo de Algoso, doação que se enquadra em uma política de defesa e povoamento regional. Em 1232, D. Sancho II ainda doa à Ordem a região do $\mathrm{Crato}^{5}$, esperando que os freires povoassem e protegessem o local ${ }^{6}$. Poucos anos depois, a Ordem do Hospital já havia transferido sua sede conventual de Leça para o Crato. Por isso, ao longo dos séculos o Priorado Português da Ordem de São João de Jerusalém foi chamado de "Priorado do Crato".

Pode-se dizer que a primeira fase da presença das ordens militares em Portugal, caracterizada por doações e privilégios régios e pontifícios ${ }^{7}$, se prolonga até meados do século XIII, quando se inicia um segundo momento da história das ordens militares, as quais, a partir de então, passam por diversas tentativas de controle monárquico. Contudo, essas tentativas apresentam nuances diferentes para cada ordem militar instalada no reino de Portugal $^{8}$.

\footnotetext{
${ }^{3}$ A.N.T.T., Cartório do Bailiado de Leça, Coleção Costa Basto, $n^{\circ} 4$, Livro dos Herdamentos e Doações do Mosteiro de Leça, fl. 8. "Doaçom que fez el rey Dom Sancho aa Ordem do Spital do Castelo de Belveer com sas divisoens e termhos que son conteudos na carta que sobre esto deu ao Spital"

${ }^{4}$ Vale ressaltar que o conceito de fronteira é de difícil definição para reinos ibéricos no período em análise. As fronteiras eram bastante disputadas pelas aristocracias (principalmente pelas que detinham poder político) e ao mesmo tempo pouco demarcadas. No caso de Portugal, fatores linguísticos tinham forte influência para se definir onde terminava o território lusitano e onde começava os reinos vizinhos. Enfim, podemos afirmar que nos séculos XII-XV, as fronteiras de Portugal não eram bem definidas geograficamente, inclusive por falta de recursos tecnológicos para tal.

${ }^{5}$ A.N.T.T., Cartório do Bailiado de Leça, Coleção Costa Basto, $n^{o} 4$, Livro dos Herdamentos e Doações do Mosteiro de Leça, fl. 8. "Item carta d'el rey Dom Sancho per que deu o Crato con seus termhos ao Spital".

${ }^{6}$ A.N.T.T., Gavetas, VI, m. ún., no 22. Pode-se ler no respectivo documento: “...ut faciatis ibi populationem et fortelezam...".

${ }^{7}$ Em Portugal há dois documentos que trazem um rol de privilégios régios e pontíficos recebidos pelos hospitalários nos séculos XII-XV, os quais estão parcialmente transcritos como anexos desta tese de doutoramento. Estes documentos são: o Livro dos Herdamentos e Doações do Mosteiro de Leça, arquivado no Arquivo Nacional da Torre do Tombo, cuja cota é Cartório do Bailiado de Leça, Colecção Costa Basto, $n^{\circ} 4$; e a Regra da Ordem de São João de Jerusalém, existente na Biblioteca da Ajuda, com a cota 49-II-32.

${ }^{8}$ Não é um dos objetivos desta pesquisa analisar essas tentativas monárquicas de controlar as ordens militares em Portugal, o que deixamos para um futuro trabalho.
} 
Após o fim da Reconquista em Portugal, os monarcas começaram a impor regras que nortearam a operacionalidade das ordens militares. Em muitas ocasiões, a monarquia tentou usar as ordens militares em benefício próprio (COSTA, 2012, p. 7). Contudo, a Ordem do Hospital, mesmo no século XVI, não passou por um processo de controle semelhante aos das Ordens de Avis, Cristo e Santiago, que foram anexadas à Coroa. Na Ordem do Hospital, desde D. Manuel I, o rei interferiu diretamente na escolha do Prior do Crato, o que demonstra que os monarcas também pretendiam controlar o ramo português desta instituição, porém, pelo fato da Ordem possuir um Convento Central distante de Portugal, atuante na guerra contra o Império Otomano e ligado aos interesses da Cúria Romana (o que de certa forma ia ao encontro dos interesses comerciais portugueses $)^{9}$, ao invés da anexação à Coroa, a medida tomada pelos reis foi a escolha dos priores, indicando pessoas da confiança do monarca. A partir do reinado de D. João III, os priores do Crato passam a ser os infantes ${ }^{10}$.

As ordens militares exerciam prerrogativas jurisdicionais civis $^{11}$ e religiosas ${ }^{12}$ relevantes e, muitas vezes, desempenhavam um papel diplomático crucial em proveito da monarquia. Ordens com largo arco de atuação, como por exemplo, a Ordem do Hospital, possuíam um Mestre sediado em um Convento Central, exercendo forte influência diplomática, inclusive com estreita relação com o Papado, o que justifica a aceitação e o apoio dos reis a essas instituições, que estavam inseridas num vasto contexto de poder $^{13}$.

Deixamos claro, já na epígrafe deste trabalho, que procuramos escrever um texto mais narrativo, criando em certos capítulos sínteses históricas e historiográficas, sem, entretanto, dispensar a análise documental e o cruzamento de dados obtidos nessas analíses com os dados

\footnotetext{
${ }^{9}$ No século XVI, os Turcos eram uma ameaça ao comércio marítimo português com a Índia. Sabe-se que em 1514 foi interceptada uma armada Turca que pretendia carregar madeira para galés e navios do Sultão, com o intuito de destruir a armada de Portugal na Îndia (A.N.T.T., Corpo Cronológico, Liv. I, m. 11, nº 61).

${ }^{10}$ Em 1522, D. João III conseguiu do Papa Adriano VI, pelo breve Exposuit nobis, a autorização para a nomeação de um dos infantes com mais de seis anos para o cargo de Prior do Crato (A.N.T.T., Bulas, m. 23, ${ }^{\circ}$ 19). No mesmo ano, o mesmo Papa expediu mais um breve informando ao monarca de que não poderia aceder às suas súplicas (A.N.T.T., Bulas, m. 13, $\mathrm{n}^{\circ}$ 12). Contudo, em 1524, o Papa Clemente VII retomou a questão e pediu ao Grão-Mestre dos hospitalários que não se intrometesse no provimento do Priorado de Portugal (A.N.T.T., Bulas, m. 15, no 25 e Gavetas, VI, m. ún., no 294). Em 1528, o infante D. Luís, irmão de D. João III, após atingir a maioridade, assume o cargo de Prior, ao qual renucia em $1551 \mathrm{em}$ favor de seu filho, D. Antônio.

${ }^{11}$ A Ordem do Hospital em Portugal possuía, dentre outras prerrogativas civis, o direito de firmar contratos enfitêuticos (o que demonstra seu caráter senhorial), direito de criar monopólios, direitos fiscais e exercício da justiça (COSTA, 2000, p. 352).

${ }^{12}$ Podemos citar com exemplos de prerrogativas jurisdicionais da Ordem do Hospital: proteção apostólica do Sumo Pontífice (Bula Pie Postulatio voluntatis); imunidade a medidas punitivas dos prelados diocesanos sobre suas igrejas; isenção aos freires de Ordem de terem que jurar fidelidade e homenagem aos bispos; permissão para recolha de esmolas em igrejas; isenção de pagamento de dízimos, como de outros direitos episcopais; isenção de ter que receber visitações diocesanas, etc. (COSTA, 2000, pp. 135-140).

${ }^{13}$ Entendemos que o poder está presente não somente no governante, ou seja, na classe dominante, mas que está presente em múltiplas redes socioespaciais que se cruzam e se imbricam. O poder pode ser ideológico, econômico, militar e político. A compreensão do poder requer ainda a compreensão da cultura política de determinada época e lugar. Nesse sentido, seguimos o racicíonio de Peter Burke (2002, p. 108-113).
} 
da bibliografia lida. Concordamos com Chartier (1990) e Ricoeur (1994), quando dizem que a história, em todas as suas formas, mesmo as mais estruturais, pertence ao campo narrativo. Acreditamos que toda escrita histórica é uma narrativa, que quase sempre não representa o que de fato ocorreu, pois é uma representação construída pelo sujeito e que se aproxima da ficção ${ }^{14}$.

Citando José Carlos Reis (2006, p. 139):

O que controla esse seu caráter ficcional é o fato de a atividade mimética não terminar no texto poético ou na obra de história. Ela se dirige e se realiza no espectador ou leitor. Ela retorna ao vivido. A refiguração ou reinvenção da intriga é produzida pelo receptor, que se torna coautor A compreensão narrativa articula uma atividade lógica de composição - o autor - com a atividade histórica de recepção - o público. O que realiza essa articulação? Um prazer, o de aprender pelo reconhecimento.

O que se propôs foi uma pesquisa sobre as relações do Priorado do Crato com o Convento Central, com a Coroa Portuguesa, com o Papado, com os reis de Castela e com os outros freires hospitalários que lutavam na guerra contra o Império Otomano no período em análise (1453-1491) ${ }^{15}$. Ao longo da tese, analisamos o papel de alguns priores do Crato que mantiveram contatos diretos com a monarquia lusitana, com freires hospitalários de reinos vizinhos e com o Convento Central da Ordem, enfatizando a atuação de D. Vasco de Ataíde durante sua titulatura, sua participação nas Batalhas de Tânger e Arzila (África, 1471), em vários Capítulos Gerais na ilha de Rodes, e noutros projetos bélicos da Coroa de Portugal, ao lado de D. Afonso V e de D. João II, como por exemplo, na Guerra de Sucessão Castelhana. A delimitação temporal escolhida, 1453 a 1491, marca o período compreendido entre o primeiro registro e o último registro encontrados, que citam D. Vasco de Ataíde à frente do Priorado do Crato $^{16}$.

\footnotetext{
${ }^{14}$ Nosso conceito de narrativa coincide com o de Heloisa Selma Fernandes Capel (2006, p.6), que diz: "Para alguns, a narrativa é a casca da laranja metafórica. A que nos permite o reconhecimento como sujeitos hermenêuticos. Para outros, têm importância em si mesmas. Narrar o mundo, é conferir-lhe sentido. Narrar o mundo pela história é apropriar-se do tempo. Narrar uma história não é apenas um modo de relembrá-la, mas também um meio para reconfigurar nossa experiência de tempo. Narrar é uma forma de dar existência à memória, e de lidar com o tempo, que só se torna humano por este meio". "Narrar o mundo pela história é, também, conscientizar-se das habilidades retóricas, as da linguagem, a do controle dos documentos, especialmente naquilo que trazem de importante para a legitimação do discurso historiográfico".

${ }^{15}$ Pelo fato de não existir documentação expedida pelo Convento Central da Ordem do Hospital referente a este período, assim como de não existirem documentos expedidos pelo Prior de Portugal ao Convento Central, não nos foi possível fazer uma análise aprofundada sobre a relação deste priorado com o Grão-Mestre dos Hospitalários.

${ }^{16} \mathrm{Na}$ verdade, o penúltimo registro que relaciona D. Vasco de Ataíde ao Priorado do Crato é de 1487 (A.N.T.T., Gavetas, XI, m. 7, no 10 e Leitura Nova, Direitos Reais, 1. 1, fls. 85v-88v.), entretanto, a documentação só atesta o exercício no cargo de Prior por outro cavaleiro em 1492, D. Diogo Fernandes de Almeida, que tinha sido eleito
} 
Também foram discutidos os valores e a perspectiva dos priores quanto a determinadas questões, como por exemplo, a guerra contra os muçulmanos, e neste aspecto o estudo puro e simples da trajetória é apenas auxiliar.

Sintetizando: a proposta desta tese é o estudo do surgimento do Priorado do Crato e deste período de trinta e oito anos, a partir da análise das redes sociais que se constituem ao redor e por meio da figura do Prior. Essas redes não se limitam ao plano local e tão pouco às fronteiras de um reino ou apenas ao quadro cronológico de um reinado. Definimos a delimitação temporal entre 1453 e 1491, mas sabemos que os processos internos da Ordem nem sempre estão em consonância com as cronologias das gestões de priores.

A organização estrutural da tese será composta por um Capítulo 1 - Introdução, um segundo capítulo intitulado Precedentes: o surgimento da Ordem do Hospital em Jerusalém, sua estrutura e militarização, um terceiro capítulo intitulado O Priorado do Crato: do surgimento aos tempos de D. Vasco de Ataíde, um quarto capítulo denominado O Priorado do Crato e o Reino de Portugal, um quinto capítulo As Dinâmicas de Poder no Mediterrâneo, e, por fim, um Capítulo 6 - Considerações, além de uma seção Fontes e Bibliografia e um Anexo ${ }^{17}$.

No Capítulo 2, de forma introdutória, foi feita uma síntese bibliográfica acerca do surgimento da Ordem do Hospital em Jerusalém e sobre sua instalação na Península Ibérica. Neste segundo capítulo, analisamos a estrutura social e administrativa da Ordem, a prática de assistência e o processo de militarização da instituição.

No terceiro capítulo, foi feita uma investigação acerca da instalação e expansão da Ordem de São João em Portugal e o surgimento do Priorado do Crato, assim como analisamos os vários contextos históricos nos quais o Priorado estava inserido, dando grande destaque para a relação entre a relíquia do Santo Lenho, a Batalha do Salado e os freires do Hospital. Por fim, neste Capítulo 3, discorremos sobre a ascensão de D. Vasco de Ataíde ao cargo de Prior do Crato e também apresentamos uma breve análise prosopográfica acerca da família Ataíde.

O quarto capítulo da tese refere-se às intervenções da Coroa Portuguesa no Priorado do Crato, através de doações, privilégios, vínculos familiares e solicitações diversas. Começaremos analisando por que Portugal tinha interesse em apoiar a guerra da Ordem do

em 1480, mas que só assumiu o cargo posteriormente (FREIRE, 1996, p. 361). Entendemos que a gestão de Vasco de Ataíde tenha terminado somente em 1492, pois em 1491 seu nome ainda aparece como representante da Ordem do Hospital em um contrato de emprazamento de três vidas, sobre bens situados na comenda de Távora. A.D.B. Comendas, Távora (Santa Maria de), nº 50, doc. 15.

${ }^{17}$ Relembramos que, de acordo com as normas da A.B.N.T., a Introdução deve ser o primeiro capítulo e as Considerações ou Considerações Finais o último. 
Hospital contra o Império Otomano, demonstrando que os interesses comerciais e expansionistas envolvendo a África e a Índia estavam diretamente ameaçados pelos ataques Turcos às armadas portuguesas no Mediterrâneo e em terras e mares da Ásia ${ }^{18}$. Além disso, em algumas ocasiões a monarquia portuguesa inseriu os hospitários em seus projetos políticomilitares contra outros reinos cristãos ibéricos. Exemplo disso foi a aliança entre o Priorado do Crato e a Coroa de Portugal na Batalha de Toro.

No Capítulo 5, analisamos as relações do Prior D. Vasco de Ataíde com o Convento Central da Ordem, com o Papado e com o Prior Hospitalário de Castela, D. Juan de Valenzuela, na ocasião da Batalha de Toro, 1476.

No que diz respeito à tipologia das fontes, foram analisadas diversas fontes documentais e bibliográficas, das quais as principais cito a seguir.

O segundo capítulo da tese diz respeito ao surgimento da Ordem do Hospital em Jerusalém, no contexto do Movimento de Cruzada, e sua posterior instalação na Península Ibérica. Para estudarmos o surgimento da Ordem no Oriente Médio, foram consultadas diversas obras historiográficas consagradas, de autores, como por exemplo, Jonathan RileySmith, Alain Demurger, Carlos Barquero Goñi, Helen Nicholson, Karl Borchardt, Carlos de Ayala Martínez, dentre outros. Ou seja, este capítulo se configura mais como uma em formato de síntese histórica, apresentando a bibliografia mais atualizada acerca do tema.

No terceiro capítulo analisamos a instalação dos hospitalários no Reino de Portugal e o surgimento do Priorado do Crato. Para tais análises, nossos principais referenciais teóricos foram as diversas obras de Paula Maria de Carvalho Pinto Costa, as obras de Martim de Albuquerque e de Conde de Campo Bello; três obras de produção historiográfica dos séculos XVIII e XIX relacionanadas ao tema, a citar: os três livros sobre a História da Ordem de Malta em Portugal, escritos por José Anastásio de Figueiredo Ribeiro, respectivamente em 1793, História da Ordem do Hospital, hoje de Malta, dos Senhores Grão-Priores Della em Portugal (Volumes I e II), e em 1800, Nova História da Militar Ordem de Malta, e dos Senhores Grão-Priores Della, em Portugal (Volume III); além da obra escrita pelo Fr. Lucas de Santa Catharina em 1734, Malta Portugueza. Memorias da Nobilíssima e Sagrada Ordem dos Hospitalários de S. João de Jerusalém, especialmente do que pertence à Monarchia Portugueza.

Com relação à principal documentação analisada para a escrita do terceiro capítulo, temos dois documentos manuscritos referentes aos hospitalários portugueses: o Livro dos

${ }_{18}$ A.N.T.T., Corpo Cronológico, Liv. 1, m. 4, nº 74; Liv. 1, m. 11, nº 61; e Liv. 2, m. 7, n 56. A.N.T.T., Chancelaria de D. Manuel I, Liv. 11, fl. 6 
Herdamentos e Doações do Mosteiro de Leça, conservado no Arquivo Nacional da Torre do Tombo, em Portugal, pertencente à Colecção Costa Basto, do Cartório do Bailiado de Leça e catalogado com o número 4, e a Regra da Ordem de São João de Jerusalém, guardada na Biblioteca da Ajuda, também em Portugal, catalogada com o código 49-II-32. Parte dos fólios desses documentos referem-se à documentação régia e pontifícia que beneficia o ramo português da Ordem do Hospital como um todo ${ }^{19}$. No entanto, também há no Livro dos Herdamentos referências aos privilégios de algumas comendas específicas.

Ainda foi bastante analisada no terceiro capítulo a documentação publicada no Volume 16 da Coleção Militarium Ordinum Analecta, intitulado A Comenda de Vera Cruz de Marmelar. Corpus Documental (1258-1640), cuja coordenação é de Luís Adão da Fonseca.

Com relação aos capítulos 4 e 5, a documentação utilizada foi bastante diversificada. Foram analisados diversos documentos manuscritos durante o tempo em que estivemos em Portugal fazendo pesquisas no Arquivo Nacional da Torre do Tombo, onde pudemos ver de perto alguns códices e solicitar fotocópias de outros. Dos manuscritos, podemos citar: as coleções de Chancelaria Régia (D. Afonso III, D. Dinis, D. João II, D. Afonso V, D. Manuel), Leitura Nova (Além Douro, Beira, Direitos Reais, Estremadura, Guadiana, Legitimações, Mestrados e Místicos), Bulas e Colecção Especial de Bulas, Gavetas, Corpo Cronológico, Núcleo Antigo, Cortes, Livro dos Herdamentos e Doações do Mosteiro e Leça, dentre outros.

Vale ressaltar que também foram consultados documentos do Arquivo Distrital do Porto (Livro dos Originais do Cabido) e do Arquivo Distrital de Braga (Comendas, Santa Maria de Távora). Além disso, tivemos acesso à documentação já transcrita e publicada, o que verdadeiramente facilitou bastante nosso trabalho, a citar as Gavetas da Torre do Tombo. Todas as cotas constam na seção Fontes e Bibliografia desta tese, após o último capítulo ${ }^{20}$.

Para tratarmos do Cerco de Rodes, em 1480, fez-se necessária a análise do documento Opera Guillelmi Caousin, Rhodiorum vicecancellarii: Obsidionis Rhodiae Urbis Descriptio, de Guillaume Caousin, arquivada na Bibliothèque Nationale de France, com a cota Res. K-89 (disponibilizada integralmente na internet $)^{21}$.

\footnotetext{
${ }^{19}$ Estes dois documentos estão parcialmente transcritos e anexados a esta tese. As partes transcritas são as que se referem aos privilégios régios e pontíficos da Ordem do Hospital em Portugal. Ver "Anexo I".

20 A quantidade de fontes mencionadas nesta Introdução foi possível ser analisada devido a dois fatores: o primeiro deles é o fato de esta pesquisa ter tido início em 2008, época em que iniciei o Mestrado na Universidade do Porto sobre esta mesma temática; o segundo fator é o fato de ter ficado em Portugal durante um tempo em 2013, a fim de ter contato com a documentação e solicitar digitalizações ao Arquivo Nacional da Torre do Tombo. De lá para cá, tive ainda dois anos para trabalhar com a documentação e ler toda a bibliografia. São poucos documentos transcritos ou manuscritos e poucas as obras bibliográficas que eu não tenha cópia ou digitalização sob minha guarda.

${ }^{21}$ Vale ressaltar que analisamos a versão publicada e traduzida para o Inglês dessa obra de Guillaume Caousin, intitulada Siege of Rhodes, pela Editora Alex Murray and Son, de Londres, cuja tradução é de Johan Kaye.
} 
Sobre as relações entre o Priorado do Crato e a Coroa Portuguesa, as principais coleções documentais impressas e publicadas utilizadas foram: Crónica de D. João II e Miscelânea, de Garcia de Resende; Chronica de El Rei D. João II e Chronica de El Rei D. Afonso V, ambas de Rui de Pina; As Gavetas da Torre do Tombo, editadas por Miguel Jasmins Rodrigues; o Livro dos Forais, Escrituras, Doações, Privilégios e Inquirições da Ordem de Malta, publicado por José da Cunha Saraiva; Brasões da Sala de Sintra, de Anselmo Braacamp Freire; Documentos Medievais Portugueses, de Rui de Azevedo; a Monumenta Henricina, do Organizador Manuel Lopes de Almeida, dentre outros.

A necessidade de se analisar tão dispersa documentação, com relação à presença dos hospitalários em terras lusitanas, justifica-se pelo fato de atualmente não haver um núcleo documental da Ordem de São João de Jerusalém em Portugal, pelo menos não há nenhum referente aos séculos XII e XV, e nem mesmo crônicas que apresentem como protagonista a instituição produzidas neste período. Restam-se assim as fontes avulsas, as quais "relatam episódios particulares da vida dos freires de S. João" (COSTA, 2000, p. 41) e que na maioria das vezes só eram escritas “devido à faceta econômica da sua organização".

De acordo com Paula Pinto Costa (2000, pp. 42-43):

No Arquivo Nacional da Torre do Tombo, mais concretamente no núcleo relativo ao Cartório do Bailiado de Leça, está conservado o Livro dos herdamentos e doações do mosteiro de Leça, como pertencente à Colecção Costa Basto e catalogado com o $n^{\circ}$ 4. Trata-se de um códice com 162 fólios, 'tornado a lume e concertado...' pelo Grão Chanceler Fr. Cristovão de Cernache Pereira, cavaleiro professo da Ordem, Bailio de Leça e membro do conselho régio. Esta compilação contém os '...herdamentos e doações deste mosteiro de Leça e de outras comendas e das liberdades e privilegios dos reys de Portugal e de Hespanha concedidos a Ordem de São Joam Bautista do Hospital de Jerusalem...' e foi concluída em Leça a 24 de Fevereiro de 1551. Com este livro, poderíamos ser levados a pensar que estamos perante o cartório da Ordem do Hospital em Portugal. Mas, este pensamento é inconsistente, uma vez que, como já dissemos, estes sumários não contém uma data e, raras são as vezes, em que se contemplam outros elementos indicadores do tempo em que tiveram lugar as acções neles mencionadas. No entanto, o seu valor histórico é indiscutível, se atendermos ao facto de se tratar de um livro produzido numa época determinada - o século XVI -, num espaço concreto - Leça - e da responsabilidade do Grão Chanceler da instituição Fr. Cristovão de Cernache Pereira. Convém, também, acentuar o facto de, em princípio, quem o redigiu ter presente um elenco documental, indispensável à elaboração e registo dos sumários da documentação que estava a compulsar, revelando que, pelo menos até essa época, havia um núcleo documental, cuja organização se fazia de acordo com a existência de diversas comendas 
É provável que a Ordem do Hospital tenha mantido um "cartório" antes da escrita do Livro dos Herdamentos e Doações do Mosteiro de Leça (1551-61?), entretanto, esse núcleo documental não chegou até nossos dias, talvez por causa da destruição causada pela incursão de D. João de Áustria nas terras do Crato, em 1662, no contexto da guerra de restauração da dinastia de Bragança. No século XVII, o Castelo do Crato era a sede do Priorado da Ordem de Malta em Portugal e, provavelmente, onde se guardava o "cartório" da instituição. Há outros fatores que podem ter colaborado ou sido os únicos a causarem uma possível destruição da documentação dos hospitalários portugueses, como por exemplo, o terremoto de 1531, o grande terremoto de 1755 e a anexação da Ordem à Casa do Infantado em $1789^{22}$.

Para estudar os contextos político, militar e comercial "português" e "mediterrânico" dos séculos XV e XVI, nos quais estavam inseridos a Ordem do Hospital, a monarquia portuguesa, o Papado e o Império Otomano, baseamo-nos em diversas obras bibliográficas, como por exemplo, Crusading in the Fifteenth Century: message and impact, de Norman Housley; The Later Crusades: from Lyons to Alcazar 1274-1580, também de Norman Housley; The Papacy and the Levant (1204-1571), de Kenneth M. Setton; The Hospitallers, the Mediterranean and Europe, de Karl Borchardt [et al.]; The Hospitallers of Rhodes and Their Mediterrean World, de Anthony Luttrell; The Making of Christian Malta: from the Early Middle Ages to 1530, também de Anthony Luttrell; The Crusades and the Expansion of Catholic Christendom, 1000-1714, de John France; Renaissance Diplomacy, de Garrett Mattingly; The New Cambridge Modern History, de G. R. Potter; Court and Politics in Papal Rome 1492-1700, de Gianvittorio Signorotto e Maria Antonietta Visceglia; The Ottoman Empire and Early Modern Europe, de Daniel Goffman; e Empires of the Sea: The Siege of Malta, the Battle of Lepanto and the Contest for the Center of the World, de Roger Crowley.

Além disso, para analisar as relações entre Portugal e Espanha e para comparar os ramos hospitalários da Língua de Castela e Portugal, lemos as seguintes obras ${ }^{23}$ : Relações entre Portugal e Castela nos Finais da Idade Média, de José Marques; Los Caballeros Hospitalarios Durante la Edad Media en España e Los Hospitalarios en la España de los Reyes Católicos, ambas de Carlos Barquero Goñi; Caballeros de Cristo: Templarios, Hospitalarios, Teutónicos y Demás Órdenes Militares en la Edad Media (Siglo XI-XVI), de Alain Demurger; La Soberana Ordem de Malta a Través de Diez Siglos de Historia y su

${ }^{22}$ A Casa do Infantado, instituição patrimonial dos segundos filhos dos monarcas, foi criada em 1654 e extinta em 1834.

${ }^{23}$ Não era objetivo desta pesquisa comparar o ramo hospitalário de Portugal com outros ramos da Ordem na Península Ibérica, mas a leitura dessas obras se fez necessária na medida em que nos propusemos a analisar a aliança entre o Prior do Crato D. Vasco de Ataíde e o Prior de Castela D. João de Valenzuela, no contexto da Batalha de Toro (1476). 
Relación con la Acción Humanitaria, de Rafael Pérez Peña; História de Portugal (Volumes 2 e 3), cuja direção é de José Mattoso; História de Portugal, de Rui Ramos [et al.], dentre outras.

Enfim, buscamos produzir uma obra historiográfica que se enquadrasse na área de concentração do Programa de Pós-Graduação em História da Universidade de Brasília (UnB), "História Social", e na linha de pesquisa por nós escolhida, "Sociedades, Instituições e Poder", apresentando, portanto, uma abordagem bastante específica a respeito das dinâmicas de poder no Priorado do Crato da Ordem do Hospital, durante o período compreendido entre 1453 e 1491.

Sob certo ponto de vista, a obra pode ser considerada original na medida em que a historiografia brasileira não apresenta produções que abordem a temática do Priorado do Crato a partir da atuação de seus priores, neste caso a partir das relações de poder nas quais estava inserido um prior específico. Sequer conhecemos uma obra produzida no Brasil a respeito exclusivamente da Ordem do Hospital. Quase a totalidade da bibliografia lida foi produzida na Península Ibérica e no Reino Unido, sendo o conjunto da obra de Paula Pinto Costa a única escrita (e atualizada) já no século XXI, excepcionalmente a respeito dos hospitalários em Portugal durante a Idade Média. No decorrer do nosso texto, às vezes tornam-se frequentes citações diretas ou indiretas de obras desta autora, o que se deu pela sua vasta produção bibliográfica sobre o assunto e sobre a inexistência de outros autores a respeito de determinados temas.

Além disso, procuramos contestar alguns enunciados históricos tidos como certos, como por exemplo, a tese consolidada em Portugal sobre a instalação dos hospitalários no Condado Portucalense. Buscamos esclarecer questões obscuras para a historiografia, como por exemplo, a origem familiar e morte de D. Vasco de Ataíde, diferenciando-o do Vasco de Ataíde, seu sobrinho, navegador de Pedro Álvares Cabral. Também buscamos originalidade na forma de analisar a história do Priorado do Crato, relacionando documentação com uma vasta bibliografia, a fim de conseguir apresentar ao leitor várias temporalidades, diferentes contextos políticos, questões militares, assuntos religiosos, análises sociais acerca de alguns ramos nobiliárquicos envolvidos com a Ordem do Hospital e, obviamente, tendo em alto relevo, como eixo central, a figura do Prior do Crato.

Vale ressaltar que a historiografia portuguesa sobre as ordens militares, principalmente a parte da historiografia que trata dessas instituições em Portugal, apresenta uma forma semelhante de discurso, "quase" sempre analisando a maneira como os monarcas se relacionavam com as milícias, colocando o rei como o principal objeto de estudo. Em nossa 
tese de doutorado tentamos não repetir esse discurso no qual o monarca ou os reinados são o foco da análise, apesar de que em algumas abordagens isso não foi possível. Tentamos apresentar uma abordagem narrativa diferenciada, na qual o Priorado do Crato e os priores são o centro e a atuação régia é uma das dinâmicas de poder que afetam a Ordem do Hospital em Portugal. 


\section{PRECEDENTES: O SURGIMENTO DA ORDEM DO HOSPITAL EM JERUSALÉM, SUA ESTRUTURA E MILITARIZAÇÃO}

Marc Bloch disse em sua Apologia da História ou o Ofício de Historiador (BLOCH, 2001) que o profissional da História deveria escrever sempre de forma clara, para que qualquer enunciado histórico fosse plenamente compreensível tanto para doutos quanto para leigos. Nessa perspectiva, entendemos ser bastante interessante uma abordagem de contextualização sobre a Ordem do Hospital, seu surgimento em Jerusalém, sua expansão e uma explicação geral sobre os precedentes da chegada dos hospitalários à Península Ibérica.

Os cristãos peregrinavam até Jerusalém, sobretudo a partir do século IV, "quando Helena, mãe do primeiro imperador cristão Constantino, descobriu a verdadeira Cruz" ${ }^{24}$. Constantino mandou construir ao lado da anastasis, prédio que albergava o sepulcro de Cristo, uma basílica. Para um cristão, rezar onde viveu Jesus Cristo e a Virgem Maria era como meditar mais perto de Deus. Naquele local, os peregrinos praticavam uma espécie de vida ascética e, voluntariamente, se penitenciavam (DEMURGER, 2005, p. 33).

Com a conquista árabe, em 638, os peregrinos passaram a ter que aceitar guias muçulmanos e a peregrinação ficou afetada pelas modificações da conjuntura política no mundo islâmico. Os cristãos ocidentais começaram a peregrinar em grupos, pois esta forma de viagem proporcionava maior segurança. A partir do século IX, Carlos Magno tentou fazer funcionar uma política de proteção dos lugares sagrados, mas quem protegeu efetivamente os cristãos orientais e manteve o Santo Sepulcro durante todo o período muçulmano foi o imperador bizantino.

Mais de um século antes da Primeira Cruzada, houve vários acordos entre alguns soberanos europeus e líderes islâmicos, com o escopo de construção de hospitais e hospícios cristãos na Terra Santa, nos quais pudessem ser atendidos os peregrinos que visitavam os lugares sagrados. O monge Bernardo, em 865, alegava que ao próprio imperador Carlos Magno se deveu a fundação, após um acordo com o califa Harún al-Rachid, de um desses hospícios, o qual estava junto a uma igreja dedicada à Santa Maria. Ainda segundo Bernardo, "gracias al emperador, el hospicio poseía una preciosa biblioteca, doce casas, campos, viñedos y un huerto en el valle de Josafat" (DEMURGER, 2005, p. 34). Este hospício ficava muito próximo de outras igrejas cristãs, como por exemplo, a Igreja de Santa Maria Latina e a

\footnotetext{
${ }^{24}$ Mito amplamente difundido pela Cristandade.
} 
basílica construída por Constantino. Alain Demurger (2005, p. 35) afirma que foi neste bairro latino, onde se encontrava o Sepulcro, que se viria a concretizar o conceito de ordem militar.

Após alguns problemas durante o califado de al-Hakim (996-1021), califa do Cairo que por um tempo perseguiu judeus e cristãos, a peregrinação ocidental se intensificou. Em 1027, o imperador Constantino VIII e um novo califa fatímida fizeram um acordo que permitiu a restauração das igrejas destruídas décadas antes. A anastasis foi reformada e reinaugurada em 1048, o que provocou um intenso fluxo de bizantinos à Jerusalém. Destas transações entre cristãos orientais e mulçumanos, o resultado foi um crescente comércio que envolvia Constantinopla, a Síria palestina e alguns mercadores de Amalfi ${ }^{25}$, que já se encontravam instalados em Jerusalém. Esses comerciantes da Península Itálica quiseram construir um hospital próximo ao Santo Sepulcro, e assim o fizeram entre 1048 e 1063, além de terem mandado reconstruir (ou construir, no caso do mosteiro) o Mosteiro e a Igreja de Santa Maria Latina ${ }^{26}$. Essas obras realizadas pelos mercadores de Amalfi foram colocadas sob a proteção de São Bento e entregues aos cuidados de monges italianos cluniacenses, que deveriam acolher quantos peregrinos fosse necessário ${ }^{27}$. Os monges de Santa Maria ainda construíram, posteriormente, um mosteiro feminino sob os cuidados de Santa Maria Madalena, no qual foi instalada uma comunidade de monjas encarregadas de acolher as mulheres peregrinas.

Apesar de existirem dois mosteiros para albergar peregrinos (um masculino e outro feminino), ambos se tornaram insuficientes, o que levou os monges de Santa Maria Latina a construírem um hospital dedicado a São João Esmoler ou a São João Batista ${ }^{28}$. Entretanto, vale observar que entre os anos 1071 e 1098, Jerusalém ficou sob domínio dos Turcos seljúcidas, que apesar de aparentemente não terem impedido que os cristãos fizessem ou

\footnotetext{
${ }^{25}$ Carlos de Ayala Martínez (2007, p. 40), explica que os amalfitanos foram bem recebidos no Oriente Médio e que receberam todo tipo de privilégios por parte das autoridades islâmicas, pois comercializavam produtos muito desconhecidos pelos muçulmanos até aquele momento.

${ }^{26}$ Ainda segundo Alain Demurger (2005, p. 36), a cronologia de todas as construções mencionadas não é segura.

${ }^{27}$ Carlos de Ayala Martínez (2007, p. 41), apresenta um relado de Guilherme de Tiro, o qual escreveu que quando os peregrinos chegavam à Terra Santa, sejam nobres ou miseráveis, já chegavam absolutamente pobres, esfomeados, sedentos e quase nus. E ainda por cima, precisavam ter moedas de ouro para pagarem aos muçulmanos, para posteriormente adentrarem a Jerusalém. Depois que conseguiam acesso aos locais sagrados, de tão pobres precisavam pedir alojamento nos mosteiros amalfitanos, os quais eram insuficientes para hospedar essas pessoas.

${ }^{28}$ Sobre o santo padroeiro do hospital há muita discordância entre os pesquisadores. Alain Demurger, (2005, p. 36), explica que alguns historiadores acreditam que o hospital já fora fundado sob a proteção de São João Batista, mas que Jonathan Riley-Smith e Alain Beltjens acreditam que primeiramente a proteção do hospital era dada por São João Esmoler. Vale ressaltar que Carlos de Ayala Martínez (2007, p. 41), também considera que quando os monges amalfitanos construíram o hospital em torno de uma terceira igreja, decidiram dedicar estes institutos ao caritativo patriarca do século VII João de Alexandria, cujo amor aos pobres lhe valeu a alcunha de "Esmoler". Naquele momento, passavam a existir três fundações amalfitanas, sem rendas nem posses e que só viviam das esmolas anuais que os comerciantes reuniam entre quem voluntariamente desejava contribuir.
} 
reformassem muitos prédios, eram quem autorizava qualquer tipo de construção não muçulmana. Mesmo assim, Alain Demurger (2005, p. 36) acredita que as construções dos mosteiros e do hospital aconteceram entre 1079 e 1089.

A administração do novo hospital foi entregue pelos monges beneditinos a um leigo chamado Gerardo de Saint-Geniez ${ }^{29}$, muito conhecido como o Hospitalário "por ser muito piedoso". É provável que Gerardo fosse também amalfitano. Voluntariavam no hospital, além de Gerardo, outros leigos que levavam uma vida religiosa sem serem monges e, segundo Alain Demurger (2005, p. 37), "tenían el estatuto de cofrade, cuando no de lego en el caso de los más humildes". Pode até ser que Gerardo não estivesse em seu posto durante a Primeira Cruzada, mas o certo é que foi ele quem dirigiu o hospital após 1099.

Segundo Helen Nicholson (2011, p. 5):

Before the capture of Jerusalem by the First Crusade, Gerard's hospice had been dependent on the monastery of the St Mary of the Latins, and its members probably followed an adapted version of the Rule of St Benedict, which was the monastic rule followed by the monastery. At that time the patriarch of Jerusalem, the priests in charge of the Holy Sepulchre, and the ecclesiastical hierarchy all belonged to the Syrian Orthodox Church. After Jerusalem fell to the crusaders, a Latin Christian patriarch was established in the Holy Sepulchre, with canons (priests) following a religious communal lifestyle to serve the spiritual needs of the pilgrims, and a Latin Christian ecclesiastical hierarchy was put in place throughout the newly conquered territories. The focus of Latin Christian authority in Jerusalem therefore shifted; all Latin Christian institutions were now answerable to the Latin Patriarch, based in the Church of the Holy Sepulchre. It seems that the Hospital now came under the direct authority of the canons of the Church of the Holy Sepulchre.

Depois da Primeira Cruzada e após a reconquista de Jerusalém pelos cristãos, houve um imenso fluxo de pessoas da Europa para o Oriente Médio e também no sentido contrário. Os cruzados também eram peregrinos e precisavam de albergues e hospitais, da mesma forma que qualquer outro cristão que não tinha residência fixa na Palestina. Acerca das necessidades dos cruzados, Paula Pinto Costa (2000, pp. 51-52) escreveu o seguinte:

A motivação para a luta contra os inimigos da fé de Cristo foi uma constante e, por isso mesmo, muitos fiéis eram estimulados à peregrinação à Terra Santa, com o intuito de revelarem a sua aproximação a Deus, pela cooperação num projecto que significava fortalecer o reino de Cristo na terra dos homens. Nestas peregrinações, o longo tempo de viagem agravava as já precárias condições de higiene e dieta alimentar, que associadas às

\footnotetext{
${ }^{29}$ Carlos Andrés González-Paz (2009, pp. 9-44) afirma que Gerardo de Saint-Geniez foi generosamente dotado
} por Godofredo de Bulhão. 
dificuldades de alojamento e falta de descanso, expunham os peregrinos, que procuravam salvar a alma, a uma debilidade física favorável à contracção de numerosas doenças. Parecia, assim, estar latente uma coexistência entre a cura do espírito e o mal do corpo dos peregrinos. Importava, por isso, receber cuidados assistenciais que minorassem todo o mal estar físico.

Após a tomada de Jerusalém pelos cristãos, e considerando o aumento do número de peregrinos, Gerardo construiu um novo e maior hospital, pois também havia adquirido a Igreja de São João Batista. Em 15 de fevereiro de 1113, o Papa Pascoal II, pela Bula Pie postulatio voluntatis ${ }^{30}$, ofereceu reconhecimento ao hospital como instituição independente e diretamente protegida pelo Papa. Através daquele documento, o Hospital se convertia em ordem caritativa intercontinental, afiliada a outros hospícios criados na Europa (DEMURGER, 2005, p. 37). A partir de então, o santo padroeiro do Hospital passava a ser São João Batista, e sua regra deixava de ser a de São Bento e passava a ser (pelos menos na prática) inspirada na de Santo Agostinho. A importância que adquiriu a nova instituição exigia um patrono mais significativo do que o pouco conhecido São João Esmoler.

Segundo Jonathan Riley-Smith (2010, p.15):

The origins of the Hospital predated those of the Temple. A hospice or hospital for pilgrims was established in ca. 1080 by the only Latin institution at the time in Muslim Jerusalem, the Benedictine abbey of St. Mary. The hospital's independence of the abbey was confirmed by Pope Paschal II in 1113. It has been suggested that until the Hospitallers composed their own Rule, perhaps twenty years later, they comprised a lay community, but Paschal himself referred to them as frates professi, and a Rule was not a requirement for a religious institute to be authentic. The Carthusians did not have a Rule. St. Francis did not wont one. It is likely that the nucleus of the new society was made up of Benedictine frates conversi (serving brothers). These men were establishing, in Kaspar Elm's phrase, a "self-standing order of conversi", which must have provided the model a few years later of the founders of the Temple, who of course had different aims.

Sobre a regra da Ordem do Hospital, Helen Nicholson escreveu o seguinte (2011, p. 5):

The evidence for this change in the Hospital's position comes from the many charters to the early Hospital which give donations to 'the Holy Sepulchre and the Hospital of St John of Jerusalem', indicating that the two were

\footnotetext{
${ }^{30}$ Segundo Paula Maria de Carvalho Pinto Costa (2000, p. 52), “através desta bula, o Papa conferiu à Ordem do Hospital isenção em relação ao poder episcopal, garantiu a sucessão do responsável pela comunidade, através de um processo eleitoral interno, em que participariam os irmãos professos, e imprimiu força econômica aos institutos, confirmando todas as doações que tivesse recebido até a data e isentando-a do pagamento do dízimo sobre as suas terras".
} 
linked, or even that they were one and the same. It would have been reasonable for the canons of the Holy Sepulchre to have taken over responsibility for oversight of the Hospital: their religious lifestyle, with its active work in the Christian community, was far more like that of the people serving in the Hospital than the work of the monks of St Mary of the Latins, who fallowed an enclosed lifestyle according to the Rule of St Benedict. The similarities between the earliest known Rule of the Hospital, ascribed to Master Raymond du Puy (1120-1158/60), and the Rule of St Augustine suggest that the Hospital's Rule was influenced by the canons of the Holy Sepulchre, who formally followed the Rule of St Augustine from 1114.

Com o passar dos meses, os hospitalários de São João ou Irmãos do Hospital de São João de Jerusalém haviam mostrado um crescente protagonismo no âmbito do complexo monástico do qual faziam parte, instituíram maneiras de sustentação sob a forma de rendas e terras e criaram uma extensa rede organizativa que alcançava o Ocidente através da fundação de casas dependentes. Em poucos anos, a nova ordem religiosa já estava consagrada no panorama eclesiástico da Cristandade e, assim sendo, foi dotada, por Raimundo de Puy, de uma norma reguladora (tornada oficial em 1113), adaptada da chamada regra agostiniana, que fora confirmada posteriormente pelo Papa Eugênio III (AYALA MARTÍNEZ, 2007, p. 43).

Depois da queda de Jerusalém, em 1187, a Ordem do Hospital transferiu sua sede para São João de Acre, de onde foi expulsa, procurando refúgio na Ilha de Chipre em 1291. Em 1309, com a derrota cipriota se sediaram na Ilha de Rodes, a qual foi tomada do Império Bizantino. Durante mais de duzentos anos Rodes foi a base das atividades defensivas dos hospitalários, em face do avanço islâmico no Mar Mediterrâneo. Nesta ilha, a Ordem criou um principado independente, onde permaneceu quase como uma "Ordem Estado" (BARQUERO GOÑI, 2006, p.20).

No século XV, a Ordem do Hospital sofreu forte pressão exercida pelos muçulmanos, os quais decidiram atacar a Ilha de Rodes. O sultanato mameluco do Egito atacou em 1440 e em 1444, e os Turcos otomanos investiram contra a ilha em 1480 e em 1522. Em 1523, os hospitalários foram obrigados a abandonar sua sede conventual.

Vale ressaltar que depois de 1480, a Ordem do Hospital torna-se bastante prestigiada entre os cristãos, o que influencia diretamente as dinâmicas internas das Línguas e Priorados da instituição ${ }^{31}$. A vitória hospitalária no cerco de Rodes, em 1480, elevou o status dos cavaleiros dessa milícia; ou seja, manter a presença hospitalária tornou-se um fim em si mesmo, pelo fato de terem resistido ao poderoso cerco Turco (HOUSLEY, 2004, pp 149162). Posteriormente, em 1522, a perda da Ilha de Rodes enfraqueceu um pouco a reputação

\footnotetext{
${ }^{31}$ Os Priorados estavam inseridos em unidades administrativas ainda maiores, chamadas Línguas. No caso do
} Priorado do Crato, Língua de Castela e Portugal. 
dos cavaleiros hospitalários. Entretanto, o prestígio da Ordem é retomado em 1565, quando com a ajuda das tropas do Imperador Felipe II, o Convento Central, já sediado na Ilha de Malta, resiste mais uma vez a um ataque $\operatorname{Turco}^{32}$.

Depois da capitulação de Rodes, em 1522, e após um período em Trípoli, os hospitalários fixaram residência conventual na Ilha de Malta, que em 1530 lhes foi entregue pelo imperador Carlos V (COSTA, 2000, p. 54). Essa concessão se realizou revestida de um caráter de feudo, pois a Ordem ficou obrigada a pagar um valor anual simbólico ao rei da Sicília pelo reconhecimento da soberania. Nos anos seguintes, a Ordem do Hospital passou a ser chamada de Ordem de Malta (BARQUERO GOÑI, 2006, p.21) ${ }^{33}$.

Já na Ilha de Malta, a Ordem do Hospital sofreu um ataque do sultão otomano, em 1565, e os hospitalários saíram vencedores. A partir de então, a Ordem de Malta serviu como uma espécie de "policía marítima en el mediterráneo para proteger a la navegación occidental de los ataques de la piratería islámica procedente del norte de África" (BARQUERO GOÑI, 2006, p.21) ${ }^{34}$.

Em 1798, Napoleão Bonaparte, durante uma escala de sua expedição ao Egito, se apoderou da Ilha de Malta e expulsou o Grão-Mestre e o Convento da Ordem. Em 1803, depois de um período de dispersão, reúne-se sob um novo Grão-Mestre, Frei Giovanni Battista Tomasi. Em 1834, foram estabelecidos a sede e o governo em Roma, onde possui, até os dias atuais, com extraterritorialidade, o Palácio da Via Condotti e a Villa Aventino.

Faziam parte da Ordem do Hospital homens e mulheres. Assim como outras ordens militares, o Hospital era uma instituição religiosa específica, caritativa e guerreira, que possuía formas de recrutamento diferenciadas ${ }^{35}$.

Os que professavam na Ordem eram freires, que eram divididos em três categorias distintas: os cavaleiros, os sacerdotes e os serventes, coadjuvados em suas atividades por numerosas pessoas ligadas à instituição. "Os freires professavam os três votos substanciais da vida religiosa (obediência, castidade e pobreza) e viviam de acordo com preceitos normativos próprios" (COSTA, 2010, p. 18).

\footnotetext{
${ }^{32}$ No cerco de Malta, em 1565, houve a participação de cavaleiros portugueses, dos quais cerca de vinte e quatro morreram em combate e seus nomes estão registrados numa placa da Catedral de Valletta (ALBUQUERQUE, 1998, p. 20).

${ }^{33}$ Sobre este assunto consultar: LUTTRELL, Anthony. The Hospitallers of Rhodes and their Mediterranean World. Edição Reimpressa. Hampshire: Ashgate Publishing, 2002; e LUTTRELL, Anthony. The Making of Christian Malta: from the Early Middle Ages to 1530. Hampshire: Ashgate Publishing, 2002.

${ }^{34}$ Segundo este autor, a Ordem do Hospital também sentiu o impacto da Reforma Protestante e sofreu muitas perdas patrimoniais na Europa continental, onde parte dos bens hospitalários foi secularizada.

${ }^{35}$ Sobre o recrutamento de recursos humanos, ver: COSTA, 2000; DEMURGER, 2005; e RILEY-SMITH, 2012.
} 
Por ser a Ordem do Hospital, uma organização jurisdicionalmente isenta de prerrogativas episcopais, tendo em vista que dependia diretamente do Sumo Pontífice, por quem era protegida desde a época de Pascoal II (1113), não se pode identificar essa ordem como uma ordem monástica. "Se bem que os objetivos inspiradores do clero regular fossem comuns a todos os seus membros, isto é, todos eles pretendiam adquirir um estado de perfeição..." (COSTA, 2000, p. 49).

Os freires viviam uma vida em comum em Conventos que variavam muito de tamanho. Na Europa, os Conventos eram agrupados por comendas (unidades de administração e exploração econômica) e administrados por comendadores (ou preceptores). As comendas ou preceptorias eram agrupadas em províncias chamadas priorados, comendas capitulares ou castelanias capitulares, que eram administradas por bailios capitulares, que eram os comendadores ou castelãos no Leste Europeu, geralmente nomeados pelo Capítulo Geral da Ordem. No final do século XII, algumas províncias europeias puderam ser agrupadas em grandes comendas, as bailiagens (RILEY-SMITH, 2012, p. 97). As comendas compunham os priorados, que compunham sete Línguas (ou Nações). Essas Línguas eram as seguintes: Provença, Alvernia, França, Itália, Hispania, Alemanha e Inglaterra. As Línguas eram subdivididas em unidades territoriais e administrativas menores, os priorados, que eram subdivididos em bailiagens e comendas.

Segundo Paula Pinto Costa (2000, p. 103):

De uma forma pragmática podemos dizer que uma comenda é um determinado conjunto de bens, gerido por um freire professo, que exerce o cargo de comendador, e cujo funcionamento conta com muitas outras pessoas, tanto pertencentes à hierarquia da instituição, como com uma numerosa massa de indivíduos, relacionados com a exploração indirecta da terra, de cuja administração resulta um rendimento. Esta definição geral aplica-se a todas as Ordens Militares presentes no reino. Em relação à Ordem do Hospital, existem quatro tipos de comendas, de acordo com os comendadores e os motivos que presidiram à sua colocação à frente de cada uma delas. Assim, temos as chamadas comendas de Cabimento (administradas por um freire professo - cavaleiro, capelão conventual ou servente de armas - por um período de cinco anos, podendo ser renovável), de Melhoramento (entregue a um comendador apto, também por um período de cinco anos), de Graça (trata-se de uma comenda entregue pelo Grão Mestre a um cavaleiro distinto, igualmente por cinco anos) e, por fim, as Magistrais (em que o Grão Mestre reserva para si os frutos do rendimento, entregando a sua administração a quem entendesse). Esta estrutura de comendas já conserva em si vários elementos que interessam à atribuição de cada uma delas, uma vez que conta com critérios previamente estabelecidos, embora não seja fácil apurar o grau de fidelidade com que estas obrigações eram cumpridas. 
Havia ainda um Convento Central da Ordem, cujos oficiais eram chamados de bailios conventuais. Esses oficiais eram oito: o Grão-Comendador, o Marechal, o Grão-Hospitalário, o Almirante, o Drapier ou Conservador, o Grão-Bailio, o Grão-Chanceler e o Turcopolier ou General da Cavalaria. "Em termos de governo, contava com a figura do Grão-Mestre e de vários órgãos colegiais, dos quais se destacava o Capítulo Geral, sendo respeitada uma estrutura hierárquica bem definida" (COSTA, 2000, p. 49). No âmbito dos priorados, haviam Capítulos Priorais ou Provinciais, dos quais faziam parte o prior, os comendadores e os bailios.

A Ordem do Hospital também aceitava irmãs, freiras, que eram responsáveis por diversos tipos de serviços caritativos em hospitais, além de viverem, principalmente, de forma contemplativa. Havia laços entre as casas masculinas e as femininas que configuravam uma relação bastante estreita entre esses dois ramos. Contudo, as mulheres viviam em casas separadas dos homens.

Além dos membros freires e freiras, existiam pessoas particulares laicas, os donatos, que ofereciam seu patrimônio à Ordem do Hospital, com o objetivo de participarem na concessão de benefícios espirituais que a instituição parecia assegurar (COSTA, 2000, p. 64).

Pode-se dizer que ainda havia outras pessoas ligadas à Ordem, como por exemplo, os peregrinos e cruzados, que muito concorreram para que os objetivos da instituição fossem alcançados; os confreires, laicos que comparticipavam anualmente e comungavam das orações feitas pelos capelães e participavam dos benefícios espirituais ligados aos hospitalários; e até mesmo funcionários em geral, alguns inclusive na condição de servos, que prestavam serviços à Ordem (COSTA, 2000, p. 65).

A assistência, entendida na forma mais ampla possível, era a ação prioritária desenvolvida pela Ordem do Hospital de São João de Jerusalém. Assim era expresso em sua regra e foi para esta causa que a Ordem fora criada.

[...] a sua origem, ligada à Terra Santa e, particularmente, ao cuidado dos peregrinos que aí se deslocassem, foi determinante nos objectivos e no percurso que estes religiosos viriam a desenvolver. $O$ facto de serem membros de uma ordem religiosa também poderá ter agido como um elemento integrador desta sua função, que se afigurava um meio privilegiado de mostrarem que estavam activos junto dos mais necessitados e, sobretudo, daqueles que procuravam uma aproximação a Deus, através de Jesus Cristo (COSTA, 2000, p. 87).

Havia nas enfermarias, além de médicos, enfermeiros, boticários e um capelão ou prior de enfermaria, o qual era responsável pelo tratamento da alma dos enfermos, pois se o 
corpo estava debilitado, o espírito se encontrava "mais exposto ao chamamento de Deus" (COSTA, 2000, p. 87).

De acordo com Paula Pinto Costa (2010, p. 19):

Dentro deste espírito, a enfermaria era a unidade física que melhor expressava este programa de acção. No seu seio eram tratados, de forma modesta, tanto os freires professos como as pessoas seculares que procuravam o apoio da Ordem. Havia diferentes oficiais que exerciam funções na enfermaria, desde o enfermeiro, obrigado a visitar todas as noites os enfermos e a ter ao seu serviço criados que participassem no serviço, bem como duas mulheres honestas para criar os meninos órfãos que fossem cristãos, aos pródomos, que trabalhavam em parceria com o oficial anterior, passando pelos médicos, obrigados a passar visita, pelo menos duas vezes por dia, na presença do enfermeiro e do escrivão, para que a estes dois últimos profissionais fosse possível proceder à concretização das instruções dadas pelos primeiros. Acrescente-se, ainda, os cirurgiões, que seriam também dois, e o boticário que, como responsável pela farmácia, tinha que assegurar o seu aprovisionamento e participar na distribuição dos remédios. O cuidado dos enfermos era complementando com a prestação de cuidados espirituais, assegurados pelo capelão ou prior da enfermaria, a quem cabia celebrar a missa, administrar os sacramentos e presidir às cerimónias fúnebres de todos os que morressem.

A função hospitalária das ordens militares entrou em crise no final da Idade Média. A falta de recursos fez com que algumas cidades deixassem de garantir a administração da maioria dos hospitais. Entretanto, a Ordem do Hospital continuou praticando essa função quando sediada em Rodes e depois em Malta, durante os séculos XVI a XVIII (DEMURGER, 2005 , p. 181$)^{36}$.

Assim como a maioria das ordens militares, a Ordem de São João também possuía uma dimensão colonizadora, o que permitiu sua legitimação social e explicou suas próprias dinâmicas de crescimento e expansão. A Ordem do Hospital, durante séculos, colaborou com a articulação social, econômica e administrativa dos reinos, especialmente nos reinos ocidentais, e, desta forma, favoreceu a configuração do modelo feudal de relações. Citando as palavras de Ayala Martínez (1995, p. 35):

[...] cuando hablamos de "colonización" por parte de la Orden de San Juan, estamos aludiendo a un complejo mundo de iniciativas colaboradoras con el poder político, que van desde la reordenación humana y paisajística de las zonas de su responsabilidad señorial - lo que tradicionalmente se viene llamando "repoblación" -, a sus tareas en apoyo de la articulación socioadministrativa de los espacios fronterizos, pasando por su concreto

\footnotetext{
${ }^{36}$ Vale ressaltar, a assistência aos necessitados é o objetivo principal da Ordem de Malta na atualidade, século
} XXI. 
protagonismo en el proceso de dinamización económica que suposo la puesta en marcha de los grandes y rentables circuitos de la ganadería trashumante.

Além da prestação de cuidados assistenciais e do aspecto colonizador, a Ordem do Hospital também exerceu ações militares, como forma de servir ao ideal proposto pela Igreja e responder às exigências de uma época e de uma sociedade repleta de violência e disposta a guerrear. Já no século XII, a Ordem de São João de Jerusalém, criada com a finalidade única de praticar a caridade para com os necessitados, passou a se militarizar ${ }^{37}$.

Acerca da questão da militarização da Ordem do $\operatorname{Hospital}^{38}$, alguns historiadores afirmam que se deu precocemente, por volta de 1136 ou antes, e outros pesquisadores alegam que aconteceu tardiamente, até 1160. O que podemos concluir é que, de fato, a militarização do Hospital aconteceu depois da aprovação da regra da Ordem do Templo, em 1129, que a partir desta data já era uma ordem religiosa militar cristã, provavelmente fruto dos conceitos islâmicos da jihad e, talvez, do ribat $^{39}$. É verdade que a partir de 1136, os hospitalários passaram a receber diversos castelos e fortalezas como doações, sobretudo no Oriente latino. Neste ano, o rei Fulco de Jerusalém entregou ao Hospital o recém construído castelo de BeitJibrin, que ficava próximo à fronteira do reino. Em 1144, o conde Raimundo II de Trípoli doou uma série de fortalezas à Ordem, incluindo o Crac, também em terras de fronteiras territoriais. Em 1153, os hospitalários participaram ativa e militarmente do cerco de Ascalon (AYALA MARTÍNEZ, 2007, p. 45) . $^{40}$

Apesar de todos esses argumentos, nenhum documento comprova que antes de 1182 a Ordem do Hospital já possuísse características e estruturas militares. No ano 1140, o Papa Inocêncio II precisou enviar uma carta a todos os prelados da Cristandade, solicitando deles colaborações para a obtenção de esmolas em benefício dos hospitalários. Na carta, era

\footnotetext{
${ }^{37}$ Entretanto, precisamos ressaltar que na Península Ibérica o dever principal dos hospitalários era o apoio e envio de recursos humanos e materiais para a defesa e mantimento de seu convento central no Oriente Latino (o qual representava uma das principais bases operacionais de Cruzada no Mediterrâneo Oriental). Sobre este assunto: BARQUERO GOÑI, 2003, p. 155.

${ }^{38}$ Sobre a militarização da Ordem do Hospital ver, dentre outros, GARCÍA-GUIJARRO RAMOS, 1995, pp. 142-148 e DEMURGER, 2005, p. 344.

${ }^{39}$ Demurger (2007, p. 53) explica, baseando-se em diversos outros historiadores e antropólogos, a questão do empréstimo de modelos islâmicos à Cristandade, especificamente dos modelos de jihad e ribat. Complementando a ideia de Dermurger, podemos afirmar que pelo menos na Península Ibérica, as ordens militares regionais, que surgiram quando a Ordem do Templo já lá estava bem instalada, tiveram origem em confrarias de cavaleiros como as de Belchite e de Monreal (congregações destinadas a praticarem a Guerra Santa contra os muçulmanos), as quais possuíam estruturas similares às ribat islâmicas. Se considerarmos que a Guerra Santa (violência convertida em formas de penitência) e as ordens militares não são noções cristãs, então chegamos à conclusão de que foram adaptações, ainda que reinterpretadas, para serem compatíveis com o Cristianismo.

${ }^{40}$ Carlos de Ayala Martínez ainda explica que em 1148, alguns cavaleiros hospitalários haviam participado da tomada da cidade hispânica de Tortosa.
} 
mencionado que a Ordem precisava de dinheiro para pagar serventes armados que garantissem a proteção dos peregrinos. Este fato nos leva a considerar que, num sentido de totalidade, foi a partir dos anos sessenta do século XII, que a Ordem do Hospital começou a apresentar uma mudança significativa em sua natureza, passando a se militarizar.

De acordo com Riley-Smith (2010, p. 16):

The adoption of military functions by an institution that had been established for a very different purpose was in its way as radical a step as that taken in the foundation of the Temple. "Folk-memories" of the process, preserved in two versions written around 1500, suggest that secular knights, who like the original Templars had come to the East to serve for a few years out of piety or for pay and had attached themselves to the Hospital, were incorporated to form a military class. I have not found any contemporary evidence for paracrusading knights serving the Hospital at an early date, but their needs would explain references from the 1120 s to arm-bearers in the West leaving their horses and weapons to the Hospital in their wills. It has been suggested that Pope Innocent II was aware of these associates - or at least of mercenary sergeants-at-arms - when he referred in the early 1140 s to servients whom the Hospitallers were employing to ensure the safety of pilgrims, although it is possible that he was thinking of the order's provision of a transportation service, centred on the Asnerie, its stables north of Jerusalem's walls. In any case, the Hospital's militarization, like the Temple's, seems to have been born out of the religious aspirations of para-crusading or mercenary knights in Palestine.

Entre os anos 1168 e 1180, o Papa Alexandre III precisou recordar aos hospitalários sobre qual era sua missão primordial, a assistência aos peregrinos, e lhes pediu que não participassem de ações militares, exceto quando o rei de Jerusalém os convocassem para defender o reino (DEMURGER, 2005, p. 46). Contudo, conforme escreveu Paula Pinto Costa (2000, pp. 90-92), é preciso analisar as vicissitudes históricas do local em que cada casa da Ordem se encontrava instalada. Pode ser que na Terra Santa a militarização tenha começado numa determinada época e na Península Ibérica em outra, pois diversos fatores regionais podem ter feito com que alguns freires do Hospital pegassem nas armas mais precocemente. Somente em 1182, depois da inclusão deste assunto na regra, é que aparece a primeira documentação oficial promulgada no Capítulo Geral (estatutos de Rogério des Molins), na qual é mencionada a figura dos frates armorum, ou seja, os cavaleiros e sargentos da Ordem. As estruturas militares propriamente ditas só aparecem documentadas nos estatutos de Margat, de 1203-1206 (GARCÍA-GUIJARRO RAMOS, 1999, pp. 293-302).

Na Península Ibérica, a Ordem de São João se implantou no mesmo século de sua fundação na Terra Santa, antes mesmo de se tornar uma ordem militar. Em Portugal, assim como nos demais reinos ibéricos, os hospitalários foram bem acolhidos e receberam inúmeras 
doações e privilégios. Para retribuírem, os hospitalários prestaram serviços assistenciais e de caráter militar, atuando, em várias ocasiões, como um instrumento do poder real (AYALA MARTÍNEZ, 2007).

Temos indícios, a partir de certos testemunhos, que já no início do século XII havia presença dos hospitalários na Península Ibérica. Primeiramente, a Ordem se instalou na Catalunha. É provável que a casa do Hospital em Cervera já existisse em 1111 (BARQUERO GOÑI, 2003, p.14). Depois, adquiriu patrimônio no reino de Castela, a partir de 1113 (BARQUERO GOÑI, 2006, p.23). Em Portugal, a primeira casa dos hospitalários foi a de Leça do Balio, desde o século XII.

Nos séculos XII e XIII, a Ordem do Hospital obteve apoio maciço de reis e de particulares, os quais lhe fizeram generosas doações, pelo que passou a possuir senhorios muito importantes (BARQUERO GOÑI, 2006, p.25). Até o início do século XIII, houve certo desequilíbrio na distribuição geográfica dos bens hospitalários na Península Ibérica, com predomínio para os reinos orientais (Aragão e Navarra), onde o Hospital chega a ser a ordem militar com maior presença. Assim sendo, o patrimônio hospitalário é menor nos reinos ocidentais (Castela e Portugal), onde predominavam as ordens militares de origem ibérica: Santiago, Calatrava, Alcântara, Avis, etc. (BARQUERO GOÑI, 2006, pp.23-24).

Territorialmente, as possessões ibéricas do Hospital compunham a Língua de Castela e Portugal e se dividiam, desde o século XII, em quatro priorados: Portugal, Castela e Leão, Navarra e Aragão (este último, também conhecido como Castelania de Amposta). No século XIV, surgiu ainda um quinto priorado, o da Catalunha, desmembrado da Castelania de Amposta. Compunham os priorados algumas unidades administrativas de base, que eram as comendas ou bailias, à frente das quais havia um comendador. A origem da maioria das comendas de Portugal remonta aos séculos XII e XIII.

Posteriormente, o Priorado de Portugal passa a ser chamado de Priorado do Crato, após a Ordem do Hospital receber de D. Sancho II os vastos domínios do Crato, em 1232, e lá edificar a Capela da Flor da Rosa, nas décadas de 40 e 50 do século XIV. Flor da Rosa, também uma igreja-fortaleza, em 1356 já oficialmente sede da Ordem em Portugal, encontrava-se na nova centralidade que o reino criara. 


\section{O PRIORADO DO CRATO: DO SURGIMENTO AOS TEMPOS DE D. VASCO DE ATAÍDE}

\subsection{A INSTALAÇÃO DOS HOSPITALÁRIOS EM PORTUGAL}

Data do ano de 1132 o primeiro documento que demonstra a presença da Ordem do Hospital em Portugal. Trata-se de uma doação feita por Zalama Godins a favor dos crúzios, a qual "declara que os cónegos compraram ao vigário do Hospital de Jerusalém, Paio Galindes, por sete morabitinos e meio de ouro, a décima parte dos bens, que ele tinha dado à Ordem do Hospital por sua alma" (COSTA, 2000, p. 93).

Entretanto, alguns pesquisadores afirmam que há indícios de que a Ordem de São João de Jerusalém estivesse implantada em Portugal desde 1112, em Leça. No Arquivo Distrital do Porto, especificamente no Livro dos Originais do Cabido ${ }^{41}$, há um documento que contém uma pública-forma de 8 de março de 1340, que apresenta a cópia de uma carta que afirma que em 1130, Martinho, servus pauperum lherosolimitanorum e responsável pelo Mosteiro de Leça, doou à igreja do Porto, na pessoa do seu bispo, D. Hugo, a quintã do Regado, situada na freguesia de Paranhos, para compensar o jantar (colheita ou contribuição) que o Mosteiro de Leça devia à igreja.

Em 1130, esse jantar era devido há 18 anos, conforme está escrito no documento, o que pode levar historiadores a crerem que os hospitalários já estivessem na região desde 1112. Esta tese foi apresentada por José Anastasio de Figueiredo Ribeiro (1793, p. 24), que já afirmava que as ordens militares até 1130 sempre foram obrigadas a pagar o jantar, "ainda depois das suas maiores liberdades"; e melhor explicada por Paula Pinto Costa (2000, p. 97), principal pesquisadora dos hospitalários em Portugal, que ainda escreveu:

Atendendo ao exposto, podemos pensar que a Ordem do Hospital esteve fixada em Leça pelo menos desde 1112. Esta data pode parecer precoce para a instalação dos freires de S. João em Leça, atendendo à evolução da Ordem em termos gerais, tanto mais se pensarmos que só recebeu bula confirmatória em 1113, se bem que existisse já há alguns anos.

\footnotetext{
${ }^{41}$ ADP (Arquivo Distrital do Porto), Livro dos Originais do Cabido, Liv. 21 (1679), fl. 9.
} 
Contudo, esta tese nos parece pouco sustentável na medida em que em 1113 a Ordem do Hospital já havia recebido a Bula Pie Postulatio Voluntatis, expedida pelo Papa Pascoal II, que reconheceu e colocou a Ordem do Hospital de São João de Jerusalém, como também era chamada, sob a proteção da Sé Apostólica. Com isso, a Ordem passava a dever obediência e subordinação somente ao Papa. Então, por que, em 1130, os hospitalários deviam, há 18 anos, um jantar à igreja do Porto? Não havia submissão dos hospitalários ao bispo do Porto, pelo menos desde 1113, se é que neste período eles já estavam no Condado Portucalense. Além disso, este documento do Livro dos Originais do Cabido (Livro 21, 1679, fl. 9), arquivado no Arquivo Distrital do Porto é uma pública forma de 1340, que apresenta uma cópia de uma suposta carta de 1130, o que torna esta teoria ainda menos convincente.

\section{Imagem 1 - Igreja do Mosteiro de Leça do Balio.}

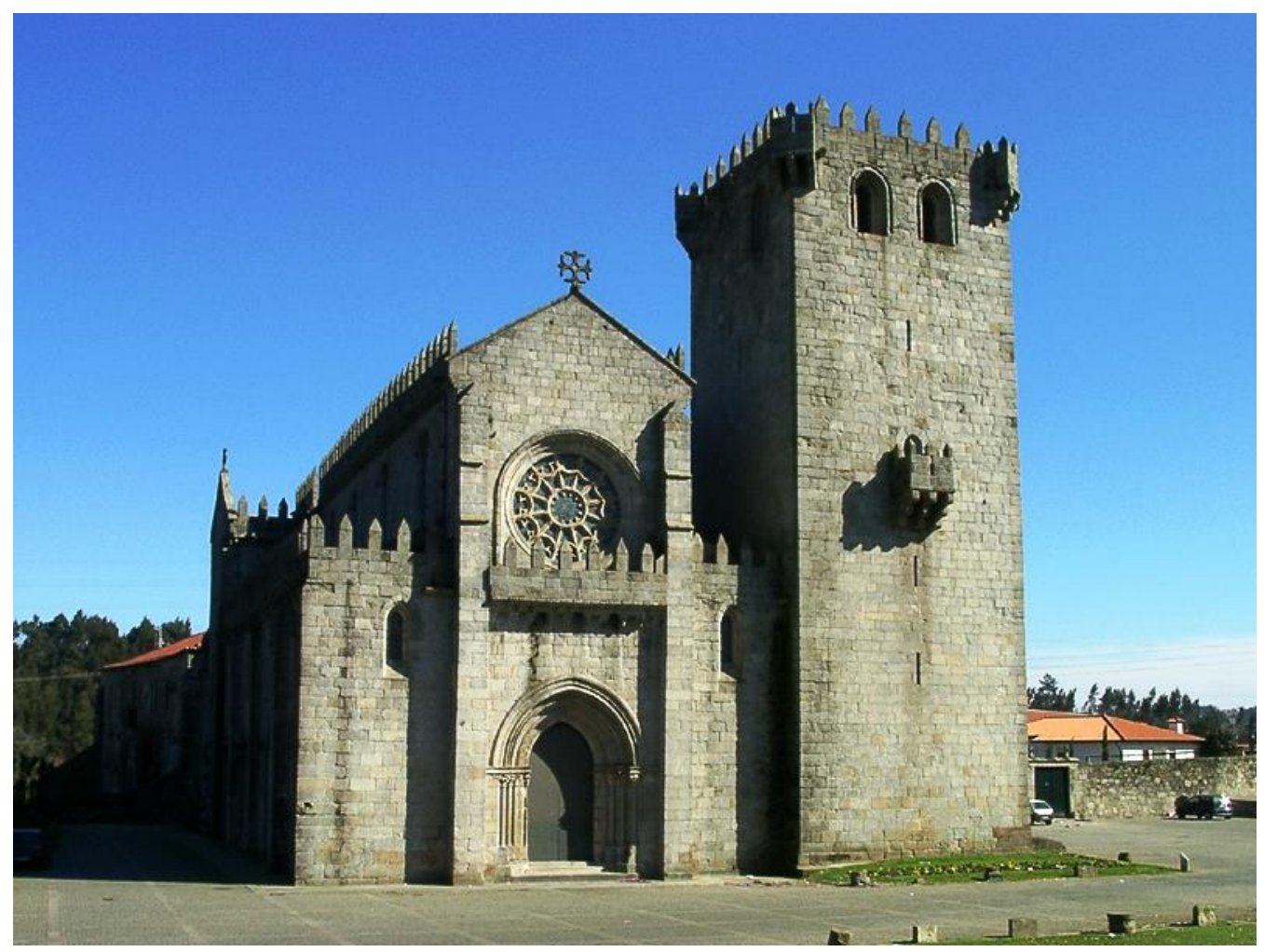

Fonte: SOUSA, Manuel. Mosteiro de Leça do Balio. Disponível em: https://pt.wikipedia.org/wiki/Mosteiro_de_Le\%C3\%A7a_do_Balio. Consultado em: 05 de março de 2015.

Quando a Ordem do Hospital se instalou no espaço português, provavelmente durante o governo de Dona Teresa, privilegiava inicialmente as atividades ligadas à assistência (COSTA, BARROCA, 2009, p. 680). O principal motivo da implantação da Ordem de São João de Jerusalém em Portugal foi a prática da assistência, ficando para segundo plano as intenções militares. Podemos citar, como exemplo, a doação de um hospital que Pedro 
Ourives construíra em Braga, posteriormente confiado pelo Arcebispo Dom João Peculiar aos hospitalários em julho de 1145 (LE ROULX, 1894-1906, pp. 425-429). Em 1147, quando Santarém e Lisboa foram conquistadas por D. Afonso Henriques, não há referência documental que mencione a participação de hospitalários ao lado do exército real, o que nos leva a deduzir que neste momento a Ordem ainda não possuía um programa de ação bélica. Entretanto, em 1189, quando D. Sancho I conquistou os castelos de Alvor e Silves, a participação da Ordem Militar do Hospital já está verificada (COSTA, BARROCA, 2009, p. 680). Nesta ocasião, parece que a Ordem já tinha uma estrutura militar consolidada, que deve ter se desenvolvido na segunda metade do século XII. Citando Mário Jorge Barroca (COSTA, BARROCA, 2009, pp. 680-681), “este aspecto revela que o ramo português dos Cavaleiros de S. João do Hospital tinha procedido a uma reforma da sua orgânica interna, de forma a contemplar as duas vertentes de actuação - a assistencial e a militar".

Apesar da incerteza acerca do momento exato em que os hospitalários se instalaram em Portugal, sabemos que foi no reinado de Afonso Henriques que os Sanjoanistas passaram a ter uma atuação mais significativa no território, como comprova a célebre carta de couto de 1140 (COSTA, 2000, p. 98). Em Portugal, durante a Reconquista, a Ordem do Hospital recebeu comendas em forma de parcelas patrimoniais à medida que as vitórias bélicas aconteciam e novos territórios iam sendo tomados dos muçulmanos.

Em 1140, o rei concedeu carta de couto, sobre Leça, a D. Raimundo (procurador dos santos pobres da Santa Cidade de Jerusalém), a D. Aires (prior de Portugal e da Galiza), aos freires existentes e aos sucessores destes. Este privilégio também abrangia a confirmação de todos os bens que possuíssem ${ }^{42}$. A fonte documental que transcrevemos refere "en como el rey Dom Afonso ha por firmis todalas gaanças e doaçoens que forom feitas ao Spital e couta e confirma o Couto de Leça e quita os vasalos da Ordem de tributo e de servidoem e de coomha e manda que nom paguem portajem" 43.

Além deste registro, há outro no Livro de Herdamentos e Doações de Leça que dispõe o seguinte: "Item carta per que el rey Dom Afonso filho do conde Dom Anrrique couta e confirma todalas herdades e possissoens do Spital. Outrossi manda que os homeens do Spital seyam escusados do tributo e toda servidoem e das portageens. Item couta e confirma o couto de Leça com seus termhos" ${ }^{44}$.

\footnotetext{
42 A.N.T.T., Gaveta VI, maço único, número 29. A.N.T.T., Guadiana, I, 1, fólios 123v-124.

${ }^{43}$ A.N.T.T., Colecção Costa Basto, Livro dos Herdamentos e Doações do Mosteiro de Leça, no 4, fólio 18.

${ }^{44}$ A.N.T.T., Colecção Costa Basto, Livro dos Herdamentos e Doações do Mosteiro de Leça, $\mathrm{n}^{\circ}$ 4, fólio 7.
} 
No trecho acima, observamos que além da confirmação do couto de Leça, há ainda menção da confirmação de todas as herdades e possessões da Ordem do Hospital e uma isenção aos freires da Ordem de terem que pagar tributos (jugada, anúduva, dentre outros), servidões e portagens. Estes privilégios, mais a isenção do exercício de ceder pousada, foram diversas vezes escritos em vários registros do Livro dos Herdamentos e Doações do Mosteiro de Leça e até o reinado de D. Dinis foram privilégios muito recebidos pelos hospitalários e pelos homens que moravam e trabalhavam em suas terras.

Em um primeiro momento, os hospitalários eram possuidores de bens que se localizavam em sua maioria no norte do reino português. Por estar inicialmente instalada no Caminho Português ${ }^{45}$ de peregrinação em direção a Santiago de Compostela, por participar do processo de reconquista territorial e por ajudar no repovoamento e organização social de diversas áreas, a Ordem do Hospital foi receptora, assim como outras ordens militares, da gratidão régia dos primeiros monarcas, que se materializava em doações e privilégios (COSTA, 1997, p. 312).

Além das doações e bens legados em testamentos, a Ordem de São João adquiriu bens por compras ${ }^{46}$ e permutas. As permutas não significaram um título propriamente dito de aquisição patrimonial, pois a instituição teve de oferecer outros bens em troca. "Porém, podemos aceitar que estas propriedades constituíam, de algum modo, um valor acrescentado no plano patrimonial e, por isso mesmo, tinham sido alvo deste tipo de contratos" (COSTA, 2000, pp. 101-102), pois permitia ordenar o patrimônio segundo critérios pré-definidos.

No século XII, o território disponível para partilhar doações era apenas uma parte do que atualmente é Portugal (e era bastante indefinido), o que justifica a localização dos bens

\footnotetext{
${ }^{45}$ O Caminho Português era composto por uma malha viária que alcançava sua parte mais significante no norte de Portugal. A rota principal chegava à Galiza pela cidade de Tui e depois passava por O Porriño, Redondela, Pontesampaio, Pontevedra, Caldas de Reis, Valga e Pontecesures. Outro caminho português, litorâneo, entrava na Galiza por A Guarda e passava pelo mosteiro cisterciense de Oia, passava ainda por Baiona, por Coruxo e por Santo André de Comesaña, onde se bifurcava em duas estradas, a de Coia e Condomiñas e a de Santa María de Castrelos e Santo Tomé de Freixeiro. Depois essas estradas alcançavam Vigo e chegavam a Redondela, onde desembocavam na rota portuguesa principal. Um terceiro caminho era o que atravessava o rio Minho por San Pedro da Torre, local onde se encontravam peregrinos procedentes de Caminha, Arcos de Valdevez e Ponte de Lima. Este caminho, quando entrava em terras galegas, passava pela ponte de Forcadela, por Tebra, por Malvás, pelo monte Aloia, por Cela e por O Porriño, onde os peregrinos tomavam o caminho principal, que já vinha de Portugal (Moreno, 1986, p. 77-90). Para saber mais sobre os Caminhos de Santiago, ler GONZÁLEZ-PAZ, Carlos Andrés. La Orden de San Juan de Jerusalén y las Peregrinaciones en la Galicia Medieval (Siglos XIIXIII). Revista População e Sociedade. Porto: Edições Afrontamento e CEPESE, 2009. ISSN 0873-1861. Nº 17.

${ }^{46}$ Décima Constituição de Afonso II. "A lei citada regulamenta a desamortização dos bens da Igreja, proibindo que as corporações religiosas adquirissem, no futuro, propriedades fundiárias, excepto para aniversário do rei e de seu pai, permitindo a livre compra de bens pelos clérigos, que adentrariam ao seu patrimônio pessoal" (BANHOZ, 2005, p. 62). As compras de patrimônio, feitas pelas instituições eclesiásticas, passaram a ser proibidas no reino de Portugal a partir do reinado de Dom Afonso II. Este autor utilizou documentação publicada no Livro das Leis e Posturas. Lisboa: Faculdade de Direito da Universidade de Lisboa, 1971.
} 
hospitalários no norte, embora se possam apontar outras razões. Naquele século, o destaque maior era a atuação dos hospitalários da comenda de Leça do Balio.

Em nosso entender, uma outra razão, de carácter social, pode ter favorecido a posse de bens patrimoniais na zona norte do reino. Isto é, a proveniência social dos freires de S. João, profundamente relacionada com os estratos nobilitados, os quais estavam fixados sobretudo nesta região, contribuiu para a solidificação de sua presença nestas terras (COSTA, 2000, p. 101).

Imagem 2 - Castelo de Belver.

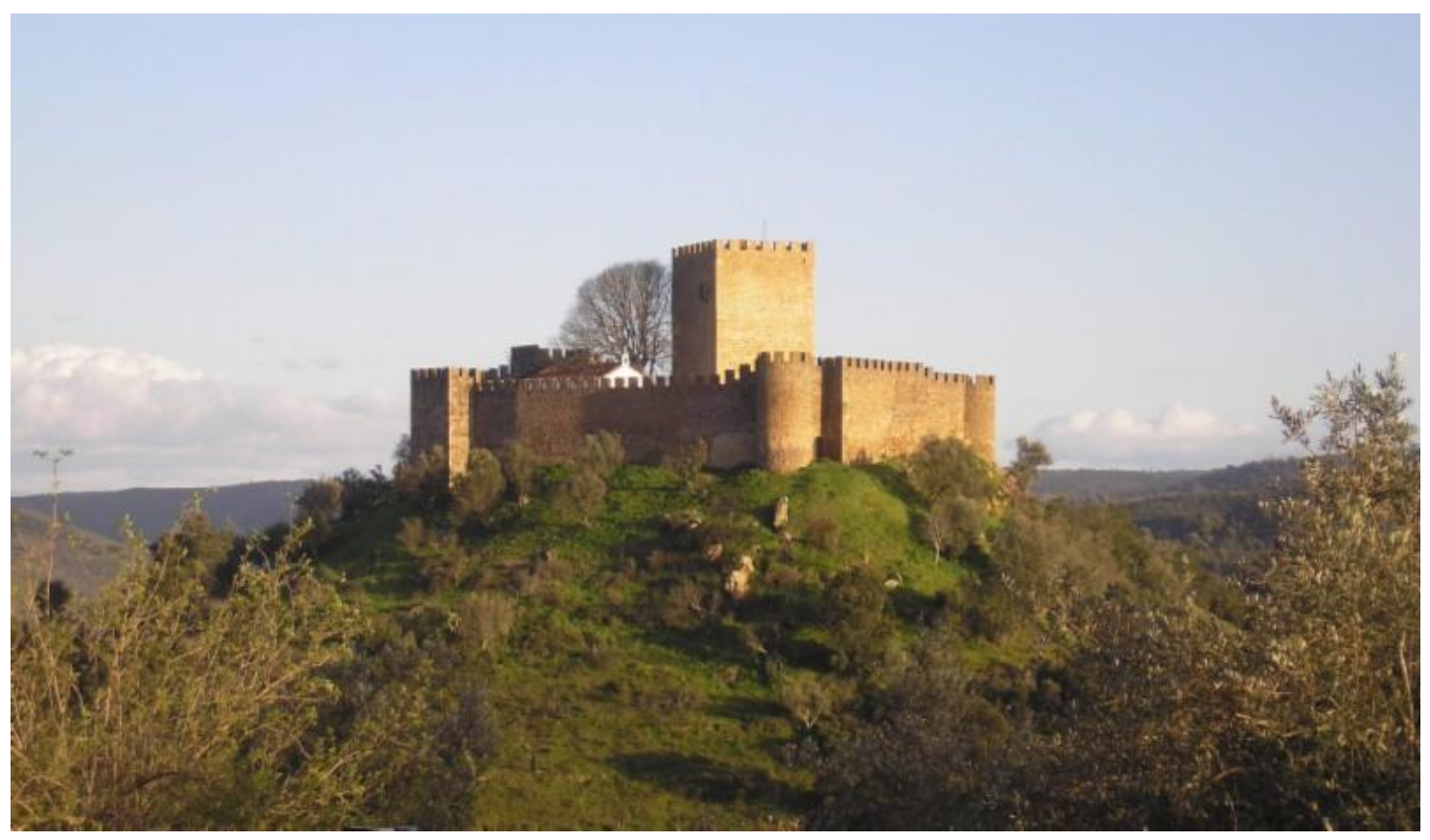

Fonte: SEQUEIRA, Arlindo. Castelo de Belver. Disponível em: http://www.trekearth.com/gallery/Europe/Portugal/South/Portalegre/Gaviao/photo585517.htm. Consultado em: 15 de março de 2015.

No final do século XII, na região da Beira Interior, sugiu um novo núcleo de implantação territorial, localizado inicialmente em torno da terra de Guindimtesta, o atual Gavião/Belver. Foi D. Sancho I que doou à Ordem do Hospital esta terra, em 1194, conforme consta no fólio 8 do Livro dos Herdamentos e Doações do Mosteiro de Leça ${ }^{47}$ "Doaçom que fez el rey Dom Sancho aa Ordem do Spital do Castelo de Belveer com sas divisoens e termhos que son conteúdos na carta que sobre esto deu ao Spital”. Em troca, os freires deveriam construir um castelo (que ficou conhecido como Castelo de Belver), o que demonstra que neste momento, em Portugal, a Ordem já tinha se militarizado, tendo em vista que o castelo deveria cumprir um papel de defesa do que se pensava serem as "fronteiras" do

${ }^{47}$ A.N.T.T., Coleção Costa Basto, no 4, Livro dos Herdamentos e Doações do Mosteiro de Leça, fl. 8. 
reino. A partir deste momento, a Ordem do Hospital se desenvolve na região da Beira Interior e amplia seu domínio senhorial e jurisdicional.

Em 1224, D. Sancho II doa aos hospitalários o castelo de Algoso, doação que se enquadra em uma política de defesa e povoamento regional. Em 1232, D. Sancho II ainda doa à Ordem a região do Crato, esperando que os freires povoassem e protegessem o local ${ }^{48}$. "Item carta d'el rey Dom Sancho per que deu o Crato con seus termhos ao Spital"49. Poucos anos depois, em 1356, a Ordem do Hospital já havia transferido sua sede conventual de Leça para o Crato. Por isso, ao longo dos séculos o Priorado Português da Ordem de São João de Jerusalém foi chamado de "Priorado do Crato"50.

\section{Imagem 3 - Núcleo da Flor da Rosa/Crato.}

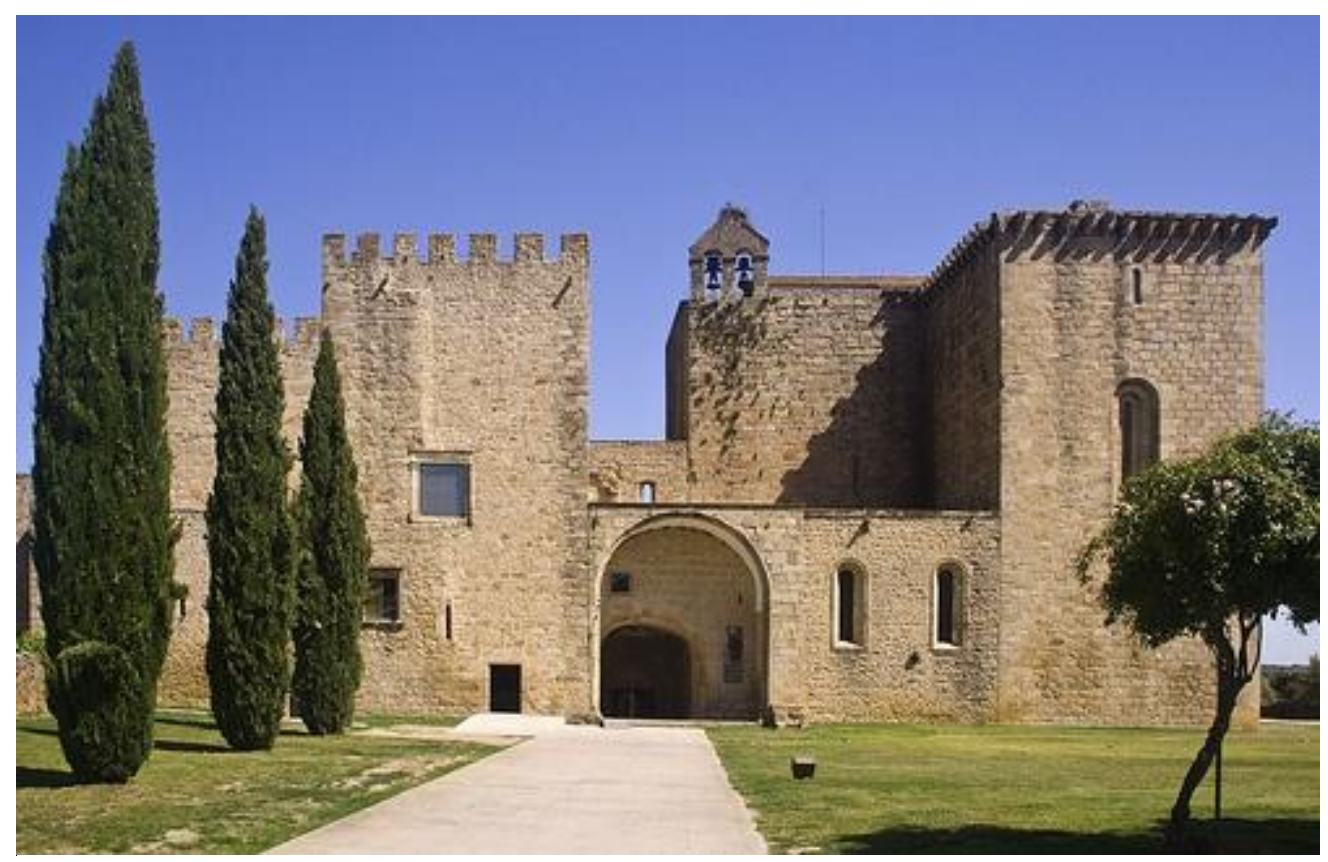

Fonte: BULL, Malcolm. Mosteiro da Flor da Rosa/Crato. Disponível em: https://www.pinterest.com/pin/427842033320014848. Consultado em: 15 de março de 2015.

Verificam-se no Livro dos Herdamentos e Doações do Mosteiro de Leça dois registros que alegam que o Papa Inocêncio III confirmou o castelo de Belver, o tomou em sua guarda e declarou estar esta construção sob proteção papal. "Item privilegio de papa Innocencio terceyro en que toma o castelo de Belveer em sa guarda e em sa encomenda". "Item privilegio

\footnotetext{
${ }^{48}$ A.N.T.T., Gavetas, VI, m. ún., no 22. Pode-se ler no respectivo documento: “...ut faciatis ibi populationem et fortelezam...".

${ }^{49}$ A.N.T.T., Coleção Costa Basto, $n^{\circ}$ 4, Livro dos Herdamentos e Doações do Mosteiro de Leça, fl. 8.

${ }^{50}$ Os documentos citados neste capítulo foram todos consultados durante o tempo em que estivemos em Portugal analisando e providenciando fotocópias e digitalizações de documentos manuscritos, no segundo semestre de 2013. Alguns já haviam sido analisados durante os anos em que cursamos o Mestrado em História Medieval e do Renascimento na Universidade do Porto (2008-2010).
} 
de Innocencio III $^{\circ}$ en que confirma Belveer ao Spital assi como he confirmado pelos reys" 51 . Há ainda, no mesmo códice, um terceiro registro envolvendo Belver, referente a algum Papa Inocêncio (não especifica qual Inocêncio): "Item privilegio de Innocencio papa como filha so sa guarda e defendimento ho castelo de Belveer e deve ende aver en cada huum ano dous dinheiros d'ouro" 52 .

Em 1261, teve lugar o cerceamento de certas atribuições fiscais das ordens presentes no reino português naquele momento, sendo regulamentado o montado, imposto aplicado sobre gado ovino e bovino que pastava em terrenos senhoriais ou concelhios ${ }^{53}$. A partir do século XIV, especificamente no reinado de D. Dinis, as ordens militares passaram a receber interferência da monarquia. Segundo Paula Pinto Costa (2004, p. 146) $)^{54}$ :

No plano concreto das Ordens Militares, as anteriores atitudes de Afonso II e Sancho II, tomadas com o objetivo de controlarem o poder do clero na generalidade, já faziam prever estas mudanças, consubstanciadas num maior controlo exercido junto destas organizações. Esta política, que adquiriu contornos mais seguros ao longo dos reinados seguintes, encontrou um expoente na figura de D. João I, que entregou aos infantes a administração destas instituições.

Após a extinção da Ordem do Templo, no século XIV, foi criada em Portugal a Ordem de Cristo ${ }^{55}$. O Hospital, diferentemente do que foi orientado pela Santa Sé ${ }^{56}$, não herdou o vasto patrimônio templário ${ }^{57}$, que passou quase na totalidade para a nova ordem militar e religiosa portuguesa. O rei português conseguiu do Papa que todo o patrimônio da Ordem do Templo passasse para a pequena ordem militar de Cristo, que era facilmente controlada pela

\footnotetext{
${ }^{51}$ A.N.T.T., Colecção Costa Basto, Livro dos Herdamentos e Doações do Mosteiro de Leça, n 4 , fólios 1 e 3.

${ }^{52}$ A.N.T.T., Colecção Costa Basto, Livro dos Herdamentos e Doações do Mosteiro de Leça, n ${ }^{\circ}$, fólio 17.

${ }^{53}$ A.N.T.T., Chancelaria de D. Afonso III, Liv. 1, fl. 49.

${ }^{54}$ COSTA, Paula Maria de Carvalho Pinto. As Adaptações das Ordens Militares aos Desafios da "Crise" TardoMedieval. Revista da Faculdade de Letras: História. III Série, vol. 5, 2004, p. 146. É preciso indicar a referência por nota de rodapé porque há duas publicações desta autora no ano de 2004.

${ }_{55}$ Bula Ad ea ex quibus, de 14 de março de 1319, pela qual foi fundada a Ordem de Cristo. Publicada em ALMEIDA, Manuel Lopes de [et al.]. Monumenta Henricina. Coimbra: 1960, vol. I, pp. 97-119.

${ }_{56}$ Bula Ad providam, de 12 de maio de 1312, expedida pelo Papa Clemente V. Através desta bula, o Sumo Pontífice atribuiu à Ordem do Hospital os bens templários.

57 "Parece que los monarcas peninsulares se oponían a que la Orden de San Juan ampliase su patrimonio en tal escala. Sabemos que presionaron de tal manera al papa que éste tuvo que retrasar su decisión al respecto. Parece que inicialmente los reyes peninsulares aspiraban a quedarse con los bienes templarios de sus respectivos territorios. Por un lado, el pontificado deseaba incorporar los bienes templarios al Hospital para que siguieran cumpliendo su función de apoyo a la cruzada. Por el otro, los reyes peninsulares querían crear con ellos pequeñas órdenes militares en sus dominios estrechamente ligadas a la monarquia. La solución va a oscilar gradualmente en cada reino entre ambas as posturas. De esta forma, el caso portugués constituye el ejemplo más claro de victoria de la posición contraria a una incorporación del patrimonio templario al Hospital, que tan general era entre las monarquías ibéricas" (BARQUERO GOÑI, 2003, pp. 36-37).
} 
monarquia. Este fato comprova que já havia se consolidado certa animosidade entre a Ordem e a Coroa, a qual teria tido início no reinado de D. Afonso III.

Apesar de a Ordem do Hospital não ter herdado a base patrimonial pertencente aos Templários, verifica-se em documentações distintas que houve algumas transmissões de propriedades entre essas ordens, cujos processos desconhecemos (COSTA, 2000, p. 191). Um exemplo disso é Bemposta, antigo patrimônio templário que foi motivo de conflito entre o Hospital e o concelho do respectivo lugar. Para resolver esta questão, D. Dinis reconheceu as pretensões dos freires e decretou que as delimitações do lugar estavam corretas ${ }^{58}$.

Os hospitalários desenvolveram essencialmente quatro tipos de atividades no Reino de Portugal: os freires, além de praticarem atividades de assistência e hospitalidade, ainda exerceram funções militares frente à ameaça muçulmana e contra outros monarcas cristãos. Sabemos também que a Ordem do Hospital atuou em vários repovoamentos e reorganizações territoriais e que tinha como um dos principais deveres o envio de recursos e reforços ao Convento Central da Ordem no Mediterrâneo oriental.

Após o fim da Reconquista em Portugal, os monarcas começaram a impor regras que norteariam a operacionalidade das ordens militares. Em muitas ocasiões, a monarquia tentou usar as ordens militares em benefício próprio (COSTA, 2012, p. 7).

\begin{abstract}
As Ordens Militares têm muito patrimônio, exercem prerrogativas jurisdicionais civis e religiosas relevantes e desempenham um papel diplomático crucial em proveito da monarquia, decorrentes do seu prestígio e dimensão internacional. Com efeito, estas circunstâncias (patrimoniais, jurisdicionais e diplomáticas) tornam obrigatória a sua observação constante e o controlo por parte da monarquia, de forma a garantir a convergência de interesses (COSTA, 2012, pp.16-24).
\end{abstract}

A primeira tentativa de sistematizar uma reorganização na atuação das ordens militares foi de D. Dinis (1279-1325), que criou a Ordem de Cristo após a extinção da Ordem do Templo, que lutou pela independência da Ordem de Santiago face ao seu Convento Central, Uclés, e disciplinou a Ordem de Avis e do Hospital, procurando libertá-las da tutela dos respectivos conventos estrangeiros. Depois, no reinado de D. João I, os filhos do rei passaram a ser designados para a administração das Ordens de Santiago (1418), de Cristo (1420) e de Avis (1434), sendo os infantes designados de administradores ou governadores.

D. João II, quando assume o reino, implantou iniciativas destinadas ao reforço da autoridade régia, em uma tentativa de se sobrepor às aristocracias (MATTOSO, 1997, pp.

${ }^{58}$ A.N.T.T., Chancelaria de Dom Dinis, Liv. 1, fl. 124. 
437-443). Essa política se reflete na maneira como o monarca se relacionava com as ordens militares. Com relação à Ordem do Hospital, D. João II cerceou alguns privilégios e limitou a área de influência da milícia (VASCONCELOS, 2008, p.117).

Já D. Manuel I passa a acumular o título de rei com o de mestre da Ordem de Cristo (mestre desde 1484 e rei desde 1495). Com relação à Ordem do Hospital, D. Manuel interfere diretamente na escolha do Prior do Crato, fazendo com que D. João de Meneses fosse nomeado Prior, com a aprovação do Papa. Mais tarde, a partir de 1532, a Ordem do Hospital passou, também, a ser controlada enfaticamente por um mecanismo semelhante; a entrega do Priorado do Crato aos infantes, sendo o primeiro deles D. Luís, filho de D. João III.

D. João III, durante seu reinado, cria a Mesa da Consciência e Ordens (1532), que impunha uma espécie de programa de submissão à política régia (COSTA, 2012, pp. 16-24). Em 30 de dezembro de 1551, D. João III anexa perpetuamente os Mestrados de Avis, Cristo e Santiago à Coroa através da bula papal Praeclara carissimi. Resumindo, a partir do século $\mathrm{XV}$, a monarquia portuguesa, à semelhança do que acontecera em Castela, se esforçara por controlar estas instituições.

A Ordem do Hospital diferenciava-se das restantes em dois grandes aspectos. De um lado, por uma autonomia institucional específica enquanto Ordem de atuação intercontinental, cujos diferentes ramos, as Línguas ${ }^{59}$, estavam diretamente dependentes do Convento Central sediado em Malta; consequentemente, sujeitos à autoridade de um Mestre Geral e às diretrizes assumidas em Capítulos Gerais. Por outro lado, o fato de ser uma Ordem que além de funções bélicas, exercia funções caritativas e cujos seus membros cumpriam efetivamente os votos de castidade, pobreza e obediência (VERSOS, 1997, p.110).

$\mathrm{Na}$ Ordem de Malta, manteve-se o voto de castidade dos seus cavaleiros e a exigência de fidalguia nas suas habilitações até ao século XIX, diferentemente das demais ordens militares portuguesas. Tratando-se de uma organização de vasta atuação, a monarquia portuguesa procurou, também, controlar estes cavaleiros. Foi elaborada uma política semelhante à desenvolvida em torno das Ordens de Avis, Cristo e Santiago nos séculos XV e XVI. Tentou-se reservar o lugar de Prior do Crato para os filhos e parentes da Coroa, legítimos ou bastardos. A ligação da Ordem de Malta à Coroa ocorreu, porém, tardiamente. "Desde 1675, e após uma longa contenda travada com a Santa Sé, tornara-se regra a nomeação de infantes para o cargo de Grão-Prior" (VERSOS, 1997, p.115).

\footnotetext{
${ }^{59}$ No caso de Portugal trata-se da "Língua de Castela e Portugal", e nesta o Priorado do Crato.
} 
Apenas em 1789 o Grão-Priorado de Portugal é, a pedido da rainha e por bula papal, separado da soberania da Ordem de Malta, iniciando um processo que somente viria a terminar em 1793, no decorrer do qual seu patrimônio foi anexado à Casa do Infantado, à semelhança do que acontecera na Espanha, onde, por determinação de Carlos III, o Priorado de Castela e Leão foi perpetuamente concedido por Pio VI, em 1784, ao Infante D. Gabriel e seus descendentes. Em 1834, o Priorado de Portugal, um dos seis priorados que ainda restavam à Ordem, é definitivamente extinto, juntamente com a Casa do Infantado, na qual era incorporado (FONSECA, 2002).

\subsection{O SURGIMENTO DO PRIORADO DO CRATO}

Já discutimos, anteriormente, a instalação da Ordem do Hospital de São João de Jerusalém em Portugal. Entretanto, não aprofundamos a discussão acerca do surgimento do Priorado do Crato, denominação que o Priorado de Portugal da Ordem do Hospital passa a ter após 1340, quando o novo mosteiro começa a ser construído no Crato. No ano seguinte, inicia-se nas proximidades do mosteiro a construção da Capela da Flor da Rosa, uma igrejafortaleza em homenagem à Santa Maria, o que significava que a Ordem pretendia continuar afirmando sua identidade através das armas e também visava a continuidade do serviço caritativo de ajuda aos pobres e peregrinos.

De acordo com Paula Pinto Costa (2010, p. 58),

Neste sentido, podemos afirmar que há uma intenção de centralizar no espaço da Flor da Rosa os princípios que sempre nortearam a identidade e a acção da Ordem, procurando-se uma espécie de refundação, em detrimento de Leça do Balio, que, no século XIV, estava afastada da nova centralidade que o reino encontrara mais a Sul.

Quando estudamos a mudança de sede da Ordem do Hospital em Portugal de Leça do Balio para Flor da Rosa/Crato, vem-nos à mente as seguintes perguntas que como historiadores devemos-nos fazer: I) Por que houve essa transferência de sede? II) Quem foi ou quais foram os responsáveis pela transferência? III) Por qual ou quais motivos isso ocorreu? VI) Quais as consequências disso para a Ordem, para a Coroa, para a nobreza e para a população local? 
Para comerçarmos a responder a todas essas questões, é preciso remontar à década de setenta do século XIII, especificamente a 02 de abril de 1271, quando D. João Peres de Aboim e sua mulher D. ${ }^{a}$ Maria Afonso, concederam à Ordem do Hospital o padroado da Igreja de Santa Maria de Portel, bem como de todas as igrejas de seu termo. D. João Peres de Aboim, uma das personalidades mais importantes da Corte e mordomo-mor de Portugal, era senhor de Portel desde que o rei D. Afonso III havia exigido ao Concelho de Évora que lhe cedesse um conjunto de terras, em novembro de 1258 (COSTA, 2013, p. 207), como forma de reformar estruturas de domínio régio sobre tal região.

D. João de Aboim também recebera, em 13 de janeiro de 1262, do bispo e cabido de Évora a jurisdição das igrejas que estavam situadas em suas terras, das quais era padroeiro, sendo uma delas a Igreja de Santa Maria de Portel, mencionada acima. Juntamente com a Igreja de Santa Maria de Portel, havia sido concedido aos hospitalários o padroado das igrejas do Crato, da Amieira e de Portel, "sem qualquer elemento que as discrimine, porque estes freires faziam continuadamente guerra aos infiéis" (ALMEIDA, 1971: IV, 137 apud COSTA, 2013, p. 209).

A partir de 1271, de acordo com imposições do documento que menciona a concessão do padroado das igrejas de D. João de Aboim à Ordem do Hospital, a Igreja de Santa Maria de Portel, assim como as demais do seu termo, seriam mantidas pelo mosteiro de Marmelar ${ }^{60}$, que deveria passar a ser uma bailiagem e residência do comendador e dos freires, com exceção daqueles que prestavam serviços nas igrejas. Aos comendadores e freires ficava vedado negociar outros bens em Portel e termo para além dos padroados das ditas igrejas, sendo que o patrimônio dos novos freires ou confreires, clérigos ou leigos, deveria ficar para os senhores de Portel ou serem vendidos no prazo de um ano. Apenas bens móveis poderiam ser recebidos por aqueles hospitalários. O documento ainda previa outras obrigações à Igreja de Santa Maria de Portel e das outras igrejas do termo, como por exemplo, pagar aos senhores de Portel e aos seus herdeiros, anualmente no mês de maio, 100 libras em moeda corrente, cuja destinação seria a guarda do castelo de Portel, por estar em região de fronteira.

Paula Pinto Costa lista ainda outras obrigações impostas pelo documento acima citado à Igreja de Santa Maria de Portel, a partir daquele momento mantida pelos hospitalários (COSTA, 2013, pp.210-211):

\footnotetext{
${ }^{60}$ Portel e Vera Cruz de Marmelar, na Idade Média estavam no Alto Alentejo. Atuamente, fazem parte do Distrito de Évora, região do Alentejo Central, a 145 e 157 quilômetros a Sul da Vila do Crato (atual Distrito de Portalegre), respectivamente.
} 
O prior do mosteiro de Marmelar e os comendadores deveriam ser homens bons, he nossos amigos e amem nos santamente, e guardem a nos, e a todos os que depos nos vierem, e nosso castello, e todolas nossas cousas bem e verdadeiramente, e excelentemente; caso o comendador não respeitasse este código de conduta, a Ordem deveria substituir o comendador;

Porque se tratava de um lugar que he novo, só depois da morte de Afonso Peres Farinha, o mosteiro teria que pagar anualmente de responsão ao Ultramar 200 maravedis da moeda corrente, mas só depois de pagas as referidas 100 libras aos senhores de Portel, as vestimentas dos freires, as soldadas aos servos do mosteiro, a lavra das terras e todas as dívidas; caso esses 200 maravedis não fossem enviados, seriam aplicados em benfeitorias do mosteiro;

O Grão Comendador ou o prior da Ordem em Portugal quando visitassem o mosteiro receberiam os seus ovos duas vezes no ano e não poderiam demandar o comendador do mosteiro de Marmelar;

O mosteiro de Marmelar com todos os seus termos foi constituído pelo herdamento que D. João de Aboim tinha em Beja, pelo padroado de Santa Maria com todas as outras igrejas de Portel e seu termo, por 100 vacas, 1000 ovelhas, 100 porcos, 100 colmeas, 12 égoas, 1 cavalo, 200 moios de pão, 3000 libras em dinheiro, 12 livros muito bons, 3 pares de muito boas vestimentas, 3 cálices muito bons de prata; estes bens foram doados para a fundação do mosteiro; o senhor de Portel dá-se por quite de metade dos frutos da Igreja de Santa Maria de Portel, bem como das outras, pois trata-se de uma terra de fronteira de Mouros e de Cristãos, he lugar de gram guerra, e de gram custa;

D. João de Aboim apresenta motivações religiosas, acrescentando que é confreire do Hospital, que recebe benefícios da Ordem e de Afonso Peres Farinha, o qual, por seu mandado, fundou o mosteiro.

Com relação ao que fora doado por D. João de Aboim aos hospitalários, em nenhum momento consta o Santo Lenho e nem a cruz processional, sobre o quê falaremos mais adiante. As doações do senhor Aboim representam tanto um apelo religioso quanto militar à Ordem do Hospital ${ }^{61}$, e só aconteceram talvez porque o Hospital fosse uma instituição intercontinental e não dependesse muito da monarquia castelhana, como as demais ordens ibéricas, a citar, Santiago e Avis, filiadas à Uclés e Calatrava, que já possuíam muitos territórios no Alto Alentejo. Além disso, apesar de a Ordem do Hospital possuir poucas comendas na região, já tinha experiência naqueles campos de batalha do Sul de Portugal, afinal o comendador do novo mosteiro de Marmelar, D. Afonso Peres Farinha, havia morado durante duas décadas em Moura e Serpa, no limite fronteiriço, antes de ir viver em Marmelar.

Analisando Portel e Marmelar na segunda metade do século XIII, verificamos que o poder estava nas mãos de personagens do ambiente régio e que ambos eram membros de uma

${ }^{61}$ Nesta questão discordamos de Paula Pinto Costa (2013, p. 211), que chega a afirmar que as doações à Ordem do Hospital representavam mais um apelo religioso do que militar ou à sua capacidade de gestão dominial, pois, segundo esta autora, há que se levar em conta a inexperiência dos hospitários portugueses em ocupar e proteger terras fronteiriças na região do Alto Alentejo. Ora, a liderança dos hospitalários locais estava nas mãos do Frei Afonso Peres Farinha, que já tinha vivido cerca de vinte anos em Moura e Serpa, regiões ainda mais ao Sul de Marmelar. 
nobreza instalada no Norte de Portugal: João Peres de Aboim vinha da Nóbrega e Afonso Peres Farinha vinha de Farinha Podre, Penela. João de Aboim, mordomo-mor do reino (1264), homem de confiança do rei, senhor de Portel e confreire da Ordem do Hospital. E Afonso Farinha, conselheiro régio (1250-1279), testamenteiro de D. Afonso III (1271), corregedor dos feitos do reino (1279), comendador de Marmelar, Prior da Ordem em Portugal (a partir de 1261), e com vinte anos de experiência em terras de fronteira (COSTA, 2013, p. 212). Ambos eram homens da confiança do rei, com relevantes funções desempenhadas ao longo da vida, distribuíam o poder local entre si desde então, promovendo organização social, política e eclesiástica, exploração econômica, serviços caritativos e proteção militar à região de Portel e Marmelar.

Vale ressaltar que a comenda de Marmelar ganhou imensa importância dentro da Ordem do Hospital a partir do momento em que a relíquia do Santo Lenho (suposto fragmento da Cruz de Cristo) fora associada à história do próprio freire D. Afonso Peres Farinha, a quem a historiografia do século XIX e início do XX relacionava com a chegada da relíquia à região. Guardar e proteger uma relíquia da Santa Cruz propiciou grande importância à Ordem do Hospital no Alto Alentejo, pois gerava forte perfil devocional.

Afinal, qual foi o momento da incorporação desta relíquia no patrimônio da Igreja de Marmelar? De acordo com Paula Pinto Costa (2013, p. 216),

Trazida, segundo a tradição, por frei Afonso Peres Farinha numa das suas três missões ao Ultramar, foi aqui depositada por razões que a história não conservou de forma linear. Apesar de a ideia de que tal feito se ficou a dever a Afonso Farinha ter sido repetida em diversas obras, não se encontra evidência documental coeva que a sustente. $\mathrm{O}$ primeiro texto que alude à presença da relíquia em Marmelar é o testamento de D. Dinis, que nada esclarece sobre o seu percurso prévio. Assim, há que ter em conta de que não há prova documental coeva de que tenha sido frei Farinha o portador. É de aceitar como altamente provável que se tivesse sido ele autor desta proeza, a sua lápide funerária o referisse, facto que não se verifica. Segundo palavras escritas nos anos 80 do século XIV no Livro de Linhagens do Conde D. Pedro, o prior Hospitalário Álvaro Gonçalves Pereira com três outros cavaleiros forom com el na busca da Vera Cruz, o sentido destas palavras é dúbio e, por isso, não é claro se foram a Marmelar buscar a relíquia, ou se foram a um outro qualquer sítio.

De fato, a própria lápide de Afonso Peres Farinha, existente na Igreja de Vera Cruz de Marmelar, não menciosa o Santo Lenho, o que seria demasiado incoerente se ao tempo em que a lápide fora escrita já existisse alguma ligação entre tal comendador e a relíquia. Vale lembrar que Afonso Farinha faleceu em 1282 e que a lápide indica que o freire provalvemente 
já havia iniciado a construção do mosteiro por volta de 1268/1271?, ou seja, mesmo antes da dotação de 1271, ano em que, então, passou a ser comendador. Provavelmente, quando a lápide fora escrita ainda não era atribuída a D. Afonso Farinha a chegada do Santo Lenho à Marmelar. Além disso, no testamento de D. Dinis (de 1322), nas instruções de devolução da relíquia da Vera Cruz ao cenóbio, não há esclarecimento sobre o percurso prévio do Santo Lenho.

Ainda de acordo com Paula Pinto Costa, há duas notícias da ida do Santo Lenho para Vera Cruz, datadas do século XVII. Há uma referência nos Tombos das Comendas da Ordem de Malta, "onde, no contexto da batalha do Salado, se faz uma referência à relíquia que oje em dia se guarda com gramde veneração na see de Evora, e a outra parte se pos em huma igreya da Invocação da Sancta Crus que esta junto a Portel” (FONSECA, 2013, doc. 82). Outra referência à relíquia está relatada no Agiologio Lusitano, "que diz que a relíquia foi trazida por Afonso Farinha, que se destinava à Sé de Évora, embora por razões milagrosas tenha permanecido em Marmelar, e faz a associação da mesma à Batalha do Salado"62 (CARDOSO, 1666: fl.55r apud COSTA, 2013, p. 216). Juntamente com essa segunda referência, estava a explicação de que depois de finalizada a Batalha do Salado, D. Afonso IV mandara partir ao meio o fragmento e que metade fosse guardado na Sé de Évora e a outra metade guardada na Igreja de Vera Cruz de Marmelar, sendo esta segunda metade posteriormente adornada de prata por D. Nuno Álvares Pereira, que também nela mandara esculpir suas armas.

Outra questão intrigante é pensarmos que se realmente tivesse sido Afonso Peres Farinha quem levou a relíquia a Portugal quando voltava de uma de suas viagens ao Ultramar, por que não a guardou em Leça do Balio, mosteiro que apesar de ser ainda pequeno naquele momento estava em uma região mais segura, distante das fronteiras e no caminho de peregrinação à Santiago de Compostela? Ou, por que não a manteve em Belver, cujo castelo era novo, imponente e representava a força militar dos hospitalários em Portugal? Ou ainda por que não a levou para o Crato, onde já havia um castelo em 1232 e onde, segundo a carta de doação de D. Sancho II $^{63}$, a Ordem do Hospital devia povoar e fortalecer?

\footnotetext{
${ }^{62}$ A Batalha do Salado foi o conflito envolvendo cristãos (Portugal e Castela) e Mouros (Granada e Marrocos), que resultou no enfrentamento de 30 de outubro de 1340, quando Castela de Afonso XI e Portugal de Afonso IV se unem e vencem os muçulmanos. Em 1339, Granada tomou Gibraltar e assolou os territórios cristãos do Sul. Em 1340 foi o rei de Marrocos que atravessou o estreito com mais de 100 navios e adentrou a Península Ibérica, onde se aliou aos Granadinos para prosseguir ao Norte. As crônicas medievais perpetuaram a vitória cristã como uma das maiores de toda a Reconquista. O Reino de Granada ainda perdurou durante um século e meio até ser definitivamente conquistado pela Espanha. Nota nossa.

${ }^{63}$ A.N.T.T., Gavetas, VI, m. ún., n 22. Pode-se ler no respectivo documento: “...ut faciatis ibi populationem et fortelezam...".
} 
A resposta pode ser óbvia ou completamente desconhecida, ainda mais quando as lendas tentam deturpar a realidade, por mais inalcançável que essa realidade seja. O que se nota é que a documentação afirma que o primeiro destino da relíquia era a Sé de Évora, e que, por outros motivos parte da relíquia fora parar em Marmelar. Ora, se supostamente D. Afonso Farinha buscou a relíquia no Ultramar, nada mais justo que guardá-la, pelo menos parcialmente, na Igreja de Marmelar, que estava sob os cuidados da Ordem do Hospital, e que fazia parte da Comenda Hospitalária de Marmelar. Além disso, havia uma imensa proximidade do Prior do Hospital com o senhor de Portel, o que seria mais uma força de atração para a relíquia na região de Marmelar. Até mesmo poderia ter sido guardada em Marmelar como uma homenagem póstuma ao Comendador Afonso Farinha ou à própria Ordem. Por fim, há ainda uma motivação bastante forte para se levar parte da relíquia para Marmelar: a região se relacionava com o ideal de Cruzada (talvez por ainda possuir elementos culturais e de memória da época visigótica).

Entretanto, precisamos nos lembrar de que nas lápides de D. Afonso Peres Farinha, falecido em 1282, não há menção à relíquia do Santo Lenho. Também não há menção à relíquia no documento de 2 de abril de 1271, pelo qual os senhores de Portel concederam à Ordem de São João o direito de padroado na Igreja de Santa Maria de Portel, bem como nas do termo. Diante disso, é provável também que o Santo Lenho possa ter sido levado à Marmelar por outra pessoa, depois da morte de D. João de Aboim e de D. Afonso Peres Farinha ou que já estivesse mesmo em Marmelar antes da chegada de ambos à região. O que é evidente é que dificilmente a relíquia teria sido omitida nas lápides, caso tivesse ligação com tal Prior do Hospital (COSTA, 2013, p. 217).

O que é certo é que não se sabe com precisão quando e como a relíquia do Santo Lenho chegou à Marmelar. Pairam ainda dúvidas e lendas na historiografia e na documentação. O primeiro documento que menciosa o mosteiro de Marmelar como sendo da invocação de Vera Cruz é de 5 de maio de 1397 (FONSECA, 2103, doc. 17).

Segundo Paula Pinto Costa (2013, p. 218):

Assim, terá sido entre 1328 e 1397 que ocorreu a alteração do orago de S. Pedro para Vera Cruz, por hipótese em concomitância com a criação da paróquia em 1345. Face a esta constatação, somos de opinião que o facto que a pode ter justificado foi a batalha do Salado, precisamente o episódio que revigorou a história da comenda, como se de uma refundação se tratasse.

Com a vinculação da Comenda de Marmelar à Batalha do Salado e à relíquia do Santo Lenho, foi criada uma nova memória social acerca da importância histórica da região, tanto 
para a história de Portugal quanto para a história religiosa do Cristianismo, o que aumentou a atração de peregrinos e de olhares régios para o mosteiro, para os hospitalários de Marmelar e principalmente, favoreceu um aumento de prestígio para as famílias nobres que detinham poder político, jurisdicional e religioso na região.

As principais famílias nobres instaladas em Portel e Marmelar eram os Pereira e os Góis-Farinha. Os primeiros ligados à memória vitoriosa da Batalha do Salado, os segundos ligados ao senhorio de Portel. Os Pereira eram ainda bastante vinculados à Ordem do Hospital, que congregava vários de seus membros.

Vale ressaltar que depois da Batalha do Salado, surgiu um discurso régio legitimador baseado na ideia de Cruzada, o que de certa maneira propicia uma evolução da situação econômica da comenda na segunda metade do século XIV. Os monarcas passam a incentivar com diversos tipos de privilégios a fixação de pessoas na região de Marmelar, principalmente concedendo terras em sesmarias e promovendo feiras locais. Havia ainda, para quem lá fosse morar e povoar: isenção de peitas, fintas, talhas, pedidos, empréstimos e encargos concelhios em todo o reino.

De acordo com COSTA, 2013, p 220:

Estariam dispensados de ter cavalos, armas, velar, roldar, ir com presos ou com dinheiros, servir em frontarias, servir nas anúduvas da vila de Viana do Alentejo e das terças que o Rei mandara fazer na comarca de Entre Tejo e Guadiana. Ninguém lhes poderia tomar pão, vinho, roupa, palha, lenha, galinhas, gados e bestas. Dados os motivos devocionais evocados pelo Rei, deve sublinhar-se o prestígio da relíquia já nessa altura, o que pode ter contribuído par a amplitude da concessão régia. Por sua vez, esta ação pode ter sido reforçada pela conjuntura política do momento, em que a ameaça castelhana faz destes territórios associados à fronteira e às Ordens Militares pontos muito importantes, a par da influência dos Pereira na corte de D. João I e dos de Góis no contexto desta comenda. Enquanto os Pereira são associados à Vera Cruz no âmbito da memória do Salado, os de Góis estão ligados à história da comenda desde que ela foi constituída no quadro do senhorio de Portel.

D. Joao I, ao solicitar que os hospitalários escolhessem novo Prior, a escolha recaiu em Lourenço Esteves de Góis, comendador de Marmelar. Os de Góis do século XV, descendentes dos Góis-Farinha do século anterior, mantinham tamanha proximidade com a monarquia, que esse vínculo se materializava em doações e privilégios à Ordem do Hospital e aos seus homens, como por exemplo, a doação vitalícia que D. Afonso V faz em 2 de julho de 1450 a frei Pedro de Góis, comendador de Vera Cruz, "da vila de Lousã com o seu castelo e 
jurisdição cível e crime, mero e misto império, reservando para o Rei apenas a correição, alçada e confirmação dos tabeliães" (FONSECA, 2013, doc. 31).

No século XV havia grande preocupação régia em povoar essa região, considerada fragilizada pela proximidade da fronteira. Havia uma significativa escassez demográfica, o que causava pouco rendimento agrícola, que era compensado pelos rendimentos vindos das esmolas e da nova feira de Vera de Cruz. Por isso a preocupação dos reis em povoar a região oferecendo tantos privilégios. Em 24 de agosto de 1463, por exemplo, D. Afonso V chegou a autorizar a concessão de bens da Ordem em sesmarias, afinal, o comendador frei Pedro de Goiás afirmava que havia muitas terras, casas, pardieiros, vinhas, herdades e bens não aproveitados, que poderiam se perder por não haver quem os explorasse, provocando assim prejuízos aos rei e à comenda (FONSECA, 2013c, doc. 37 apud COSTA, 2013, p. 222) ${ }^{64}$.

Vale ressaltar que na comenda de Marmelar produzia-se trigo, cevada e gado. Além disso, havia outros rendimentos, que aumentavam à medida em que a região se tornava mais prestigiada. Veja como Paula Pinto Costa (2013, pp. 222-223) se refere quanto à isso:

Ao nível do setor do setor primário destaca-se a produção de trigo e de
cevada, de acordo com as memórias paroquiais. No âmbito das atividades
económicas, o gado era também importante, como sugere a localização da
comenda e o facto de, em 8 de agosto de 1488 , D. João II ter concedido uma
renda de 20 mil reais a João Carreiro, escudeiro da casa real e morador em
Vera Cruz, por ter passado gado e dado guarida aos passadores. Para além da
atividade agro-pastoril, a comenda de Marmelar tinha interesses comerciais,
sobretudo em torno da feira, que gerava rendimentos atrativos. Um indicador
disto mesmo é o facto de, em 26 de agosto de 1425 , D. João I conceder a
Catarina de Sousa, entre outras coisas, a sisa que os judeus pagavam na feira
de Vera Cruz, em compensação de não lhe ter dado quatro mil coroas de
ouro, por não ter o referido montante de ouro disponível, que lhe prometera
por ter casado com o meirinho-mor. Desta informação resultam duas
observações. Em primeiro lugar, a importância da sisa paga pelos judeus que
frequentavam a feira de Marmelar; em segundo, esta terra, mais uma vez,
aparece associada a figuras proeminentes da corte régia (v.g. o meirinho-
mor).

Já no século XVI, a comenda apresenta-se bastante prestigiosa, sendo entregue sempre a cavaleiros de elevada condição hierárquica dentro da Ordem do Hospital, como por exemplo, os casos dos cavaleiros Lourenço Esteves de Góis, que de comendador ascendeu a

\footnotetext{
${ }^{64}$ De acordo com esta autora: "Neste seguimento, em 8 de fevereiro de 1471, D. Afonso V autoriza frei Fernão Correia, comendador de Vera Cruz, a conceder terras em sesmarias, desde que as pessoas leigas e submetidas à jurisdição régia, de forma a evitar o avolumar de propriedades na mão da Igreja, nomeadamente sob a tutela das Ordens Militares. Este assunto foi de novo abordado em 18 de julho de 1473, altura em que o Rei autoriza o comendador a conceder terras em sesmarias" (COSTA, 2013, p.222).
} 
Prior de Portugal, e André do Amaral, que foi comendador em Marmelar, Chaceler-mor de Rodes e Conservador Geral da Ordem (FONSECA, 2013, docs. 18 e 59) ${ }^{65}$.

A entrega de uma comenda com tamanho prestígio a um determinador prior, poderia ser fator determinante para que este cavaleiro alcançasse a liderança da Ordem através da eleição ao cargo de prior. Além disso, para se receber as principais comendas ou bailias, tais cavaleiros já vinham de círculos de poder régio e de famílias nobres, ligadas ou não à região da comenda que recebia. O que importa é percebermos que o destino da Ordem em Portugal estava ligado a tais priores, cujos interesses quase sempre coincidiam com os interesses régios, ou pelo menos pareciam coincidir, na medida em que esses eram, muitas vezes, indicados ou apoiados pelos monarcas em épocas de eleição para o Priorado.

Até agora discorremos sobre a Comenda de Marmelar e sobre a presença da relíquia do Santo Lenho na Igreja de Vera Cruz, mas ainda não explicamos o que isso tem a ver com a Comenda de Flor da Rosa/Crato. Neste ponto a história das duas comendas começa a se cruzar, e se cruzam exatamente por causa da importância do Santo Lenho no imaginário português, formado a partir da Batalha do Salado.

De acordo com o que analisamos anteriormente, sabe-se que após a Batalha do Salado parte da relíquia fora levada à Sé de Évora e parte fora mantida na Igreja de (Vera Cruz de) Marmelar. Para chegarmos à compreensão sobre como a Comenda da Flor da Rosa ganha importância nesse contexto, precisamos retornar à lenda criada sobre a Batalha do Salado.

Segundo um manuscrito do Livro de Linhagens do Conde D. Pedro (PEDRO, 1340), o fragmento da Santa Cruz teria sido transportado até o campo de batalha pelo Prior do Hospital D. Álvaro Gonçalves Pereira, a pedido do rei D. Afonso IV. Este Prior mandou colocar a relíquia numa cruz de haste elevada para garantir a visibilidade. Esta cruz supostamente desaparece e depois é recuperada por um cavaleiro e três de seus vassalos. Segundo a narrativa, a Vera Cruz serviu como elemento de motivação aos cavaleiros, possibilitando a vitória cristã frente ao Islã. Após a Batalha, o Prior do Crato tinha tanto prestígio que acabou sendo considerado aquele que recuperou a relíquia desaparecida, utilizando-a para vencer os mouros. De acordo com o Livro de Linhagens do Conde D. Pedro, os guardiães do Santo Lenho eram os Pereira, família liderada pelo Prior Álvaro Gonçalves Pereira, elite guerreira peninsular que nos anos posteriores à Batalha do Salado geriam uma das maiores e mais poderosas ordens religioso-militares do Ocidente (COSTA, 2013, pp. 228-229). Vale ressaltar

\footnotetext{
${ }^{65} \mathrm{O}$ frei André do Amaral também chegou a ser eleito Prior do Crato, embaixador do Grão Mestre da Ordem do Hospital, membro do Conselho Régio de D. Manuel e comendador de Ansemil, Alcafache, Vera Cruz de Marmelar e Vila Cova à Coelheira. Além disso, ainda participou do Grande Cerco de Rodes em 1522, lutando pela defesa da ilha, naquele momento atacada pelos Turcos.
} 
que Conde D. Pedro provavelmente tinha interesses em promover tal história, tendo em vista que havia se casado, em um segundo casamento, com a filha dos senhores de Portel, ambos interessados em prestigiar as aristocracias de Portel e Marmelar.

De acordo com Fátima Regina Fernandes (2011, p. 83) ${ }^{66}$ :

No relato do Livro de Linhagens todos os guerreiros são inflamados do mesmo espírito cruzadístico, próprio dos monges-guerreiros e se convertem em instrumentos providencialistas de um destino de defesa da fé nos territórios cristãos da Península Ibérica. Contaminados pela ideologia hospitalária, os fidalgos portugueses compreenderiam neste episódio de grande aflição o seu destino e missão dentro da Cristandade, serem como guerreiros leões ou cordeiros obedientes prontos ao sacrifício em conformidade com os desígnios divinos. Uma narrativa sem dúvida sacralizadora dos modelos nobiliárquicos portugueses a partir do ideário das Ordens Militares, transformando os portugueses em povo escolhido por Deus para uma função indispensável, a defesa de sua fé; um duradouro destino providencialista se anunciava ao reino português e apresentava-se como nos diz Saraiva, num estilo "elegante, erudito, alatinado, com tendência para o arredondamento oratório e para os arquétipos idealizados" (SARAIVA, 1971, p. 16) ${ }^{67}$.

A partir da divulgação do Livro de Linhagens, criou-se uma memória coletiva ${ }^{68}$, transmitida por séculos, que fez a articulação entre a Ordem do Hospital, os Pereira, a Coroa Portuguesa, a Batalha do Salado, a relíquia da Vera Cruz e o Movimento de Cruzada.

Ainda citando Fátima Regina Fernandes (2011, p. 82):

Assim, no relato do Livro do Conde D. Pedro, é o Prior quem profetiza ao rei português que ao colocar a bandeira da Santa Cruz do Marmelar como intercessora junto a Deus da fé dos portugueses alcançaria a vitória antes

\footnotetext{
${ }^{66}$ Fátima Regina Fernandes ainda traça um paralelo entre o perfil de atuação dos guerreiros cristãos no relato do Livro de Linhagens do Conde D. Pedro com o modelo dos cavaleiros de Ordens Militares tecido por Bernardo de Claraval no tratado De la excelencia de la nueva milicia dedicado aos cavaleiros da Ordem do Templo. Vide FERNANDES, 2011, pp. 75-91.

${ }^{67}$ Nota da própria autora, referindo-se à obra: "SARAIVA, O autor da narrativa da batalha do Salado e a refundição do Livro do Conde D. Pedro, p. 16, n 2 ".

${ }^{68}$ Quando nos referimos à "memória coletiva", nos aproximamos dos conceitos de memória elaborados por Paul Ricoeur em A Memória, a História, o Esquecimento (2007) e por Jacques Le Goff em História e Memória (2006). Segundo Ricoeur, procuramos compreender uma conciliação entre memória e história. Entendemos a memória como um processo cognitivo, como remomoração. A memória é a representação no presente de algo ausente, que no passado chegou a existir. A memória pretende ser fiel ao passado, mas para criarmos uma imagem representativa do passado precisamos de imaginação. A imaginação é voltada para a ficção, para o fantástico. Contudo, memória e imaginação, para Ricoeur, são indissociáveis, apesar de serem distinguíveis. A memória se alia à imaginação para auxiliar no conhecimento do passado. A aliança entre memória e imaginação serve para criar uma imagem mais fiel do que se passou, colaborando para se descobrir uma "versão mais verdadeira do passado". De acordo com Le Goff, "a memória coletiva é não somente uma conquista, é também um instrumento e um objeto de poder", pois permite também uma dominação da recordação e da tradição. "A memória onde cresce a história, que por sua vez a alimenta, procura salvar o passado para servir o presente e futuro".
} 
mesmo dos castelhanos. As falas são dirigidas por um monge hospitalário, mas os agentes da luta a serem animados são genericamente identificados como fidalgos, sem menção aos representantes de outras ordens militares ali presentes, todos pertenceriam à hoste cristã, liderada e incentivada pelo Prior da Orde do Hospital. Em determinado momento da batalha, segundo a narrativa a Cruz não é mais vista e os portugueses tentam animar-se mutuamente com valores norteados pela ética cavalheiresca, animados pela similitude aos atos heroicos de seus antepassados, apostando na violência indiscriminada e na luta sangrenta. A salvação das mulheres e famílias dá um tom prioritariamente nobiliárquico à motivação, no entanto, quando a situação torna-se ainda mais crítica as exortações dos cavaleiros entre si assumem um tom cada vez mais de sacrifício pela fé diante da morte certa.

Analisando o contexto da Batalha do Salado, percebemos que há na Península Ibérica uma apropriação de ideais cruzadísticos, tendo em vista que a associação entre a Ordem do Hospital e a relíquia do Santo Lenho já existia desde o século XII, quando “o Papa Alexandre III insistiu junto do Grão Mestre Hospitalário que a primeira obrigação da Ordem era o cuidado dos pobres e que só deveria aceitar participar em campanhas militares, desde que a relíquia da Santa Cruz acompanhasse o exército cristão" (RILEY-SMITH, 2008, p. 255 apud COSTA, 2013, p. 227). Desde então a Santa Cruz é uma referência para as ações militares dos hospitalários. Além disso, convém mencionar que quando os cruzados conquistaram Jerusalém, em 1099, a relíquia da Cruz de Cristo apareceu e fora levada para a Igreja do Santo Sepulcro, além de confiada à Ordem do Templo, que a levava para batalhas (CORRAL, 2006, pp. 226-227 apud COSTA, 2013, p. 227). Fica claro, assim, que o Alentejo se tornara um espaço de reprodução de conceitos associados à Cristandade Oriental, à Jerusalém e à Cruzada.

Ressalta-se, então, o protagonismo de duas famílias, muito ligadas à Ordem do Hospital e à consolidação de suas presenças em torno de Marmelar e da Flor da Rosa: os de Góis-Farinha e os Pereira. Os primeiros, desde o século XIII ligados à Marmelar, tendo como principal nome o do Prior Afonso Peres Farinha. Os segundos, associados ao Santo Lenho em pleno século XIV, principalmente no contexto da Batalha do Salado (1340), tendo como principais nomes o Prior Álvaro Gonçalves Pereira (grande homem da Batalha do Salado, comendador de Flor da Rosa/Crato) e frei Gonçalo Pires Pereira (Grão-Comendador nos cinco Reinos de Espanhã).

Ao frei Afonso Peres Farinha, sepultado em Marmelar, atribuiu-se a busca da relíquia no Ultramar. Ao frei Álvaro Gonçalves Pereira, personalidade de destaque na Batalha do Salado e, posteriormente, sepultado no mosteiro da Flor da Rosa/Crato, atribuiu-se a busca e exibição do Santo Lenho na Batalha do Salado. 
Respondendo às primeiras perguntas feitas no início deste tópico: I) Por que houve essa transferência de sede? II) Quem foi ou quais foram os responsáveis pela transferência? III) Por qual ou quais motivos isso ocorreu? VI) Quais as consequências disso para a Ordem, para a Coroa, para a nobreza e para a população local?

Segundo Paula Pinto Costa (2013, p. 231 $)^{69}$ :

Paralelamente à definição do estatuto da comenda de Marmelar, quando os rendimentos económicos resultantes da exploração da terra se retraem, a partir de meados do século XIV, a comenda de Flor da Rosa, vê-se impulsionada por uma força régia-nobiliarquica que lhe garante uma posição singular na história do reino e da Ordem. No contexto na vitória do Salado, deu-se a mudança da sede da Ordem do Hospital de Leça do Balio para o núcleo Flor da Rosa/Crato. Em 1341, o prior Álvaro Gonçalves Pereira fundou uma capela no termo do Crato, que estaria na origem da casa conventual da Flor da Rosa. Com esta disposição reforça a presença da instituição nesse território, onde já existia um castelo que ele próprio ocupava e se transformou em sede do priorado. Álvaro Gonçalves Pereira ter-se-ia deslocado ao convento de Rodes com 25 cavalos, tendo sido recompensado com a atribuição da dignidade de prior do Crato, por iniciativa do Grão-Mestre. A construção da Flor da Rosa, cerca de setenta/oitenta anos mais tarde que Marmelar, representa um reforço da mensagem associada à Vera Cruz. Uma vez travada a batalha do Salado (1340) e atribuído o poder vitorioso e salvífico à relíquia depositada em Marmelar, acentuou-se uma lógica de continuidade entre estes dois espaços, integrando-os num universo comum. Admitimos, assim, que a Flor da Rosa tenha sido construída como uma forma de reação em relação a Marmelar, por vontade dos Pereira, funcionando como uma espécie de imagem refletida no poder emanado desse primeiro mosteiro de Marmelar, por via do Santo Lenho.

A transferência da sede da Ordem do Hospital em Portugal de Leça do Balio, cujo complexo monástico havia sido recém-reformado entre 1306 e 1336, para o Crato se deu primeiro porque a região da Flor da Rosa era região fronteiriça e requisitava maior presença de cavaleiros, segundo porque havia desde D. Sancho II imposição régia para povoamento e defesa do local (era a condição colocada na doação das terras aos hospitalários) e terceiro porque o Prior da Ordem do Hospital, D. Álvaro Gonçalves Pereira, também comendador de Flor da Rosa, havia mandado construir um mosteiro no Crato, edificado entre as décadas de 40 e 50 do século XIV. O mosteiro de Leça, primeira sede conventual dos hospitalários em Portugal, apesar de reconstruído, era estrategicamente limitado por estar situado muito ao

${ }^{69}$ Segundo a mesma autora, "apesar de haver várias lendas que procuram dar resposta à curiosidade sobre a origem do nome Flor da Rosa, uma delas diz que Rosa poderá derivar da palavra Rodes (em grego rodon significa rosa). Rodes é a ilha onde se encontrava o convento central desta instituição desde a segunda década do século XIV e já não era a primeira vez que se incorporava na toponímia Portuguesa hospitalária a inspiração oriental. Belver e Crato são bons exemplos: Belver em homenagem à fortaleza israelita com o mesmo nome e Crato em homenagem ao castelo sírio designado Crac dos Cavaleiros" (COSTA, 2013, p. 232). 
Norte. Já a região do Crato, esta já possuía um castelo ocupado pelos freires da Ordem desde 1232 e estava numa região em que se encontrava a nova centralidade dos interesses do reino.

Havia, no século XIV imensa instabilidade nas relações de Portugal com reinos ibéricos vizinhos, daí a convergência dos interesses tanto dos hospitalários quanto do rei de Portugal em aumentar o prestígio, a força militar e o povoamento na região do Crato. Foi o ano de 1356, o que por tradição se atribui à fundação do paço da Flor da Rosa (COSTA, 2010, p. 58). O mosteiro do Crato ganha ainda maior prestígio quando o Prior Álvaro Pereira, o protagonista da Batalha do Salado, é enterrado em seu interior, "com três outros cavaleiros que com ele foram buscar a Vera Cruz" (FONSECA, 2013, doc. 14) ${ }^{70}$.

Segundo Fátima Regima Fernandes (2011, p. 83 $)^{71}$ :

Assim, os guerreiros cristãos em sua maioria laicos no Salado, identificados
como portugueses ou fidalgos teriam demonstrado uma sintonia com valores
dos monges-guerreiros, era como se naquele palco de guerra-santa por
milagre prevalecessem princípios cristãos transformando-os todos em
clérigos guerreiros. Tal condição lógica que culminaria no milagre da vitória
dos portugueses frente aos grupos de muçulmanos que lhes cabiam
combater. Guerreiros sangrentos convertidos em mártires em vida que
aceitam seu destino e missão, que se entregam à morte pela fé e que com
este desprendimento grajeiam a vitória sobre seus inimigos. Em meio à
iminente derrota, às muitas chagas e aos braços cansados os portugueses
vislumbram novamente a Cruz do Marmelar que inflama sua coragem
destemida diante da morte como se fosse uma relíquia. Assim, ao
reencontrar a bandeira-relíquia, o Prior e os três cavaleiros que com ele
acharam a Santa Cruz do Marmelar caída e a reergueram recobrando as
forças das hostes cristãs seriam os intermediários da salvação da Cristandade
neste dia e mais tarde seriam sepultados todos juntos ao redor do sepulcro do
prior na Capela de Santa Maria de Flor da Rosa no Crato.

Quando se dá a transferência de sede de Leça do Balio para o Crato, a Ordem do Hospital passa a ter três locais principais de atuação no reino de Portugal: a comenda de Leça, a partir de então mais voltada para as obras assistenciais aos peregrinos (mas sempre preparada para guerra, o que se comprova pela forma bélica da arquitetura de sua igrejafortaleza); a comenda de Marmelar, cuja família nobre dominante era a dos Góis-Farinha; e a comenda da Flor da Rosa, cuja família de maior prestígio era a dos Pereira; essas duas útimas com a missão maior de proteger as fronteiras. Entretanto, não podemos nos esquecer de que

70 Essas citações FONSECA, 2013 que apareceram neste capítulo referem-se ao Volume 16 da Coleção Militarium Ordinum Analecta, sendo este volume intitulado A Comenda de Vera de Cruz de Marmelar: corpus documental (1258-1640), no qual são apresentadas fontes relativas à comenda hospitalária de Vera Cruz de Marmelar. São 89 documentos, desde meados do século XIII até 1640. A coordenação deste trabalho é de Luís Adão da Fonseca, tendo como coautores Paula Pinto Costa, Joana Lencart e ele próprio.

71 Apesar de esta autora utilizar a expressão monge-guerreiro, sabe-se que os membros de ordens religiosomilitares eram freires, e não monges. 
ambas as comendas eram exploradas economicamente e que tinham também como objetivo o envio de recursos materiais e humanos ao Convento Central da Ordem do Hospital na Ilha de Rodes.

Sobre os habitantes dessas duas últimas comendas mencionadas, Marmelar e Flor da Rosa, há aumento populacional nestes espaços à medida em que os freires se instalam e que privilégios régios e pontifícios atraem trabalhadores para a região, a fim de trabalho com gado e lavoura em troca de proteção militar e isenções diversas, como as já citadas anteriormente neste tópico. No caso de Marmelar, ainda havia a feira, incentivada pelos monarcas e cujos frutos econômicos eram bastante significativos.

Com esta transferência de sede, a família Pereira consolida sua influência na região da Flor da Rosa. A Ordem do Hospital continua reafirmando sua identidade militar, tanto é que que passa a se sediar junto do Castelo do Crato e nas proximidades do Castelo de Belver, poderosos símbolos da grandeza militar de Portugal, mas também deixa clara sua intenção de manter as obras de ajuda aos pobres e necessitados, tanto é que também funda uma capela em honra de Santa Maria em Flor da Rosa. Os Pereira continuam no comando da Ordem do Hospital em Portugal, mesmo após a morte de Álvaro Gonçalves Pereira, que fora sucedido no Priorado por seu filho, D. Pedro Álvares Pereira ${ }^{72}$ e depois por seu primo em segundo grau D. Álvaro Gonçalves Camelo. Falaremos mais sobre a sequência dos priores após Álvaro Gonçalves Pereira, no próximo tópico desta tese.

Paula Pinto Costa se pergunta por que construir a Flor da Rosa em meados do século XIV, sendo que do ponto de vista financeiro esta opção era aparentemente irracional. Para responder à esta questão esta historiadora inicia o seguinte raciocício (2013, p. 233):

A imagem de marca da Flor da Rosa é a mesma que já fora usada em Leça-
uma igreja-fortaleza - que ostenta um programa construtivo conotado com
símbolos de prestígio senhorial de uma linhagem e com os objetivos
programáticos de uma ordem que se quer continuar a legitimar, também,
pela vertente militar, para além da clássica religioso-assistencial. O momento
em que foi feita a associação dos Pereira ao relato da batalha do Salado
coincidiu com a mudança de sede da Ordem para o núcleo Crato/Flor da
Rosa, num horizonte conceptual de Cruzada, que suporta como que uma
refundação da própria Ordem e apela a um cenário mais amplo. Estávamos
em meados do século XIV, altura em que se avolumaram as dificuldades no
Mediterrâneo Oriental, em que os Templários tinham sido extintos, em que

${ }^{72}$ Não é nosso objetivo neste trabalho traçar a árvore genealógica dos Pereira e nem analisar o papel militar e político dos descendentes de Álvaro Gonçalves Pereira. Contudo, vale mencionar que tal Prior era filho legitimado e clérigo do Arcebispo de Braga Gonçalo Gonçalves Pereira (este também Bispo de Évora e Lisboa). Além disso, é importante mencionar que Álvaro Gonçalves Pereira era pai do Condestável D. Nuno Álvares Pereira. Acerca deste assunto, consultar: MATTOSO, José. Portugal Medieval; e MATTOSO, José. A Nobreza Medieval Portuguesa. 
os Hospitalários fortificavam a ilha de Rodes e assumiam a defesa da Cristandade frente ao Turco. Por sua vez, em terras peninsulares, o grande herói do Salado foi o Prior Hospitalário Álvaro Gonçalves Pereira, que sintetiza a importância do Alentejo nessa altura, enquanto terra de recente incorporação cristã. Tudo aponta para uma encenação de poder orientada pela incorporação de referências provenientes da Cristandade Latina e pela sua recriação a Ocidente; se a Oriente a Cristandade se torna cada vez mais vulnerável, em Portugal, a Ordem do Hospital assume a estratégia de reproduzir um novo foco da Cristandade no Alentejo. Neste cenário reforçase a inteligibilidade da criação da Ordem de Cristo, em 1319, e a sua instalação em Castro Marim, com o propósito de concretização da Cruzada em espaços extra Portuguses.

E conclui assim (COSTA, 2013, p. 233):

À luz deste raciocínio, de comendas situadas em pleno Alentejo, Vera Cruz de Marmelar e Flor da Rosa, foram transformadas em espaços de projeção do Oriente Latino e em pólos com elevada carga simbólica, mobilizadores para além da região em que se situam. No eixo Marmelar/Flor da Rosa, a Ordem do Hospital recria uma segunda Jerusalém (em Marmelar por via do Santo Lenho) e uma segunda Rodes (em Flor da Rosa por via da manifestação da dimensão militar).

Imagem 4 - Túmulo de D. Álvaro Gonçalves Pereira, em Flor da Rosa

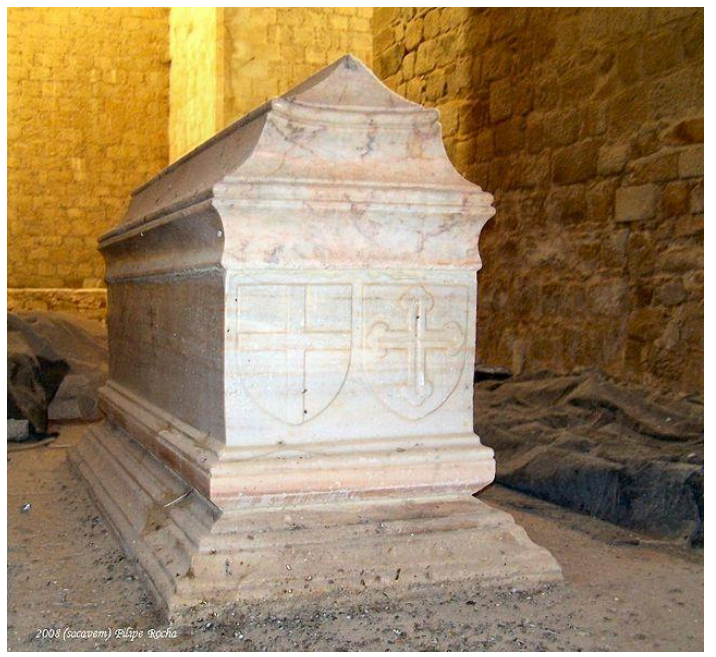

Fonte: SACAVEM1. Túmulo de D. Álvaro Gonçalves Pereira, em Flor da Rosa. Disponível em: https://commons.wikimedia.org/wiki/File:T\%C3\%BAmulo_de_D._\%C3\%81lvaro_Gon\%C3\%A7alves_Pereira. JPG. Consultado em: 20 de março de 2015.

Por fim, fica bastante claro que há uma forte carga simbólica de elementos do Movimento de Cruzada inserida no contexto da Ordem do Hospital em Portugal, tanto é que há essa "recriação" da Terra Santa no Alentejo, a utilização do nome Belver para o imponente castelo militar dos hospitalários em Portugal e a associação da igreja da Flor da Rosa, também uma igreja-fortaleza, à toponímia de Rodes e ligada à memória da Batalha do Salado. E ainda 
vale mencionar o perfil devocional criado na Comenda de Vera Cruz de Marmelar, por causa da relíquia do Santo Lenho.

Acerca dessa discussão sobre elementos ideológicos inseridos em Portugal após a Batalha do Salado, Fátima Regina Fernandes (2011, p. 86) afirma que o reino e a nobreza, "fortemente interdependentes constroem suas bases de afirmação e legitimação nos mesmos suportes e instrumentos ideológicos, a estabilidade do extrato nobiliárquico, nutriz da instituição monárquica resulta num rei fortalecido e num reino estável”. Ou seja, o aumento de prestígio e de poder das famílias nobres ligadas aos hospitalários em Portugal, não somente favorecia aos interesses da Ordem do Hospital como um todo, como também da própria monarquia, que se via fortalecida à medida em que a memória social da Batalha do Salado, com seus heróis e providências divinas, se tornava mais real.

\subsection{A FAMÍLIA ATAIIDE: OS PRIORES JOÃO DE ATAÍDE E VASCO DE ATAÍDE}

Após a análise sobre a transferência da sede da Ordem do Hospital em Portugal de Leça do Balio para o núcleo Flor da Rosa/Crato, consideramos importante mencionarmos os nomes dos priores que sucederam a D. Álvaro Gonçalves Pereira até chegarmos à figura central de nossa pesquisa, o Prior D. Vasco de Ataíde.

De acordo com informações obtidas na tese de doutoramento de Paula Pinto Costa, apresentada à Universidade do Porto e publicada nos Volumes 3 e 4 da Revista Militarium Ordinum Analecta, no ano 2000 (pp. 249-250), depois da morte do Prior D. Álvaro Gonçalves Pereira, há vários documentos que mencionam passagens de outros freires na dignidade prioral até chegarmos no primeiro documento que menciona o Prior D. Vasco de Ataíde. Abaixo, listamos, por mera informação, os priores do Crato de 1380 a 1508:

*Pedro Álvares Pereira (1380 - 1425);

*Lourenço Esteves de Góis (1362 - 1401);

*Álvaro Gonçalves Camelo (1383 - 1417);

*Nuno Gonçalves de Góis (1419 - 1440);

*Afonso Pires Sardinha (1440 - ?);

*Henrique de Castro (1442 - 1448);

*João de Ataíde (1448 - 1453);

*Vasco de Ataíde (1453 - 1487); 
*Álvaro Pires de Avelar (1478 lugar tenente - ?);

*Diogo Fernandes de Almeida (1480 eleito - 1508).

Vale ressaltar que alguns priores foram eleitos e não tomaram posse e que outros priores ocuparam o cargo como "lugar-tenente" na ausência temporária de outro prior. Alguns chegaram, inclusive, a ser eleitos e a ocuparem o cargo mais de uma vez (COSTA, 2000, p. 249).

No caso do Prior D. Vasco de Ataíde, objeto central de nossa análise, o primeiro documento encontrado que demonstra a sua titularidade como Prior do Crato é de 09 de janeiro de $1453^{73}$ e o último registro sobre sua atuação à frente do ramo português da Ordem do Hospital é de 14 de março de $1487^{74}$.

D. Vasco de Ataíde era filho de D. Álvaro Gonçalves de Ataíde, conde de Atouguia e antigo aio de D. Afonso V e governador da casa do infante D. Pedro, e de D. Guiomar de Castro. Era também irmão de D. João de Ataíde, prior do Crato a quem sucedeu em 1453. A proximidade da família Ataíde à Coroa era tão intensa que D. Vasco de Ataíde chegou a ser padrinho de D. João II e conselheiro régio, além de Prior da Ordem do Hospital em Portugal (BELLO, 1931 apud COSTA, 2000, p. 273).

Contudo, antes de entrarmos em maiores detalhes acerca de Vasco de Ataíde, precisamos explicar por que a família Ataíde tinha tanto prestígio no século XV. Para entendermos a proximidade desta família com a corte de D. Afonso V, remontamos ao bisavô deste Prior, chamado Gonçalo Viegas.

Segundo a obra Brasões da Sala de Sintra, de Anselo Braamcamp Freire (1921-1930, Vol. 1, pp. 74-84), Gonçalo Viegas possuía em 1290, entre outros bens, a quinta do Pinheiro na freguesia de S. Pedro de Ataíde, julgado de Santa Cruz de Ribatâmega, atual Concelho de Amarante. Supostamente, esta quinta já pertencia aos seus antepassados, o que, se for verdade, demonstra que talvez a família já tivesse certo prestígio há bastante tempo, vindo nesta época a inserir o nome Ataíde à linhagem.

O avô de D. Vasco de Ataíde, Martim Gonçalves de Ataíde (filho de Gonçalo Viegas), segundo Anselmo Braamcamp, "era fidalgo de boa casa e de ilustre ascendência. Sobre a origem de sua família há opiniões encontradas e nenhuma, a dizer a verdade, fundada em base segura" (1291-1930, Vol. 1, p. 80). Entretanto, a mesma obra afirma que Martim Gonçalves de Ataíde causou-se com Mercia Vasques Coutinho (que depois de viúva foi aia dos infantes filhos de D. João I) e com ela teve os seguintes filhos: I) Álvaro Gonçalves de Ataíde; II)

\footnotetext{
${ }^{73}$ A.N.T.T., Leitura Nova, Guadiana, 1. 3, fl. 160.

${ }^{74}$ A.N.T.T., Gavetas, XI, m. 7, no 10 e Leitura Nova, Direitos Reais, 1. 1, fls. 85v-88v.
} 
Vasco Fernandes de Ataíde; III) D. Isabel de Ataíde; IV) D. Helena de Ataíde; V) D. Felipa de Ataíde; VI) Caterina de Ataíde.

Álvaro Gonçalves de Ataíde foi o pai de D. João de Ataíde e de D. Vasco de Ataíde, ambos os filhos, respectivamente, priores do Crato no século XV. Álvaro Gonçalves de Ataíde foi Conde de Atouguia "por carta de Dezembro de 1448, e morreu antes de 14 de Fevereiro de 1462, data da carta do título de conde da Atouguia a seu filho D. Martinho de Ataíde" (FREIRE, 1291-1930, Vol. 1, p. 82).

Segundo Anselo Braamcamp Freire (1291-1930, Vol. 1, p. 84):

Foi D. Álvaro Gonçalves de Ataíde progenitor dos demais Condes da Atouguia, que no fim do século XVI já tinham a varonia de Câmara, e dos quais o último morreu no cadafalso de Beiêm, a 13 de Janeiro de 1759. Foi igualmente progenitor dos Condes da Castanheira (1 de Maio de 1532), dos quais saiu o ramo dos Condes de Castro Daire (20 de Junho de 1625) e nestes veio posteriormente a fundir-se o ramo originário. A sua varonia extinguiu-se próximo dos fins do século XVII, passando os bens vinculados para a casa dos Marqueses de Cascais. Do $1^{\circ}$ Conde da Atouguia procederam mais ramos de Ataides relativamente obscuros, e nos quais creio estar, há muito, perdida a varonia.

Outra personalidade importante fora Vasco Fernandes de Ataíde, irmão de Álvaro Gonçalves de Ataíde e tio de D. Vasco de Ataíde (o Prior). Vasco Fernandes de Ataíde era fidalgo da casa real "com quinhentas e quatro libras de moradia por mês, foi vedor da casa do infante D. Henrique e a seu lado morreu na tomada de Ceuta, em 1415, sem deixar geração". Ou seja, Vasco Fernandes de Ataíde era possivelmente bastante admirado em seu seio famíliar, tido como o único cavaleiro português morto naquela batalha, "derrubado por uma grande pedra lançada das muralhas. Ao facto alude uma inscrição num penhasco sob uma torre, parecendo ser aquele letreiro o único vestígio subsistente da permanência dos Portugueses em Ceuta" (FREIRE, 1291-1930, Vol. 1, p. 84). Segundo este autor, a inscrição é constituída pelo seguinte epigrama: Vascus Ataydes primus dum hanc occiípat arcem; Saxum hoc ã̃ limen vitaque, morsque fuit. "Como quem dissesse que esta pedra fora para Vasco de Ataíde, o primeiro a entrar nesta fortaleza, ao mesmo tempo a sua vida e a sua morte".

Sobre os demais tios de D. Vasco de Ataíde, Freire diz o seguinte (1291-1930, Vol. 1, p. 84)

D. Isabel de Ataíde foi primeira mulher, com geração, de D. Fernando de Castro, senhor do paúl do Boquilobo. 
D. Helena de Ataíde casou com Pedro Vaz da Cunha, 2. ${ }^{\circ}$ senhor de Angeja e Pinheiro, de quem teve geração.

D. Felipa de Ataíde, dama da rainha D. Felipa de Lancastre com mil e duzentas libras de moradia, foi a primeira mulher de Gonçalo Anes Chichorro, $3 .^{\circ}$ senhor de Mortágua.

Caterina de Ataíde, dama da mesma Rainha, teve igual moradia na sua casa.

Analisando a família Ataíde, percebe-se que antes de D. Vasco de Ataíde, há décadas seus antepassados já eram senhores feudais, com significativos títulos de nobreza e com íntima ligação à Coroa Portuguesa. Além disso, seu tio Vasco Fernandes de Ataíde havia sido cavaleiro próximo do infante D. Henrique, sendo lembrado como herói por morrer na Batalha de Ceuta, em 1415. Suas tias, Filipa e Caterina de Ataíde, foram damas da Rainha D. Felipa de Lancastre.

Segundo Rita Costa Gomes (1995, pp. 92-93):

No exemplo dos Ataídes, vemos a sua influência crescer à sombra dos Teles no período fernandino, de modo tal que vêm a integrar o grupo dos "Grandes" na corte joanina e, ocupando uma multiplicidade de posições junto dos infantes, acabam por constituir um importante elemento da nobreza cortesã de Quatrocentos Assim, os irmãos Nuno e Martim Gonçalves de Ataíde I acompanham D. Afono IV, enquanto Gil Martins de Ataíde faz parte do séquito de D. Pedro ainda infante. Na corte fernandina Martim Gonçalves de Ataíde II e Gonçalo Viegas de Ataíde são protegidos por Leonor Teles. Os descendentes de ambos acompanham D. João I e seus filhos: Álvaro Gonçalves de Ataíde e seu irmão Vasco Fernandes, Pero Nunes e Nuno Gonçalves de Ataídes. Nos séquitos de D. Duarte e D. Afonso V integra-se a descendência de Nuno Gonçalves de Ataíde, como Pero de Ataíde II. Mas também a de Álvaro Gonçalves: Martinho de Ataíde e os priores do Hospital João e Vasco de Ataíde, e ainda Álvaro de Ataíde II. Entre os mais jovens desta família, em meados do século $X V$, estão na corte Filipe de Ataíde e Pedro de Ataíde III.

A família dos Ataíde se caracterizou pela sua participação duradoura na sociedade de corte portuguesa dos finais da Idade Média. Alguns, como mencionamos anteriormente, ocuparam cargos de condes, conselheiros régios, damas de rainhas e líderes de Ordens Militares. Em uma época em que os reis precisavam tanto dos nobres quanto os nobres precisavam do monarca, esse tipo de aliança régia favorecia o alcance dos objetivos da Coroa, assim como perpetuava determinadas linhagens no estrato superior da nobreza.

Vale ressaltar que o próprio irmão de D. Vasco de Ataíde, D. João de Ataíde, também fora prior do Crato, antes dele, de 14 de outubro de 1448 até perto de 14 de março de 1453 
$\left(\right.$ COSTA, 2000, p. 250) ${ }^{75}$. D. Vasco assume o Priorado logo após a morte de D. João de Ataíde, em $1453^{76}$.

João de Ataíde era freire membro da Ordem de Cristo, tendo recebido o Priorado do Crato por decisão papal (Bula Apostolicae Sedis, de Nicolau V, em 14 de outubro de 1448), que também exigia (em troca) que ele e seus sucessores pagassem pensão vitalícia de 100 mil reais brancos a D. Henrique de Castro, conforme pedido do rei e do infante D. Pedro ${ }^{77}$.

D. João de Ataíde fora um prior dedicado nas suas funções administrativas dentro do Priorado e também bastante focado na luta contra o Islã. Em 1444, liderou um significativo grupo de guerreiros na ocasião do cerco que o Sultão do Egito fez à ilha de Rodes, onde estava sediado o Convento Central da Ordem do Hospital (BELLO, 1931, p. 64), ganhando imenso prestígio por isso, tendo em vista a vitória dos hospitalários. Quatro anos depois, fora enviado por D. Afonso V à Roma, a fim de jurar obediência ao novo Papa Nicolau V, ficando notória sua afinidade com o rei de Portugal.

Segundo Paula Pinto Costa (2000, p. 262):

Em 5 de março de 1450, D. Afonso V levantou o degredo de Ceuta ao provedor, Vasco Gil, e escudeiros de Fr. João de Ataíde, Prior da Ordem do Hospital, na sequência de um diferindo a propósito da posse da comenda de Leça. Com efeito, Fr. João de Ataíde, dizia que estava em posse desta câmara há cinco ou seis meses, em função de um alvará régio, contestando assim, as pretensões de João Coelho, em relação à mesma casa. As dissensões entre João de Ataíde e João Coelho não terminaram, pois no ano de 1452 seria proferida uma sentença, pela qual era atribuído ao segundo, na qualidade de responsável pela comenda de Leça, o direito de padroado sobre a igreja de S. Vicente de Tougues.

Apesar desses contratempos, podemos afirmar que a relação entre D. Afonso V e D. João de Ataíde era de proximidade, tanto é que em 5 de abril de 1452, o monarca confirmou ao Prior diversos privilégios que haviam sido concedidos à Ordem do Hospital por D. João I e por D. Duarte ${ }^{78}$.

Ainda sobre D. João de Ataíde, Paula Pinto Costa diz o seguinte (2000, pp. 262-263):

A influência que este homem tinha junto do rei é notável e, em virtude de um pedido seu, a 7 de Abril do ano 1451, o rei privilegiou Martinho Davy, físico, morador em Tomar, para que pudesse andar de besta muar de sela e

\footnotetext{
${ }^{75}$ Essa autora faz referência à documentação que diz respeito à essa informação: Monumenta Henricina, vol. IX, doc. 201, pp. 321-326 e doc. 202, pp. 326-331 e A.N.T.T., Chancelaria Afonso V, 1. 3, fl. $27 \mathrm{v}$.

76 A.N.T.T., Leitura Nova, Guadiana, Liv. 3, fl. 160.

${ }^{77}$ Monumenta Henricina, Vol. IX, doc. 201 e 202.

${ }^{78}$ A.N.T.T.; Chancelaria de D. Afonso V, 1. 12, fl. 42v.
} 
freio, por todo o reino ${ }^{79}$. Igualmente por intermédio de João de Ataíde, em 17 de Abril de 1452, o monarca nomeou Afonso Eanes para o cargo de tabelião do cível e crime na vila da Sertã e seu termo, em substituição de Estevão Martins, que morrera ${ }^{80}$. Em 14 de Março de 1453, D. Afonso V quitou ao Prior, João de Ataíde, que então morrera, o preito e menagem dos seus castelos ${ }^{81}$, uma vez que D. João fora alcaide das fortalezas da Amieira, do Crato e da Flor da Rosa, antes e depois da batalha de Alfarrobeira.

Quando D. Afonso V atingiu a maioridade começou a preparação para suas jornadas no Norte da África. Encontrou nos hospitalários aliados preciosos. A participação da Ordem do Hospital nessas empreitadas foi impressionante a tal ponto que o monarca mandou passar uma Carta de Confirmação de todos os privilégios, mercês e isenções que lhes tinham concedido os monarcas antecessores ${ }^{82}$. Além disso, outorgava-lhes também as demais prerrogativas de que a Ordem de Cristo usufruía, caso o Hospital ainda não estivesse gozando das mesmas.

Sobre a relação entre D. Vasco de Ataíde e D. Afonso V, falaremos mais no próximo capítulo.

É preciso explicar que o acesso às ordens militares aumentava ainda mais o prestígio de uma família, tendo em vista que essas instituições serviam muitas vezes como exércitos a serviço do monarca, e que seus freires muitas vezes recebiam comendas importantes e alcançavam altos cargos dentro da instituição, o que permitia quase sempre uma melhoria no status social e também poder jurisdicional. Além disso, na maioria dos casos, os comendadores, priores e mestres se aproximavam mais do círculo de poder real, obtendo cargos de conselheiro, por exemplo.

Para ter acesso à Ordem do Hospital, por exemplo, era necessário apresentar uma comprovação de que o candidato vinha de família nobre, o que de fato era um fator relevante a ser considerado. No entanto, é provável que esta comprovação deveria ser feita, sobretudo, pelos que queriam ingressar como cavaleiros. Talvez, os que ingressavam como serventes e até os donatos seriam aceitos mediantes diferentes critérios (COSTA, 2000, p. 242).

Diversas famílias nobres conseguiram maior ascensão social ao ingressarem seus membros na Ordem de São João, a citar os Pimentel, ligados aos Pereira, os Andrade, os de Góis, os Camelo, e os de Avelar, todos fizeram carreira neste meio. Ao mesmo tempo, isso demonstra a proximidade dos cavaleiros dessas ordens à Coroa. No geral, o acesso às ordens

\footnotetext{
${ }^{79}$ A.N.T.T., Chancelaria de D. Afonso V, 1. 12, fl.123v.

${ }^{80}$ A.N.T.T., Chancelaria de D. Afonso V, 1. 12, fl. 36.

${ }^{81}$ A.N.T.T., Chancelaria de D. Afonso V, 1. 3. fl. 27v.

${ }^{82}$ A.N.T.T.; Chancelaria de D. Afonso V, 1. 12, fl. 42v.
} 
militares só era permitido a quem pertencia ao estrato superior da aristocracia, o que justifica a existência de vários membros da mesma família nessas instituições.

Segundo Paula Pinto Costa (2000, pp. 243-244):

Os laços familiares entre alguns Hospitalários constituíram outra faceta curiosa verificada no seio deste universo humano. No entanto, noutras situações não foi o vínculo sanguíneo o elo de ligação a outros elementos, mas sim o vínculo social. Estamos a pensar em Álvaro Gonçalves Camelo, criado de Álvaro Gonçalves Pereira, a quem sucedeu no desempenho da titulatura do Priorado do Crato. Recordem-se, então, os casos em que as ligações familiares foram relevantes. Esta familiaridade entre os freires pode ser encontrada em famílias como os Pimentéis, a que já nos referimos, os Góis, os Ataíde e os Avelar. No primeiro caso, os priores Lourenço Esteves de Góis e Nuno Gonçalves de Góis eram irmãos entre si e Nuno foi pai de dois comendadores sanjoanistas, a saber, Fernando de Góis e Pedro de Góis. No segundo caso, os Ataíde, os priores João de Ataíde e Vasco de Ataíde eram filhos de Álvaro Gonçalves de Ataíde, primeiro conde de Atouguia, e de D. Guiomar de Castro. Outra senhora desta família, D. Isabel de Ataíde, casada com D. Fernando de Castro foi mãe de um outro Prior do Crato, D. Henrique de Castro. Para além destes exemplos, encontrámos um outro na família dos Avelar. Assim, pelo menos dois dos seus elementos foram cavaleiros Hospitalários, isto é, Diogo Afonso de Avelar e Álvaro Pires de Avelar. Só para terminar o elenco destes casos, recorde-se que o infante D. Luís era pai de D. António, e por ele foi coadjuvado e sucedido na dignidade de Prior do Crato.

Diante deste panorama, percebe-se que não era por falta de patrimônio e herança que as pessoas ingressavam nas ordens militares, mas sim por prestígio e para se inserirem em determinadas redes de poder.

Também escreveremos mais sobre a clientela de D. Vasco de Ataíde no capítulo seguinte deste trabalho, para compreendermos como se expandia as redes de poder mencionadas acima, no caso deste prior.

Vale ressaltar que durante os vários anos de pesquisa e escrita desta tese de doutoramento, procuramos a informação sobre o ano da morte de D. Vasco de Ataíde, dado que somente conseguimos obter recentemente. Esse prior faleceu, provavelmente, no ano de 1492, como atesta José de Anastasio de Figueiredo (1800, p. 90). Desta forma, elimina-se (pelo menos por enquanto) a confusão que havia entre esse Prior do Crato e o Vasco de Ataíde navegador, aquele que acompanhava Pedro Álvares Cabral na expedição ao Brasil em 1500 e que supostamente falecera num naufrágio na noite de 23 de março daquele ano, após a frota ter passado por Cabo Verde ${ }^{83}$. Segundo João Paulo Oliveira e Costa (2000), é provável

\footnotetext{
${ }^{83}$ Informação retirada da Carta de Pero Vaz de Caminha (NEVES, 1991). Entretanto, sabe-se pouco sobre tal navegador.
} 
que o navegador tenha sido um filho de D. Pedro de Ataíde, Abade de Penalva, que era filho bastardo de D. Álvaro Gonçalves de Ataíde, ou seja, sobrinho do Prior D. Vasco de Ataíde.

Após sua morte, Vasco de Ataíde fora sucedido no Priorado do Crato por D. Diogo Fernandes de Almeida, filho do primeiro conde de Abrantes, D. Lopo de Almeida, e de D. Brites da Silva. Diogo Fernandes de Almeida era irmão dos bispos D. Fernando de Almeida e D. Jorge, e irmão de D. Francisco de Almeida, segundo conde de Abrantes e futuro vice-rei da Índia, conforme consta na Crónica de D. João II e Miscelânia, de Garcia de Resende (1973, p 360). "D. Diogo Fernandes de Almeida chegou a ser membro do concelho régio, monteiro mor do rei e recebeu D. Jorge, filho bastardo de D. João II, para que o criasse e educasse $\left(\right.$ COSTA, 2000, p. 256) ${ }^{84 \%}$. D. Diogo participou nas guerras do Norte da África e era conselheiro régio para assuntos expansionistas ${ }^{85}$ e chegou a ser considerado rico-homem do conselho régio $^{86}$. Foi também aio e governador na casa de D. Jorge, em 12 de abril de 1492.

De acordo com Paula Pinto Costa (2000, p. 295):

\begin{abstract}
No ano de 1480, Maomé II cercou a ilha de Rodes, motivando o futuro Prior do Crato a partir em defesa de terras cristãs, ao que parece, já detentor do hábito da Religião. Numa carta que escreveu ao Papa Inocêncio VIII, entre outras coisas relativas à sua atividade, Diogo Fernandes de Almeida fez saber que entrara para a Ordem, durante o pontificado de Sisto IV, por isso, entre os anos de 1471 e 1484. Em 1492, assumiu o cargo de Prior do Crato, para o qual fôra eleito em 1480.
\end{abstract}

A documentação por nós analisada não é suficientemente esclarecedora acerca do início da titulatura de Diogo Fernandes de Almeida como Prior do Crato. Sabe-se que ele fora eleito ao cargo de Prior em $1480^{87}$, pois há documentação que registra isso, mas seu efetivo exercício no cargo só é constatado documentalmente a partir de 1492. Por isso, o recorte temporal desta tese de doutoramento vai até 1491, ano em que o nome de D. Vasco de Ataíde ainda aparece como representante da Ordem do Hospital, em um contrato de emprazamento de três vidas, a respeito de bens localizados na comenda de Távora ${ }^{88}$.

\footnotetext{
${ }^{84}$ Informação disponível: na Chronica de El Rei D. João II, de Rui de Pina (1950, caps. 80-83, na Crónica de D. João II e Miscelânea, de Garcia de Resende (1973, caps. 137, 144 e 216), nos Brasões da Sala de Sintra, de Anselmo Braamcamp Freire (1996, vol. II, pp. 361-362) e na obra de Paula Pinto Costa (2000, p. 256).

${ }^{85}$ Chronica de El Rei D. João II, de Rui de Pina (1950, cap. 27), Crónica de D. João II e Miscelânea, de Garcia de Resende (1973, caps. 67 e 81). Diogo de Almeida fora consultado por D. João II sobre o cerco à ilha Graciosa.

${ }^{86}$ A.N.T.T., Leitura Nova, Estremadura, 1. 5, fls. 294v-295.

${ }^{87}$ Brasões da Sala de Sintra, de Anselmo Braamcamp Freire (1996, vol. II, p. 361).

${ }^{88}$ A.D.B, Comendas, Távora (Santa Maria de), nº 50, doc. 15.
} 


\section{O PRIORADO DO CRATO E O REINO DE PORTUGAL}

\subsection{VASCO DE ATAIIDE E OS MONARCAS DE SUA ÉPOCA}

Uma das conclusões a que chegamos ao final de nossa dissertação de Mestrado, cursado entre 2008 e 2010, foi que a trajetória da Ordem do Hospital na Pensínsula Ibérica, nos séculos XII a XV, pode ser explicada pela estreita vinculação da milícia com as diferentes monarquias. Nos séculos XII e XIII os reis incentivaram e apoiaram a implantação e o desenvolvimento da Ordem pela via de concessão de privilégios e doações. É neste período que se formaram as mais importantes comendas hospitalárias ibéricas. Desta forma, a Ordem do Hospital de São João atuou como um instrumento do poder monárquico nas terras e junto às pessoas de cada um desses reinos. Além disso, os freires do Hospital participaram militarmente do processo de expansão territorial da Cristandade sobre terras islâmicas na Península Ibérica. Quem intermediava essa relação entre Coroa e Ordem dos Hospitalários era justamente o prior.

Vários desses priores, por terem se aproximado muito da realeza durante sua gestão ou mesmo por já serem de famílias ligadas à Corte, como por exemplo, Vasco de Ataíde e João de Meneses, receberam diversas doações e privilégios do monarca, o que demonstra que, de certa forma, os serviços prestados à realeza serviam como estratégia de ascensão social e/ou reprodução das hierarquias. E, obviamente, a aproximação dos priores ao monarca acontecia, também, como forma de se alcançar, às vezes mais facilmente, os objetivos do Priorado.

De acordo com Paula Pinto Costa (1997, p. 313):

Os monarcas vão respondendo a pedidos concretos da Ordem, sendo o Prior, como representante da mesma ao nível do priorado, o directo beneficiário das mercês régias. Nuns casos a benesse tem um caráter generalizado, noutros, porém, incide num domínio específico do senhorio da Ordem.

À medida que diminuíam as conquistas peninsulares sobre os muçulmanos, as doações à Ordem também diminuíam, fazendo entrar em crise o modelo de relações criado nos dois primeiros séculos de nossa análise. Aconteceu um processo de "senhorialização" 89 que fez

${ }^{89} \mathrm{O}$ processo de senhorialização ao qual fazemos menção foi a consolidação das prerrogativas dos senhores durante o reinado de $\mathrm{D}$. Afonso $\mathrm{V}$ e a adaptação da monarquia a um novo contexto em que poderosos nobres haviam surgido. Verificou-se que nos tempos de D. João I muitas concessões foram feitas àqueles que o 
com que os freires começassem a se identificar com os interesses da aristocracia, às vezes em detrimento de sua identificação com a monarquia. Por isso é que "las relaciones de los freires sanjuanistas con las diferentes monarquías sufrieron un reajuste a partir de comienzos del siglo XIV' (BARQUERO GOÑI, 2003, p. 90).

Segundo Carlos Barquero Goñi (2003, pp. 90-91):

Sin duda, las relaciones del Hospital con la realeza fueron las más decisivas para la presencia de la Orden en la Península Ibérica durante los siglos XIV y XV. Hasta el momento presente, el tema sólo se ha analizado con certo deternimiento en el caso de la Corona de Aragón, Portugal y, más someramente, en el de Navarra para dicho período de estudio. El panorama global que nos presenteam estos trabajos es el de una Orden muy ligada a la monarquía y estrechamente controlada por ella. En nuestra opinión, creemos que el citado modelo de relaciones entre realeza y hospitalarios puede ser extendido al resto de las monarquías peninsulares durante las dos últimas centurias de la Edad Media.

Foi bastante comum nos séculos XIV e XV, os reis ibéricos ratificarem à Ordem do Hospital, de forma sistemática, os privilégios e doações outorgados pelos seus antecessores, mas raramente essas graças e meercês eram ampliadas neste período. Em Portugal, os reis também confirmaram, por várias vezes, os antigos privilégios do Hospital. Em troca, os hospitalários prestaram constantes serviços ao seu monarca, destacando-se os serviços de natureza militar. Os freires da Ordem também prestavam outros serviços para as Coroas, como por exemplo, as mediações diplomáticas, servindo como porta-vozes e até pacificadores da relação dos monarcas com o Papado, relação esta que em vários momentos era bastante conflituosa.

Era comum em Portugal, na décima quarta e décima quinta centúrias, priores e comendadores sanjuanistas ocuparem elevados cargos na administração régia, consolidando cada vez mais o poder monárquico no reino. Essa conjuntura propiciou um crescente intervencionismo das monarquias ibéricas no processo de escolha dos priores peninsulares, como ocorreu, por exemplo, em Portugal e em Castela, desde o século XIV, mas principalmente no seguinte.

apoiaram na fundação de uma nova dinastia. Além disso, já na época de D. Afonso V, apesar de tentativas de delimitação dos poderes concorrentes da nobreza senhorial, ainda percebe-se certa tensão nas relações envolvendo aristocracias e Coroa. Será no decorrer do século XVI que essa disputa de poder terá como lado claramente mais favorecido a Monarquia Portuguesa, o que consolida um processo de centralização descontínuo iniciado com Afonso II (RAMOS, SOUSA E MONTEIRO, 2010, pp. 167-169). 
Durante o reinado de D. Afonso V, após um período de conflitos entre a Ordem do Hospital e a Coroa portuguesa ${ }^{90}$, houve uma reaproximação entre hospitalários e monarquia. Em 1453, D. Afonso V confirmou duas cartas outorgadas pelos reis antecessores, nas quais era determinado que as justiças régias deveriam executar as diretrizes estipuladas pelo prior, quando as questões se relacionassem às pessoas da Ordem $^{91}$.

Nessa conjuntura, observamos a concessão de vários privilégios a membros da Ordem do Hospital e a pessoas ligadas aos hospitalários ${ }^{92}$, geralmente isenções econômicas e de prestação de serviços ${ }^{93}$, doações ${ }^{94}$, cartas de perdão $^{95}$, aposentações $^{96}$ e legitimações $^{97}$. Além disso, a Ordem do Hospital conseguiu do monarca português nomeações ${ }^{98}$ para cargos públicos para membros da casa prioral, o que favoreceu imensamente o Prior Vasco de Ataíde, que substituíra seu irmão João de Ataíde no Priorado. Vale ressaltar que a clientela desses priores também foi imensamente agraciada com tais benefícios, principalmente com relação a cartas de perdão, como veremos no próximo tópico desta tese.

De acordo com António Maria Falcão Pestana de Vasconcelos (2008, p. 108):

A intervenção por parte da Coroa na Ordem do Hospital irá também fazer-se sentir a outros níveis, influenciando directamente o dia a dia desta

\footnotetext{
${ }^{90}$ Referímo-nos à questão do apoio dos Hospitalários à causa da viúva Dona Leonor, a qual havia recebido, através do testamento de Dom Duarte, a regência do reino de Portugal. Na ocasião da fuga de D. Leonor para Castela, esteve acompanhada pelo então Prior do Crato, D. Nuno Gonçalves de Góis. Sobre esta questão ver COSTA, 2000, pp. 203-206 e VASCONCELOS, 2008, p. 113.

${ }^{91}$ A.N.T.T., Leitura Nova, Guadiana, I. 3, fólios 160v-161.

${ }_{92}$ Exemplo de carta de privilégio a uma pessoa relacionada à Ordem do Hospital foi concedida a Estevão Lourenço, apresentando o perdão do degredo para Ceuta e justiça régia, sob condição de pagar 500 reais para a chancelaria régia. COSTA, 2000, p. 214.

${ }^{93}$ Um exemplo de privilégio de isenção econômica e de prestação de serviço é a carta de 17 de março de 1450 , através da qual o rei isenta quarenta homens que morassem e povoassem Vera Cruz de Marmelar, isentando-os do pagamento de peitas, fintas, talhas, pedidos e empréstimos e outros encargos, lançados tanto pelos reis como pelos outros concelhos. A.N.T.T., Gaveta VI, m. ún, nº 34. VASCONCELOS, 2008, p. 107.

${ }_{94}$ Exemplo de carta de doação é a que, através da qual, em 10 de março de 1452, D. Afonso V doou vitaliciamente a Fr. Vasco de Oliveira, comendador de Coimbra e de S. João de Corveira, a renda do pão de Penela, do reguengo de Campores e a rendo do relego da vila de Penela. A.N.T.T., Chancelaria de D. Afonso V, Liv. 12, fl. 26v. COSTA, 2000, p. 218. Outro exemplo é a doação ao Prior do Crato de uma naveta e os bens que haviam pertencido a Afonso Fernandes, bem como os de seus parceiros. A.N.T.T., Gavetas VI, m. ún., no 87.

${ }^{95}$ Alguns exemplos de cartas de perdão: A.N.T.T., Chancelaria de D. Afonso V, Liv. 21, fl. 96v; Liv. 21, fl. 22; Liv. 22, fl. 86, Liv. 22, fls. 66-66v; Liv. 28, fl. 54; Liv. 22, fl. 123; Liv. 22, fl. 108; Liv. 8, fl. 188; Liv. 13, fl. 69 v, Liv. 4, fl. 33v; Liv. 12, fl.67v; Liv. 24, fl. 92. Algumas dessas cartas de perdão foram listadas no próximo tópico desta tese.

${ }^{96}$ Um exemplo de carta de aposentação é a de 2 de dezembro de 1465, através da qual João Carvalho, a pedido do Fr. Luís Pedrosa, cavaleiro da Ordem, recebe aposentação pela idade de 70 anos. A.N.T.T., Chancelaria de D. Afonso V, Liv. 4, fl. 48v; VASCONCELOS, 2008, p. 107.

${ }^{97}$ Exemplos de legitimações: A.N.T.T., Chancelaria de D. Afonso V, Liv. 3, fl. 61v; Leitura Nova, Legitimações, Liv. 2, fls. 25v-26; Liv. 2, fls. 14v-15; Liv. 2, fl. 77; Liv. 1, fl. 290; Liv. 2, fl. 135; Liv. 1, fls. 259-259 v.

${ }^{98}$ Alguns exemplos de nomeações: A.N.T.T., Chancelaria de D. Afonso V, Liv. 10, fl. 88v; Liv. 12, fl. 36; Liv. 26, fl. 9; Liv. 30, fls. 3v, 21, 52, 48v, 70v. Algumas dessas cartas de nomeações foram listadas no próximo tópico desta tese.
} 
instituição. Neste sentido, a Coroa irá marcar a sua posição em áreas tão diversas como as económicas e administrativas, judiciais e jurisdicionais.

D. Afonso V ainda convidou o já Prior do Crato, D. Vasco de Ataíde, para ser padrinho de seu filho, o príncipe D. João (que viria a se tornar o rei D. João II). O convite também fora feito a D. Fernando, Duque de Bragança, o que de fato comprova a proximidade de D. Vasco de Ataíde do monarca ${ }^{99}$.

Todo esse contexto acabava por exigir da Ordem do Hospital sua contraprestação, principalmente na integração das forças militares régias que lutavam no litoral da África. Essa parceria bélica era incentivada pela Santa Sé, conforme consta na bula Etsi cuncti, de Calisto III, expedida em 15 de fevereiro de 1456, que exigia que todas as ordens militares existentes em Portugal, inclusive a Ordem de São João, fundassem e mantessem, às suas próprias custas, um convento na cidade de Ceuta ${ }^{100}$. Sobre isso, falaremos mais no próximo capítulo.

Citando Pestana de Vasconcelos (2008, pp. 109-110):

A presença da Ordem do Hospital no Norte de África concretizar-se-á logo em Março de 1456, com a entrega de 114 moios e 34 alqueires de trigo para abastecimento da cidade de Ceuta ${ }^{101}$, e mais tarde em 1471, na conquista da praça de Arzila. Esta última, terá contribuído para que o prior do Hospital, requeresse ao monarca, para a sua Ordem, os mesmos privilégios concedidos à Milícia de Cristo, o que veio a acontecer a 22 de Outubro de $1471^{102}$.

Segundo José Anastásio de Figueiredo Ribeiro (1800, p. 65), D. Vasco de Ataide só não participou da primeira cruzada de D. Afonso V, em 1458, porque talvez estivesse servindo a Ordem na ilha de Rodes e afirma que D. Vasco de Ataíde fora aliado militar da monarquia portuguesa nas conquistas de Arzila e Tanger (1471), tendo delas participado pessoalmente, e que é quase certo que também participara dos conflitos na Batalha de Toro (1476), com os Reis Católicos ${ }^{103}$.

Não se póde apurar, nem sera líquido quando para o Reino voltaria, pelo menos, o tantas vezes nomeado Prior D Vasco de Athaîde: pois unicamente apparece, que elle, e muitos Comendadores da sua Ordem acompanham tambem o Sr. Rei D. Affonso V. na terceira gloriosa jornada á Africa sobre

\footnotetext{
${ }^{99}$ A.N.T.T., Gaveta XX, maço 6, número 15. Monumenta Henricina, Vol. 12, doc. 68. Crónica de D. João II, de Garcia de Resende, Cap. 2, pp. 2-3.

${ }^{100}$ Monumenta Henricina, Vol. XII, doc. 116, pp. 225-229. A.N.T.T., Bulas, m. 27, nº 12; COSTA, 2000 , p. 219.

${ }^{101}$ Nota do autor: IAN/TT., Chancelaria de D. Afonso V, Liv. 1, fl. 82. Pub. Ch.R., tomo II, doc. 19, pp. 669709.

102 Nota do autor: IAN/TT., Chancelaria de D. Afonso V, Liv. 22, fl. 73. Ref. por P. COSTA, 1999-2000, p. 219.

${ }^{103}$ Maior discussão sobre isso no próximo capítulo desta tese. Por isso, não indicamos aqui a documentação relacionada.
} 
Arzilla, aonde chegaram em 20, e a tormaram a 24 de Agosto do anno de 1471; sem embargo do silencio, que se encontra nas Chronicas a respeito da Ordem de Malta (RIBEIRO, 1800, p. 76).

Talvez, a ocasião da conquista de Arzila, tenha sido o momento de maior proximidade entre o Prior do Crato e D. Afonso V. Na tomada dessa praça africana, D. Vasco de Ataíde teve um papel de destaque, o que o permitiu, posteriormente, solicitar ao monarca que concedesse à Ordem do Hospital os mesmos privilégios de que gozava a Ordem de Cristo, o que a aconteceu em 22 de outubro de 1471 e depois foi confirmado em 5 de janeiro de 1478 (COSTA, 2000, p. 276) $)^{104}$.

Vale ainda observar que de fato havia confiança da Coroa no Priorado do Crato, tanto é que foi o próprio Prior D. Vasco de Ataíde o escolhido pelo monarca para prover e armar no Porto a armada na qual D. Afonso V viajaria para o reino Franco, a fim de requerer apoio militar de Luís XI na sua luta contra Castela (COSTA, 2000, p. 220). No próximo capítulo, demonstraremos como é bem provável que Vasco de Ataíde tenha até ido junto com o monarca se encontrar com o rei francês.

Diante dessas explicações, poderíamos ser levados a pensar que o ambiente do reino era sempre de paz entre o Hospital e a Coroa, porém, não era sempre que os interesses de ambos convergiam ${ }^{105}$. Vejamos, por exemplo, o que disse Paula Pinto Costa a respeito desses momentos de menor colocaboração (COSTA, 2000, p. 221):

Apesar deste ambiente de colaboração entre o rei e a Ordem parece
dominante durante o reinado de Afonso V, surgiram momentos em que os
interesses de ambos não coincidiram. Quando assim aconteceu, é possível
que estivessem em causa, acima de tudo, os diversos poderes senhoriais e
não uma intenção, marcadamente, contra os Hospitalários portugueses, como
decorre do exemplo que passamos a referir. Assim, em 1452, foi ditada uma
sentença favorável à comenda de Leça e contra o Prior João de Ataíde, sobre

${ }^{104}$ Sobre isso, A.N.T.T., Chancelaria de D. Afonso V, Liv. 22, fl. 73. Leitura Nova, Guadiana, Liv. 6, fls. 7171v e Liv. 4, f. 108. Gavetas VI, m. ún. no 164 e 184. Monumenta Henricina, Vol. 15, doc. 23, pp. 23-24. Livro dos Forais..., Vol. 3, doc. 291, pp. 23-55.

${ }^{105}$ Exemplo de discórdia entre o Priorado do Crato e a monarquia aparece em A.N.T.T., Chancelaria de D. Afonso V, Liv. 15, fls. 43-43v e 82v. Segundo Paula Pinto Costa (2000, p. 221): "Um outro episódio pode ser relembrado, quando procuramos identificar os sintomas de algum momento de menor colaboração entre o rei e a Ordem do Hospital. Referimo-nos ao privilégio régio concedido a Diogo da Silveira, conselheiro do rei, seu escrivão da puridade e vedor mor das obras régias, e que dizia respeito ao contrato de emprazamento em três vidas da vila de Pedrogão Pequeno, feito por D. Vasco de Ataíde. Através desta benesse, Diogo da Silveira ficava autorizado a dar a outras pessoas, terras, herdades, bens, vinhas, casas e pardieiros, que não tivessem sido aproveitados, isto depois de ter passado um ano sobre o respectivo pregão, na tentativa de que os seus donos se incumbissem da exploração dessas propriedades. Como já ficou mencionado, o senhorio destes bens era a Ordem de S. João, representada pelo seu Prior, o que, sem dúvida, faz pensar que D. Afonso V, com esta medida, fazia perigar a titulatura da Ordem sobre estes mesmos bens. 
um diferendo centrado no padroado da igreja de S. Vicente de Tougues, na terra da Maia ${ }^{106}$.

Analisando a relação entre o Priorado do Crato e o rei D. João II, António Maria Pestana de Vasconcelos escreveu o seguinte (2008, p. 110):

Desta feita, os sucessivos monarcas, ou quem por eles momentaneamente exerceu o poder, tiveram sempre uma particular atenção na indigitação e nomeação dos governadores das Ordens de Avis, Santiago e Cristo, e na do prior do Crato, para a Ordem do Hospital. Se num primeiro momento, estas funções ainda foram exercidas por elementos não pertencentes à Família Real, a curto prazo esta prática passou a ser impensável, face à política centralizadora cada vez mais assumida por estes soberanos. Assim sendo, a entrega do governo e administração das Ordens Militares passava obrigatoriamente pelos Infantes, membros da Família Real, e preferencialmente pelos filhos de reis. Quando tal não acontecia - como na Ordem do Hospital - estas nomeações tinham sempre em conta a proximidade do indigitado face ao monarca, chegando mesmo a criarem-se laços de afinidade, como aconteceu por exemplo, com D. Vasco de Ataíde ao ser um dos escolhidos para padrinho do futuro D. João II.

Já o rei D. João II iniciou seu relacionamento com os hospitalários de Portugal diminuindo certos privilégios e limitando a própria influência dos freires sobre as pessoas do reino ${ }^{107}$. Estava em execução um plano de autoridade anti-senhorial, no qual as ordens militares deveriam ser enquadradas.

Apesar disso, Dom João II, durante seu governo, confirmou vários benefícios de seus antecessores, como o quadro geral de privilégios régios outorgados aos freires desde a fundação do reino ${ }^{108}$. Talvez, os ideais expansionistas marítimos de D. João II, unidos aos laços afetivos com D. Vasco de Ataíde, resultaram numa relação de cordialidade deste rei com a Ordem do Hospital.

Até o reinado de D. João II, os privilégios da Ordem do Hospital tiveram tanto aspecto jurisdicional quanto econômico. Durante séculos, a Ordem foi recebendo confirmações gerais dos privilégios de que usufruía.

Ainda segundo Pestana Vasconcelos (2008, p. 117):

\footnotetext{
${ }^{106}$ Nota da autora: A.D.P., Bailiagem de Leça, $\mathrm{n}^{\mathrm{o}} 3595$, fls. 31 e seguintes.

107 A.N.T.T., Leitura Nova, Além Douro, Liv. 1, fl. 180 e fl. 117v. COSTA, 2000, p.222.

108 A.N.T.T., Leitura Nova, Guadiana, Liv. 1, fls. 122-127. Livro dos Forais, Vol. 3, doc. 292. COSTA, 2000, p. 224 .
} 
Neste sentido, refira-se à confirmação à Ordem de todos os privilégios anteriormente atribuídos desde a fundação da nacionalidade ${ }^{109}$, o privilégio concedido aos caseiros, lavradores e moradores das terras da Ordem, isentando-os de prestarem serviços nas obras dos muros e castelos ${ }^{110}$, a doação concedida ao prior do Crato, D. Vasco de Ataíde, dos dízimos das sentenças proferidas nas terras do priorado $^{111}$, e as várias cartas de legitimação atribuídas a filhos de membros desta milícia ${ }^{112}$, estas últimas reveladores do seu poder soberano - atributo exclusivo do monarca conceder legitimação de paternidade de terceiros ${ }^{113}$.

Em 1492, no final do reinado de D. João II, um novo prior ascende à dignidade máxima dentro do Priorado do Crato, seu nome é D. Diogo Fernandes de Almeida, filho de Lopo de Almeida, $1^{\circ}$ conde de Abrantes, a quem já nos referimos anteriormente. A família Almeida era bastante ligada à Corte Portuguesa, tanto é que será o Prior do Crato o escolhido pelo rei para velar pelo cumprimento de suas cláusulas testamentárias, como se pode observar em seu testamento de 29 de setembro de $1495^{114}$.

\subsection{VASCO DE ATAÍDE E SUA CLIENTELA}

É importante frisar que uma das malhas de poder nas quais inseria-se D. Vasco de Ataíde era aquele emaranhado de relações sociais que ele mantinha com seus ditos "clientes", ou seja, sua clientela.

No entanto, uma pesquisa aprofundada sobre as pessoas com as quais tal Prior se relacionava torna-se complicada, tendo em vista a escassez documental sobre o assunto. Já

\footnotetext{
${ }^{109}$ Nota do autor: IAN/TT, Leitura Nova, Guadiana, Liv. 1, fls. 122-127; Pub. Livro dos Forais, vol. 3, doc. 292, pp. 25-36. Ref. P. COSTA, 1999/2000, p. 224.

${ }_{110}$ Nota do autor: IAN/TT, Gaveta VI, maço único, no 95 e IAN/TT, Leitura Nova, Guadiana, Liv. 4, fls. 271v272; IAN/TT, Leitura Nova, Beiras, Liv. 1, fls. 149-149v. Ref. P. COSTA, 1999/2000, p. 224.

${ }^{111}$ Nota do autor: IAN/TT, Gaveta VI, maço único, nº 188 e IAN/TT, Leitura Nova, Guadiana, Liv. 4, fls. 194v195v. Sobre a justiça no reinado de D. João II, veja-se M. MENDONÇA, 1995, pp. 313-328.

112 Nota do autor: Sobre as várias cartas de legitimação concedidas pelo monarca a pessoas directamente relacionadas com a Ordem do Hospital, veja-se P. COSTA, 1999/2000, p. 225, Tabela 22.

${ }^{113}$ Nota do autor: Sobre legitimação em Portugal, veja-se MORENO, 1967.

${ }^{114}$ Segundo Paula Pinto Costa (2000, p. 226): "Publ. SOUSA, Caetano de - Provas da Historia Genealogica..., 1.IV, t. II, parte I, pp. 206-217. Este testamento foi confirmado e ratificado em 30 de setembro de 1495, sendo D. Diogo Fernandes de Almeida uma das testemunhas que o validaram, e D. João II viria a falecer no Algarve a 25 de Outubro do mesmo ano. D. Diogo Fernandes de Almeida era membro de uma família - a dos Almeida importante em termos políticos e foi um homem que conseguiu contar com a confiança do monarca, fazendo-lhe companhia na fase final da sua vida (RESENDE, Garcia de - Crónica de D. João II, cap. 210, pp. 277-279, cap. 211, pp. 280-282 e cap. 213, pp. 285-286). A este Prior do Crato foi entregue o bastardo régio, D. Jorge, para que o criasse e educasse (PINA, Rui de - Crónica de D. João II, cap. 80, 81 e 83 e RESENDE, Garcia de Crónica de D. João II, cap. 216, cap. 288-289 e cap. 137, p. 206, constituído aio e governador da casa de D. Jorge, a 12 de Abril de 1492 e FREIRE, A. Braamcamp - Brasões da Sala Sintra, vol. II, pp. 361-362...”
} 
apresentamos em capítulos anteriores desta tese os motivos pelos quais não há um cartório da Ordem do Hospital em Portugal referente ao período medieval. Talvez, simplesmente, tais documentos nunca tenham existido, ou tenham sido mesmo destruídos, como explicamos anteriormente. O que temos são documentos que associam o Prior a determinados atos jurídicos: testamentos, doações, vendas, permutas, sentenças, emprezamentos, etc.

Em uma de suas várias obras acerca da Ordem do Hospital em Portugal, Paula Pinto Costa conseguiu apresentar um rol dos principais clientes de D. Vasco de Ataíde, o que apresentaremos a seguir, em forma de planilha ${ }^{115}$, tencendo comentários ao final (2000, pp. 277-283). Algumas informações constam também das obras de Braamcamp Freire (1960, pp. 425-438) e de Manuel Lopes de Almeida (1960, pp. 275-276), respectivamente o Archivo Historico Portuguez e a Monumenta Henricina. Além desses dois autores, preferimos também apresentar a cota arquivística de documentos manuscritos que se referem a tais informações, quando isso nos foi possível fazer ${ }^{116}$.

Tabela 1 - Clientela de D. Vasco de Ataíde

\begin{tabular}{|c|c|c|}
\hline CLIENTE & INFORMAÇÃO OBTIDA & $\begin{array}{c}\text { REFERÊNCIA } \\
\text { DOCUMENTAL }\end{array}$ \\
\hline Afonso Fernandes & $\begin{array}{l}\text { Era escudeiro do Prior do Hospital e } \\
\text { morador na Pederneira, quando em } 28 \text { de } \\
\text { maio de } 1468 \text {, D. Afonso V lhe perdoou a } \\
\text { justiça régia, face à acusação de ter } \\
\text { deixado fugir da prisão uma mulher velha } \\
\text { e viúva, tendo que pagar } 500 \text { reais } \\
\text { brancos para a Piedade. }\end{array}$ & $\begin{array}{l}\text { A.N.T.T., Chancelaria de } \\
\text { D. Afonso V, Liv. } 28 \text {, fl. } \\
108 .\end{array}$ \\
\hline Afonso Vasques & $\begin{array}{l}\text { Era escudeiro do Prior do Hospital e, em } \\
15 \text { de dezembro de } 1462 \text {, foi privilegiado } \\
\text { com a nomeação para o cargo de } \\
\text { requeredor das sisas e direitos que o rei } \\
\text { tinha na vila da Amieira. }\end{array}$ & $\begin{array}{l}\text { A.N.T.T., Chancelaria de } \\
\text { D. Afonso V, Liv. 1, fl. } \\
\text { 128v. }\end{array}$ \\
\hline Álvaro de França & $\begin{array}{l}\text { Em } 4 \text { de dezembro de } 1480 \text {, enquanto } \\
\text { moço de estrebaria do Prior do Crato, } \\
\text { aparece referido na carta de quitação a } \\
\text { Pero Estaço, recebedor mor dos dinheiros } \\
\text { outorgados pelos povos a D. Afonso V, } \\
\text { tendo emprestado ao rei } 3 \text { mil reais. }\end{array}$ & $\begin{array}{l}\text { FREIRE, } r \text { Anselmo } \\
\text { Braamcamp. Os sessenta } \\
\text { milhões outorgados em } \\
\text { 1478. In Archivo Historico } \\
\text { Portuguez. Vol. IV. } \\
\text { Lisboa: } 1960 \text {, pp. 425-438. }\end{array}$ \\
\hline
\end{tabular}

${ }^{115}$ A planilha é formatação nossa.

${ }^{116}$ Os documentos citados neste capítulo foram quase todos consultados durante o tempo em que estivemos em Portugal analisando e providenciando fotocópias e digitalizações de documentos manuscritos, no segundo semestre de 2013. Com as digitalizações, tivemos tempo para analisar já no Brasil quase toda a parte que faltava. Alguns já haviam sido analisados durante os anos de Mestrado em História Medieval na Universidade do Porto. Esta é uma pesquisa que teve início em 2008. 


\begin{tabular}{|c|c|c|}
\hline Álvaro Martins & $\begin{array}{l}\text { Era escudeiro do Prior do Crato e, em } 2 \\
\text { de novembro de } 1471 \text {, foi nomeado para } \\
\text { o cargo de escrivão dos órfãos das vilas } \\
\text { de Santarém e Pedrogão Pequeno e seus } \\
\text { termos, em substituição de Estevão Eanes } \\
\text { de Abrantes, que renunciara ao exercício } \\
\text { do referido cargo por viver no Sardoal, } \\
\text { sendo autorizado a fazer sinal público de } \\
\text { tabelião nas suas escrituras. }\end{array}$ & $\begin{array}{l}\text { A.N.T.T., Chancelaria de } \\
\text { D. Afonso V, Liv. } 22 \text {, fls. } \\
111 \mathrm{v}-112 .\end{array}$ \\
\hline Álvaro Rodrigues & $\begin{array}{l}\text { Em } 4 \text { de dezembro de } 1480 \text {, enquanto } \\
\text { moço de estrebaria do Prior do Crato, } \\
\text { aparece referido na carta de quitação a } \\
\text { Pero Estaço, recebedor mor dos dinheiros } \\
\text { outorgados pelos povos a D. Afonso V, } \\
\text { tendo emprestado ao rei } 5 \text { mil reais. }\end{array}$ & 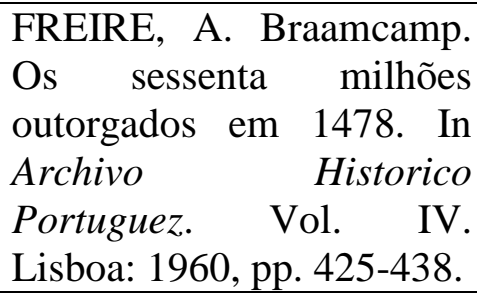 \\
\hline Álvaro da Sertã & $\begin{array}{l}\text { Era escudeiro do Prior do Crato e, em } 8 \\
\text { de fevereiro de } 1481 \text {, foi nomeado para o } \\
\text { cargo de escrivão das sisas régias do } \\
\text { Crato, em substituição de Vicente Eanes } \\
\text { que morrera. }\end{array}$ & $\begin{array}{l}\text { A.N.T.T., Chancelaria de } \\
\text { D. Afonso V, Liv. 26, fl. } 9 .\end{array}$ \\
\hline Antão Afonso & $\begin{array}{l}\text { Era escrivão da puridade de D. Vasco de } \\
\text { Ataíde, Prior da Ordem do Hospital, e foi } \\
\text { nomeado pelo rei para o cargo de } \\
\text { escrivão dos feitos da Ordem, em } \\
\text { substituição de Gonçalo Eanes. }\end{array}$ & $\begin{array}{l}\text { A.N.T.T., Chancelaria de } \\
\text { D. Afonso V, Liv. 4, fl. } \\
\text { 74v. }\end{array}$ \\
\hline Antão Delgado & $\begin{array}{l}\text { Em } 4 \text { de dezembro de } 1480 \text {, enquanto } \\
\text { moço de estrebaria do Prior do Crato, } \\
\text { aparece referido na carta de quitação a } \\
\text { Pero Estaço, recebedor mor dos dinheiros } \\
\text { outorgados pelos povos a D. Afonso V, } \\
\text { tendo recebido } 500 \text { mil reais para levar a } \\
\text { Campo Maior, com o objetivo de se } \\
\text { pagar o soldo dos homens de pé. }\end{array}$ & $\begin{array}{l}\text { FREIRE, A. Braamcamp. } \\
\text { Os sessenta milhões } \\
\text { outorgados em } 1478 . \text { In } \\
\text { Archivo } \\
\text { Portuguez. Historico } \\
\text { Lisboa: } 1960, \text { pol. } 425-438 .\end{array}$ \\
\hline António Vasques & $\begin{array}{l}\text { Era escudeiro do Prior do Crato e, em } 19 \\
\text { de novembro de } 1471 \text {, recebeu o perdão } \\
\text { da justiça régia, por ter agredido e ferido } \\
\text { Diogo Serrão, escolar, morador em } \\
\text { Lisboa, em virtude do perdão geral } \\
\text { concedido aos homiziados da armada e } \\
\text { tomada de Arzila e do perdão do lesado. }\end{array}$ & $\begin{array}{l}\text { A.N.T.T., Chancelaria de } \\
\text { D. Afonso V, Liv. } 21 \text {, fl. } \\
\text { 22. }\end{array}$ \\
\hline Dinis Eanes & $\begin{array}{l}\text { Era escudeiro do Prior do Hospital e } \\
\text { morador na cidade de Évora. Em } \\
\text { consequência de uma briga que tivera } \\
\text { com Fernão Toscano tinha-lhe decepado } \\
\text { dois dedos da mão, no entanto, em } 7 \text { de } \\
\text { dezembro de } 1468 \text {, D. Afonso V perdoo- } \\
\text { lhe a justiça régia, a prisão e a respectiva } \\
\text { fuga, contra o pagamento de } 6000 \text { reais } \\
\text { brancos para a Piedade e o perdão das } \\
\text { partes. Passado um mês, ou seja, a } 8 \text { de }\end{array}$ & $\begin{array}{l}\text { A.N.T.T., Chancelaria de } \\
\text { D. Afonso V, Liv. } 28 \text {, fls. } \\
123 \text { e } 124 \mathrm{v} .\end{array}$ \\
\hline
\end{tabular}




\begin{tabular}{|c|c|c|}
\hline & $\begin{array}{l}\text { janeiro do ano seguinte, e em sinal do } \\
\text { restabelecimento das relações entre } \\
\text { ambos, o rei doou-lhe uns pardieiros em } \\
\text { Terena, anteriormente pertencentes a } \\
\text { João do Couto, prior nesta vila, que os } \\
\text { havia comprado sem licença régia. }\end{array}$ & \\
\hline Diogo Dinis & $\begin{array}{l}\text { Era escudeiro do Prior do Crato e } \\
\text { morador na vila de Portalegre. Em } 6 \text { de } \\
\text { dezembro de 1471, D. Afonso V } \\
\text { perdoou-lhe o degredo e a justiça régia } \\
\text { por ter cometido vários delitos, face ao } \\
\text { perdão concedido aos homiziados que } \\
\text { serviram na armada e conquista de Arzila } \\
\text { e Tânger e ao perdão das pessoas } \\
\text { envolvidas. }\end{array}$ & $\begin{array}{l}\text { A.N.T.T., Chancelaria de } \\
\text { D. Afonso V, Liv. 21, fl. } \\
\text { 96v. }\end{array}$ \\
\hline Diogo Fernandes & $\begin{array}{l}\text { Era criado do Prior do Crato, requeredor } \\
\text { do haver do peso, pescado e madeiro na } \\
\text { cidade de Lisboa e, em maio de } 1475 \text {, foi } \\
\text { privilegiado por D. Afonso V, recebendo } \\
\text { autorização para colocar um homem no } \\
\text { exercício dos seus ofícios. }\end{array}$ & $\begin{array}{l}\text { A.N.T.T., Chancelaria de } \\
\text { D. Afonso V, Liv. 30, fl. } \\
\text { 70v. }\end{array}$ \\
\hline Diogo de Praga & $\begin{array}{l}\text { Em } 4 \text { de dezembro de } 1480 \text {, enquanto } \\
\text { moço de estrebaria do Prior do Crato, } \\
\text { aparece referido na carta de quitação a } \\
\text { Pero Estaço, recebedor mor dos dinheiros } \\
\text { outorgados pelos povos a D. Afonso V, } \\
\text { tendo emprestado ao rei } 30 \text { mil reais. }\end{array}$ & $\begin{array}{lr}\text { FREIRE, A. } & \text { Braamcamp. } \\
\text { Os sessenta } & \text { milhões } \\
\text { outorgados em } & \text { 1478. In } \\
\text { Archivo } & \text { Historico } \\
\text { Portuguez. } & \text { Vol. IV. } \\
\text { Lisboa: } 1960, \text { pp. } 425-438 .\end{array}$ \\
\hline Diogo do Sardoal & $\begin{array}{l}\text { Era criado do Prior do Hospital e, em } 4 \\
\text { de novembro de } 1471 \text {, recebeu de D. } \\
\text { Afonso V um casal situado na Ribeira de } \\
\text { Lagomear, o qual havia pertencido a } \\
\text { Diogo Lourenço, juiz ordinário, que o } \\
\text { perdera por o ter comprado sem } \\
\text { autorização do rei. }\end{array}$ & $\begin{array}{l}\text { A.N.T.T., Chancelaria de } \\
\text { D. Afonso V, Liv. 29, fls. } \\
\text { 13-13v. }\end{array}$ \\
\hline Estevão de Braga & $\begin{array}{l}\text { Em } 4 \text { de dezembro de } 1480 \text {, enquanto } \\
\text { escudeiro do Prior do Crato, aparece } \\
\text { referido na carta de quitação a Pero } \\
\text { Estaço, recebedor mor dos dinheiros } \\
\text { outorgados pelos povos a D. Afonso V, } \\
\text { tendo emprestado ao rei } 3 \text { mil reais. }\end{array}$ & $\begin{array}{l}\text { FREIRE, A. Braamcamp. } \\
\text { Os sessenta milhões } \\
\text { outorgados em } 1478 . \text { In } \\
\text { Archivo } \\
\text { Portuguez. Historico } \\
\text { Lisboa: } 1960, \text { pp. } 425-438 .\end{array}$ \\
\hline Fernão Caldeira & $\begin{array}{l}\text { Era escudeiro do Prior do Hospital e } \\
\text { morador de Elvas. Em } 22 \text { de outubro de } \\
\text { 1471, D. Afonso V perdoou-lhe a justiça } \\
\text { régia, em função do perdão outorgado aos } \\
\text { homiziados que serviram na armada e } \\
\text { conquista de Arzila e Tânger e do perdão } \\
\text { das partes, por ter deixado fugir da prisão } \\
\text { Fernão Martins Rebelo, sendo este, por } \\
\text { sua vez, acusado da morte de Lourenço } \\
\text { Gonçalves Trepilhos. }\end{array}$ & $\begin{array}{l}\text { A.N.T.T., Chancelaria de } \\
\text { D. Afonso V, Liv. 22, fl. } \\
\text { 54. }\end{array}$ \\
\hline
\end{tabular}




\begin{tabular}{|c|c|c|}
\hline $\begin{array}{l}\text { Fernão Lopes } \\
\text { Barregua }\end{array}$ & $\begin{array}{l}\text { Era escudeiro do Prior do Hospital e } \\
\text { morador em Beja e, em } 28 \text { de outubro de } \\
1471 \text {, D. Afonso V perdoou-lhe a justiça } \\
\text { régia, em consequência do perdão geral } \\
\text { concedido aos homiziados que serviram } \\
\text { na armada e conquista das praças de } \\
\text { Arzila e Tânger e do perdão das partes, } \\
\text { por ter ferido David Cafa, judeu. }\end{array}$ & $\begin{array}{l}\text { A.N.T.T., Chancelaria de } \\
\text { D. Afonso V, Liv. 22, fls. } \\
66-66 \mathrm{v} .\end{array}$ \\
\hline Fernão Penteado & $\begin{array}{l}\text { Em } 4 \text { de dezembro de } 1480 \text {, enquanto } \\
\text { escudeiro do Prior do Crato, aparece } \\
\text { referido na carta de quitação a Pero } \\
\text { Estaço, recebedor mor dos dinheiros } \\
\text { outorgados pelos povos a D. Afonso V, } \\
\text { tendo emprestado ao rei } 30 \text { mil reais. }\end{array}$ & $\begin{array}{lr}\text { FREIRE, A. Braamcamp. } \\
\text { Os sessenta milhões } \\
\text { outorgados em } & \text { 1478. In } \\
\text { Archivo } & \text { Historico } \\
\text { Portuguez. } & \text { Vol. IV. } \\
\text { Lisboa: } 1960, \text { pp. } 425-438 .\end{array}$ \\
\hline Fernão Vaz & $\begin{array}{l}\text { Em } 4 \text { de dezembro de } 1480 \text {, enquanto } \\
\text { moço de estrebaria do Prior do Crato, } \\
\text { aparece referido na carta de quitação a } \\
\text { Pero Estaço, recebedor mor dos dinheiros } \\
\text { outorgados pelos povos a D. Afonso V, } \\
\text { tendo emprestado ao rei } 40 \text { mil reais. }\end{array}$ & 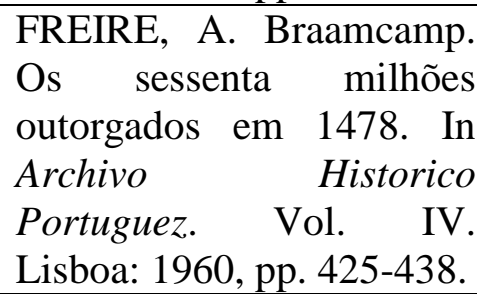 \\
\hline Filipe Rodrigues & $\begin{array}{l}\text { Era escudeiro do Prior e morador no } \\
\text { Crato, quando, em } 22 \text { de outubro de } \\
1468 \text {, D. Afonso V o nomeou para o } \\
\text { cargo de juiz das sisas régias, a exercer } \\
\text { na referida vila, em substituição de } \\
\text { Fernão Gonçalves Serra que morrera. }\end{array}$ & $\begin{array}{l}\text { A.N.T.T., Chancelaria de } \\
\text { D. Afonso V, Liv. 28, fl. } \\
119 \mathrm{v} .\end{array}$ \\
\hline Gaspar Domingues & $\begin{array}{l}\text { Em } 4 \text { de dezembro de } 1480 \text {, enquanto } \\
\text { moço de estrebaria do Prior do Crato, } \\
\text { aparece referido na carta de quitação a } \\
\text { Pero Estaço, recebedor mor dos dinheiros } \\
\text { outorgados pelos povos a D. Afonso V, } \\
\text { tendo recebido } 8 \text { mil reais. Recebeu ainda } \\
\text { a quantia de } 6910 \text { reais, por mão de } \\
\text { Diogo Leitão, em virtude de } 18 \text { mil reais } \\
\text { que tinha levado a Campo Maior, para } \\
\text { pagamento do soldo dos homens de pé. }\end{array}$ & $\begin{array}{l}\text { FREIRE, A. Braamcamp. } \\
\text { Os sessenta milhões } \\
\text { outorgados em } 1478 . \text { In } \\
\text { Archivo } \\
\text { Portuguez. Historico } \\
\text { Lisboa: } 1960 \text {, pol. } 425-438 .\end{array}$ \\
\hline Gil Machado & $\begin{array}{l}\text { Era escudeiro do Prior do Hospital e } \\
\text { morador em Portalegre. D. Afonso V } \\
\text { concedeu-lhe o perdão de quatro anos de } \\
\text { degredo em Ceuta e a prisão, na } \\
\text { sequência do perdão geral outorgado aos } \\
\text { homiziados na armada e conquista de } \\
\text { Arzila e Tânger, por libertar um preso da } \\
\text { cadeia. Em } 11 \text { de outubro de } 1475 \text { foi } \\
\text { nomeado vitaliciamente para o cargo de } \\
\text { escrivão da coudelaria de Portalegre. }\end{array}$ & $\begin{array}{l}\text { A.N.T.T., Chancelaria de } \\
\text { D. Afonso V, Liv. 22, fl. } \\
\text { 86; Liv. 30, fl. 3v. }\end{array}$ \\
\hline Gonçalo Anes & $\begin{array}{l}\text { Em } 4 \text { de dezembro de } 1480 \text {, enquanto } \\
\text { criado do Prior do Crato, aparece referido } \\
\text { na carta de quitação a Pero Estaço, } \\
\text { recebedor mor dos dinheiros outorgados }\end{array}$ & 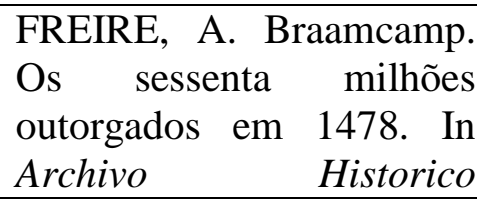 \\
\hline
\end{tabular}




\begin{tabular}{|c|c|c|}
\hline & $\begin{array}{l}\text { pelos povos a } \mathrm{D} \text {. Afonso } \mathrm{V} \text {, tendo } \\
\text { emprestado ao rei } 40 \text { mil reais. }\end{array}$ & $\begin{array}{l}\text { Portuguez. Vol. IV. } \\
\text { Lisboa: } 1960, \text { pp. } 425-438 .\end{array}$ \\
\hline Gonçalo Gil & $\begin{array}{l}\text { Em } 25 \text { de junho de } 1454 \text {, era escudeiro } \\
\text { do Prior do Crato e foi nomeado, por um } \\
\text { período de cinco anos, para o cargo de } \\
\text { coudel da vila da Sertã e da comenda de } \\
\text { Belver, em substituição de Estevão Eanes } \\
\text { de Abrantes, cujo tempo de exercício do } \\
\text { cargo havia terminado. }\end{array}$ & $\begin{array}{l}\text { A.N.T.T., Chancelaria de } \\
\text { D. Afonso V, Liv. 10, fl. } \\
\text { 73. }\end{array}$ \\
\hline Henrique Ribeiro & $\begin{array}{l}\text { Era escudeiro do Prior do Hospital, } \\
\text { morador na vila do Crato e, em } 12 \text { de } \\
\text { junho de } 1466 \text {, foi nomeado por D. } \\
\text { Afonso V para o cargo de procurador na } \\
\text { referida localidade. }\end{array}$ & $\begin{array}{l}\text { A.N.T.T., Chancelaria de } \\
\text { D. Afonso V, Liv. 14, fl. } \\
\text { 85. }\end{array}$ \\
\hline João Álvares & $\begin{array}{l}\text { Era escudeiro do Prior do Hospital e } \\
\text { morador no Porto, quando em } 21 \text { de } \\
\text { outubro de 1471, D. Afonso V lhe } \\
\text { concedeu carta de privilégio, por estar } \\
\text { pronto para servir na guerra com as suas } \\
\text { bestas e armas. O privilégio era extensivo } \\
\text { a todos os seus caseiros, amos, } \\
\text { mordomos, apaniguados e lavradores que } \\
\text { estivessem nas suas terras e consistia na } \\
\text { isenção do pagamento de impostos e } \\
\text { encargos concelhios, de ir com presos e } \\
\text { dinheiros, bem como de serem tutores e } \\
\text { curadores. Em } 4 \text { de dezembro de } 1480 \text {, } \\
\text { enquanto mercador e escudeiro do Prior } \\
\text { do Crato, morador na cidade do Porto, } \\
\text { aparece referido na carta de quitação a } \\
\text { Pero Estaço, recebedor mor dos dinheiros } \\
\text { outorgados pelos povos a D. Afonso V, } \\
\text { tendo emprestado ao rei a quantia de } 60 \\
\text { mil reais. }\end{array}$ & $\begin{array}{l}\text { A.N.T.T., Chancelaria de } \\
\text { D. Afonso V, Liv. 22, fl. } \\
\text { 127v. } \\
\text { FREIRE, A. Braamcamp. } \\
\text { Os sessenta milhões } \\
\text { outorgados em } 1478 \text {. In } \\
\text { Archivo } \\
\text { Portuguez. Historico } \\
\text { Lisboa: } 1960, \text { pp. } 425-438 .\end{array}$ \\
\hline João Barbudo & $\begin{array}{l}\text { Era escudeiro do Prior do Crato e, após } \\
26 \text { de setembro de } 1475 \text {, deveria exercer } \\
\text { apenas um dos ofícios até aí } \\
\text { desempenhados por Gil de Paiva, } \\
\text { morador em Cabeço de Vide, isto é, } \\
\text { escrivão das sisas e escrivão dos feitos } \\
\text { das sisas, respeitantes à referida vila, pois } \\
\text { não era legítimo possuir estes dois cargos } \\
\text { em simultâneo. }\end{array}$ & $\begin{array}{l}\text { A.N.T.T., Chancelaria de } \\
\text { D. Afonso V, Liv. 30, fl. } \\
\text { 21. }\end{array}$ \\
\hline João da Costa & $\begin{array}{l}\text { Era escudeiro do Prior do Hospital e foi } \\
\text { escrivão das sacas da comarca de Entre } \\
\text { Tejo e Guadiana, tendo sido substituído } \\
\text { por João Afonso, em } 29 \text { de dezembro de } \\
1474 \text {. }\end{array}$ & $\begin{array}{l}\text { A.N.T.T., Chancelaria de } \\
\text { D. Afonso V, Liv. 30, fl. } \\
\text { 152. }\end{array}$ \\
\hline João Esteves & $\begin{array}{l}\text { Era escudeiro do Prior do Hospital, } \\
\text { morador de Abrantes, e perdeu a posse de }\end{array}$ & $\begin{array}{l}\text { A.N.T.T., Chancelaria de } \\
\text { D. Afonso V, Liv. 29, fl. }\end{array}$ \\
\hline
\end{tabular}




\begin{tabular}{|c|c|c|}
\hline & $\begin{array}{l}\text { bens por ter tido uma relação amorosa } \\
\text { com uma sobrinha, da qual nasceu uma } \\
\text { filha. Estes bens, móveis e de raíz, foram } \\
\text { entregues a Vasco Eanes, escudeiro, } \\
\text { igualmente morador em Abrantes, em } 4 \\
\text { de janeiro de } 1472 \text {. Anteriormente, em } 9 \\
\text { de dezembro de } 1454 \text {, por intermédio do } \\
\text { Prior do Crato, o rei privilegiou um João } \\
\text { Esteves, morador de Lisboa, autorizando- } \\
\text { o a andar em besta muar, o que nos leva a } \\
\text { crer que se tratava da mesma pessoa. }\end{array}$ & 64v; Liv. 10, fl. 125. \\
\hline João da Ponte & $\begin{array}{l}\text { Em } 19 \text { de dezembro de } 1455 \text {, João da } \\
\text { Ponte, escudeiro do Prior do Hospital, foi } \\
\text { nomeado para o exercício do cargo de } \\
\text { escrivão dos dez reais que se recebiam no } \\
\text { almoxarifado de Ponte de Lima, para a } \\
\text { cidade de Ceuta, em substituição de } \\
\text { Diogo Fernandes. }\end{array}$ & $\begin{array}{l}\text { A.N.T.T., Chancelaria de } \\
\text { D. Afonso V, Liv. 15, fl. } \\
\text { 136v. }\end{array}$ \\
\hline João Preto & $\begin{array}{l}\text { Era criado do Prior do Crato e, em } 27 \text { de } \\
\text { julho de } 1463 \text {, foi referido numa carta } \\
\text { régia de privilégio concedida a Álvaro } \\
\text { Gonçalves e a sua mulher. }\end{array}$ & $\begin{array}{l}\text { A.N.T.T., Chancelaria de } \\
\text { D. Afonso V, Liv. 9, fl. } \\
115 .\end{array}$ \\
\hline João Rodrigues & $\begin{array}{l}\text { Em } 4 \text { de dezembro de } 1480 \text {, enquanto } \\
\text { escudeiro do Prior do Crato, aparece } \\
\text { referido na carta de quitação a Pero } \\
\text { Estaço, recebedor mor dos dinheiros } \\
\text { outorgados pelos povos a D. Afonso V, } \\
\text { tendo emprestado ao rei } 20 \text { mil reais. }\end{array}$ & 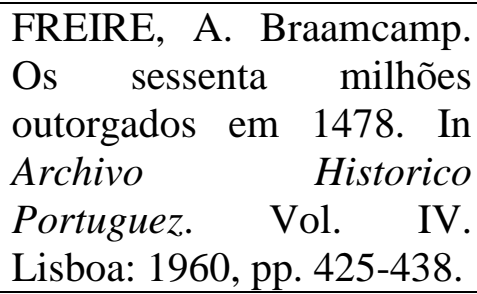 \\
\hline Lopo de Cortes & $\begin{array}{l}\text { Era criado de D. Vasco de Ataíde e, por } \\
\text { volta de 1454, quando se encontrava em } \\
\text { Flandres com o objetivo de comprar } \\
\text { carne, juntamente com Gonçalo } \\
\text { Fernandes, viu-se envolvido num } \\
\text { enfrentamento, dando duas cutiladas em } \\
\text { Gil Vicente, que acabaria por morrer. Em } \\
\text { virtude desta circunstância, em } 16 \text { de } \\
\text { julho de } 1456 \text {, foi agraciado nos termos } \\
\text { do perdão geral, de ir servir durante três } \\
\text { anos em Ceuta, dois dos quais à sua } \\
\text { própria custa. }\end{array}$ & $\begin{array}{l}\text { A.N.T.T., Chancelaria de } \\
\text { D. Afonso V, Liv. 13, fl. } \\
69 \mathrm{v} .\end{array}$ \\
\hline Lopo Dias & $\begin{array}{l}\text { Era escudeiro do Prior do Hospital, } \\
\text { vassalo régio e morador na cidade do } \\
\text { Porto. No ano de } 1465 \text {, foi privilegiado } \\
\text { pelo rei, sendo-lhe conferido o direito de } \\
\text { aposentação pela idade de } 70 \text { anos, com } \\
\text { todas as honras e privilégios próprias dos } \\
\text { vassalos régios }\end{array}$ & $\begin{array}{l}\text { A.N.T.T., Chancelaria de } \\
\text { D. Afonso V, Liv. 14, fl. } \\
\text { 12v. }\end{array}$ \\
\hline Lopo Rodrigues & $\begin{array}{l}\text { Era escudeiro do Prior do Crato e, após } 8 \\
\text { de setembro de } 1475 \text {, deveria exercer um } \\
\text { dos ofícios que até esta data tinham sido }\end{array}$ & $\begin{array}{l}\text { A.N.T.T., Chancelaria de } \\
\text { D. Afonso V, Liv. 30, fl. } \\
\text { 52. }\end{array}$ \\
\hline
\end{tabular}




\begin{tabular}{|c|c|c|}
\hline & $\begin{array}{l}\text { titulados por Aires Afonso, morador no } \\
\text { Alandroal, isto é, escrivão das sisas } \\
\text { régias ou escrivão dos feitos delas na } \\
\text { referida vila. }\end{array}$ & \\
\hline Lopo Vasques & $\begin{array}{l}\text { Era escudeiro do Prior do Hospital e, em } \\
23 \text { de maio de } 1468 \text {, foi nomeado por três } \\
\text { anos para o cargo de coudel em } \\
\text { Portalegre e seu termo, em substituição } \\
\text { de Fernão Martins, que terminara o seu } \\
\text { mandato. }\end{array}$ & $\begin{array}{l}\text { A.N.T.T., Chancelaria de } \\
\text { D. Afonso V, Liv. } 28, \text { fl. } \\
\text { 75. }\end{array}$ \\
\hline Martim Gil & $\begin{array}{l}\text { Em } 15 \text { de abril de } 1455 \text {, Martim Gil, } \\
\text { criado da rainha D. Leonor, escudeiro do } \\
\text { Prior do Crato e vassalo régio, foi } \\
\text { privilegiado por Afonso V, uma vez que } \\
\text { estava pronto para servir com as suas } \\
\text { bestas e armas, sendo autorizados todos } \\
\text { os seus caseiros, mordomos, apaniguados } \\
\text { e lavradores a deslocarem-se para Lisboa } \\
\text { e outros lugares do reino. }\end{array}$ & $\begin{array}{l}\text { A.N.T.T., Chancelaria de } \\
\text { D. Afonso V, Liv. 15, fl. } \\
\text { 24. }\end{array}$ \\
\hline Pero Lopes & $\begin{array}{l}\text { Era escudeiro do Prior do Hospital e, em } \\
23 \text { de janeiro de } 1475 \text {, foi nomeado para } \\
\text { o cargo de tabelião das notas de Lamego, } \\
\text { em substituição de Antão Dias, que } \\
\text { comprara o ofício sem autorização do rei. }\end{array}$ & $\begin{array}{l}\text { A.N.T.T., Chancelaria de } \\
\text { D. Afonso V, Liv. 30, fl. } \\
\text { 153. }\end{array}$ \\
\hline Rui de Melo & $\begin{array}{l}\text { Era criado do Prior do Crato e, em } 22 \text { de } \\
\text { janeiro de } 1464 \text {, recebeu carta de perdão, } \\
\text { em virtude de um pedido feito pelo } \\
\text { referido Prior. Era acusado de ter tirado, à } \\
\text { força, da prisão em Lisboa a mulher de } \\
\text { João do Campo, que havia morado em } \\
\text { Viseu, considerada culpada na morte do } \\
\text { seu marido. Em } 1 \text { de setembro de } 1475 \text {, } \\
\text { enquanto fidalgo da casa do Prior do } \\
\text { Crato, foi nomeado vitaliciamente para o } \\
\text { cargo de coudel da cidade da Guarda. }\end{array}$ & $\begin{array}{l}\text { A.N.T.T., Chancelaria de } \\
\text { D. Afonso V, Liv. 8, fl. } \\
\text { 188; Liv. 30, fl. 48v. } \\
\text { ALMEIDA, Manuel Lopes } \\
\text { de [et al.]. Monumenta } \\
\text { Henricina. Coimbra: } 1960 . \\
\text { Vol. 14, doc. 13, pp. 275- } \\
\text { 276. }\end{array}$ \\
\hline Rui Fernandes & $\begin{array}{l}\text { Em } 4 \text { de dezembro de } 1480 \text {, enquanto } \\
\text { escudeiro do Prior do Crato, Rui } \\
\text { Fernandes aparece referido na carta de } \\
\text { quitação a Pero Estaço, recebedor mor } \\
\text { dos dinheiros outorgados pelos povos a } \\
\text { D. Afonso V, tendo recebido de Fernão } \\
\text { Vaz, moço de estrebaria do Prior, } 40 \text { mil } \\
\text { reais, os quais despendeu em nome de } \\
\text { Pero Estaço. Foi também recebedor de } \\
58034 \text { reais dos sacadores de um pedido e } \\
\text { meio e de uma taxa que se pagara em } \\
\text { março, em relação à vila de Avis e a três } \\
\text { aldeias anexas a esta localidade. Recebeu } \\
\text { igualmente } 5870 \text { reais dos privilegiados } \\
\text { de um pedido e meio de seda, mais } 55\end{array}$ & $\begin{array}{l}\text { FREIRE, A. Braamcamp. } \\
\text { Os sessenta milhões } \\
\text { outorgados em } 1478 . \text { In } \\
\text { Archivo } \\
\text { Portuguez. Historico } \\
\text { Lisboa: } 1960, \text { pol. } 425-438 .\end{array}$ \\
\hline
\end{tabular}




\begin{tabular}{|c|c|c|}
\hline & $\begin{array}{l}\text { mil reais de Fernão Pereira, recebedor } \\
\text { dos milhões do almoxarifado de Ponte de } \\
\text { Lima e ainda } 30 \text { mil, relativos a Duarte } \\
\text { Rodrigues, recebedor do almoxarifado da } \\
\text { Guarda, por Gonçalo Anes, moço de } \\
\text { estrebaria do Prior do Crato. }\end{array}$ & \\
\hline Soeiro da Costa & $\begin{array}{l}\text { Era criado do Prior do Crato quando, em } \\
29 \text { de maio de } 1468 \text {, D. Afonso V o } \\
\text { nomeou para o cargo de vedor das obras } \\
\text { do mosteiro e convento de Avis. }\end{array}$ & $\begin{array}{l}\text { A.N.T.T., Chancelaria de } \\
\text { D. Afonso V, Liv. } 28, \text { fl. } \\
\text { 55. }\end{array}$ \\
\hline Vasco Esteves & $\begin{array}{l}\text { Era escudeiro, criado do Prior do Crato e } \\
\text { escrivão da albergaria de Santa Maria da } \\
\text { Vila do Crato e foi privilegiado pelo rei, } \\
\text { em } 9 \text { de dezembro de } 1464 \text {, sendo } \\
\text { autorizado a fazer sinal público nas suas } \\
\text { escrituras. }\end{array}$ & $\begin{array}{l}\text { A.N.T.T., Chancelaria de } \\
\text { D. Afonso V, Liv. 8, fl. } 50 .\end{array}$ \\
\hline Vasco de Évora & $\begin{array}{l}\text { Era criado do Prior do Hospital e, em } 26 \\
\text { de abril de } 1475 \text {, foi nomeado para o } \\
\text { cargo de tabelião das notas, a exercer em } \\
\text { Castelo de Vide. Data do mesmo dia a } \\
\text { apresentação e registro do sinal público } \\
\text { deste beneficiado. }\end{array}$ & $\begin{array}{l}\text { A.N.T.T., Chancelaria de } \\
\text { D. Afonso V, Liv. 30, fl. } \\
\text { 122v. } \\
\text { A.D.P., Cabido, n } 1675 \text {, } \\
\text { fl.18 e } \mathrm{n}^{\circ} 803 \text {, fls. 89-94. }\end{array}$ \\
\hline
\end{tabular}

Fontes (tabela elaborada por nós, com base nas informações obtidas nas obras a seguir):

COSTA, Paula Maria de Carvalo Pinto. A Ordem Militar do Hospital em Portugal: dos finais da Idade Média à Modernidade. Militarium Ordinum Analecta. Vols. 3 e 4. Porto: Fundação Engenheiro António Almeida, 2000, pp. 277-283.

FREIRE, Anselmo Braamcamp. Os sessenta milhões outorgados em 1478. In Archivo Historico Portuguez. Vol. IV. Lisboa: 1960, pp. 425-438.

ALMEIDA, Manuel Lopes de [et al.]. Monumenta Henricina. Coimbra: 1960.

Além de documentos manuscritos diversos citados na própria tabela.

Analisando os privilégios recebidos pela clientela de D. Vasco de Ataíde, percebemos o quanto a relação entre a Coroa e a Ordem do Hospital era essencial para a concretização dos interesses do reino de Portugal. Pelo menos, assim deveriam pensar os monarcas e seus conselheiros. Não fosse assim, não seria fácil explicar a quantidade de favorecimentos régios recebidos pelas pessoas que faziam parte do círculo da casa prioral.

Primeiramente, nos chama a atenção a quantidade de criados e escudeiros do Prior do Crato que chegaram a emprestar dinheiro à Coroa de Portugal, no contexto em que a monarquia se via inserida nos anos 1475-80. Esse apelo à generosidade dos povos tinha o objetivo de custear as despesas reais, que à época da Guerra de Sucessão Castelhana (e da Batalha de Toro), eram excessivamente elevadas.

Segundo Joaquim Veríssimo Serrão (1980, pp. 232-234 apud COSTA, 2000, p.220):

Para tentar resolver o problema da falta de recursos financeiros reuniram-se Cortes em Montemor-o-Novo, de Janeiro a Março de 1477. Nesta 
assembleia, foi pedido aos súbditos um empréstimo. Longe de estar solucionado, este assunto voltou a ser analisado num conselho, convocado pelo infante D. João, e que teve lugar no mosteiro de Santa Maria do Espinheiro, a 20 de Abril de 1478, e nas Cortes de Santarém, em 8 de Setembro. Nesta última reunião dos Estados do reino procurou-se o recebimento dos 60 milhões de reais já concedidos. Segundo a opinião de Veríssimo Serrão, o pedido foi feito em Janeiro de 1477 e a respectiva recolha nos anos 1478 e 1479, negando assim, as propostas de Costa Lobo (LOBO, A. de Sousa e Silva - História da Sociedade em Portugal no Século XV, Lisboa, 1904, pp. 593-602) e de Braamcamp Freire (FREIRE, A. Braamcamp - Os sessenta milhões outorgados em 1478, in "Archivo Historico Portuguez", vol. IV, Lisboa, 1960, pp. 425-438).

Outra característica que nos chama a atenção nesta relação de clientes do Prior do Crato é o fato de que a justiça não funcionava para eles como deveria funcionar para pessoas afastadas dos círculos nobiliárquicos. Há vários casos em que escudeiros libertaram pessoas presas, criminosas, e depois foram perdoados, como foi o caso de Rui de Melo, que acusado de ter tirado, à força, da prisão a mulher de João do Campo, que era considerada culpada na morte de seu marido. Neste caso, Rui de Melo ainda foi nomeado de forma vitalícia para o cargo de coudel da cidade da Guarda.

Noutros casos, como o de Lopo de Cortes, criado de D. Vasco, mesmo matando outro indivíduo, talvez por motivo fútil, ainda foi agraciado com o perdão geral, sendo-lhe perdoada a justiça, sob a condição de ir servir durante três anos em Ceuta, dois dos quais à sua própria custa. Entre ser condenado ou ter que viver em Ceuta (África) durante três anos, é difícil saber qual pena era pior para quem a recebia. Mas se morar em Ceuta era um privilégio régio, é provável que seu privilegiado não recusaria, ainda mais tendo matado outro e estando condenado.

Noutro caso, António Vasques, escudeiro do Prior do Crato, em 1471, recebeu o perdão da justiça régia, por ter agredido e ferido Diogo Serrão. Neste caso, o perdão foi concedido não só a este escudeiro, mas a todos os homiziados da armada e tomada de Arzila e do perdão do lesado. Isso nos remete novamente aos ideais cruzadísticos e ao imaginário dos privilégios que os cruzados recebiam para que tomasse a cruz contra um "infiel, herege ou pagão". Entretanto, na realidade portuguesa o "tomar a cruz" era partir para a conquista da África, combater o Islã ou expandir o cristianismo apostólico romano no Atlântico, em troca dos perdões gerais aos homiziados.

Com relação ao perdão aos homiziados, é preciso explicar que isso se refere aos indivíduos perdoados juridicamente pelos seus crimes, geralmente na condição de viverem num determinado couto, local de fronteira ou por participarem de uma batalha ou guerra. 
Nestes casos apresentados nessa tabela de clientes do Prior do Crato, alguns indivíduos foram homiziados e isento de responderem juridicamente pelas suas condenações, pelo fato de terem participado da tomada de Arzila. Isso demonstra, de fato, quão importante havia sido a conquista daquela praça africana para a monarquia lusitana, como forma de atingir os interesses comerciais portugueses e ainda elevar o rei conquistador, o Africano, ao status de defensor da Cristandade. Ressaltamos que no contexto da Batalha de Toro (1476) também houve um Livro dos Homiziados, o qual tinha a mesma função, atrair condenados das justiças do rei para a guerra e, caso sobrevivessem, estariam livres num prazo que caducaria em três meses, tempo suficiente para tentar obter o perdão do lesado. Tudo isso também ocorria para que o rei pudesse deixar claro que ele perdoa justamente porque pode castigar.

Para concluirmos, vale observar que não eram apenas as relações entre a Coroa e a casa prioral as que são significativas para serem analisadas, mas também as relações entre as pessoas que constituíam essa "casa" e sua relação com o próprio prior, ou seja, o prior e sua clientela. Essa malha de relações sociais que tinha como eixo e como intermediário o prior, favoreceu o que já denominamos de processo de senhorialização das ordens militares, iniciado desde o século XIV. "Esta 'burocracia' era justificada também pela diversidade de lugares que normalmente formavam uma comenda, pelo disfrute, em simultâneo, de outros senhorios por parte dos comendadores e pelas responsabilidades cortesãs, que não raras vezes acumulavam" (COSTA, 2000, p. 244). O conjunto de clérigos, nobres possuidores de cargos régios ou militares e pessoas sem título de nobreza propiciava o desenvolvimento de tais senhorios.

É realmente uma pena que não existam documentos suficientes para que pudesse ser escrita uma história "de baixo para cima", sobre as pessoas comuns que transitavam e faziam parte das dinâmicas de poder nas quais se inseria o Priorado do Crato. O que existe na documentação referente à Ordem do Hospital, que já não é um campo vasto de informações, refere-se a ramos de famílias nobres, outras aristocracias ou, quando muito, dados sobre criados (como os que vimos na tabela acima) que só são mencionados por causa da "importância" da atuação régia sobre eles. 


\section{AS DINÂMICAS DE PODER NO MEDITERRÂNEO}

\subsection{O PRIOR DO CRATO E O CONVENTO CENTRAL DA ORDEM DO HOSPITAL}

Depois da queda de Jerusalém, em 1187, a Ordem do Hospital transferiu sua sede para São João de Acre, de onde foi expulsa, procurando refúgio na Ilha de Chipre em 1291. Em 1309, com a derrota em Chipre, os hospitalários se sediaram na Ilha de Rodes, a qual foi tomada do Império Bizantino (RILEY-SMITH, 1999). Durante mais de duzentos anos Rodes foi a base das atividades defensivas dos hospitalários, em face do avanço islâmico no Mar Mediterrâneo. Nesta ilha, a Ordem criou um principado independente, onde permaneceu quase como uma “Ordem Estado” (BARQUERO GOÑI, 2006, p.20).

Entretanto, nos séculos XIV e XV, o Império Otomano se expandiu pelo Mediterrâneo, pelo Norte da África, chegando inclusive nas terras da Hungria e cercando a ilha de Rodes, onde ficava o Convento Central da Ordem de São João, em duas ocasiões, 1480 e 1522; nessa última ocasião conquistando a Ilha (HOUSLEY, 2004, pp. 148-162). Esse avanço Turco altera os objetivos dos priorados hospitalários em todo o continente europeu, inclusive os do Priorado do Crato, onde se aumenta a necessidade de envio de recursos humanos e materiais ao Convento Central. Vale ressaltar que a Ordem devia obediência ao Papa, o que permitia ao Pontífice usar a milícia como "protetora" da Cristandade e dos territórios cristãos continentais e marítimos, fortemente ameaçados pelo avanço Otomano. Nessa conjuntura, ainda inserem-se as figuras dos soberanos, que em diversas ocasiões foram chamados a participar de confrontos ou enviar recursos ao Grão-Mestre da Ordem, como aconteceu com os monarcas portugueses e espanhóis ${ }^{117}$.

Vale ressaltar que nos primeiros anos do século XV houve significativa paz entre a Ordem do Hospital e seus vizinhos muçulmanos, Mamelucos do Egito, Emirados Turcos da Anatólia e Império Otomano, sendo as primeiras quatro décadas dessa centúria marcadas por acordos de paz. No entanto, a partir dos anos 1440, a Ordem do Hospital sofreu uma insustentável pressão exercida pelos muçulmanos, os quais decidiram atacar a Ilha de Rodes porque o Grão-Mestre se recusava a pagar os tributos exigidos. O sultanato mameluco do

\footnotetext{
${ }^{117}$ Exemplo disso é o Breve Quam pertimescenda, enviado pelo Papa Leão X ao rei D. Manuel I, solicitando que este ordenasse a D. João de Meneses, Prior do Crato, que se apressasse a participar na defesa da Ilha de Rodes, que estava ameaçada de invasão. ANTT, Bulas, m. 36, nº 39.
} 
Egito, sob a liderança de Maomé II, atacou em 1440 e em 1444, e os Turcos otomanos investiram contra a ilha em 1480 e em 1522. Somente em 1523, os hospitalários foram obrigados a abandonar sua sede conventual.

Depois da capitulação de Rodes, em 1522, e após um período em Trípoli, os hospitalários fixaram residência conventual na Ilha de Malta, que em 1530 lhes foi entregue, em forma de feudo da Sicília, pelo imperador Carlos V (PÉREZ PEÑA, 2009). Nos anos seguintes, a Ordem do Hospital passou a ser chamada de Ordem de Malta (BARQUERO GOÑI, 2006, p.21).

Já na Ilha de Malta, a Ordem do Hospital sofreu um ataque do sultão otomano, em 1565, e os hospitalários saíram vencedores (BRADFORD, 2010). A partir de então, a Ordem de Malta serviu como uma espécie de "policía marítima en el mediterráneo para proteger a la navegación occidental de los ataques de la piratería islámica procedente del norte de África" (BARQUERO GOÑI, 2006, p.22) ${ }^{118}$, ou seja, a partir do século XVI, a Ordem de Malta serviu, principalmente, para conter o avanço islâmico no Mar Mediterrâneo ${ }^{119}$.

Depois de 1480, a Ordem do Hospital torna-se bastante prestigiada entre os cristãos, o que influencia diretamente as dinâmicas internas das Línguas e Priorados da instituição. A vitória hospitalária no cerco de Rodes, em 1480, elevou o status dos cavaleiros dessa milícia; ou seja, manter a presença hospitalária tornou-se um fim em si mesmo, pelo fato de terem resistido ao poderoso cerco Turco (HOUSLEY, 2004, p. 162).

Sobre a presença dos hospitalários nas ilhas mediterrânicas, Martim de Albuquerque escreveu o seguinte (1998, p. 16):

Em 1310 fixam-se em Rodes, ilha conquistada definitivamente pelo Mestre Frei Foulques de Villaret. A sua posição insular e a sua marinha passam a dominar a navegação do Mediterrâneo Oriental, servindo assim a Ordem como a grande base naval do Ocidente. A permanência dos cavaleiros em Chipre e Rodes vincou para sempre a feição monumental da ilha - o Palácio dos Grão-Mestres, os hospitais (o grande hospital é hoje o Museu Arqueológico), as ruas medievais, a começar pela Rua dos Cavaleiros, as muralhas, os palácios das diversas "nações", tudo isto atesta o apogeu dos Hospitalários em Rodes. Mas também a vocação marítima da Ordem, que se perpetuará em Malta. Os cavaleiros de Rodes e de Malta estavam posicionados, naturalmente, em condições excelentes para participarem na grande aventura quinhentista e seiscentista dos mares. Desde logo, o papel marítimo da Ordem no Mediterrâneo articula-se com a acção dos Descobrimentos. Ceuta (1415), cuja conquista marca o início da diáspora

\footnotetext{
118 Segundo este autor, a Ordem do Hospital também sentiu o impacto da Reforma Protestante e sofreu muitas perdas patrimoniais na Europa continental, onde parte dos bens hospitalários foi secularizada.

119 Não era nosso objetivo analisar o panorama mediterrânico da Ordem do Hospital no século XVI e nos seguintes. Apenas mencionamos brevemente a fim de contextualizar.
} 
europeia pelo mundo, como observou Costa Lobo, desempenha durante séculos para o Mediterráneo Ocidental o mesmo papel que os cavaleiros de São João desempenhavam em Rodes e em Malta.

Imagem 5 - O Mediterrâneo Oriental em 1450

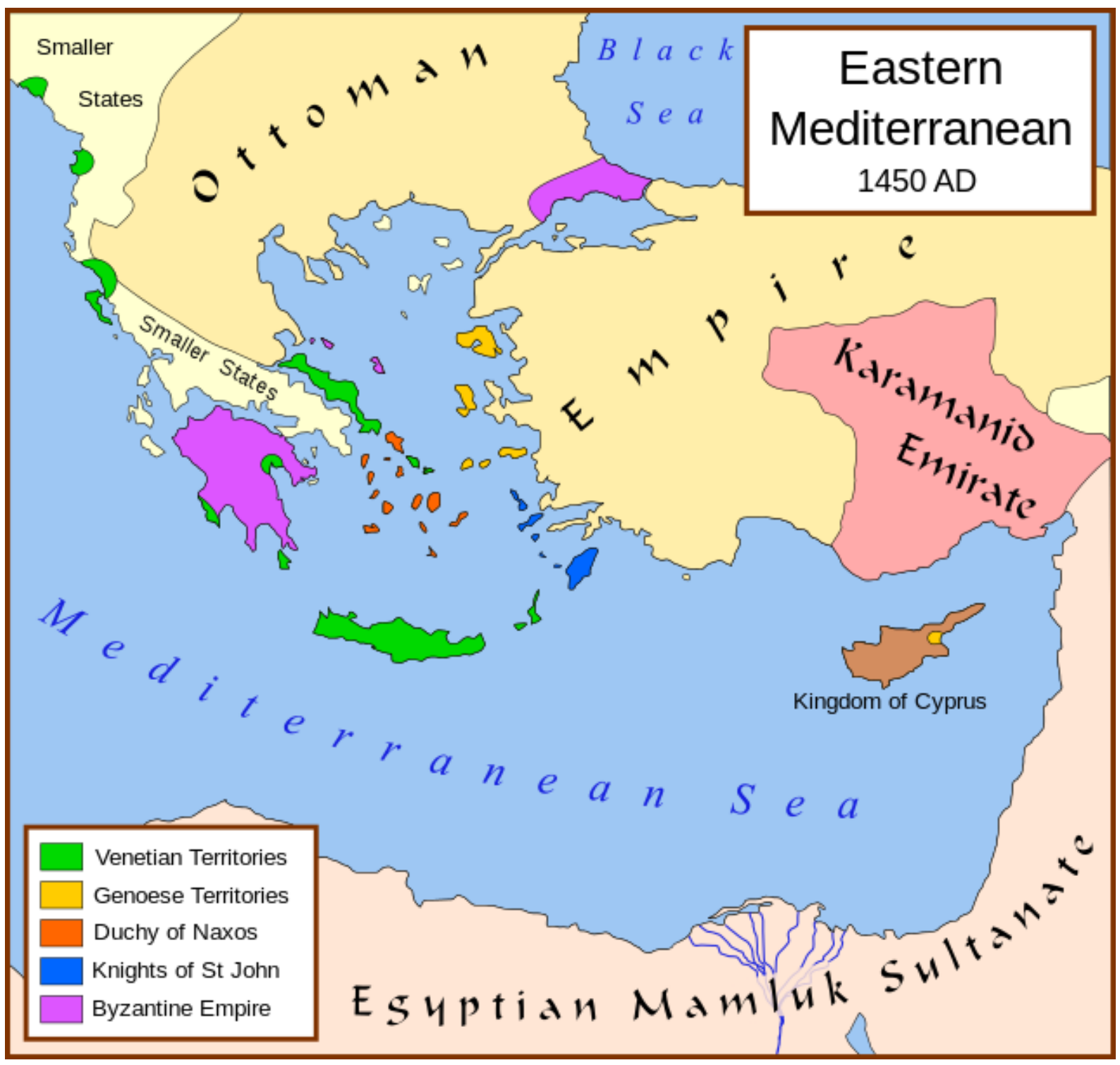

Fonte: MAPMASTER. A political map of the eastern Mediterranean Sea, in 1450. Disponível em: https://en.wikipedia.org/wiki/Knights_Hospitaller\#/media/File:Eastern_Mediterranean_1450.svg. Consultado em: 20 de março de 2015.

Sobre a relação da ilha de Rodes com as navegações e o expansionismo português, Martim de Albuquerque ainda disse o seguinte (1998, p. 16):

Rodes foi a base de partida da grande aventura de Afonso de Paiva e Pêro da Covilhã. É de Rodes, com efeito, que estes dois portugueses saem da Europa para a sua grande peregrinação com vista a atingirem a Índia por terra. Governava então a Ordem o Grão-Mestre Pierre d'Aubusson, com quem os 
reis de Portugal e os Portugueses mantiveram as melhores relações, e sob o qual foram mandados servir numerosos cavaleiros. E ao tempo da aventura de Afonso de Paiva e Pêro da Covilhã estacionavam na ilha, entre outros cavaleiros, os portugueses Frei Gonçalo e Frei Fernando. Em Rodes fizeram os viajantes os seus aprovisionamentos e embarcaram para Alexandria, de onde começaram a sua grande peregrinação terrestre e oriental, que tão importante seria na descoberta do caminho marítimo para a Índia.

Fazendo uma análise dos acontecimentos que envolveram a Ordem do Hospital no contexto militar mediterrânico no século XV, podemos listar o seguinte: em 1440 aconteceu o Primeiro Cerco de Rodes pelos Mamelucos; em 1444, o Segundo Cerco de Rodes pelos Mamelucos; em 1453, queda de Constantinopla e fim do Império Bizantino; 1480, Terceiro Cerco de Rodes pelos Otomanos (também chamado de Primeiro Grande Cerco de Rodes), ocasião em que o Grão-Mestre frei Pierre d'Aubusson sai tão vitorioso que é feito Cardeal, pelo Papa Eugênio IV.

Sobre o Cerco de Rodes de 1480, Conde de Campo Bello escreveu (1931, pp. 66-67):

Por espaço de três meses lutou-se incessante e tenazmente de ambos os lados. Tais foram porém os prodígios praticados pelos Hospitalários, que por fim os otomanos tiveram de bater em retirada. Viu-se então claramente como tinha sido perspicaz e previdente a tática dos últimos Grãos Mestres, munido a ilha de fortificações capazes de desafiar quaisquer esforços de invasores. Ficaram particularmente memoráveis os ataques à Torre de S. Nicolau, cuja guarnição resistiu com uma heroicidade raras vezes igualada. Também se cobriram de louros no cerco os Cavaleiros Portuguêses que se achavam em Rodes, principalmente Frei Luís Petrosa, Frei Rodrigo Mendes, Frei Álvaro de Godiñe, Frei Fernando Gonçalves, Frei D. Henrique de Castro, mais tarde Prior, e Frei Pedro Laurentia. Chefiava-os D. Diogo Fernandes de Almeida, filho de D. Lopo de Almeida, $1^{\circ}$ Conde de Abrantes, Monteiro-Mór de D. João II a quem serviu em África, do conselho do mesmo Rei, e Alcaide-Mór de Torres Novas.

No excerto acima, Campo Bello nos traz uma informação importante, a presença de D. Diogo Fernandes de Almeida no cerco, nobre de família bastante influente em Portugal, que viria neste mesmo ano de 1480 ser eleito ao cargo de Prior do Crato, cargo que só ocuparia de forma contínua após a morte de D. Vasco de Ataíde, em 1492. Diogo Fernandes de Almeida já havia participado de inúmeras batalhas ao lado do rei de Portugal D. Afonso V no Norte da 
África e também da Batalha de Toro (1476) ${ }^{120}$, no contexto da Guerra de Sucessão Castelhana, como viremos a discorrer no próximo tópico deste capítulo ${ }^{121}$.

Sendo Diogo de Almeida quem chefiou os hospitalários de Portugal na ilha de Rodes durante os meses do cerco, em 1480, é provável que tenha acontecido uma das três situações: I) O Prior D. Vasco de Ataíde não estar presente por simplesmente não ter ido à ilha nesta ocasião, sem nenhum motivo a se considerar; II) O Prior D. Vasco de Ataíde ter se deixado liderar por outro cavaleiro mais experiente, no caso Diogo Fernandes de Almeida, havendo assim quebra de hierarquia; III) Vasco de Ataíde ter ido à ilha e por lá ter se ferido ou adoecido a ponto de não poder lutar naquele momento e talvez até nunca mais.

A primeira situação é bem provável, tendo em vista a ausência de menção ao seu nome pela documentação, se bem que alguns documentos dizem que D. Vasco de Ataíde foi a Rodes diversas vezes (RIBEIRO, 1800, pp. 75-96). A segunda situação é relativamente aceitável, mas não houve quebra de hierarquia, tendo em vista que a documentação informa que D. Diogo de Almeida tinha sido eleito Prior do Crato antes de sair de Portugal em direção à Rodes. A terceira hipótese poderia ser tida como admissível, tendo em vista que Diogo Fernandes de Almeida até mesmo chegou a ser eleito Prior do Crato, mas não porque Vasco de Ataíde estivesse ferido ou doente ao ponto de ninguém mais achar que ele sobreviveria (a documentação é omissa quanto a isso), mas sim por ele estar demasiado velho, teoria na qual acreditamos.

Segundo Paula Pinto Costa (2000, p. 277):

Para além de todas as actividades que desenvolveu no reino e Priorado de Portugal, Fr. Vasco de Ataíde deslocou-se várias vezes a Rodes, respondendo às exigências que a instituição lhe colocava, sendo substituído durante a sua ausência pelo comendador de Belver, Álvaro Pires de Avelar, enquanto seu lugar-tenente.

A mesma coisa escreveu Conde de Campo Bello (1931, pp. 81-82):

Este Prior teve de se ausentar várias vezes do país, não só para tomar parte nas guerras de África e de Espanha, mas também se achou em Rodes por diferentes ocasiões, e então substituía-o o Comendador de Belver Frei Alvaro Pires, com o título de Lugar-Tenente.

\footnotetext{
${ }^{120}$ Chronica de El Rei D. João II, de Rui de Pina (1950, cap. 27) e Crónica de D. João II e Miscelânea, de Garcia de Resende (1973, caps. 67 e 81).

${ }^{121}$ Autores que se referem a D. Diogo Fernandes de Almeida como freire do Hospital, suas façanhas e como Prior do Crato: ALBUQUERQUE, 1992, pp. 161-164; FREIRE, 1996, vol II, p. 361, e vol. III, p. 142; e RIBEIRO, 1800, p.80.
} 
Não sabemos a data de nascimento de D. Vasco de Ataíde, mas sabe-se que seu pai, D. Álvaro Gonçalves de Ataíde, Primeiro Conde de Atouguia, nasceu em 1390 e faleceu em 1452. Por isso, consideramos que, em 1480, D. Vasco de Ataíde já seria um idoso. Provavelmente, esse tenha sido o motivo da suposta ausência dele na defesa de Rodes, durante o cerco otomano.

Apesar disso, D. Vasco de Ataíde ficou vivo até 1492 e só então Diogo de Almeida assumiu definitivamente o cargo de Prior do Crato, cargo que exerceu até o dia de sua morte, em 13 de maio de 1508 (RIBEIRO, 1800, p. 92).

Ainda sobre a relação do Prior do Crato com o Mestre e Convento Central da Ordem e suas idas à Rodes, vale ressaltar que antes do evento destacado acima (cerco de Rodes de 1480), D. Vasco de Ataíde tinha participado de diversos capítulos gerais da Ordem do Hospital. Podemos citar como exemplo, o Capítulo Geral de 1462, em Rodes, ocasião em que se discutiu e se concretizou a divisão da língua comum que existia para toda a Península Ibérica em duas outras línguas, a "Língua de Castela e Portugal" e a "Língua de Aragão, Catalunha e Navarra", o que provocou disputas em Castela e Portugal até que os freires dos priorados chegaram a um acordo em 1467, segundo o qual dividiram em partes iguais os cargos correspondentes da nova Língua (BARQUERO GOÑI, 2003, p. 135). Entretanto, para se chegar nesse acordo, foi preciso, em 1466, que o Grão-Mestre convocasse todos os priores, comedadores e freires a um outro Capítulo Geral, desta vez em Roma, do qual D. Vasco de Ataíde também participou (RIBEIRO, 1800, p. 68).

Neste Capítulo Geral de 1462, D. Vasco de Ataíde, por tão boas relações com a monarquia portuguesa e com o Mestre da Ordem do Hospital, fora nomeado Embaixador do Convento Central e Lugar-tenente do Grão-Mestre para que pudesse exercer funções de "fazer pagar as imposições, e Annatas, visitar, correger, e reformar o que lhes parecesse convincente, e revogando para esse fim os Privilegios concedidos a quaisquer Priorados, ou Religiosos”, preservendo somente os privilégios que parecessem úteis à Ordem. Além disso, essa nomeação ainda era acompanhada de uma patente, que fora enviada ao Pontífice, imperador, reis, dizendo a respeito das investidas dos Turcos e os "grandes perigos, e guerras, que ameaçavam a Religião", suplicando a esses soberanos que favorecessem e amparassem aos hospitalários em seus objetivos (RIBEIRO, 1800, p. 67).

Antes disso, segundo José Anastásio de Figueiredo Ribeiro (1800, p. 65), D. Vasco de Ataíde só não particou das primeiras grandes expedições de D. Afonso V na África, em 1458 , porque "podemos bem suppôr que elle ficaria apromptando-se para hir com alguns Comendadores servir a sua Ordem em Rhodes, onde estava tendo assento, ou cabeça della". 
Voltando ao assunto da participação dos freires hospitalários no cerco de Rodes, em 1480, observe o que escreveu José Anastásio de Figueiredo Ribeiro na sua obra publicada em 1800 (pp. 81-82) ${ }^{122}$ :

Nem mesmo quando o Chronista Mór Ruy de Pina no Cap. CCVIII. da sua Chronica tantas vezes citada, escrevendo do mez de Novembro de 1480, certifica bem notavelmente, que neste tempo fôra a Cidade, e Ilha de Rhodes cercada de Turcos (600) (?), em 160 vellas, ainda ás ordens de Mahomet II., e posta em grande aperto, sendo Grão-Mestre Dom frey Pedro d'Abaabusam, a cujo socorro foy destes Reynos Dom Diogo Fernandes d' Almeida que trazia o Abito da dita Ordem, \& era eleito pera ser como foy Prior do Crato, \& foy bem armado \& aparelhado, \& no caminho \& em Rodes gaanhou muyta honra, sendo ferido, pelejando com gallees, \& fazendo ricas presas como homem de nobre sangue, a que em todas suas cousas d'antes \& despois nunca falleceo deferiçam, bondades, \& grande esforço de coração. Em cujo grande cêrco já publicou Funes na Parte I. da sua Chron. Liv. IV. Cap. 17. p. 411 (depois das ultimas Cartas de Citação, dirigidas aos Priorados do Ocidente, com daa de 20 de Julho de 1479, pelo theor transcripto no citado Liv. IV. Cap. 13, p 384. e segg.), que se acharam Comendadores, e Cavalleiros do Priorado de Portugal Fr. Luiz Petrosa, Fr. D. Diogo de Almeida, Fr. Rodrigo Mendes, Fr. Alvaro de Godiñe, Fr. Fernando Consalvo, ou Gonçalves, e Fr. Pedro Laurentia. Por quanto não consta mais, que o Prior D. Vasco d' Athaîde continuasse a fazer, senão entre nós, a fiorentissima, e muito fértil Epoca para a Historia da sua Ordem, em que ajuntou os maiores merecimentos, e autoridade, ainda por quasi todo o Reinado do Sr. Rei D. João II, seu afilhado. como se prova, não só por muitas Graças, e Mercês, que este lhe fez como particular, sem haverem de passar á dita Ordem; mas primeiramente por ser a elle, que ainda foi concedida a Carta de Confirmação Geral em 12 de Outubro do anno de 1485 , da qual se falou no $\S 44$. da minha Parte I. Ao mesmo tempo que, o sobredito D. Diogo Fernandes de Almeida tinha já voltado para o Reino, e nelle estava sendo só do Conselho, e Monteiro Mór daquelle Sr. Rei, quando por Carta dada em Santarèm a 16 de Janeiro de 1486 (a f. 160 do Liv. VIII. da sua Chancellaria) lhe fez Mercê o mesmo Principe de o fazer Alcaide mór de Torres Novas, como o tinha sido por Carta d'ElRei seu Pay.

Quantos aos feitos de D. Diogo Fernandes de Almeida quando já atuava como Prior, os autores não economizam palavras. Segundo BELLO (1931, p 68) ${ }^{123}$, algum tempo após a resistência hospitalária ao cerco Otomano:

\footnotetext{
${ }^{122}$ Vale a pena informar que estas análises que apresentamos sobre a obra de José Anastácio de Figueiredo Ribeiro, de 1800, têm como fontes principais utilizadas por este autor a Chronica de D. Afonso V, de Rui de Pina, e a Chronica da Ordem de Malta do frei D. João Agostinho de Funes, chegando essas análises a serem, às vezes, meramente plágios dessas crônicas. A crônica de Rui de Pina foi bastante analisada por nós, já a de Funes não nos foi possível encontrar.

${ }^{123}$ Sobre a capitulação de Rodes, definida pela derrota hospitalária no Segundo Grande Cerco de Rodes de 1522, o Conde de Campo Bello (1931, pp. 71-72) diz o seguinte: "Era grande então o prestígio de que gozavam os Cavaleiros de Rodes. A ilha admiravelmente defendida por muralhas e baluartes - que em grande parte resistiram até hoje ao vandalismo dos homens e à intempérie dos séculos - desafiava os inimigos mais audazes; a sua frota sulcava em tôdas as direcções os mares circunvizinhos, dando caça, sem tréguas, a piratas e muçulmanos; a sua situação internacional era magnífica em relação às potências europeias, e aos maometanos
} 
Emerico d'Amboise, irmão do célebre Cardeal francês Arcebispo de Rouen, foi o Grão Mestre seguinte. Distinguiram-se nesse tempo as armadas de Rodes em diferentes combates navais. Num dêles notabilisou-se mais uma vez por feitos valorosos o Prior de Portugal, Frei D. Diogo Fernandes de Almeida, que com quatro galés de seu comando destroçou dezasseis navios turcos; igualmente se salientou então um outro português Frei André do Amaral, "general das galés da Religião do Hospital".

No século XV, o ambiente no Mar Mediterrâneo podia ser resumido em uma palavra: “guerra". O Mediterrâneo era o principal palco das lutas entre cristãos e muçulmanos. É preciso realçar a memória das lutas infindáveis e das batalhas sangrentas que salvaram o Ocidente Cristão, em que a Ordem do Hospital ou seus cavaleiros intervieram. Recordemos os feitos do Grão-Mestre Pierre d'Aubusson (1476-1503), que chegou a receber a denominação de "Escudo da Cristandade" (bouclier de la chrétienté), por ter resistido, em 1480, com sucesso em Rodes ao assalto de cem mil Turcos, vitória que foi celebrada como uma das mais significativas do século XV (ALBUQUERQUE, 1998, p. 18).

Em 1481, o mesmo Grão-Mestre assinou um acordo de paz com os Turcos, que durou até o ano seguinte. O Grão-Mestre Pierre d'Aubusson tinha chamado para a cruzada os reis de Nápoles e da Hungria, que não atenderam ao seu chamado. Por isso, o Convento Central decidiu negociar a paz com os Turcos. Com esse acordo, a Ordem do Hospital tinha que devolver os fugitivos otomanos, caso fossem muçulmanos ou cristãos, mas no último caso os muçulmanos teriam que pagar em dinheiro para que a devolução se concretizasse. $O$ Convento Central começava a perceber que devido à proximidade geográfica e ao poderio cada vez maior dos Turcos, era melhor planejar acordos do que estratégias de guerra (HOUSLEY, 2004, pp. 150-160).

Sobre a negativa dos reis de Nápoles e da Hungria em iniciar uma cruzada ao lado da Ordem do Hospital, o cronista Guillaume Caoursin, teceu suas críticas (CAOURSIN, $1870)^{124}$ :

inspirava um perpétuo terror o valor sem igual da Milícia Jerusalemitana. Rodes era ainda um rico empório. Por fim, os Hospitalários, muito dizimados; esgotados os víveres e sem armas; arruinadas em alguns pontos as fortificações pela acção destrutiva da artilharia pesada otomana; e tendo esperado em vão qualquer socôrro do Ocidente - a que tinham incontestável direito, eles que sempre coadjuvavam eficazmente os estados cristãos não tiveram outro remédio senão capitular no mês de Dezembro de 1522. Não foi esta uma rendição humilhante ou que lhes diminuísse o prestígio, porque perante a desproporção esmagadora do número, não havia outro caminho a seguir. E Solimano tanto admirou a atitude dos Cavaleiros de São João, que lhes consentiu ao retirarem-se de Rodes levar consigo as bandeiras, os canhões e as outras armas que possuíam, e embarcaram nas suas próprias galés. Aos habitantes da ilha foi concedido poderem acompanhar os Hospitalários, e aqueles que preferissem permanecer em Rodes ficaram isentos de todo e qualquer imposto durante cinco anos".

124 Bibliothèque Nationale de France. Opera Guillelmi Caoursin, Rhodiorum vicecancellarii: Obsidionis Rhodiae Urbis Descriptio. Res. K-89. Guillaume Coursin esteve presente como Vice-Chanceler da Ordem no 
Failing to open eyes that are clouded by the mists of passions, the Christians reject the opportunity offered to them, and each is preoccupied with his own affairs. For sure, the blood of Christ is colder in the spirits of Christians than the Sarmatic Sea; those who should be boilling are frozen by a more than glacial cold.

Caoursin se referindo ao tratado de paz entre o Convento Central da Ordem do Hospital e o Império Otomano, escreveu o seguinte (CAOURSIN, 1870) ${ }^{125}$ :

Peace is known to be a gift oa such a celebrated and excellent nature that it is easy to persuade the spirit to embrace it. But while everyone welcomes it with open arms, the yearning is strongest amongst the multitude who earn their livind in the cultivation of the fields. For generous soldiers, accustomed to arms, pursue glory in military action... But circumstances often demand that we take pity on the troubles of the peasants whose sweat enables food to reach the princes and soldiers.

Este trecho de Caoursin nos faz refletir sobre o imaginário da cruzada, tão inserido nas mentalidades dos que viveram os séculos XV e XVI. Para as pessoas daquela época, os cristãos tinham um inimigo em comum cada vez mais poderoso, o Islamismo. Mesmo diante das guerras entre reinos europeus e entre senhores feudais, nada era mais significativo, em termos psicológicos, do que o pavor que o "infiel" causava, principalmente naqueles que estavam diretamente ligados ao Movimento de Cruzada, a citar, cavaleiros, navegadores, soberanos e até mesmo o próprio Papa, que nestes tempos acompanhava a ameaça Turca chegar cada vez mais perto de si (e de suas possessões e interesses na Península Itálica). Os comerciantes sequer podiam navegar tranquilamente no Mar Mediterrâneo, pois havia o constante e real perigo de saques, o corso. Isso fez, inclusive, Portugal procurar novas rotas para comercializar com as Índias, o que talvez tenha resultado, indiretamente, em todas as conquistas na costa da África.

O corso, entretanto, era algo que também causava temor nos muçulmanos. A própria frota hospitalária de Rodes, e seus protegidos, atacavam embarcações muçulmanas e suas mercadorias, o que também tornou a Ordem bastante impopular no Oriente Médio. O Hospital concedia licenças de travessia no mediterrâneo e atuava com ações de pirataria contra navios que forneciam suprimentos ao Império Turco e aos muçulmanos em geral. Principalmente depois da instalação em Malta, a principal atividade da Ordem de São João no Mediterrâneo

Cerco de Rodes de 1480 e, algum tempo depois, publicou sua crônica a respeito da batalha e das redes de poder que envolviam o Convento Central da Ordem do Hospital.

${ }^{125}$ Idem nota de rodapé anterior. 
foi o corso. Com isso, a Ordem garantia a "segurança cristã dos mares" (HOUSLEY, 2004, pp. 149-162).

\section{Imagem 6 - Grão-Mestre Pierre d'Aubusson em Rodes.}

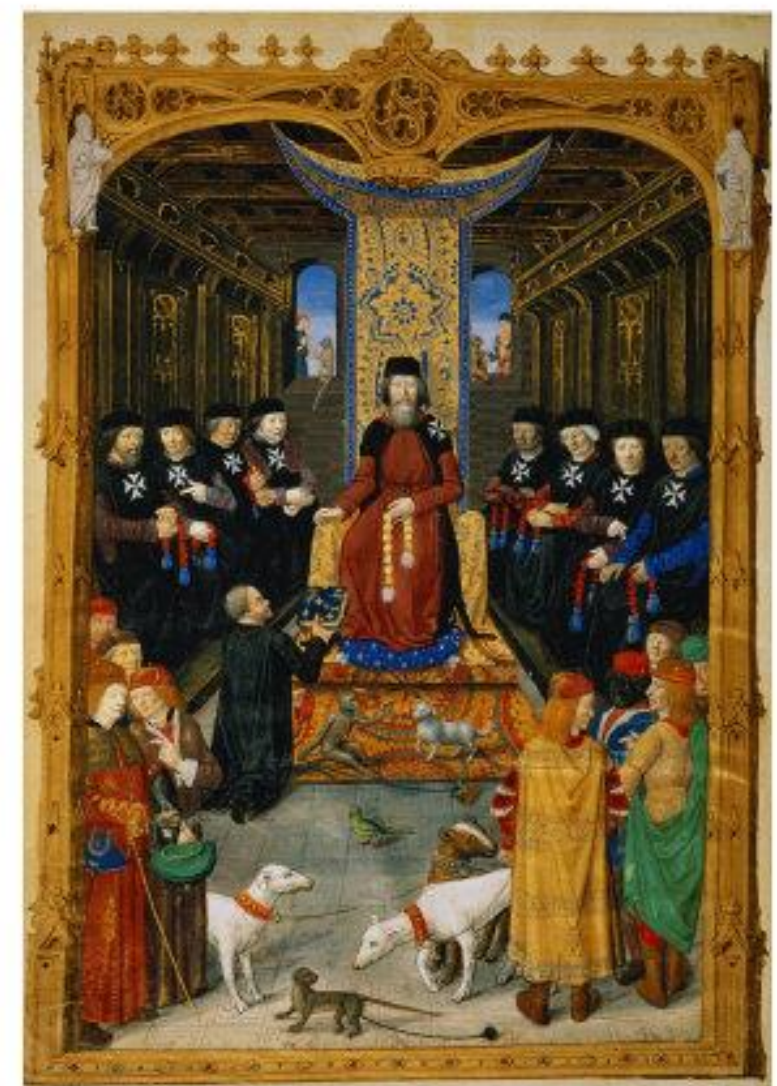

Fonte: Bibliothèque Nationale de France, ms. Lat 6067, fl. 3v. Guillaume Caoursin presenteando ao Grão-Mestre Pierre d'Aubusson com seu livro História do Cerco de Rodes, em 1483.

Sobre o cronista Guillaume Caoursin, testemunha ocular do cerco de 1480 e ViceChanceler da Ordem do Hospital, Helen Nicholson escreveu o seguinte (2011, p. 62):

The Hospital publicised in Europe what was depicted as miraculous victory. Pope Sixtus IV sent his congratulations and authorised the brothers to sell indulgences in Europe to those who contributed towards the rebuilding of their fortifications. The Latin account of the siege by Guillaume Caoursin, vice chancellor of the Order, was printed and between 1481 and 1489 editions were publised throughout western Europe, as well as translations into English (by John Kay) and French. This raised the Order's prestige in Europe and encouraged donations; but nevertheless it was left very vunerable to another attack. The defensibility of the town was further undermined by a succession of earthquakes in 1481. If Mehmed II had had attacked in 1481 he would probably have captured Rhodes, but his death followed by the war between his sons Beyezid II and Jem, prevented immediate assault. Instead, Bayezid made a truce with the Hospital in late 
1481, while Jem turned to the Hospitallers for assistance. He arrived in Rhodes in late July 1482 and made a perpetual treaty of Peace with Grand Master Aubusson. He then sailed to the West to seek assistance for a war against his brother. The Hospital was authorised to negotiate on his behalf with Bayezid, and a Peace treaty was made between the sultan and the Order in December 1482. According to this, the Hospital would keep Jem in the West and prevent western European sovereigns from using him against Bayezid. To demonstrated his debt to the Order in this matter, Bayezid promised an annual payment for Jem's expenses, and sent the Hospital the relic of the right hand of St John the Baptist, patrono of the Order. The hand, enclosed in a reliquary, remained one of the Order's most precious relics ${ }^{126}$.

De fato, a História do Cerco de Rodes, ${ }^{127}$ de Guillaume Caoursin, impressa entre 1481 e 1489, foi o texto que mais divulgou a vitória hospitalária sobre os Turcos, contando detalhes sobre os meses de cerco. Essa obra fez com que os cristãos na Europa admirassem imensamente a Ordem do Hospital, aumentando então seu prestígio e propiciando, desta forma, significativas contribuições à instituição. E, em tempos de guerra, receber doações era o que a Ordem de São João mais apreciava.

Apesar da tentativa de se manter a paz, a Ordem do Hospital precisou declarar guerra novamente contra o Islã. De 1499 a 1503, os venezianos combateram os Otomanos em uma guerra na qual o Papa colocou os hospitalários como líderes da liga cristã. Somente em 1503, Veneza e Hungria tratam de fazer as pazes com os Turcos. Apesar disso, os rancores tornavam-se imperdoáveis. Anos depois, o Sultão Turco Selim I conquista o Egito, a Síria e a Palestina, deixando o Convento Central da Ordem rodeado. Em 1521, os Turcos atacam Belgrado e, em 1529, atacam Viena. Rodes se tornara a posição cristã mais avançada no Oriente. Em 1522, após vários pedidos de ajuda feitos pelos papas aos reis europeus, que não acreditavam que Rodes cairia e que por isso não enviaram ajuda militar suficiente, Rodes se rende, após um conflito que durou quase seis meses (HOUSLEY, 2004, pp. 149-162).

Sobre a paz com os Turcos Otomanos, Normam Housley escreveu o seguinte (HOUSLEY, 2004, pp. 161-162):

\footnotetext{
${ }^{126}$ Esta citação ainda se refere ao incidente diplomático provocado por Djem, irmão do Sultão Turco. Depois de ser derrotado na disputa pelo trono, se refugiou em Rodes em 1482. O Grão-Mestre do Hospital obteve, assim, um valioso refém para negociar com o Sultão Bayaceto II. Djem foi enviado às possessões da Ordem do Hospital na França e obteve do Sultão Turco o pagamento de uma elevada quantidade anual, além da interrupção dos ataques turcos ao Hospital e aos demais ocidentais no Mediterrâneo, em troca de que se mantivesse Djem neutralizado. Posteriormente, em 1489, os hospitalários tiveram que entregar Djem ao Papa. Djem morreu em Nápoles em 1495 (BARQUERO GOÑI, 2003, p. 224). Nota nossa.

127 Bibliothèque Nationale de France. Opera Guillelmi Caoursin, Rhodiorum vicecancellarii: Obsidionis Rhodiae Urbis Descriptio. Res. K-89.
} 
For Anthony Luttrell ${ }^{128}$, the installation of the Knights at Rhodes at the start of the fourteenth century should cause us to think that they had accepted that the reconquest of Jerusalem was no longer an objective, and that they had realized that the crusade was going to become a defensive war against the Ottomans. The Order could not abandon the crusade, which was its raison d'être, but it could 'in its own ways divert, or even pervert, it'. As we have seen, subsequent events seem to support this conclusion. It seems certain that after the failure of the Ottoman siege of 1480, nobody in Europe seriously considered challenging the Hospitaller presence at Rhodes. The glory that the Order had derived from the victory was buttressed by the personal prestige of Pierre d'Aubusson, whose magistracy lasted for more than half of the period covered by this essay, from 1476 to 1503 . The Venetians could denounce him as a 'friend of the Turk', and not without apparent reason: but it remains the case that he had fashioned Rhodes into a bastion of Christendom in the East, the only one capable of standing fast against the Turk and of dictating terms to him. After 1480, maintaining the Hospitaller presence constituted an end in itself, not only for material reasons that do not concern us here, but also for moral reasons.

Em 1481, outra infelicidade assolou o Convento Central da Ordem, um terremoto que abalou significativamente as estruturas das construções de Rodes. Em 1521 vem a Reforma Protestante, o que gera perda de patrimônio hospitalário na Europa e diminuição de envio de recursos à ilha de Rodes. A partir de 1492, com a chegada dos europeus à América, a luta contra o Islã deixa de ser a principal preocupação dos monarcas ibéricos, o que dividia a atenção destes com relação aos auxílios prestados à Ordem do Hospital.

Toda essa sequência de conflitos necessitava de recursos, cada vez mais recursos, o que em determinados momentos se tornava um imenso problema para o Convento Central da Ordem. Sustentar a guerra contra o Islã era algo demasiado caro, o que requeria o envio de tropas, dinheiro, metais, armas, pólvora, animais diversos e outros mantimentos tanto por parte dos priorados espalhados nos reinos europeus quanto pelos próprios monarcas. E para ainda complicar mais a situação, pouco auxílio advinha dos mosteiros ocidentais, por causa das guerras se travavam entre Gênova e Aragão, e entre Inglaterra e França, o que reduzia demasiadamente as receitas das respectivas Línguas e Priorados. Além disso, na Boêmia, grupos de Hussitas saqueavam localidades e também provocavam diminuição dos rendimentos dos hospitalários (BELLO, 1931, p. 63).

Vale ressaltar que também era muito comum o envio de recursos humanos ao Convento Central, principalmente de freires (cavaleiros, serventes e capelães) com o objetivo de contribuir com a defesa da ilha de Rodes e de participar nas expedições da Ordem pelo

\footnotetext{
${ }^{128}$ Para maiores informações: LUTTRELL, Anthony. The Hospitallers of Rhodes and ther Mediterranean World. Edição Reimpressa. Hampshire: Ashgate Publishing, 2002. LUTTRELL, Anthony. The Making of Christian Malta: from the Early Middle Ages to 1530. Hampshire: Ashgate Publishing, 2002. Nota nossa.
} 
Mediterrâneo Oriental. Contudo, os membros da Ordem que viviam no Ocidente somente eram chamados pelo Grão-Mestre para defender Rodes em momentos de grande perigo. Convocados, se não comparecessem corriam o risco de perderem seus cargos e até mesmo o hábito da Ordem do Hospital.

Imagem 7 - Extensão do Império Otomano (1481-1683).

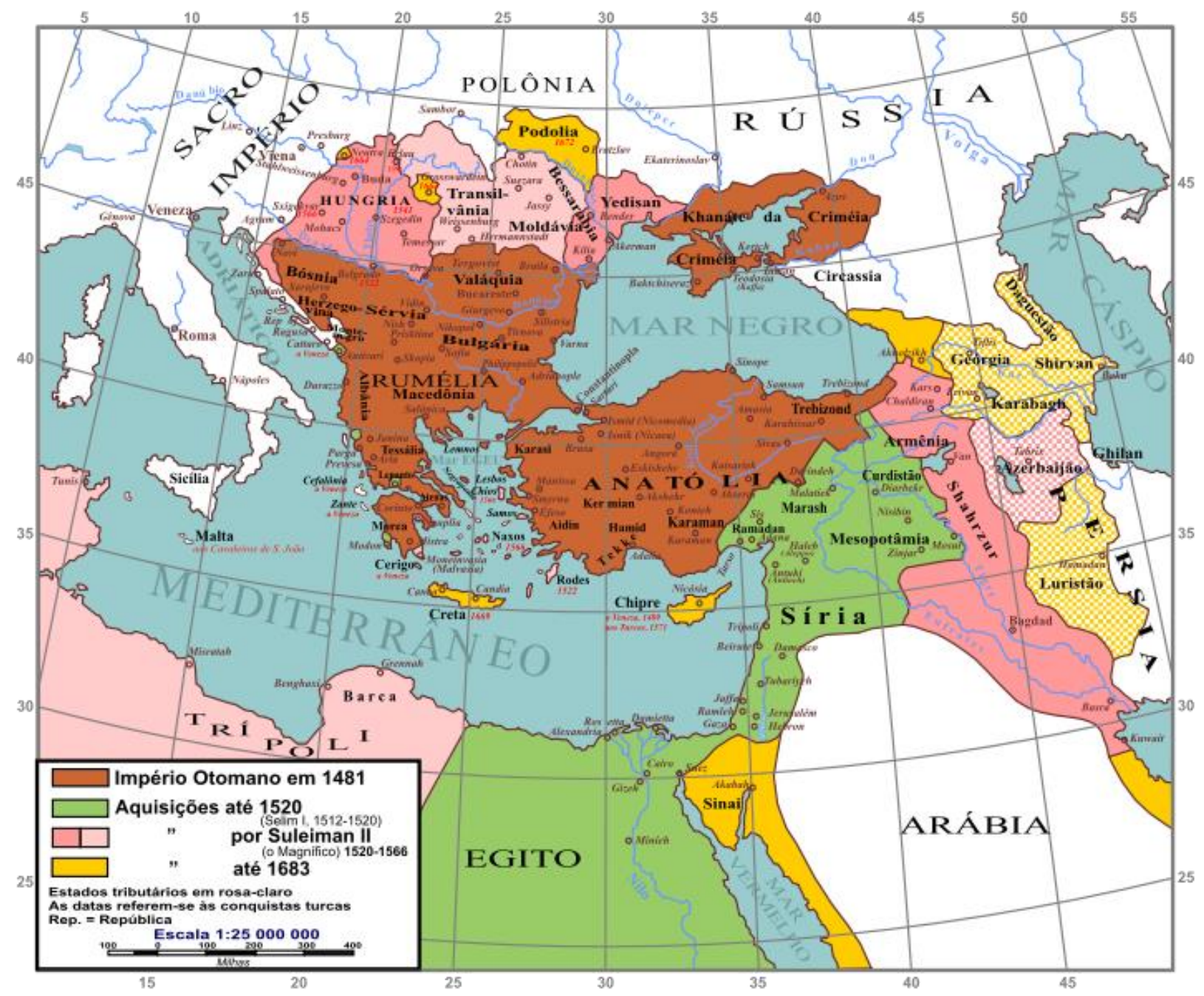

Fonte: KOHENE, André. Extensão do Império Otomano, entre 1481-1683. Disponível em: https://pt.wikipedia.org/wiki/Imp\%C3\%A9rio_Otomano\#/media/File:Otomano_europa_pt.svg. Consultado em: 20 de março de 2015.

Em princípio, a principal finalidade das possessões da Ordem do Hospital na Europa Ocidental era contribuir com a manutenção do Convento Central no Mediterrâneo. Durante os séculos XII e XIII todas as comendas desta instituição deviam pagar anualmente um terço de 
suas rendas ao Convento Central. Este tributo era chamado de "responsão"129. Durante esses dois primeiros séculos, já havia envio de recursos dos priorados hospitalários peninsulares ao Grão-Mestre e Convento. "Sin embargo, por desgracia se conserva muy poca información sobre el tema. Apenas sí podemos certificar la existencia de las 'responsiones' en la Península durante esta época" (BARQUERO GOÑI, 2003, p. 175).

Nos séculos XIV e XV, após a fixação da Ordem do Hospital em Rodes desde 1310, os envios dos priorados ocidentais são fundamentais para a sustentação dos hospitalários na ilha. Nestes séculos, os hospitalários ibéricos enviaram consideráveis quantias de dinheiro à Rodes, em forma tanto de responsões (tributos anuais) quanto de outros tipos de tributos ${ }^{130}$.

De acordo com Carlos Barquero Goñi (2003, p. 176):

La documentación nos permite verificar que estas transferencias monetarias desde la Península se verificaban realmente por lo menos en parte. Las cuentas sanjuanistas de los años 1373-4 y 1374-5 constaban notables desembolsos por parte de la castellanía de Amposta (2.417 y 2.243 florines, respectivamente) y de los prioratos de Navarra (731 y 867 florines) y Cataluña (5.403 y 4.658 florines), mientras que los prioratos de Castilla y Portugal no habían abonado nada en dichas anualidades. A su vez, María Bonet há confeccionado una expressiva relación de algunos de los pagos realizados al convento de Rodas por la castellanía de Amposta y, en menor medida, por otros prioratos ibéricos a lo largo de los siglos XIV y XV.

Até o final do século XIV, os tributos destinados à Rodes eram recolhidos pelo prior entre as comendas de seu priorado durante a celebração do Capítulo Provincial. Esse sistema foi modificado em 1358 quando o Capítulo Geral da Ordem do Hospital, realizado na ilha de Rodes, decidiu estabelecer em cada priorado um receptor das responsões, retirando essa obrigação das mãos do prior. Na Pensínsula Ibérica, esse receptor ou procurador dos direitos do Mestre e Convento Central correspondia a um freire do priorado, o qual muitas vezes também era comendador. Às vezes, sua jurisdição abarcava não só um priorado específico, mas toda a Península Ibérica (BARQUERO GOÑI, 2003, pp. 176-177).

Segundo Barquero Goñi (2003, p. 177):

\footnotetext{
${ }^{129}$ B.A. Regra da Ordem de S. João de Jerusalém. fls. 97-97v. "Quem não cumprisse a obrigatoriedade de presença no Capítulo Provincial pagava o dobro da responsão ao Comum Tesouro, excepto se se provasse o seu impedimento, o qual devia ser manifestado pelo seu procurador no referido Capitulo" (COSTA, 2000, p. 73).

${ }^{130}$ Além de dinheiro em espécie, os hospitalários ibéricos também chegaram a enviar animais, como afirma Carlos Barquero Goñi (2003, pp. 179-180): "Em 1300 el papa Bonifacio VIII concedió a la Orden la casa de San Miguel de Burgo, en la diócesis de Zamora, para que los freires alimentaran con sus pastos a los caballos que enviaban en apoyo de Tierra Santa. En 1311 Jaime II de Aragón mandaba a sus oficiales de Barcelona y del Vallés que dejaran salir de sus reinos a 64 caballos y 16 mulas destinados por los hospitalários a la expedición de Ultramar".
} 
Em cuanto a la fórmula que se usaba para hacer llegar los fondos a Rodas, parece ser que se utilizaban los servicios de mercaderes y banqueros, quienes se encargaban de transferir el dinero desde la Península Ibérica a la isla. En el siglo XIV suelen ser italianos, pero en la centuria siguiente encontramos ya a nativos, como mercaderes catalanes o el mercader zaragozano Pedro Torrero en 1478. En estas condiciones, no es de extrañar que muchas veces se produjeran atrasos y faltas de pago. Dentro de la Península Ibérica los que ocasionaban más problemas a este respecto parecen ser a mediados del siglo XIV los prioratos de Portugal y de Castilla. El prior castellano tenía que ordenar a su lugarteniente que quitase las bailías a los comendadores que no pagasen sus responsiones em 1357. En 1374-75 hacía nueve años que el priorato de Portugal no había pagado nada al centro de la Orden. Con todo, no eran los únicos ya que también encontramos casos en el priorato de Navarra y en la castellanía de Amposta. Em 1429 el prior de Cataluña tenía que mandar a los comendadores de su priorato que pagasen sin retraso las responsiones al tesoro común de la Orden.

Como dissemos, a falta de pagamento das contribuições ao Convento Central de Rodes podia acarretar à perda do cargo dentro da Ordem, o que aconteceu a vários priores e comendadores nos séculos XIV e XV. A situação se agravava quando as monarquias ibéricas impediam o envio das contribuições à Rodes, o que aconteceu em Portugal entre 1330 e 1345 e em Aragão em 1331 e 1332 (BARQUERO GOÑI, 2003, p. 179).

Imagem 8 - Castelo de Rodes

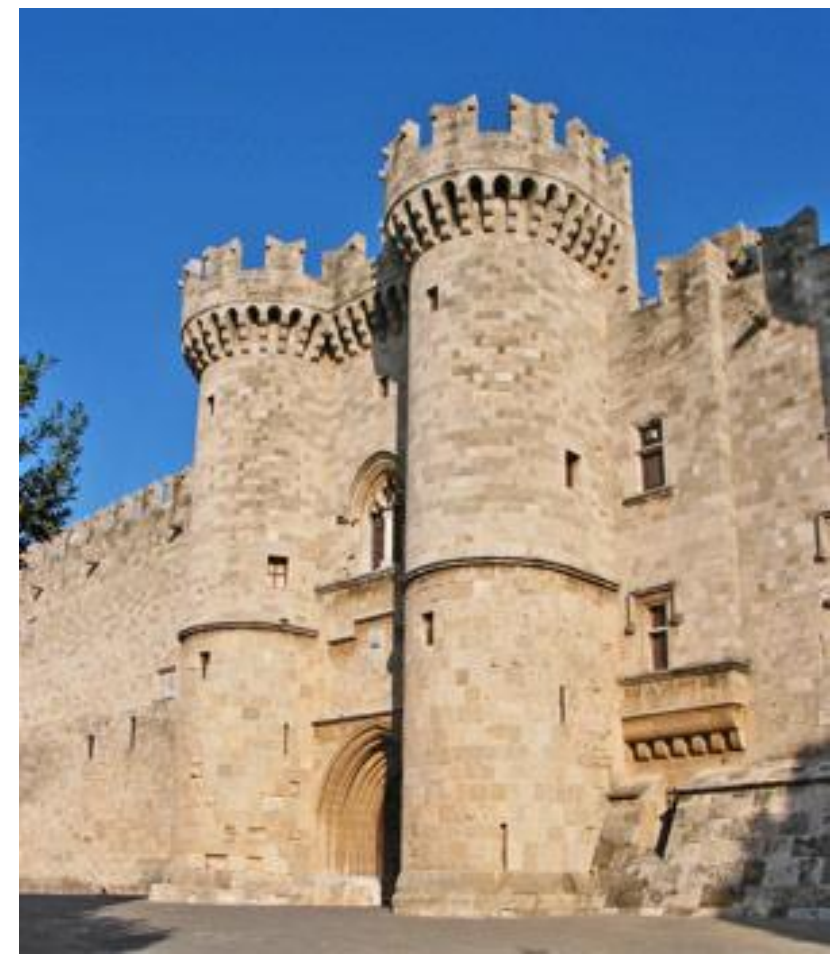

Fonte: TURISMOGRÉCIA. Castelo de Rodes. Disponível em: http://www.turismogrecia.info/guias/grecia/grecia -rodes-historia. Consultado em: 20 de março de 2015. 
Em determinados momentos era necessário que o prior recorresse ao Papa ou ao GrãoMestre, a fim de diminuir ou eliminar os impedimentos provocados por determinados reis. Observamos que quando um Prior recorria ao Papado e/ou ao Convento Central, o fazia como um meio de manter uma margem significativa de autonomia em face das interferências da monarquia. Esse recurso ao Papa e ao Grão-Mestre, por exemplo, foi feito, em Portugal, até o século XVI, quando definitivamente o Priorado do Crato foi "entregue" à família real.

La Orden de San Juan, como todas las demás Órdenes Militares, estuvo muy ligada al pontificado desde sus orígenes. Todas las Órdenes Militares en general nacieron como um brazo armado de la Iglesia directamente dependiente del papa. Originadas como una consecuencia más de la Reforma Gregoriana y del movimiento cruzado en el interior de la Iglesia, las Órdenes Militares internacionales fueron creadas como un instrumento de poder del pontificado. Es en este contexto donde debemos entender el caso de la Orden del Hospital durante los siglos XII y XIII (BARQUERO GOÑI, 2003, p. 112).

Ao longo dos séculos XIV e XV, a dependência da maioria das ordens militares com relação ao Papa começou a diminuir à medida que iam sendo incorporadas ou controladas pelas coroas europeias. No caso da Ordem do Hospital, o estreito vínculo com o Papado continuou existindo durante esse período. Depois que a Ordem do Templo foi dissolvida, a Ordem de São João passou a ser a única realmente "internacional” cujos recursos estavam disponíveis para os planos cruzadísticos que os papas mantinham no final da Idade Média. Em alguns momentos, verificamos inclusive que a liderança exercida pela Santa Sé chegou mesmo a diminuir o próprio papel exercido pelo Mestre da Ordem ${ }^{131}$.

Na Península Ibérica, o Papa atuava diretamente nos assuntos hospitalários desde o século XII. O Papado apoiou a implantação e o desenvolvimento da Ordem do Hospital nos séculos XII e XIII. Diversas foram as medidas de proteção e os privilégios concedidos, como já demonstramos em nossa dissertação de Mestrado intitulada A Ordem do Hospital no Noroeste da Península Ibérica: doações e privilégios (séculos XII-XV) (MARCHINI NETO,

\footnotetext{
${ }^{131}$ Barquero Goñi (2003, pp. 112-113) informa sobre algumas fontes para obtenção de mais informações sobre este assunto, algumas das quais não nos foi possível consultar: "N. HOUSLEY, The Avignon Papacy and the Crusades, 1305-1378, Oxford, 1986, pp. 194-198 y 260-292. A. LUTTRELL, Latin Greece, the Hospitallers and the Crusades 1291-1440, Londres, 1982, I, pp. 252, 256-257. A. LUTTRELL, The Hospitallers of Rhodes and their Mediterranean World, Aldershot, 1992, I, pp. 6-7. S. MENACHE, The Hospitallers during Clement V's pontificate: the spoiled sons of the Papacy?, en H. Nicholson (ed.), The Military Orders. Volume 2. Welfare and Warfare, Aldershot, 1998, pp. 153-162. J. DELAVILLE LE ROULX, Les Hospitalliers à Rhodes jusqu'à la mort de Philibert de Naillac (1310-1421), París, 1913, pp. 19-26, 57-59, 125-126, 129-134, 142-144, 170-175, 323-325".
} 
2010, pp. 78-84). Além disso, os papas exercem o controle supremo sobre a Ordem na Península Ibérica e regulam suas relações com o restante da Igreja.

\subsection{PRIVILÉGIOS CONCEDIDOS PELA SANTA SÉ}

A Igreja mantinha uma relação estreita com a Ordem do Hospital. O Papa era o responsável máximo pela Ordem, pois esta era diretamente dependente do Papado. Assim sendo, o Sumo Pontífice fez várias intervenções em assuntos de funcionamento dos Hospitalários, como por exemplo, na provisão do Priorado e das comendas (COSTA, 2000, p. 133). Por diversas vezes, o Papa também interferiu para proteger os freires da ação direta dos bispos que pretendiam controlar os elementos da Ordem situados dentro da área jurisdicional de sua diocese.

Precisamos remontar à bula Pie Postulatio de Pascoal II, datada de 15 de fevereiro de 1113, para verficarmos que desde o momento em que a Ordem do Hospital fora confirmada pela cúria romana já há uma concessão papal em questões jurisdicionais. Desta forma, verifica-se nesta bula que a dependência da Ordem de São João era para com a cúpula hierárquica da Igreja, ficando a Ordem, por isso, isenta da jurisdição dos bispos.

De acordo com Luis García-Guijarro Ramos (1995, p. 124), a questão dos privilégios jurisdicionais da Ordem do Hospital radica, além da bula de Pascoal II, de outras quatro bulas emanadas por papas posteriores ao citado. Uma dessas bulas, de 16 de junho de 1135 , vinculava a sujeição do patrimônio da Ordem aos grão-mestres e à Santa Sé, não podendo os bispos ferir com interdito as igrejas. Outra bula, Christiane fidei religio, de 7 de fevereiro de 1137, de Inocêncio II, estipulava que as coletas da Ordem dominavam sobre o interdito episcopal, ressalvando, desta forma, a recolha de esmolas por parte dos freires uma vez por ano, mesmo nas igrejas que estivessem localizadas em zonas que se encontrassem sob interdito. Além disso, por este documento, o Papa ainda estendia os efeitos da proteção apostólica a pessoas diretamente relacionadas com os hospitalários (COSTA, 2000, pp. 136137).

A terceira bula, Quam amabilis Deo, criticamente datada como pertencente aos anos entre 1139 e 1143, admitia a possibilidade de clérigos diocesanos servirem de forma temporária na Ordem, com autorização dos bispos e conservando seus benefícios. Uma última bula, Christiane fidei, de 1154, expedida por Anastácio IV, autorizou a Ordem do Hospital a 
dispor de clero próprio, "resolvendo teoricamente a contradição patente na dependência dos bispos quanto aos ofícios religiosos". Ainda segundo García-Guijarro Ramos, o Papa Anástácio IV não criou este clero próprio, mas apenas criou condições para que fossem libertados da ação diocesana (1995, pp. 128-133).

Segundo Paula Pinto Costa (2000, p. 138):

A aplicação das penas eclesiásticas era outro elemento perturbador do relacionamento entre a Ordem e os bispos. Tanto a excomunhão, que recai sobre pessoas, como o interdito, que se aplica a lugares eclesiásticos, constituíram pontos de divergência entre ambos. Os Hospitalários reclamavam o exercício destas prerrogativas e, em consequência, o Papa Eugénio IV, através da bula Et si Apostolicae Sedis, datada de 1434, reiterou a anuência às pretensões do Instituto.

Diante disso, os freires do Hospital não mantiveram, numa perspectiva generalizada, uma convivência pacífica com os bispos, e frequentemente entravam em controvérsia com os prelados diocesanos, pois os comendadores não estavam dispostos a reconhecer as autoridades desses clérigos, "neste sentido, o pagamento dos diversos direitos episcopais motivou situações de conflito aberto entre ambos, a par da insatisfação resultante das visitações episcopais" (COSTA, 2000, p. 133).

A cobrança de direitos episcopais foi outro tema de intensos conflitos entre os freires da Ordem e as dioceses. Os dízimos e outros diversos tributos de natureza similar eram frequentemente disputados por ambas as partes. A Ordem do Hospital alegava ser isenta do pagamento de dízimos e de outros direitos episcopais que afetassem pessoas e bens a ela pertencentes, considerando o fato de se encontrar diretamente dependente do Sumo Pontífice.

No entanto, o IV Concílio de Latrão, celebrado em 1215, restringiu estas exacções, permitindo que em tempos próximos, os bispos onerassem os bens da Ordem. Os Hospitalários foram céleres em reclamar os seus direitos, motivando a expedição de novas bulas que reiteravam a tão almejada isenção (COSTA, 2000, pp. 138-139).

Outra questão que também causou imensas discussões e conflitos entre a Ordem do Hospital, os bispos, os reis e os Papas foi o problema do direito de padroado. Esse direito, que possuíam diferentes senhores (relativamente a igrejas), dispunha que seu possuidor poderia apresentar ao bispo "o clérigo que deveria presidir aos destinos espirituais do benefício, se fosse curado, ou exercer um ofício sem cura que lhe dava o direito à percepção dos réditos beneficiais" (MARQUES, p. 1073 apud COSTA, 2000, p. 150). O direito de padroado e de apresentação exercidos pela Ordem do Hospital, em diversas ocasiões, foi confirmado através 
de documentos pontifícios. Exemplos relacionados com estas matérias poderão ser encontrados nas páginas seguintes.

No século XV, Inocêncio VIII confirmou os privilégios de isenção da Ordem do Hospital, assim como foi feito pelo Papa Pio IV, no século seguinte. Nos séculos XV e XVI, diversas bulas papais foram expedidas relativas a este tema, o que nos leva a refletir sobre a dimensão real deste problema.

Na parte final da Regra da Ordem de São João de Jerusalém, documento que transcrevemos parcialmente, encontram-se privilégios concedidos pelos seguintes papas aos Hospitalários: Martinho V (1417-1431), Sisto IV (1471-1484), Inocêncio VIII (1484-1492), Leão X (1513-1521), Clemente VII (1523-1534), Paulo III (1534-1549) e Pio IV (1559$1565)^{132}$. Abaixo, citaremos os principais privilégios registrados neste códice, concedidos pelos referidos pontífices.

Consta do fólio 245 da Regra da Ordem de São João de Jerusalém que o Papa Martinho V:

Concedeo a Ordem que todas as querellas, questõis, demandas, causas e controversias nacidas de quaisquer occasiõis entre os frades e súbditos do Hospital de São João sejão julgados ate sentença diffinitiva pelo Grão Mestre e convento, ou pelos frades a que pelo Grão Mestre e convento forem cometidos. Visto com todos seus incidentes, anexos e connexõis e sem appellação. E poderão ser ouvidos pelos ditos juizes comissarios ou Grão Mestre e convento ata a terceira sentença diffinitiva so poderão appellar pera a See Appostolica em casso que se lhe não averde a justiça nem se guardem os estabelicimentos e costumes da Ordem ${ }^{133}$.

No final, Martinho V ainda autoriza a possibilidade de excomunhão daqueles freires ${ }^{134}$ e súditos da Ordem que, por estarem em locais distantes da Sé Apostólica, apelarem a outros juízes, e afirma que pelo mesmo caso esses perderiam a causa e a coisa sobre o que litigassem.

No registro referente ao privilégio de Sisto IV, verifica-se que o Papa "concedeo que todas as collaçõis, provisõis, uniõis, annexaçõis e incorporaçõis ou quaisquer outras concessõis das comendas e mais benefícios da Ordem não vallesem, posto que fosem dadas pela See Appostolica se não dando as o Grão Mestre e convento" ${ }^{135}$. Neste registro, Sisto IV ainda declara que aqueles que adquirissem comendas e benefícios de outra forma, diferente da citada, seriam excomungados diretamente pela Santa Sé. E se fossem freires que

132 B.A. Regra da Ordem de São João de Jerusalém. 49-II-32, fólios 245-250.

${ }^{133}$ B.A. Regra da Ordem de São João de Jerusalém. 49-II-32, fólios 245-245v.

134 O termo correto é "freires" e não "frades" como aparece na fonte com que trabalhamos.

135 B.A. Regra da Ordem de São João de Jerusalém. 49-II-32, fólios 245v-246. 
desobedecessem e tivessem os ditos benefícios por mero um mês, perderiam tudo o que possuíssem da Ordem e ainda seriam punidos pelo Grão-Mestre da instituição.

Sobre Inocêncio VIII, consta da Regra da Ordem de São João que este Papa:

Concedeo que nhũa excepção escusasem aos religiosos da obediencia e pagamento das responsõis ao comum thesouro. E que os beneficios da Ordem posto que vagasem na See Appostolica se provesem pelo Grão Mestre e convento e não entendesem nelles as reservas e que os privilegios em contrario concedidos não valhão nem os que se proverem contra esta determinação tenham nelles posse, dereito nem titolo corado, nem lhes valha a regra de trienali possessioem ${ }^{136}$.

Há ainda a menção de que o Papa Júlio II tenha confirmado as indulgências e privilégios que todos os Sumos Pontífices anteriores concederam aos Hospitalários ${ }^{137}$.

Já Leão X concedeu ao grão-mestre o direito de nomear em cada priorado da Ordem um vigário geral, "que pudese dar beneficios da Ordem e ansianidades e por em elles as pensois e responsõis ao diante ditas(?) e dispensar na idade e defecto de nacimento com os inhabeis pera os beneficios da Ordem soomente". Leão X ainda exalta o valor das decisões do grão-mestre e Convento, pedindo que se desse crédito às "letras" do líder da milícia "tanto que fossem expendidas fiquasem logo confirmadas". Por fim, este pontífice ainda proíbe que sejam colocados encargos nos benefícios da Ordem, ainda que estes encargos sejam estipulados por "emperadores, reis, cardeais, prelados, duques, princepes, marquezes e universidades" ${ }^{\prime 138}$.

Ainda analisando a parte final da Regra da Ordem de São João de Jerusalém ${ }^{139}$, verificamos que o Papa Clemente VII ${ }^{140}$ concedeu ao Grão-Mestre plena "jurisdição de mero e mixto império nas pessoas e bens da Ordem e faculdade pera proceder contra os reveis e contumazes e os privar dos beneficios, redditos e fruitos e os arendar posto que sejão pessoas seculares ou regulares de outra ordem tendo beneficios da Ordem" "141. O Papa ainda autorizou a publicação de indulgências concedidas pela Santa Sé sem licença dos prelados ordinários, bastando terem o selo do prior da província respectiva ou do conservador da Ordem, permitindo que a Ordem tivesse adros nas suas igrejas paroquiais, onde, em tempo de interdito, pudesse enterrar todas as pessoas, ressalvando o direito do reitor ou do cura; os

\footnotetext{
${ }^{136}$ B.A. Regra da Ordem de São João de Jerusalém. 49-II-32, fólio 246.

${ }^{137}$ B.A. Regra da Ordem de São João de Jerusalém. 49-II-32, fólio 246.

${ }^{138}$ B.A. Regra da Ordem de São João de Jerusalém. 49-II-32, fólios 246-246v.

${ }^{139}$ B.A. Regra da Ordem de São João de Jerusalém. 49-II-32, fólios 246v-249.

${ }^{140}$ Clemente VII foi um antipapa de Avinhão.

141 “A plena jurisdição estava consubstanciada na expressão de 'mero e mixto imperio'. Os direitos senhoriais eram um meio muito eficaz para fazer sentir aos dependentes a autoridade de que gozava o senhor" (COSTA, 2000 , p. 159).
} 
membros da instituição podiam receber sacramentos em quaisquer igrejas e receber ordens sacras das mãos de qualquer bispo; os capelães da Ordem poderiam confessar os membros da milícia, bem como os vassalos, súditos e familiares e administrar-lhes os sacramentos; os capelães ainda poderiam celebrar ofícios em tempo de interdito, em voz baixa, sem presença dos excomungados e com as portas do templo fechadas; os Hospitalários podiam construir igrejas da Ordem em qualquer parte da Cristandade, garantindo-lhes sustentação conveniente; as igrejas e religiosos da instituição, assim como seus bens, súditos, vassalos, lavradores e criados eram postos sob proteção apostólica e isentos de qualquer outra jurisdição, que não fosse a da Religião (COSTA, 2000, p. 141). Referente aos privilégios concedidos por Clemente VII, também é interessante citar:

E que sejão livres de todo o tributo pasagii, arreagii, gabellae, datii, traetae, collectae, procurationis, iacunali adventus, iurium etiam sinodalium sensuis(?) et decimarum etiam novalium et hortorum, pratorum, piscatiorum et molendinorum. Concedeo que não tivesem nas sobredictas jurisdição ( sic) os prelados nem ordinarios, nem ainda rationem delictio contractos contra o qual não val a prescripção em contrario o que tudo guardarão os prelados sob pena de excomunham santae sententiae. Encorrem ipso facto em restituição do dano que nisso derem as partes em quatro dobro ${ }^{142}$.

O Papa Paulo III, além de ter confirmado todos os privilégios concedidos pelos seus antecessores, ainda determinou que

Bens da Ordem se não desem em prazo perpetuo ou tatiosim se não em três vidas e os que fossem dados em tatiota não vallesem mais tempo que noventa e nove anos. E que querendo o Grão Mestre ou os priores e bailios e mais religiosos, os beneficios que sempre andarão em clerigos seculares os pudesem dar a clerigos do habito de São João ${ }^{143}$.

A última menção a um privilégio pontifício na Regra da Ordem de São João é referente às concessões feitas pelo Papa Pio $\mathrm{IV}^{144}$. Este Papa confirmou os demais privilégios da Ordem e também proibiu as apelações a outros juízes, senão aos da instituição, determinando como última instância o Capítulo Geral. Além disso, o pontífice também consentiu que os priores fossem ordinários em seus priorados, ou seja, que tivessem poderes iguais aos que os bispos tinham nas dioceses. Desse registro ainda podemos citar:

${ }^{142}$ B.A. Regra da Ordem de São João de Jerusalém. 49-II-32, fólios 246v-249.
${ }^{143}$ B.A. Regra da Ordem de São João de Jerusalém. 49-II-32, fólios 249-249v.
${ }^{144}$ B.A. Regra da Ordem de São João de Jerusalém. 49-II-32, fólios 249v-250. 
Concedeo que todas as sentenças, comissõis, citaçõis e rescriptos do Grão Mestre e convento se dem a execução sem mais informação e consentimento algum dos prelados. E se proceda contra os seculares e regulares que deverem a Ordem assi como se proceda contra os religiosos da Ordem. E que os conservadores da Ordem gozem dos privilegios della. Concedeo que os religiosos da Ordem e seus capellães onde quer que estiverem não paguem dizimas nenhũas, imposiçõis ou subsidios de seus beneficios concedidos assi em Espanha como França. E que possão levar livremente os fruitos das comendas onde quer que quiserem sem pagar dereitos alguns. Concedeo que nenhũa cousa se entendese julgada em perjuizo do convento sem pera isso ser chamado.

Estes privilégios concedidos à Ordem do Hospital pela Santa Sé abrangiam a instituição como um todo, obviamente incluindo os Hospitalários portugueses que, desde o século XII, gozavam de prerrogativas importantes sobre questões jurisdicionais ${ }^{145}$.

Segundo Paula Pinto Costa (2000, p. 140),

No Priorado do Crato houve diversos momentos em que a delimitação de áreas de jurisdição espiritual e a consequente percepção de rendimentos eclesiásticos originaram diferendos entre os freires e os bispos, chegando a gravidade de alguns deles a exigir a intervenção papal, com vista à sua resolução.

É necessário, entretanto, observarmos que os Hospitalários, assim como os bispos, dependiam diretamente da cúria romana, sendo este o motivo principal dos recursos à cúpula da Igreja.

No Livro de Herdamentos e Doações do Mosteiro de Leça verificam-se vários registros referentes a privilégios pontifícios, sendo muitos desses registros comprovações de que os papas tiveram que, por diversas vezes, interferir nos problemas relacionados à jurisdição e direito de padroado. Neste aspecto podemos citar:

Item privilegio d'Onorio III $^{\mathrm{o}}$ papa per que nenhuum prelado nom ponha sentença d'escomunhom nem entredicto nos freyres e clérigos do Espital em que nom ha outoridade. <Ca o papa nom quer que outrem os julgue se nom $\mathrm{el}^{146} .>$

Item privilegio de papa Innocencio $\mathrm{III}^{\circ}$ en que tanje cinco cousas. A primeira he quem se apoderar dos beens dos beens (sic) e possissoens do Espital ou dos fruytos d'elas ou dos seus homeens sen lhys fazendo d'elas reverença. A segunda he quem filhar sen dereito os beens que fossen leyxados en testamento aa Ordem. A terceyra he quem posser sentença en nos freyres. A

\footnotetext{
145 Ainda de acordo com Paula Pinto Costa (2000, p. 140), "no reino de Portugal, fez sentir-se bem alto o eco dos problemas decorrentes do exercício da jurisdição diocesana, sobretudo quanto ao pagamento dos direitos episcopais, como aliás, aconteceu em outros reinos ibéricos".

${ }^{146}$ A.N.T.T., Colecção Costa Basto, Livro dos Herdamentos e Doaçães do Mosteiro de Leça, $\mathrm{n}^{\circ}$ 4, fólio 1.
} 
quarta he quem d'eles levar a dizima dos fruytos que ouverem per seus trabalhos ou a dizima das sas crianças que os bispos os escumungem ataa qui lhy satifaçam. A quinta he quem lançar en eles mãaos violentas seja escumungado e nom possa seer asolto se nom pelo papa ${ }^{147}$.

Item privilegio d'Aleyxandre quarto en que fala que os prelados nom demandem mays dos seus dereitos aa Ordem dos que ouverom ata aqui ${ }^{148}$.

Item privilegio de Gregório $\mathrm{IX}^{\mathbf{0}}$ en que manda que se os freires do Spital filharem algũas terras aos enemiigos da fé que posam en elas edificar igrejas e estas igrejas nom sejam sujeitas se nom ao papa ${ }^{149}$.

Item privilegio d'Aleyxandre quarto en que diz que o Spital possa reteer os beens das igrejas en que nom quiserem confirmar os freyres ou os seus clerigos e dar o seu dereito ao prelado e esto se entende nas casas da Ordem en que ha igrejas que nom forom abadadas ${ }^{150}$.

Item privilegio d'Onorio $\mathrm{III}^{\mathrm{o}}$ en que manda que ecriebam ( $\mathrm{sic}$ ) os prelados os clerigos ydoneos que lhis a Ordem presentar e posto que estes clerigos nom sejam tan ydoneos come outros que se hy apresentarem que os nom leyxem por ende confirmar nas sas igrejas. Outrossi que nom ponham sentença nos freires nem nos clerigos da Ordem ${ }^{151}$.

Item privilegio d'Aleyxandre IIII $^{\circ}$ en que diz que nenhuum prelado nom possa poer sentença nos freires nem nos sergentos do Espital, quer eclesiasticos quer segraes sem mandando special do papa e confirma aa dicta hordem hos privilegios dos seus predecesores, e por sentença que en eles ponham que nom leyxem porem de reger sas oras e dar e receber os sacramentos da Sancta Eglesia ${ }^{152}$.

Privilegio de Celestino papa $\mathrm{III}^{\circ}$ en que outorga aos freires do Spital que posam tomar por freires en sa Ordem quem lhis prouver e que os prelados nom lhis dem embargo sobr' esto $^{153}$.

Também no códice de Leça verificamos registros que mencionam privilégios régios relacionados à proteção de determinadas terras e bens da Ordem; proteção aos homens da instituição ${ }^{154}$; e isenção de pagamento de rendas, tributos e dízimas a prelados em geral, a

\footnotetext{
${ }^{147}$ A.N.T.T., Colecção Costa Basto, Livro dos Herdamentos e Doaçães do Mosteiro de Leça, $\mathrm{n}^{\circ} 4$, fólio 1.

148 A.N.T.T., Colecção Costa Basto, Livro dos Herdamentos e Doações do Mosteiro de Leça, $\mathrm{n}^{\circ}$ 4, fólio 2. Da mesma forma agiram os Papas Alexandre IV, Honório III, Clemente IV e Inocêncio IV, fólios 6 e 17.

${ }_{149}$ A.N.T.T., Colecção Costa Basto, Livro dos Herdamentos e Doaçães do Mosteiro de Leça, $\mathrm{n}^{\circ}$ 4, fólio 2.

${ }^{150}$ A.N.T.T., Colecção Costa Basto, Livro dos Herdamentos e Doaçães do Mosteiro de Leça, $\mathrm{n}^{\circ} 4$, fólio 2.

${ }^{151}$ A.N.T.T., Colecção Costa Basto, Livro dos Herdamentos e Doaçães do Mosteiro de Leça, $\mathrm{n}^{\circ} 4$, fólio 2.

${ }^{152}$ A.N.T.T., Colecção Costa Basto, Livro dos Herdamentos e Doaçães do Mosteiro de Leça, $\mathrm{n}^{\circ}$ 4, fólio 2.

153 A.N.T.T., Colecção Costa Basto, Livro dos Herdamentos e Doações do Mosteiro de Leça, ${ }^{\circ}$ 4, fólio 16. Neste códice existe ainda um registro que alega que o Papa Celestino III ordenou que os prelados não embargassem os homens que quisessem ser aceitos na Ordem do Hospital como freires, assim como aqueles que a própria Ordem quisesse tornar freire, fólio 4.

${ }^{154}$ Alguns destes privilégios também tratavam de questões relacionadas à jurisdição civil. A.N.T.T., Colecção Costa Basto, Livro dos Herdamentos e Doações do Mosteiro de Leça, $\mathrm{n}^{\circ}$ 4, fólios 1, 2, 3, 5 e 16, referentes aos privilégios dos Papas Inocêncio IV, Celestino III, Gregório VIII, Lúcio III, Inocêncio III e Inocêncio (não especifica qual).
} 
senhores, a reis e aos próprios papas ${ }^{155}$. Em muitos desses registros, alega-se que os papas determinavam que os freires e demais pessoas ligadas à Ordem fossem julgados internamente, por autoridades hospitalárias. Em outros registros, os papas ameaçam excomungar os clérigos e demais particulares que desobedecessem a suas ordens e ameaçassem sua proteção à Ordem do Hospital ${ }^{156}$.

Além dos privilégios anteriormente mencionados, no Livro de Herdamentos $e$ Doações ainda encontramos, em vários registros, confirmações papais acerca dos privilégios e liberdades da Ordem do Hospital. Nos fólios transcritos nesta tese (vide Anexo 1), verificamos que os seguintes papas, que exerceram os respectivos pontificados entre os séculos XIII e XIV, fizeram este tipo de confirmação: Alexandre IV ${ }^{157}$, Clemente $\mathrm{V}^{158}$, João XXII ${ }^{159}$, Clemente II $^{160}$, Bonifácio VIII ${ }^{161}$, Bento XII ${ }^{162}$, Nicolau III ${ }^{163}$, Gregório XI ${ }^{164}$, Bento $\mathrm{XI}^{165}$, Inocêncio III $^{166}$ e Inocêncio IV $^{167}$. O texto dessas confirmações é praticamente o mesmo nos diversos registros relacionados; sendo assim, citamos apenas um exemplo: "Item privilegio de Clemente papa $I^{o}$ en que confirma os privilegios dos antecessores e outrossi as liberdades e privilegios dados ao Spital pelos reys e principes" ${ }^{168}$. Este enunciado breve aponta para uma confirmação geral de privilégios, embora não seja possível aferir com rigor de que benesses se tratam.

Ainda no que diz respeito às relações entre o Priorado do Crato e o Papado, podemos, portanto, afimar que durante o século XV, tempo em que vivera D. Vasco de Ataíde, houve um ambiente de convergência dos interesses da Santa Sé e da Ordem do Hospital, o que vinha quase sempre a coincidir com interesses da Coroa Portuguesa.

O Papa Calisto III, por exemplo, através da bula Et si cuncti, e com a intenção de promover a defesa e o reforço da presença dos portugueses em Ceuta, ordenou, no ano de

${ }^{155}$ A.N.T.T., Colecção Costa Basto, Livro dos Herdamentos e Doações do Mosteiro de Leça, $\mathrm{n}^{\circ}$ 4, fólios 1, 3, 4, 6, 16 e 17, referentes aos privilégios dos Papas Inocêncio III, Bonifácio VIII, Gregório X, Clemente IV, Honório III, Gregório VIII e Celestino (não especifica qual).

${ }_{156}$ A.N.T.T., Colecção Costa Basto, Livro dos Herdamentos e Doações do Mosteiro de Leça, $\mathrm{n}^{\circ}$ 4, fólios 1, 2, 3, 5 e 16, referentes aos privilégios dos Papas Inocêncio IV, Celestino III, Gregório VIII, Lúcio III, Inocêncio III e Inocêncio (não especifica qual).

${ }_{157}$ A.N.T.T., Colecção Costa Basto, Livro dos Herdamentos e Doaçães do Mosteiro de Leça, $\mathrm{n}^{\circ}$ 4, fólio 2.

${ }_{158}$ A.N.T.T., Colecção Costa Basto, Livro dos Herdamentos e Doações do Mosteiro de Leça, $\mathrm{n}^{\circ} 4$, fólio 2.

${ }_{159}$ A.N.T.T., Colecção Costa Basto, Livro dos Herdamentos e Doaçães do Mosteiro de Leça, $\mathrm{n}^{\circ} 4$, fólio 3.

160 A.N.T.T., Colecção Costa Basto, Livro dos Herdamentos e Doações do Mosteiro de Leça, $\mathrm{n}^{\circ}$ 4, fólio 4.

${ }^{161}$ A.N.T.T., Colecção Costa Basto, Livro dos Herdamentos e Doaçães do Mosteiro de Leça, $\mathrm{n}^{\circ}$ 4, fólio 4.

162 A.N.T.T., Colecção Costa Basto, Livro dos Herdamentos e Doaçães do Mosteiro de Leça, $\mathrm{n}^{\circ} 4$, fólio 6.

163 A.N.T.T., Coleç̧ão Costa Basto, Livro dos Herdamentos e Doações do Mosteiro de Leça, $\mathrm{n}^{\circ}$ 4, fólio 16.

164 A.N.T.T., Colecção Costa Basto, Livro dos Herdamentos e Doações do Mosteiro de Leça, $\mathrm{n}^{\circ}$ 4, fólio 16.

${ }^{165}$ A.N.T.T., Colecção Costa Basto, Livro dos Herdamentos e Doações do Mosteiro de Leça, $\mathrm{n}^{\circ}$ 4, fólio 17.

166 A.N.T.T., Colecção Costa Basto, Livro dos Herdamentos e Doaçães do Mosteiro de Leça, $\mathrm{n}^{\circ} 4$, fólio 5.

167 A.N.T.T., Colecção Costa Basto, Livro dos Herdamentos e Doações do Mosteiro de Leça, $\mathrm{n}^{\circ}$ 4, fólios 17-18.

${ }^{168}$ A.N.T.T., Colecção Costa Basto, Livro dos Herdamentos e Doações do Mosteiro de Leça, $\mathrm{n}^{\circ}$ 4, fólio 4. 
1456, que as quatro ordens militares existentes em Portugal fundassem um convento naquela localidade africana. Além disso, os líderes dessas ordens deveriam enviar anualmente um terço dos seus freires, para colaborarem na defesa desta praça. O custo desta empreitada seria pago pelas próprias ordens ${ }^{169}$. Posteriormente, em 1462, outro Papa, Pio XII, reafirmou as exigências de Calisto III, mas dessa vez não incluía os hospitalários, referindo-se apenas aos freires das ordens de Avis, Cristo e Santiago ${ }^{170}$, o que diante de tantas exigências feitas por Calisto III, poderia representar algo positivo. Dois anos depois, em 16 de setembro de 1464, o Papa Paulo II expediu uma nova bula, Rationi congruit, revogando a bula de Calisto III, sobre a fundação dos conventos em Ceuta. Oito anos depois, em 1472, o Papa Sisto IV, através da bula Olim siquidem, aprovou revalidou as exigências de Calisto III, exceto no que se refere à participação da Ordem do Hospital ${ }^{171}$.

A respeito disso, Paula Pinto Costa escreveu o seguinte (2000, p. 219):

Esta medida pontifícia tão drástica deve radicar uma súplica feita por D. Afonso V, apesar de não ser conhecida na actualidade. Esta atitude do Sumo Pontífice prende-se diretamente com a perda de Constantinopla, em 1453, e com a vontade de Calisto III, eleito dois anos mais tarde, em desenvolver um projecto de Cruzada, através do qual o povo cristão teria a possibilidade de reaver esta cidade tão importante.

A isenção à Ordem do Hospital da exigência de fundação de tal convento em Ceuta, pode ter acontecido como uma maneira de o Papado demonstrar aos sanjuanistas, principalmente os de Portugal, que a Santa Sé reconhecia o empenho dos hospitalários na defesa da Cristandade, principalmente no que diz respeito à atuação da Ordem no Mediterrâneo Oriental. Pode ter colaborado para isso, a forma diferente de exercer controle sobre o Priorado do Crato, encontrada pela monarquia portuguesa, não a incorporando na Coroa, como aconteceu com as ordens de Avis, Cristo e Santiago.

Além disso, vale lembrar que Afonso $\mathrm{V}$ tinha intervindo junto do Papa a fim de demonstrar o quão era inviável a fundação de tais conventos na África. Por fim, o Papa pode também ter levado em consideração a própria pessoa de D. Vasco de Ataíde ou a influência de outros hospitalários de família nobre. Na mentalidade da nobreza portuguesa do século $\mathrm{XV}$, morar na África era um desprestígio, além do risco de talvez nunca mais voltar, tendo em vista $\mathrm{o}$ risco de ataques que existia nas praças conquistadas naquele continente.

\footnotetext{
${ }^{169}$ A.N.T.T., Gavetas VII, m. 7, $\mathrm{n}^{\mathrm{o}} 23$ e Monumenta Henricina, Vol. 12, doc. 116.

${ }^{170}$ Monumenta Henricina, vol. 15, doc. 34.

${ }^{171}$ Monumenta Henricina, vol. 15, doc. 34.
} 
Provavelmente, a pressão dos nobres ligados a essas ordens militares deve ter levado D. Afonso V a escrever a súplica ao Papa. Conquistar a África era uma honra, morar lá não.

Sobre este assunto, também discorreu Paula Pinto Costa em uma de suas obras (2000, p. 220):

Na sequência da bula Et si cuncti de Calisto III, de 1456 e da respectiva confirmação feita por Pio II, em 1462, o infante D. Fernando e os membros das Ordens de Avis, Santiago e Cristo expuseram ao Papa Pio II as razões que impediam que os conventos das Ordens Militares fossem edificados em África. Assim, eram alegados factores como a distância territorial entre o reino e o continente africano, a pouca força das Ordens, a utilidade das terras africanas servindo os interesses do rei, o acolhimento que estas instituições davam aos filhos dos reis, os privilégios apostólicos e régios e o desprestígio que representava para alguns membros de famílias nobres morar em África. $\mathrm{Na}$ verdade, cremos que estas razões terão também contribuído para que a obrigação de construção de um convento no referido continente, deixasse de se aplicar aos freires de S. João (Publ. Descobrimentos Portugueses... vol. 3, doc 31, pp. 45-49).

Podemos citar outra intervenção da Santa Sé em favor dos hospitalários de Portugal. Em 22 de junho de 1482, o Papa Sisto IV expediu uma bula, através da qual ordenava ao bispo e ao chantre de Évora que permitissem a permuta de bens que existiam naquela diocese, entre D. João II e a Ordem do Hospital, atendendo a uma súplica apresentada pelo monarca ${ }^{172}$. Os reis não podiam trocar bens (fazer escambos) patrimoniais com os hospitalários sem o consentimento do Papa, pois os bens das ordens militares eram tidos como patrimônio de Cristo e, por isso, precisavam passar por juízos eclesiásticos antes de serem permutados com soberanos.

Com essa análise, percebemos que a Santa Sé ao mesmo tempo em que utilizava a Ordem do Hospital para alcançar seus objetivos de se defender e ao mesmo atacar forças islâmicas, também interferia nos assuntos internos dos priorados a fim de solucionar questões ou regulamentar temas acerca da relação entre os hospitalários, soberanos e bispos. E, em muitos momentos, o Papado concedeu privilégios que atendiam positivamente as necessidades dos freires. Além de tudo, a Ordem do Hospital servia como uma espécie de exército próprio da Santa Sé.

172 A.N.T.T., Gavetas VI, m. ún., no 215 e 217. Breves Liv. 1, fls. 106-107v. Segundo Paula Pinto Costa (2000, p. 223), "esta bula de Sisto IV de 1482 tem inserta uma cópia de umas letras pontifícias de Paulo II, do ano de 1465, das quais consta a justificação teórica de carácter eclesiástico, que sustentava os contratos de escambo onde estivessem envolvidas pessoas sujeitas ao foro eclesiástico. No caso concreto desta permuta, Sisto IV especifica que por este acto são ultrapassadas, tanto as constituições e ordenações apostólicas como os estatutos, costumes e usos e estabelecimentos do Hospital". 
Igreja e Papado constituíram para as ordens militares uma imprescindível fonte de legitimação. Concederam uma garantia de proteção jurídico-canônica para seus freires e para seu patrimônio. Foram ainda uma referência de controle sobre sua própria realidade institucional, além de terem exercido um papel de arbitragem reiteradamente demandado pelos próprios freires. Proteção, legitimação, arbitragem e controle foram as principais ações da Igreja sobre as ordens militares (AYALA MARTÍNEZ, 2007, pp 776-783).

\subsection{A POSSÍVEL ALIANÇA ENTRE O PRIOR DO CRATO E O PRIOR DO HOSPITAL EM CASTELA: A BATALHA DE TORO (1476)}

Os hospitários dos reinos ibéricos vizinhos de Portugal se encontravam envolvidos em vários dos conflitos militares no reinado de Isabel e Fernando. Um desses conflitos chama nossa atenção pelo fato de envolver hospitalários não só de Castela, mas também de Portugal. É o caso da guerra de sucessão pelo trono castelhano ocorrida após a morte de Henrique IV (1475-1476). Nessa guerra sabemos que houve a participação do Prior Hospitalário de Castela D. Álvaro de Estúñiga, a favor dos Reis Católicos. Como recompensa, os monarcas o ajudaram a consolidar-se no priorado.

Do lado oposto estava o prior castelhano antecessor D. Juan de Valenzuela, aliado do rei de Portugal. Fato interessante é que o alcaide que Valenzuela havia colocado na fortaleza hospitalária de Castronuño desempenhou um papel importante na guerra, protagonizando uma forte resistência frente às forças de D. Fernando. Hospitalários portugueses também participaram do conflito ao lado do seu monarca, dando certo suporte à resistência de D. Juan de Valenzuela. Contudo, após a derrota dos opositores dos Reis Católicos, o antigo prior Valenzuela sofreu a confiscação de seus bens até ser perdoado em virtude do tratado de paz com Portugal, em 1479 (BARQUERO GOÑI, 2003, p. 231).

Vamos aprofundar mais essa análise para compreendermos de que maneira os problemas dos Priores de Castela se relacionaram com o Prior do Crato, D. Vasco de Ataíde.

Em Castela, a instabilidade política do final do reinado de Henrique IV propiciou a aparição de um autentico cisma no Priorado da Ordem do Hospital daquele reino. Em 1475, Juan de Valenzuela, até então favorito do monarca castelhano, havia sido nomeado Prior do Hospital. Valenzuela era uma pessoa que gozava da plena confiança de Henrique IV. Até 
mesmo quando a maior parte da nobreza castelhana se revoltou contra o monarca em 1465, o Prior se manteve fiel a Henrique IV e tentou lutar contra a rebelião.

Contudo, ao final foi derrotado militarmente e perdeu o controle da maior parte do Priorado. Como resultado dessa perda, o Prior de Castela ficava incapacitado de continuar pagando as contribuições que devia enviar anualmente ao Mestre e Convento Central da Ordem de São João em Rodes. Por este motivo, em 1470 dois delegados do Mestre do Hospital chegaram à Castela e destituíram o Prior Juan de Valenzuela de seu cargo. Designaram para seu lugar D. Álvaro de Estúñiga, que pagou fielmente as contribuições devidas por Valenzuela. Assumia o poder do Priorado de Castela uma das mais importantes linhagens da nobreza castelhana, os Estúñiga ou Zúñiga (BARQUERO GOÑI, 2006 pp. 31 32).

Como consequência de sua destituição, Juan de Valenzuela, inconformado, iniciou uma luta violenta entre os envolvidos na posse do Priorado. Os grupos que disputavam o poder político nos últimos anos do reinado de Henrique IV imediamente se alinharam a um dos candidatos ao Priorado. Os ainda príncipes Fernando e Isabel apoiaram Álvaro de Estúñiga, enquanto Juan de Valenzuela recebeu ajuda do influente Marquês de Villena, Juan Pacheco. Em 1470, D. Álvaro de Estúñiga derrotou militarmente seu adversário e tomou o controle da maior parte do Priorado do Hospital em Castela. Juan de Valenzuela continuou controlando uma parte do Priorado. Em 1474, este ainda era o contexto de crise que se instalara no ramo castelhano do Hospital, exatamente quando subiam ao trono os Reis Católicos.

Os Reis Católicos, no início do seu reinado, tiveram que enfrentar uma verdadeira guerra com o rei de Portugal pela sucessão ao trono castelhano (1475-1479). O monarca português tinha o apoio de uma parcela da nobreza de Castela, que defendia os direitos da filha de Henrique IV, D. Joana, que também era sua sobrinha. A principal batalha dessa guerra foi a Batalha de Toro, disputada em 2 de março de 1476, nas proximidades da vila de Toro (atual província espanhola de Zamora).

Com a intenção de fazer uma breve síntese acerca da Batalha de Toro, podemos dizer que após a morte do rei castelhano Henrique IV, ocorrida em 1474, o rei português Afonso V interveio ativamente em Castela, no âmbito do que se chamou de Guerra de Sucessão.

Segundo Rui Ramos (RAMOS, SOUSA, MONTEIRO, 2010, p. 164):

Henrique tinha sido um rei fraco, muito diminuído pela doença, e cujo reinado, entre 1454 e 1474, fora atravessado por fortes conflitos entre 
facções da nobreza e pela abertura de uma crise sucessória que se manifestara mesmo antes da morte do monarca. Em 1468 a irmã de Henrique IV, Isabel - a futura rainha Isabel, a Católica -, estabelecera um pacto com o seu irmão, pelo qual o reconhecia como rei de Castela; mas em troca deste reconhecimento Henrique IV teve de nomear Isabel como sua sucessora no trono. A principal consequência do acordo foi o afastamento da filha de Henrique IV da sucessão na Coroa castelhana. Esta infanta, de nome Joana e apodada de a Beltraneja por dizerem os seus inimigos que não era filha do rei, mas de um seu próximo chamado Beltrán de la Cueva, era sobrinha de D. Afonso V. De facto, a mãe da Beltraneja, D. Joana de Portugal, era irmã do rei português e tinha casado com Henrique IV.

O mesmo autor conclui o raciocínio assim (RAMOS, SOUSA, MONTEIRO, 2010, p. 164):

\begin{abstract}
Afonso $\mathrm{V}$ tomou então partido pela sobrinha. Uma vez que havia enviuvado em 1455, o monarca concebeu o plano de casar com D. Joana e assim juntar as coroas de Portugal e Castela. Como adversários tinha os já casados (1469) Isabel e Fernando de Aragão, os futuros Reis Católicos. A divisão da nobreza castelhana era profunda, repartindo-se os apoios entre Afonso V de Portugal e Isabel. Esta e o seu marido Fernando foram aclamados reis de Castela em 1474 e Afonso V intitulou-se também rei de Castela em 1475. A guerra tornou-se inevitável e a 2 de março de 1476 teve lugar a Batalha de Toro, perto da povoação do mesmo nome, na actual província espanhola de Zamora. Apesar de ter chegado a tomar aquela praça e de contar com o apoio de vários fidalgos castelhanos e, até certo momento, do próprio arcebispo de Toledo, Afonso $\mathrm{V}$ acabou por ver-se obrigado a retirar para Portugal. O resultado da incursão em Castela não foi favorável às pretensões do monarca português.
\end{abstract}

Por trás desta crise também estava o antigo Prior Juan de Valenzuela, que participou ativamente na guerra aliado ao grupo partidário do rei de Portugal. Entretanto, o papel de maior destaque nessa contenda foi o de Pedro de Avendaño ou Mendaña, a quem Valenzuela havia nomeado alcaide do castelo hospitalário de Castronuño. Como alcaide, Pedro conseguiu controlar os senhorios da região e converteu o castelo em um dos principais pontos de resistência ao exército de D. Fernando. No entanto, em 1477, o castelo foi tomado pelas tropas fernandinas e imediatamente demolido. "Luego los Reyes Católicos procedieron a devolver los señorios hospitalarios próximos del valle del Guareña (Castronuño, Fuentelapeña, Vadillo y otros), que habíam estado ocupados por el alcaide, ao prior Álvaro de Estúñiga (BARQUERO GOÑI, 2006, p. 33).

Segundo Carlos Barquero Goñi (2006, pp. 32-33):

En este enfrentamiento armado, el prior Álvaro de Estúñiga combatió en el bando de los Reyes Católicos. No obstante, sabemos que algunas posesiones 
del priorato hospitalario de Castilla escapaban a su control e incluso figuraron en el bando opuesto a los monarcas. Fue el caso, por ejemplo, del importante castillo sanjuanista de Consuegra, que llegó a ser asediado por el propio prior Álvaro de Estúñiga. Sin embargo, finalmente tuvo que esperar a la resolución de un processo judicial acerca de su tenencia por la justicia real en 1478 para conseguir recuperar dicha fortaleza.

Com relação à participação do Prior do Crato na Batalha de Toro, podemos acreditar que D. Vasco de Ataíde esteve pessoalmente nesse confronto, pois temos documentos que nos induzem a essa afirmação ${ }^{173}$. Se esse Prior não tivesse participado da Batalha de Toro, causaria certa estranheza, tendo em vista que o Prior já havia lutado ao lado do exército régio em algumas contendas no Norte da África, como por exemplo, em Arzila e Tânger (1471), consolidando uma aliança quase habitual entre o Priorado e a Coroa no século XV (RIBEIRO, 1800, pp. 78-81).

D. Afonso V parte para a luta armada contra Castela, após o fim do reinado de D. Henrique IV, objetivando "proteger os interesses de Joana", filha deste último. Após da Batalha de Toro, em 12 de junho de 1476, o Prior do Crato D. Vasco de Ataíde fora encarregado de prover e armar o Porto e a armada na qual o monarca seguiria para França, com o intuito de receber apoio militar por parte de Luís XI, contra Castela (COSTA, 2000, p. $220)^{174}$. E é provável que D. Vasco de Ataíde não tenha somente preparado a armada do monarca para a França, como também tenha ido junto com ele se encontrar com Luís XI. Sobre isso, veja o que disse José Anastásio de Figueiredo Ribeiro (1800, p. 94):

... á vista da qual se conclúe outrosim, que se com effeito chegaram a partir com ElRei, e a acompanha-lo a Castella os Comendadores, cujas dispozições ficaram expressas naquele § 43.; com tudo para França apenas hiria talvez o Prior, e por isso appareça tendo Lugar-tenente aquelle Fr. Álvaro Pires, que ainda então estava possuindo separadamente a Comenda de Belvêr, e celebrando Capítulo na Sertãa, com outros, que aliàs ainda não podiam estar no Reino.

Apesar da incumbência de preparar o porto e a armada para D. Afonso V, é bem provável que houve também participação direta do Prior do Crato, antes disso, na Batalha de Toro, em 02 de março de 1476. Veja o que José Anastásio de Figueiredo Ribeiro escreveu a respeito disso (1800, p. 78):

\footnotetext{
173 A.N.T.T., Chancelaria de D. Afonso V, Liv. 30, fl. 177.

${ }^{174}$ Segundo Ribeiro (1800, p. 80): "Encontra-se mais copiada no Livro das Vereações da Camara do Porto, do anno de 1475 e 76, huma Carta Regia dirigida ao mesmo referido Prior do Hospital, D. Vasco de Athaîde, escripta de Miranda em 12 de Junho do anno de 1476, a fim de elle apromptar na Cidade do Porto a Armada, em que o Sr. Rei D. Affonso V. havia de partir, como foi, para França".
} 
Em o princípio do anno de 1475 he já bem constante como na Cidade d'Evora se projectou, e determinou sem remédio, a desgraçada, e infausta empreza de o Sr. Rei D. Affonso V. entrar em Castella, e allî occupar á força d'armas a Coroa daqueles Reinos, por cabeça de sua pertendida $2^{\mathrm{a}}$ mulher a Excellente Senhora D. Joanna: e como para se verificar a mesma Entrada nesse Maio seguinte, mandou logo preparar os Grandes, e Senhores, Prelados, Fidalgos, e Cavalleiros, com toda a outra mais gente, que poude ajuntar-se destes seus Reinos. Nesta ocasião pois não se deixou tambem de figurar, entre os principaes, e certos servidores d'ElRei, o mesmo nosso Prior do Crato, D. Vasco d'Athaîde, seu Compadre, com alguns Comendadores da sua Ordem de Malta. Como se prova claramente pelo Liv. XXX. de D. Affonso V. a f. 177, em que se acha a lembrança, ou registro por ementa de huma Carta de dom Vaasquo datahide Prior do Esprital, do seu Conselho \&c., dada em fórma na sobredita Cidade d'Evora a 8 de Março do mencionado anno de 1475, para que podesse arrendar as rendas de seu Priorado por huun anno.

Se este panorama representou a realidade dos fatos, então estivemos diante de um confronto entre dois ramos da Ordem do Hospital, de um lado hospitalários portugueses aliados do rei de Portugal e de Juan de Valenzuela e de outro lado hospitalários castelhanos, sob a liderança do Prior Álvaro de Estúñiga, aliados dos Reis Católicos. Realidade que mais uma vez demonstraria que mesmo dentro de uma instituição religiosa intercontinental às vezes podia haver conflitos entre ramos ligados a diferentes monarquias, o que de fato já havia ocorrido outras vezes na Península Ibérica ${ }^{175}$.

Diante de tudo isso, afirmamos nossa posição em aceitar que houve, sim, na Batalha de Toro, uma aliança entre o Prior do Crato, D. Vasco de Ataíde, o ex-Prior de Castela, Juan de Valenzuela, e o rei de Portugal, D. Afonso V, unidos militar e politicamente para combaterem as tropas do Prior de Castela em exercício, D. Álvaro de Estúñiga, e os Reis Católicos, D. Fernado e D. Isabel. Mesmo que D. Vasco de Ataíde não tenha comparecido pessoalmente ao campo de batalha, certamente foi representado por Diogo Fernandes de Almeida, o que comprova esta tese.

Segundo o Conde de Campo Bello (1931, p. 81), em 1475, durante a expedição de D. Afonso $\mathrm{V}$ à Castela, "para tentar fazer valer os direitos que pretendia possuir à respectiva corôa, por sua segunda esposa a 'excelente Senhora' D. Joana. O Prior D. Vasco de Athayde e muitos dos Cavaleiros portugueses não deixaram de lá aparecer". Só faltou esse autor informar em sua obra a fonte dessa informação, postura que era comum na historiografia de sua época.

\footnotetext{
${ }^{175}$ Para saber mais sobre os conflitos internos nas ordens militares ibéricas, consultar AYALA MARTÍNEZ, 2007, pp. 510-528.
} 
As ordens militares se identificaram com os objetivos políticos da monarquia. Isso é mais notório a partir do processo de secularização que estas instituições experimentaram desde o final do século XIII. Os freires aos poucos se desacralizaram, passando a se comprometer de maneira mais ativa com a realidade de seu mundo profano, provavelmente sentindo-se mais livres para atuarem sem nenhum condicionamento ideológico. Ou seja, nos séculos XIV e XV, os membros das ordens militares passaram a se posicionar ao lado de seus monarcas para junto dele lutarem contra determinados adversários das coroas, além de se aliarem à determinados ramos nobiliárquicos a fim de aumentarem seu status político.

Sobre isso, Carlos de Ayala Martínez (2007, p. 510) escreveu:

\begin{abstract}
Naturalmente, y como es obvio, estas nuevas actitudes manifiestan la creciente vinculación de los miembros de las milicias con los sectores de extracción social nobiliaria de que se nutren de manera cada vez más excluyente y con los que, en último término, se sienten ideologicamente solidarios. Todo ello facilita la instrumentación regia de las órdenes, su posicionamiento incondicional junto al trono. Pero como ese posicionamento es político, en certo modo desinhibido de imperativos religiosos, no siempre fue concebido en términos de incondionalidad: lás órdenes entraban en el "juego político", y en el tenía cabida el cuestionamiento de la autoridade real. De este modo, los freires protagonizan o simplemente participan en un sinnúmero de confrontaciones internas en las que fluctúan entre las fidelidades que no siempre se identifican con la realeza dominante. En otras palavras, actuarán junto a ella frente a enemigos ocasionales del rey, pero también se sumarán a quienes reclamen concesiones o exijan, incluso mediante la violencia, cambios radicales en el status político.
\end{abstract}

Também é certo que um freire hospitalários de outra família nobre lutou ao lado de D. Afonso V na Batalha de Toro e, anos depois, e em 1492, tornaria-se Prior do Crato. Estamos nos referindo a D. Diogo Fernandes de Almeida, sobre o qual já discorremos anteriormente.

Há na Chronica de El Rei D. Afonso V, de Rui de Pina (1790, Cap. 179), referência à participação de Diogo Fernandes de Almeida na Batalha de Toro, compondo o exército de D. Afonso $\mathrm{V}$, assim como a mesma crônica também atesta a participação deste nobre em várias conquistas de praças africanas, além de sabermos também que ele havia participado na defesa da ilha de Rodes, em $1480^{176}$.

Outra hipótese que temos que considerar é a de que Diogo Fernandes de Almeida, em 1476, podia ainda não ser membro da Ordem do Hospital, pois a documentação nos demonstra que em uma correspondência que escreveu ao Papa Inocêncio VIII, dentre outros assuntos, Diogo de Almeida informou que se tornou membro da milícia durante o pontificado

${ }^{176}$ Outras fontes consultadas que confirmam as afirmações acima: Chronica de El Rei D. João II, de Rui de Pina (1950, cap. 27) e Crónica de D. João II e Miscelânea, de Garcia de Resende (1973, caps. 67 e 81). 
de Sisto VII, ou seja, entre os anos de 1471 e 1484 (ALBUQUERQUE, 1992, p. 163). Contudo, preferimos acreditar que antes de 1480, Diogo Fernandes de Almeida já fosse um membro do Hospital, tendo em vista sua participação no cerco da ilha de Rodes e o fato de ele ter sido eleito ao cargo de Prior, ambos os eventos nesse mesmo ano.

Acerca da viagem de D. Afonso V à França, Rui Ramos escreveu o seguinte (RAMOS, SOUSA, MONTEIRO, 2010, p. 164-165):

\begin{abstract}
Invocando o tratado celebrado com a França no ano anterior, Afonso V viajou então para esse reino por via marítima, procurando recolher o apoio do rei Luís XI à sua causa. Apesar de muito bem recebido e de se ter avistado em Tours com o seu homólogo e potencial aliado, o monarca português não encontrou a resposta que esperava. Na verdade, Luís XI estava ocupado na guerra com o duque de Borgonha, Carlos, o Temerário, recorrendo a este pretexto para não corresponder ao pedido de auxílio de Afonso V. Numa derradeira tentativa de conseguir o apoio de que necessitava para retormar a ofensiva em Castela, o soberano português propôs-se servir de medianeiro para acabar com o conflito enre o rei francês e o duque de Borgonha, que, alías, era filho da infanta D. Isabel de Portugal (1397-1471) - filha de D. João I e irmã do rei D. Duarte - e, portanto, primo de D. Afonso V. Este chegou mesmo a avistar-se com o duque Carlos em Nancy, sem, no entanto, alcançar o seu objectivo de pacificação. Ficou assim definitivamente comprometida a possibilidade de ajuda do rei de França às pretensões ibéricas de D. Afonso V. A longa viagem a França saldou-se, desta forma, por um enorme fracasso diplomático e político, de tal maneira que o rei pensou em seguir para Jerusalém, como peregrino, pelo que chegou a redigir e a enviar para Portugal cartas de abdicação e de transferência do trono para o seu filho, o príncipe D. João, que já assegurara a regência em 1476 e 1477. No entanto, acabaria por afastar esta ideia, retormando o trono no regresso ao reino, no final deste ano. Em 1478 os Reis Católicos assinaram um tratado de amizade com Luís XI de França. Ficava, pois, inviabilizada qualquer hipótese de uma aliança luso-francesa contra Castela. Isso mesmo terá sido compreendido por Afonso $\mathrm{V}$ que, sem poder fazer frente ao inimigo castelhano, acabou por aceitar a celebração de um acordo de paz entre os dois reinos, o Tratado de Alcáçovas, de Setembro de 1479.
\end{abstract}

O resultado da guerra de sucessão ao trono castelhano propiciou a consolidação do controle do priorado da Ordem do Hospital em Castela por Álvaro de Estúñiga, em detrimento de Juan de Valenzuela. Apesar disso, a disputa entre ambos ainda se pronlongou por alguns anos. O que levou a essa continuidade foram as cláusulas do tratado de paz entre Portugal e Espanha, o Tratado de Alcáçovas, de 1479, que previa o perdão e a devolução dos bens aos castelhanos que haviam sido partidários da Coroa Portuguesa durante a guerra. Apesar de os Reis Católicos terem outorgado um perdão geral pouco depois, Juan de Valenzuela só teve seus delitos perdoados em novembro de 1479. Somente no ano seguinte a corte de Fernando e Isabel restituíram a Valenzuela os senhorios hospitalários de Castronuño, Fuentelapeña, La 
Bóveda y Vadillo. Contudo, a restituição foi incompleta, tendo sido necessária a reclamação reiterada de embaixadores portugueses aos Reis Católicos em 1480, 1482 e 1486. Somente após isso, Juan de Valenzuela recebeu os senhorios que conservava antes da guerra de sucessão começar. Apesar de tudo, Valenzuela sempre se considerou Prior de Castela, sendo apoiado por um grupo social, dividindo o Priorado com Álvaro de Estúñiga (BARQUERO GOÑI, 2006, p. 34).

Ao ser consultado sobre o conflito entre os priores de Castela, o Papa delegou a resolução do problema ao então Mestre da Ordem do Hospital, Pedro d'Aubusson, que decidiu definitivamente, em 1488, através de sentença, que Juan de Valenzuela havia sido destituído do Priorado de Castela e que Álvaro de Estúñiga havia sido nomeado prior em seu lugar, canonicamente. Assim, o Priorado do Hospital em Castela ficava definitivamente sob a liderança de uma pessoa da confiança dos Reis Católicos.

Vale lembrar que há tempos a monarquia castelhana era aliada do Convento Central da Ordem do Hospital, no contexto da luta incessante no Mediterrâneo contra o avanço islâmico, principalmente contra as frotas Turcas otomanas. Assim, ao verificar que os Reis Católicos haviam vencido a guerra de sucessão e que adquiriam imenso poder na Península Ibérica, era óbvio que o Grão-Mestre da Ordem do Hospital sabia que devia decidir a questão a favor de um dos aliados de D. Fernando, o que manteria, assim, a aliança entre a Ordem e a monarquia castelhana.

Segundo Barquero Goñi (2006, p. 191):

Los Reyes Católicos mantuvieron vínculos muy estrechos con la ordem del Hospital. Con el maestre de la orden, que estaba establecido en esta época en la isla griega de Rodas, entablaron unas relaciones diplomáticas muy intensas en orden a establecer una alianza dirigida contra los turcos. Por lo que respecta a los hospitalarios establecidos en sus reinos, su política fue más ambigua. Por una parte protegieron sus interesses, pero por otro lado tambiém les sometieron a un control sutil pero muy efectivo, sin llegar a plantarse la necesidad de una hipotética incorporación a la corona.

Este trecho acima de Barquero Goñi nos permite ter interpretações acerca de dois temas distintos. A primeira interpretação diz respeito às relações entre Espanha e a Ordem do Hospital, cujo contexto mais importante foi a aliança naval contra os Turcos. Vale relembrar que o Convento Central da Ordem foi expulso de sua base em Rodes pelo Império Turco em 1523 e que depois disso se iniciou a fase de maior influência española na história da Ordem de São João. Depois da capitulação de Rodes, os hospitalários sediaram seu Convento Central na Ilha de Malta, que em 1530 lhes foi cedida como um feudo pelo imperador Carlos V, 
obrigando a Ordem do Hospital a pagar um valor anual simbólico ao rei da Sicília pelo reconhecimento da soberania (COSTA, 2000, p. 54).

De acordo com Barquero Goñi (2003, p. 223):

Detrás del renovado apoyo de la monarquia española a la Orden de San Juan en los años finales del siglo XV se encuentra la política mediterrânea de los Reyes Católicos. En efecto, frente a la creciente amenaza turca que amenaza sus intereses em Sicilia y Nápoles se revaloriza el papel estratégico como vanguardia de los hospitalarios en Rodas a los ojos de los monarcas.

Já durante o primeiro grande cerco de Rodes, em 1480, os Reis Católicos enviaram uma frota de socorro à ilha. A colaboração naval da Espanha com o Convento Central da Ordem do Hospital no Mediterrâneo contra os Turcos continuou também nos anos seguintes, sendo impulsionada por Fernando e Isabel. Esse contexto é a origem da aliança que uniu as frotas espanholas e hospitalárias durante os séculos XVI e XVII.

Há vários testemunhos acerca da proteção dos Reis Católicos aos interesses da Ordem do Hospital, a citar, testemunhos que atestam que esses monarcas velavam pelo envio correto e frequente de dinheiro ao Mestre e Convento Central de Rodes, protegendo os interesses do tesouro comum do Hospital na Espanha e fazendo com que o tesouro comum do Convento Central continuasse recebendo quantias procedentes das possessões hospitalárias da Península Ibérica (BARQUERO GOÑI, 2003, pp. 223-226).

Consequência desse interesse dos Reis Católicos pelos assuntos do Mediterrâneo Oriental foi a intensificação das relações diplomáticas com o Convento Central. Segundo Barquero Goñi (2006, pp. 226-227):

Es bien significativo que un formulario de correspondencia de los monarcas españoles incluya el encabezamiento con el que debían redactarse las cartas dirigidas al maestre de Rodas. Sabemos que los Reyes Católicos y el maestre del Hospital se intercambian noticias sobre las potencias islâmicas en sus respectivas áreas geográficas de influencia. El dignatario sanjuanista además envía regalos a los monarcas. Hay constancia, incluso, de la presencia de un embajador del maestre de Rodas en 1480 por los reinos de Castilla y Aragón. Un tema frecuente en la correspondencia diplomática de los Reyes Católicos con el maestre de la Orden fue, por supuesto, la defensa de los intereses de sus súbditos en la própria isla de Rodas y en las aguas circundantes. El rey Fernando procura proteger con firmeza a los mercaderes españoles que actúan por la zona.

Comparando todo esse contexto que envolveu Coroa Espanhola e Ordem do Hospital com o contexto da relação entre o Reino de Portugal e o Convento Central da Ordem, 
identificamos elementos em comum, referentes ao final do século XV. Portugal tinha interesse em conter a ameaça turca, a fim de garantir suas possessões na África e até mesmo eliminar definitivamente a presença islâmica na Península Ibérica. Em várias ocasiões tropas de hospitalários foram incorporadas no exército régio lusitano para conquista de praças no Norte da África, como por exemplo, nas conquistas de Arzila e Tânger. Apesar dos problemas e conflitos que envolviam Portugal e Castela há vários séculos, quando se tratava de interesses ligados ao Mar Mediterrâneo logo se verificavam pontos de convergência entre os objetivos dos reis ibéricos, que para tanto prestavam demasiado apoio ao Convento Central sempre que o Grão-Mestre solicitava ou quando o próprio Papa o fazia, recebendo, muitas vezes, auxílio militar recíproco.

A segunda interpretação é sobre o controle que a monarquia castelhana exerceu sobre os hospitalários de Castela. O que ocorreu em Castela foi um processo muito semelhante ao que ocorreu em Portugal. Após o fim da Reconquista em Portugal, os monarcas começaram a impor regras que nortearam a operacionalidade das ordens militares. Em muitas ocasiões, a monarquia tentou usar as ordens militares em benefício próprio (COSTA, 2012, p. 7). Contudo, a Ordem do Hospital, mesmo no século XVI, não passou por um processo de controle semelhante aos das Ordens de Avis, Cristo e Santiago, que foram anexadas à Coroa.

$\mathrm{Na}$ Ordem do Hospital, desde D. Manuel I, o rei interferiu diretamente na escolha do Prior do Crato, o que demonstra que os monarcas também pretendiam controlar o ramo português desta instituição, porém, pelo fato da Ordem possuir um Convento Central distante de Portugal, atuante na guerra contra o Império Otomano e ligado aos interesses da Cúria Romana (o que de certa forma ia ao encontro dos interesses comerciais portugueses) ${ }^{177}$, ao invés da anexação à Coroa, a medida tomada pelos reis foi a escolha dos Priores, pessoas da confiança do rei. A partir do reinado de D. João III, os Priores do Crato são infantes ${ }^{178}$.

D. Manuel solicitou ao Papa a dignidade prioral do Crato para D. João de Meneses, aristocrata da sua confiança, solicitação que foi acatada pelo Papa Júlio II ${ }^{179}$. Já D. João III,

\footnotetext{
${ }^{177}$ No século XVI, os Turcos eram uma ameaça ao comércio marítimo português com a Índia. Sabe-se que em 1514 foi interceptada uma armada Turca que pretendia carregar madeira para galés e navios do Sultão, com o intuito de destruir a armada de Portugal na Índia (A.N.T.T., Corpo Cronológico, Liv. I, m. 11, nº 61).

178 Em 1522, D. João III conseguiu do Papa Adriano VI, pelo breve Exposuit nobis, a autorização para a nomeação de um dos infantes com mais de seis anos para o cargo de Prior do Crato (A.NT.T., Bulas, m. 23, $\mathrm{n}^{\circ}$ 19). No mesmo ano, o mesmo Papa expediu mais um breve informando ao monarca de que não poderia aceder às suas súplicas (A.N.T.T., Bulas, m. 13, $\mathrm{n}^{\circ}$ 12). Contudo, em 1524, o Papa Clemente VII retomou a questão e pediu ao Grão-Mestre dos hospitalários que não se intrometesse no provimento do Priorado de Portugal (A.N.T.T., Bulas, m. 15, no 25 e Gavetas, VI, m. ún., no 294). Em 1528, o infante D. Luís, irmão de D. João III, após atingir a maioridade, assume o cargo de Prior, ao qual renucia em $1551 \mathrm{em}$ favor de seu filho, D. Antônio. 179 A.N.T.T., Corpo Cronológico, Liv. 1, m. 7, nº 66; Bulas, m. 6, nº 48; Gavetas, VI, m. ún., no 33; Núcleo Antigo, $\mathrm{n}^{\circ} 39$, fls. $139 \mathrm{v}-143$.
} 
após a morte de D. João de Meneses, queria que a administração do Priorado fosse confiada a um dos infantes seus irmãos, especificamente a D. Luís ${ }^{180}$, o que consegue após vários anos aguardando e discutindo deliberações papais ${ }^{181}$. Durante a menoridade de D. Luís, o próprio rei foi regente do Priorado (RIBEIRO, 1800). Depois, quando D. Luís demonstrou querer ser sucedido por seu filho D. Antônio, novas negociações com o Papa permitiram a sucessão do Priorado do Crato de acordo com a vontade régia ${ }^{182}$.

Em Portugal e na Espanha esses processos de controle possuíram diversas semelhanças. Sabe-se, por exemplo, que o reinado dos Reis Católicos é o período em que as ordens militares de Calatrava, Santiago e Alcântara são incorporadas na Coroa, assumindo o rei D. Fernando a administração de seus respectivos mestrados. A Ordem do Hospital na Espanha, assim como ocorreu em Portugal, não foi anexada à Coroa porque a monarquia espanhola já controlava a provisão de seus cargos. Na Espanha, a Ordem de Malta só foi incoporada na Coroa em 1802 (BARQUERO GOÑI, 2003, pp. 227-228).

A presença ativa da Igreja, representada pelo seu responsável máximo, foi uma realidade viva entre as ordens militares durante a Idade Média na Península Ibérica. Apesar disso, é preciso ressaltar que é inegável o protagonismo régio no controle dessas instituições, e que estas estavam, em seus objetivos e atividades, basicamente mediadas pelos reis. Nem a legitimação que receberam da Santa Sé, nem a proteção que receberam do Papado, e nem sequer o controle disciplinário que exerceu sobre essas ordens ou sua capacidade para intervir e decidir o âmbito da jurisdição estritamente eclesiástica, privaram os reis de sua capacidade de interferência a respeito dos freires (AYALA MARTÍNEZ, 2007, p. 783).

\footnotetext{
180 A.N.T.T., Corpo Cronológico, Liv. 1, m. 28, no 42.

${ }^{181}$ A.N.T.T., Bulas, m. 13, no 12; m. 15, nº 25; m. 23, nº 19; m. 25, nº 33; Gavetas, VI, m. ún., nº 294.

182 A.N.T.T., Bulas, m. 30, $\mathrm{n}^{\circ} 23$.
} 


\section{CONSIDERAÇÕES}

Buscamos, ao longo desta tese, analisar a bibliografia mais atualizada existente sobre cada tema pesquisado, mas às vezes precisamos recorrer a obras com mais de dois séculos de existência, tendo em vista que da mesma forma que há em Portugal escassez de fontes documentais a respeito da Ordem do Hospital (referente aos séculos XII-XV), também não há bibliografia em número suficiente para nos permitir um maior esclarecimento sobre tudo aquilo que nos propusemos a estudar e escrever.

As fontes documentais utilizadas, quase todas são de chancelarias régias ou crônicas, a citar as de D. Afonso V e D. João II. Procuramos utilizar dois documentos, específícos da Ordem do Hospital, o Livro de Herdamentos do Mosteiro de Leça e a Regra da Ordem de São João de Jerusalém, dos quais fizemos a transcrição paleográfica e anexamos ao final desta tese, como anexo.

Conseguimos contestar algumas "certezas" a respeito da data da instalação dos hospitalários no Condado Portucalense, discordando com a historiografia tradicional em alguns posicionamentos, como por exemplo, na questão do suposto jantar que os hospitalários deviam ao bispo há 18 anos em 1130 (vide Capítulo 3).

Acerca da relação entre Santo Lenho, Batalha do Salado e Ordem de São João, tentamos deixar bastante claro que há uma forte carga simbólica de elementos do Movimento de Cruzada inserida no contexto da Ordem do Hospital em Portugal, tanto é que há essa "recriação" da Terra Santa no Alentejo, a utilização do nome Belver para o castelo militar dos hospitalários em Portugal e a associação da igreja da Flor da Rosa, também uma igrejafortaleza, à toponímia de Rodes e ligada à memória da Batalha do Salado. E ainda vale mencionar o perfil devocional criado na Comenda de Vera Cruz de Marmelar, por causa da relíquia do Santo Lenho.

Sobre o papel da nobreza, demonstramos que o aumento de prestígio e de poder das famílias nobres ligadas aos hospitalários em Portugal, não somente favorecia aos interesses da Ordem do Hospital como um todo, como também da própria monarquia, que se via fortalecida à medida em que a memória coletiva da Batalha do Salado, com seus heróis e providências divinas, se tornava mais real.

Ressaltamos o protagonismo de duas famílias, muito ligadas à Ordem do Hospital e à consolidação de suas presenças em torno de Marmelar e da Flor da Rosa: os de Góis-Farinha e os Pereira. Os primeiros, desde o século XIII ligados à Marmelar, tendo como principal 
nome o do Prior Afonso Peres Farinha. Os segundos, associados ao Santo Lenho em pleno século XIV, principalmente no contexto da Batalha do Salado (1340), tendo como principais nomes o Prior Álvaro Gonçalves Pereira (grande homem da Batalha do Salado, comendador de Flor da Rosa/Crato) e frei Gonçalo Pires Pereira (Grão-Comendador nos cinco Reinos de Espanhã).

Ao frei Afonso Peres Farinha, sepultado em Marmelar, atribuiu-se a busca da relíquia no Ultramar. Ao frei Álvaro Gonçalves Pereira, personalidade de destaque na Batalha do Salado e, posteriormente, sepultado no mosteiro da Flor da Rosa/Crato, atribuiu-se a busca e exibição do Santo Lenho na Batalha do Salado.

A transferência da sede da Ordem do Hospital em Portugal de Leça do Balio, cujo complexo monástico havia sido recém-reformado entre 1306 e 1336, para o Crato se deu primeiro porque a região da Flor da Rosa era região fronteiriça e requisitava maior presença de cavaleiros, segundo porque havia desde D. Sancho II imposição régia para povoamento e defesa do local (era a condição colocada na doação das terras aos hospitalários) e terceiro porque o Prior da Ordem do Hospital, D. Álvaro Gonçalves Pereira, também comendador de Flor da Rosa, havia mandado construir um mosteiro no Crato, edificado entre as décadas de 40 e 50 do século XIV. O mosteiro de Leça, primeira sede conventual dos hospitalários em Portugal, apesar de reconstruído, era estrategicamente limitado por estar situado muito ao Norte. Já a região do Crato, esta já possuía um castelo ocupado pelos freires da Ordem desde 1232 e estava numa região em que se encontrava a nova centralidade dos interesses do reino.

Acerca do protagonista histórico desta pesquisa, D. Vasco de Ataíde, chegamos à seguinte conclusão: a família dos Ataíde se caracterizou pela sua participação duradoura na sociedade de corte portuguesa dos finais da Idade Média. Alguns, como mencionamos anteriormente, ocuparam cargos de condes, conselheiros régios, damas de rainhas e líderes de Ordens Militares. Em uma época de feudalismo, na qual os reis precisam tanto dos nobres quanto os nobres precisam do monarca, esse tipo de aliança régia favorecia o alcance dos objetivos da Coroa, assim como perpetuava determinadas linhagens no estrato superior da nobreza.

Vale ressaltar que o próprio irmão de D. Vasco de Ataíde, D. João de Ataíde, também fora prior do Crato antes dele, de 14 de outubro de 1448 até perto de 14 de março de 1453 
$\left(\right.$ COSTA, 2000, p. 250) ${ }^{183}$. D. Vasco assume o Priorado logo após a morte de D. João de Ataíde, em $1453^{184}$.

Com relação ao vínculo existente entre Monarquia Portuguesa e Priorado do Crato, concluímos que à medida que diminuíam as conquistas peninsulares sobre os muçulmanos, as doações à Ordem também diminuíam, fazendo entrar em crise o modelo de relações criado nos dois primeiros séculos de nossa análise. Aconteceu um processo de "senhorialização" que fez com que os freires começassem a se identificar com os interesses da aristocracia, às vezes em detrimento de sua identificação com a monarquia. Por isso é que houve um rearranjo nas relações dos freires do Hospital com a realeza.

Foi bastante comum nos séculos XIV e XV, os reis ibéricos ratificarem à Ordem do Hospital, de forma sistemática, os privilégios e doações outorgados pelos seus antecessores, mas raramente esses privilégios eram ampliados neste período. Em Portugal, os reis também confirmaram, por várias vezes, os antigos privilégios do Hospital. Em troca, os hospitalários prestaram constantes serviços ao seu monarca, destacando-se os serviços de natureza militar. Os freires da Ordem também prestavam outros serviços para as Coroas, como por exemplo, as mediações diplomáticas, servindo como porta-vozes e até pacificadores da relação dos monarcas com o Papado, relação esta que em vários momentos era bastante conflituosa.

Era comum em Portugal, na décima quarta e décima quinta centúrias, priores e comendadores sanjuanistas ocuparem elevados cargos na administração régia, consolidando cada vez mais o poder monárquico no reino. Essa conjuntura propiciou um crescente intervencionismo das monarquias ibéricas no processo de escolha dos priores peninsulares, como ocorreu, por exemplo, em Portugal e em Castela, desde o século XIV, mas principalmente no seguinte.

Vale observar que não eram apenas as relações entre a Coroa e o Priorado as que são significativas para serem analisadas, mas também as relações entre as pessoas que constituíam essa a casa prioral e sua relação com o próprio prior, ou seja, o prior e sua clientela. Essa malha de relações sociais que tinha como eixo e como intermediário o prior, favoreceu o que já denominamos de processo de senhorialização das ordens militares, iniciado desde o século XIV. O conjunto de clérigos, nobres possuidores de cargos régios ou militares e pessoas sem título de nobreza propiciava o desenvolvimento de tais senhorios.

\footnotetext{
${ }^{183}$ Essa autora faz referência à documentação que diz respeito à essa informação: Monumenta Henricina, vol. IX, doc. 201, pp. 321-326 e doc. 202, pp. 326-331 e A.N.T.T., Chancelaria Afonso V, 1. 3, fl. 27v.

${ }^{184}$ A.N.T.T., Leitura Nova, Guadiana, Liv. 3, fl. 160.
} 
Ao longo da tese ainda analisamos a relação do Prior do Crato, D.Vasco de Ataíde, com o Papado, percebendo que em muitas ocasiões a Santa Sé utilizava o Hospital como um braço armado ao serviço da Cristandade e da própria Igreja Católica Apostólica Romana. Da mesma forma que a Igreja precisava que a Ordem do Hospital seguisse contendo o avanço islâmico no Mar Mediterrâneo, a Ordem também precisava da Igreja, às vezes como instância última de julgamento e às vezes para se proteger das tentativas excessivas de controle monárquico por parte de alguns soberanos.

Também analisamos as formas como o Prior D. Vasco de Ataíde se relacionava com o Convento Central da Ordem do Hospital, na ilha de Rodes, fornecendo ajuda militar a cada vez que Grão-Mestre assim o solicitava, e, em várias ocasiões, comparecendo pessoalmente aos Capítulos Gerais e outras convocatórias. É provável que este prior tenha participado do Capítulo Geral que criou a Língua de Castela e Portugal, separando, em uma outra Língua, os reinos de Aragão, Catalunha e Navarra. Quanto a participação de Vasco de Ataíde no cerco de Rodes, em 1480, não acredimos que ele tenha participado, afinal nessa época ele já possuía idade avançada, além do fato de que a documentação não o menciona nessa batalha.

D. Vasco de Ataíde ainda se esforçara ao máximo para manter com as coroas de D. Afonso V e D. João II, relações de proximidade, a ponto de colocar sempre à disposição da monarquía, o apoio militar dos hospitalários. Assim o fez quando D. Afonso V conquistou Arzila e Tânger e também na sua participação na Batalha do Toro, contexto que demonstra claramente uma cisão entre os ramos português e castelhano da Ordem do Hospital.

Atualmente, a Soberana e Militar Ordem Hospitalária de São João de Jerusalém, de Rodes e de Malta, sediada em Roma, apesar de não ser mais uma ordem militar, continua sendo cristã e é um sujeito de direito internacional com funções soberanas, observador permanente das Nações Unidas, que atua em mais de cento e vinte países, em praticamente todos os continentes, na área da assistência médica e social, prestando ajuda humanitária (MARCHINI NETO; LIMA, 2013, pp. 243-249).

Nos dias atuais, a Ordem de Malta possui um programa de ação que inclui, além de assistência médica e social, auxílio às vítimas de conflitos armados ou de catástrofes naturais, serviços de emergências e de primeiros socorros, assim como auxílio a refugiados e desabrigados, sem distinção de raça, religião ou origem, com atuação em mais de 120 países $^{185}$.

${ }^{185}$ A Ordem de Malta possui, inclusive, representação diplomática no Brasil, cuja sede encontra-se em BrasíliaDF. Além da Embaixada, possui outras três associações em nosso país: a Associação Brasileira do Rio de Janeiro da Ordem de Malta, a Associação de São Paulo e Sul do Brasil da Ordem de Malta e a Associação de Brasília e 
A instituição possui cerca de 13.500 membros, 80.000 voluntários formados e 25.000 empregados, sendo a maioria pessoal médico. A Ordem possui diversas organizações pelo mundo, como por exemplo, Grandes Priorados, associações nacionais, organizações de ajuda e fundações, que são as responsáveis pela execução das suas atividades, tanto nas instituições permanentes (hospitais, centro ambulatoriais e centros da terceira idade) quanto através de seus programas médico-sociais e humanitários ${ }^{186}$.

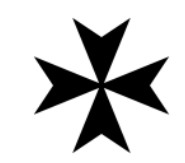

Norte do Brasil da Ordem Malta. Informações retiradas do sitio eletrônico oficial da Ordem de Malta: http://www.orderofmalta.int.

186 Segundo Martim de Albuquerque (1998, p. 15): "Da sediação em Malta adveio à cruz de oito pontas, distintiva dos Cavaleiros e da Ordem, o nome de Cruz de Malta. É ela ainda hoje a base da simbólica estatal da Ordem, como o é, também, do recente Estado de Malta. As oito extremidades da cruz simbolizam as bemaventuranças que se devem viver continuamente, dia-a-dia: 1) manter a alegria espiritual;2) viver honestamente; 3) chorar os nossos pecados; 4) sofrer com humildade as injúrias; 5) amar a justiça; 6) praticar a misericórdia; 7) ser sinceros e limpos de coração; 8) suportar com paciência as perseguições”. 
FONTES E BIBLIOGRAFIA

\section{PRINCIPAIS FONTES DOCUMENTAIS MANUSCRITAS}

\section{Arquivo Distrital de Braga}

Comendas, Távora (Santa Maria de), nº 50, doc. 15.

\section{Arquivo Distrital do Porto}

Livro dos Originais do Cabido

(803), fls. 89-94.

(1675), fl. 18.

(1679), fl. 9.

\section{Arquivo Nacional da Torre do Tombo}

Bulas e Colecção Especial de Bulas

Bulas, cx. 8, m. 27, no $12 ;$ m. 23, no $19 ;$ m. 13, no $12 ;$ m. 15, no $25 ;$ m. 6, no $48 ;$ m. 30, no 23.

Chancelarias Régias

D. Afonso III

Liv. 1, fl. 49.

D. Afonso $V$

Liv. 1 , fls. $15,35 \mathrm{v}, 82$, fl. $128 \mathrm{v}$.

Liv. 4, fls. 33v, 73-74v.

Liv. 3, fl. 61v.

Liv. 8, fls. 50, 188.

Liv. 9, fls. 115, 162v.

Liv. 10, fls. 15, 39v, 50-53, 73, 76, 88v, 118v, 125.

Liv. 11 , fls. $123 \mathrm{v}, 142 \mathrm{v}$.

Liv. 12, fls. 26v, 36, 42v, 67v, 87v.

Liv. 13, fls. $11 \mathrm{v}, 69 \mathrm{v}$.

Liv. 14, fls. 12v, 48v, 85, 107v.

Liv. 15, fls. 11, 12v, 24, 43-43v, 45, 46, 69v, 72, 76, 82v, 136v.

Liv. 16, fl. 37.

Liv. 21, fls. 22, 96v.

Liv. 22, fls. 5, 54, 66-66v, 73, 86, 108, 111v, 112, 127v.

Liv. 23, fls. $59 \mathrm{v}, 187$.

Liv. 24, fls. 92.

Liv. 26, fl. 9.

Liv. 28, fls. 28, 45v, 53, 55, 74, 75, 108, 119v, 123-124v.

Liv. 29, fls. 13-13v, 64v, 250v.

Liv. 30. fls. 3v, 18, 21, 22, 32, 48v, 52, 70v, 122v, 136v, 152, 153, 177, 175v, 177.

Liv. 31, fls. 24.

Liv. 34, fls. 19v, 113. 


\section{Dinis}

Liv. 1, fl. 124.

D. João II

Liv. 8, fl. 160v.

D. Manuel I

Liv. 11, fl. 6.

Cartório do Bailiado de Leça

Colecção Costa Basto, $\mathrm{n}^{\circ}$ 4, Livro dos Herdamentos e Doações do Mosteiro de Leça, fls. 118.

\section{Corpo Cronológico}

Liv. I, m.4, no 74; m.7, no 66; m. 11, nº $61 ;$ m. 28, $n^{\circ} 42$.

Liv. II, m. $7, \mathrm{n}^{\mathrm{o}} 75$.

Cortes

$\mathrm{m} .2, \mathrm{n}^{\mathrm{o}} 2$.

Gavetas

VI, m. ún., no 19, 22, 24, 29, 33, 34, 87, 88, 89, 90, 102, 103, 104, 159, 164, 170, 175, 176, 181, 182, 184, 185, 187, 188, 189, 190, 191, 192, 196, 215, 264, 271, 294.

VII, m. 7, no 23.

$X, \mathrm{~m} .3, \mathrm{n}^{\circ} 6$.

$X I$, m. $7, \mathrm{n}^{\mathrm{o}} 10$.

$X V, \mathrm{~m} .1, \mathrm{n}^{\circ} 65$.

$X X$, m. $6, \mathrm{n}^{\circ} 15$.

Leitura Nova

Além Douro,

Liv. 1, fl. 117v, 123v, 180.

Beira,

Liv. 1, fls. 149-149v.

Liv. 2, fls. 78v-79, 180-182.

Direitos Reais,

Liv. 1 , fls. $85 \mathrm{v}-88 \mathrm{v}$ e sum.

Estremadura,

Liv. 5, fls. 294v-295.

Guadiana,

Liv. 1, fls. 122-127.

Liv. 2, fls. 296.

Liv. 3, fls. 57v-58, 160-161.

Liv. 4, fl. 13v, 108, 109v-110v, 158-158v, 194v-195v, 271v-272.

Liv. 5, fls. $57 \mathrm{v}-58,127 \mathrm{v}, 234 \mathrm{v}$.

Liv. 6, fls. 71-71v, 94-94v, 103-103v.

Legitimações,

Liv. 1, fls. 146, 172, 200v, 227-228, 259-259v, 290.

Liv. 2, fls. 14v-15, 25v-26, 32v, 46, 77, 135.

Liv. 3, fls. 33v, 157-157v, 167-167v, 176v-177, 221v, 241v-242, 269v, 250v-251, 280v, 283284.

Mestrados, 
Liv. 1, fl. 153.

Místicos,

Liv. 3, fls. 282-283, 290v.

Núcleo Antigo

n 39 , fls. 138-145; nº 239, no 459 .

Biblioteca da Ajuda

Regra da Ordem de São João de Jerusalém.

49-II-32, fls. 245-258.

Bibliothèque Nationale de France

Opera Guillelmi Caoursin, Rhodiorum vicecancellarii: Obsidionis Rhodiae Urbis Descriptio. Res. K-89.

\section{PRINCIPAIS FONTES DOCUMENTAIS IMPRESSAS}

ALMEIDA, Manuel Lopes de [et al.]. Monumenta Henricina. Coimbra: 1960.

AYALA MARTÍnEZ, Carlos de. Libro de Privilegios de la Orden de San Juan de Jerusalén en Castilla y León (siglos XII-XV). Madrid: Editorial Complutense, 1995.

AZEVEDO, Rui de. Documentos Medievais Portugueses. Lisboa: Academia Portuguesa de História, 1958. Vol.1.

CAOURSIN, Guillaume. Siege of Rhodes. Tradução de Johan Kaye. London: Alex Murray and Son, 1870. Texto original em Latim, de 1490.

Collecção Geral dos Antigos e Modernos Privilegios Concedidos Successivamente a Sagrada, E Militar Ordem de S. João do Hospital de Jerusalem, e Confirmados pelos Senhores Reis de Portugal athé el-Rei Nosso Senhor D. Miguel I', por alvará de 12 de Novembro de 1830. Lisboa: Regia Typographia Silviana, 1832.

COSTA, Mário Julio de Almeida (Editor). Ordenações Afonsinas. Lisboa: Fundação Calouste Gunbenkian, 1984. 
FONSECA, Luís Adão da (Coord.). A Comenda de Vera Cruz de Marmelar, Corpus Documental (1258-1640). In Militarium Ordinum Analecta. Vol. 16. Porto: Cepese, 2013.

FREIRE, Anselmo Braamcamp. Brasões da Sala de Sintra. Coimbra: Imprensa da Universidade, 1921-1930. 3 vols.

Brasões da Sala de Sintra. Lisboa: Imprensa Nacional Casa da Moeda, 1996. 3

vols.

Os Sessenta Milhões Outorgados em 1478. In Archivo Historico Portuguez. Vol.

IV. Lisboa: 1960.

LE ROULX, Jean Delaville (Ed.). Cartulaire Générale de l'Ordre des Hospitaliers de Saint-Jean de Jérusalem (1100-1310). Paris: Ernest Leroux,1894-1906. 4 Vols.

LEÃO, Duarte Nunes de. Crónica del Rey D. João o I. Lisboa: Officina de Joze de Aquino Bulhoens: 1780.

NEVES, João Alves das (Coordenador). Pedro Álvares Cabral, O Descobridor do Brasil. $2^{\mathrm{a}}$ ed. Porto: Vertente, 1991.

PEDRO, Conde D. Livro de Linhagens (1340). In Portugaliae Monumenta Histórica. Nova Série. Ediçao crítica por José Mattoso. Lisboa: Academia das Ciências, 1980. 2 Volumes.

PINA, Rui de. Chronica de El Rei D. Afonso V. Edição de José Correa da Serra. Lisboa: Officina da Academia Real das Sciências, 1790.

Chronica de El Rei D. João II. Edição de Alberto Martins de Carvalho. Coimbra: Atlântida, 1950.

RESENDE, Garcia de. Crónica de D. João II e Miscelânea. Lisboa: Imprensa NacionalCasa da Moeda, 1973.

RODRIGUES, Miguel Jasmins (Coord.). As Gavetas da Torre do Tombo: edição digital. [CD]. Lisboa: Instituto de Investigação Científica Tropical, 2009. 
SARAIVA, José da Cunha (Publicação). Livro dos Forais, Escrituras, Doações, Privilégios e Inquirições da Ordem de Malta. Lisboa: Arquivo Histórico do Ministério das Finanças, 1948. 3 Vols.

\section{BIBLIOGRAFIA GERAL}

AlbUQUERQUE, Martim de (Dir.). Portugal e a Ordem de Malta: aspectos da Europa. Lisboa: CTT - Correios e Telecomunicações de Portugal, S.A., 1992.

A Ordem de Malta e o Mundo. Lisboa: Edições Inapa, 1998.

AYALA MARTíneZ, Carlos de. Las Órdenes Militares Hispánicas en la Edad Media (Siglos XII-XV). Madrid: Marcial Pons, Ediciones de Historia, 2007.

BANHOZ, Rodrigo Pelais. Concepções de Poder em Afonso II, Rei de Portugal (12111223): fontes jurídicas régia e concelhia. Curitiba: Universidade Federal do Paraná, 2005, p. 62. Dissertação de Mestrado.

BARQUERO GOÑI, Carlos. Los Caballeros Hospitalarios Durante la Edad Media en España (Siglos XII-XV). Burgos: Editorial La Olmeda, 2003.

Los Hospitalarios en La España de los Reyes Católicos (1474 - 1516). Gijón:

Ediciones Trea, 2006.

BELlO, Conde de Campo (D. Henrique). A Soberana Militar Ordem de Malta e a sua Acção em Portugal. Porto: Tipografia Porto Medico, L.da, 1931.

BLOCH, Marc. Apologia da História ou o Ofício de Historiador. Tradução de André Telles. Rio de Janeiro: Jorge Zahar Editor, 2001.

BORCHARDT, Karl; JASPERT, Nikolas; NICHOLSON, Helen (Editores). The Hospitallers, the Mediterranean and Europe. Festschrift for Anthony Luttrell. Hamphire: Ashgate Publishing, 2007.

BURKE, Peter. História e teoria social. Tradução de Klauss Brandini Gerhardt. São Paulo: Editora UNESP, 2002. 
CAPEL, Heloisa Selma Fernandes. Cultura, poder e representações: uma reflexão a partir do ensino de História. Goiânia: UCG, 2006. Disponível em: http://www. sbhe.org.br/novo/congressos/cbhe4/individuais-e-co-autorais-eixo03.htm. Consultado em 05 de março de 2015.

CHARTIER, Roger. História intelectual e história das mentalidades. In. História cultural, entre práticas e representações. Rio de Janeiro: Bertrand, 1990.

COSTA, Américo. Diccionário Chorographico de Portugal Continental e Insular. Porto: Porto Livraria Civilização, 1929.

COSTA, António Carlos Martins. A Batalha de Toro e as relações entre Portugal e Castela: dimensões políticas e militares na segunda metade do século XV. Dissertação de Mestrado em História Medieval apresentada ao Departamento de História da Universidade de Lisboa, em 2011.

COSTA, Avelino de Jesus da. Normas Gerais de Transcrição e Publicação de Documentos e Textos Medievais e Modernos. $3^{\text {a }}$ edição. Coimbra: Faculdade de Letras da Universidade de Coimbra, 1993. [s/ISBN].

COSTA, João Paulo Oliveira e (Coord). Descobridores do Brasil. Exploradores do Atlântico e Construtores do Estado da Índia. Lisboa: Sociedade Histórica da Independência de Portugal, 2000 .

COSTA, Paula Maria de Carvalho Pinto. A Nobreza e Ordem do Hospital: uma aliança estratégica. In FERNANDES, Isabel Cristina Ferreira. As Ordens Militares e as Ordens de Cavalaria na Construção do Mundo Ocidental. Actas do IV Encontro sobre Ordens Militares. Palmela: Câmara Municipal de Palmela, 2005.

A Ordem Militar do Hospital em Portugal: dos finais da Idade Média à Modernidade. Militarium Ordinum Analecta. Vols. 3 e 4. Porto: Fundação Engenheiro António Almeida, 2000.

A Presença dos Hospitalários em Portugal. Gavião: Ramiro Leão, 2010.

Algumas achegas para o estudo dos privilégios da Ordem do Hospital na Idade Média. Actas do II Encontro sobre Ordens Militares. Palmela: Câmara Municipal de Palmela, 1997. Colecção Actas e Colóquios, pp. 311-317. 
As Adaptações das Ordens Militares aos Desafios da "Crise" Tardo-Medieval. Revista da Faculdade de Letras: História. III Série, vol. 5, 2004.

As Ordens Militares: entre a História e a Historiografia. In MARCHINI NETO, Dirceu; NASCIMENTO, Renata Cristina de Sousa (Orgs.). A Idade Média: entre a História e a Historiografia. Goiânia: Editora da PUC Goiás, 2012.

As Visitações: as Ordens Militares portuguesas entre poderes? In FERNANDES, Isabel Cristina Ferreira. As Ordens Militares: Freires, Guerreiros, Cavaleiros. Actas do VI Encontro sobre Ordens Militares. Vol.1. Palmela: Município de Palmela, 2012.

História da Comenda. In FONSECA, Luís Adão da (Coord.) Comendas das Ordens Militares: perfil nacional e inserção internacional. Noudar e Vera Cruz de Marmelar. Militarium Ordinum Analecta. Porto: Cepese/Fronteira do Caos Editores, 2013.

Norma e Desvio na Ordem do Hospital. Revista da Faculdade de Letras. História. Porto, III Série, Vol. 3, 2002.

. O Poder Régio e os Hospitalários na Época de D. Manuel. Actas do III Congresso Histórico de Guimarães - D. Manuel e a sua Época. Vol. II. Guimarães: 2004.

COSTA, Paula Maria de Carvalho Pinto. BARROCA, Mário Jorge. A Doação de Belver à Ordem do Hospital por D. Sancho I: leitura e contextualização do documento de 1194. In FERNANDES, Isabel Cristina Ferreira. As Ordens Militares e as Ordens de Cavalaria entre o Ocidente e o Oriente. Actas do V Encontro sobre Ordens Militares. Palmela: Câmara Municipal de Palmela, 2009.

DEMURGER, Alain. Caballeros de Cristo: Templarios, Hospitalarios, Teutónicos y demás órdenes militares en la Edade Media (siglos XI a XVI). Tradução de Wenceslao Carlos Lozano. Granada: Universidad de Granada, 2005.

Os Templários: uma cavalaria cristã na Idade Média. Tradução de Karina Jannini. Rio de Janeiro: Difel, 2007.

DUBY, Georges. A Sociedade Cavaleiresca. Tradução de Telma Costa. Lisboa: Teorema, 1990.

As Três Ordens ou o Imaginário do Feudalismo. $2^{\mathrm{a}}$ ed. Tradução de Maria Helena Costa Dias. Lisboa: Editorial Estampa, 1994. 
FERNANDES, Fátima Regina. O Poder do Relato na Idade Média Portuguesa: a Batalha do Salado de 1340. In Revista Mosaico. Vol. 4, nº 1, pp. 75-91. Goiânia: 2011.

FONSECA, Luís Adão da (Coord.). As Ordens Militares em Portugal. Seminario Internacional para el estudio de las Órdenes Militares. Madrid, 2002.

FONSECA, Luís Adão da (Dir.). Comendas das Ordens Militares na Idade Média: Actas do Seminário Internacional Sobre Comendas das Ordens Militares. Militarium Ordinum Analecta. Vol. 11. Porto: Fundação Engenheiro António Almeida, 2009.

GARCÍA-GUIJARRO RAMOS, Luis. La Militarización de la Orden del Hospital: líneas para un debate. Actas do III Encontro sobre Ordens Militares. Palmela: Câmara Municipal de Palmela, 1999. Colecção Actas e Colóquios. ISBN 972-772-080-3. Vol.2. pp. 293-302.

Papado, Cruzadas y Órdenes Militares: siglos XI-XIII. Madrid: Cátedra, 1995.

GOMES, Rita Costa. A Corte dos Reis de Portugal no Final da Idade Média. Linda-aVelha: Difel, 1995.

GOMES. Saul António. D. Afonso V: o Africano. Volume 12 de Reis de Portugal. Lisboa: Editor Temas e Debates - Actividades Editoriais, 2009.

Observações em Torno das Chancelarias das Ordens Militares em Portugal na Idade Média. In As Ordens Militares e as Ordens de Cavalaria na Construção do Mundo Ocidental: Actas do IV Encontro Sobre Ordens Militares. Lisboa: Edições Colibri, 2005.

GONZÁLEZ-PAZ, Carlos Andrés. La Orden de San Juan de Jerusalén y las Peregrinaciones en la Galicia Medieval (Siglos XII-XIII). Revista População e Sociedade. Porto: Edições Afrontamento e CEPESE, 2009. ISSN 0873-1861. No 17.

GROUSSET, René. A Epopéia das Cruzadas. Tradução de Luís Serrão. Mem Martins: Publicações Europa-América Lda, 1998.

JOSSERAND, Philippe. Église et Pouvoir dans la Péninsule Ibérique: les orders militaires dans le royaume de Castille (1252-1369). Madrid: Casa de Velázquez, 2004.

JOSSERAND, Philippe. BÉRIOU, Nicole (Orgs). Prier et Combattre: Dictionnaire Européen des Ordres Militaires au Moyen Âge. Paris: Fayard, 2009. 
LE GOFF, Jacques. A Civilização do Ocidente Medieval. $2^{a}$ ed. Tradução de Manuel Ruas. Lisboa: Editorial Estampa, 1995. 2 Vols.

A Idade Média Explicada aos Meus Filhos. Tradução de Hortencia Santos Lencastre. Rio de Janeiro: Agir, 2007.

História e Memória. Trad. Irene Ferreira, Bernardo Leitão e Suzana Ferreira Borges. 5 ed. Campinas: Editora UNICAMP, 2006.

LOMAX, Derek W. Las Órdenes Militares en la Península Ibérica Durante la Edad Media. Salamanca: Instituto de Historia de la Teología Española, 1976.

LUTTRELL, Anthony. The Hospitallers of Rhodes and ther Mediterranean World. Edição Reimpressa. Hamphire: Ashgate Publishing, 2002.

The Making of Christian Malta: from the Early Middle Ages to 1530. Hampshire: Ashgate Publishing, 2002.

MARCHINI NETO, Dirceu. A Ordem do Hospital no Noroeste da Península Ibérica: doações e privilégios (séculos XII-XV). Dissertação de Mestrado em História Medieval e do Renascimento, apresentada à Universidade do Porto em maio de 2010.

MARCHINI NETO, Dirceu; NASCIMENTO, Renata Cristina de Sousa (Orgs.). A Idade Média: entre a História e a Historiografia. Goiânia: Editora da PUC Goiás, 2012.

MARCHINI NETO, Dirceu; LIMA, Débora Rosa de. História, memória e comemoração: os 900 anos da Ordem de Malta. In Revista Brasileira de História das Religiões. $\mathrm{N}^{\mathbf{0}} 17$, setembro de 2013.

MARQUES, A. H. de Oliveira. Nova História de Portugal. Vol. IV. Portugal na Crise dos Séculos XIV e XV. Lisboa: Editorial Presença, 1987.

MARQUES, José. A Assistência no Norte de Portugal nos Finais da Idade Média. Revista da Faculdade de Letras. Universidade do Porto. 2. ${ }^{a}$ Série. Vol. VI. Porto, 1989.

Relações entre Portugal e Castela nos Finais da Idade Média. Braga: Fundação Calouste Gulbenkian, Junta Nacional de Investigação Científica e Tecnológica, 1994. 
MATTOSO, José (Dir.). História de Portugal: a monarquia feudal (1096-1480). Lisboa: Editorial Estampa, 1997.

História de Portugal: no alvorecer da Modernidade (1480-1620). Lisboa: Editorial Estampa, 1997.

MENDONÇA, Manuela. Documentos Relativos às Ordens Militares na Chancelaria de D. Manuel. Tipologia e conteúdos. In FERNANDES, Isabel Cristina Ferreira. Ordens Militares: Guerra, Religião, Poder e Cultura. Actas do III Encontro sobre Ordens Militares. Vol.1. Lisboa: Edições Colibri, 1999.

D. João II: um percurso humano e político nas origens da Modernidade em Portugal. $2^{\mathrm{a}}$ ed. Lisboa: Editorial Estampa, 1991.

MORENO, Humberto Baquero. Vias Portuguesas de Peregrinação a Santiago de Compostela na Idade Média. Revista da Faculdade de Letras: História. II Série, vol. III, 1986, pp. 77 90. ISSN 0871-164X.

NICHOLSON, Helen. The Knights Hospitaller. Woodbridge: The Boydell Press, 2011.

OLIVAL, Fernanda. Norte de África ou Índia? Ordens Militares e serviços (séc. XVI). In FERNANDES, Isabel Cristina Ferreira. As Ordens Militares e as Ordens de Cavalaria na Construção do Mundo Ocidental. Actas do IV Encontro sobre Ordens Militares. Palmela: Câmara Municipal de Palmela, 2005.

Os Áustrias e as Reformas das Ordens Militares Portuguesas. Hispânia. Madrid, LXIV/1, Núm. 216, 2004.

OLIVEIRA, Luís Filipe. A Coroa, os Mestres e os Comendadores: As Ordens Militares de Avis e de Santiago (1330-1449). Faro: Universidade do Algarve, 2008.

RAMOS, Rui (Coord.); SOUSA, Bernardo Vasconcelos e; MONTEIRO, Nuno Gonçalo. História de Portugal. $4^{\text {a }}$ ed. Lisboa: A Esfera dos Livros, 2010.

REIS, José Carlos. História \& Teoria: Historicismo, Modernidade, Temporalidade e Verdade. Rio de Janeiro: FGV, 2006. 
RIBEIRO, José Anastasio de Figueiredo. História da Ordem do Hospital, hoje de Malta, dos Senhores Grão-Priores Della em Portugal: fundada sobre os documentos, que podem supprir, confirmar, ou emendar o pouco, incerto, ou falso, que della se acha impresso: servindo incidentemente a outros muitos assumptos, com geral utilidade. Parte I. Até a morte do Senhor Rei D. Sancho II. Lisboa: Officina de Simão Thaddeo Ferreira, 1793.

Nova História da Militar Ordem de Malta, e dos Senhores Grão-Priores Della, em Portugal: fundada sobre os documentos, que só podem supprir, confirmar, ou emendar o pouco, incerto, ou falso, que della se acha impresso: servindo incidentemente a outros muitos assumptos, com geral utilidade. Parte II. Até a morte do Senhor Rei D. Diniz. Lisboa: Officina de Simão Thaddeo Ferreira, 1800.

Nova História da Militar Ordem de Malta, e dos Senhores Grão-Priores Della, em Portugal: fundada sobre os documentos, que só podem supprir, confirmar, ou emendar o pouco, incerto, ou falso, que della se acha impresso: servindo incidentemente a outros muitos assumptos, com geral utilidade. Parte III. Até os nossos dias; com o copioso Índice geral, de que necessita. Lisboa: Officina de Simão Thaddeo Ferreira, 1800.

RICOEUR, Paul. A Memória, a História, o Esquecimento. Tradução de Alain François [et al.]. Campinas: Editora da Unicamp, 2007.

Tempo e narrativa. Campinas: Papirus, 1994. Vol. 1.

RILEY-SMITH, Jonathan. Hospitallers: the history of the Order of St. John. Londres: The Hambledom Press, 1999.

Templars and Hospitallers as Professed Religious in The Holy Land. Notre Dame: University of Notre Dame Press, 2010.

The Crusades: a short history. Londres: The Athlone Press Limited, 1990.

The Knights Hospitaller in The Levant, c. 1070-1309. Hampshire: Palgrave Macmillan, 2012.

What Were The Crusades? 2a ed. Londres: The Macmillan Press Ltd, 1992.

RUIZ GÓMEZ, Francisco. Las Lenguas en el Gobierno Interno de la Orden del Hospital de San Juan de Jerusalén al Final de la Edad Media. Actas do V Encontro sobre Ordens Militares. Palmela: Câmara Municipal de Palmela, 2009. Colecção Ordens Militares. 
RÜSEN, Jörn. Reconstrução do Passado. Teoria da História II: os princípios da pesquisa histórica. Tradução de Estevão de Rezende Martins. Brasília: Editora Universidade de Brasília, 2010.

SANTA CATHARINA, Fr. Lucas de. Malta Portugueza. Memorias da Nobilíssima e Sagrada Ordem dos Hospitalários de S. João de Jerusalém, especialmente do que pertence à Monarchia Portugueza. Lisboa: Officina de Joseph António da Sylva, 1734.

SÃO PAYO, Luís de Mello Vaz de. O Bailio de Leça Frei Henrique Teles. Filermo. Porto: [s.n.]. [s/ISSN]. (1993).

SERRÃO, Joaquim Veríssimo. História de Portugal: Estado, pátria e nação (1080-1415). Vol. I. $4^{\text {a }}$ ed, rev. Lisboa: Editorial Verbo, 1990.

História de Portugal: Formação do Estado Moderno (1415-1495). Vol. II. Lisboa: Editorial Verbo, 1980.

SILVA, Isabel Luísa Morgado de Sousa e. A Ordem de Cristo: 1417-1521. Militarium Ordinum Analecta. Vol. 6. Porto: Fundação Engenheiro António de Almeida, 2002. ISSN 0874-0003.

Uma Dinâmica Política Concertada: D. Manuel, administrador da Ordem de Cristo e rei de Portugal. As Ordens Militares e as Ordens de Cavalaria na Construção do Mundo Ocidental. Actas do IV Encontro Sobre Ordens Militares. Palmela: Edições Colibri, 2005 .

SILVA, Isabel Luísa Morgado de Sousa e [et al.]. As Ordens Militares no Reinado de D. João I. Militarium Ordinum Analecta. Vol. 1. Porto: Fundação Engenheiro António Almeida, 1997. ISSN 0874-0003.

TYERMAN, Christopher. Las Guerras de Dios: una nueva historia de las cruzadas. Tradução de Cecilia Belza [et al]. Barcelona: Critica, 2007.

VASCONCELOS, António Maria Falcão Pestana de. Nobreza e Ordens Militares: relações sociais e de poder (séculos XIV a XVI). Tese de doutoramento apresentada à Universidade do Porto (Portugal), 2008. 2 Vols. 


\section{ANEXO I \\ TRANSCRIÇÕES PALEOGRÁFICAS}

Conforme já explicado, apresentamos a transcrição parcial de dois documentos, a saber:

1 - Livro dos Herdamentos e Doações do Mosteiro de Leça. Arquivo Nacional da Torre do Tombo, Cartório do Bailiado de Leça, Colecção Costa Basto, Número 4, fólios 1-18.

2 - Regra da Ordem de São João de Jerusalém. Biblioteca da Ajuda, 49-II-32, fólios 245258.

Tenha-se em consideração que na transcrição das duas fontes documentais apresentadas utilizamos as Normas Gerais de Transcrição e Publicação de Documentos e Textos Medievais e Modernos, editadas por Avelino de Jesus da Costa, $3^{\mathrm{a}}$ edição. Coimbra: Faculdade de Letras da Universidade de Coimbra, 1993. 


\section{LIVRO DOS HERDAMENTOS E DOAÇÕES DO MOSTEIRO DE LEÇA ARQUIVO NACIONAL DA TORRE DO TOMBO, CARTÓRIO DO BAILIADO DE LEÇA, COLECÇÃO COSTA BASTO, Nº 4}

Livro dos herdamentos e doações deste mosteiro de Leça e de outras comendas e das liberdades e privilegios dos Reys de Portugal e de Hespanha concedidos a Ordem de São Joam Bautista do Hospital de Jerusalem e tornado a lume e concertado pelo muyto magnifico senhor Gram Canceler Frei Christovão de Cernache Pereira cavaleiro professo da dita Ordem e balyo actual de Leça do concelho de Sua Alteza. Feito na mesma Leça e acabado a XXIV de Fevereiro de MV'LI (1551-61?) ${ }^{1}$.

$(\text { Fólio 1) })^{2}$

Privilegio de Innocencio quarto en que tange tres cousas quem se apoderar per força das cousas do Spital e dos seus homeens ou lhi retever algũas cousas do que lhi for mandado em alguns testamentos ou as dizimas das sas crianças e novos lavrados per sas mãaos ou per sas despessas levar seja escomungado ataa que satifaça.

${ }^{3}$ Item privilegio d'Onorio III $^{\circ}$ papa per que nenhuum prelado nom ponha sentença d'escomunhom nem entredicto nos freyres e clérigos do Espital em que nom ha outoridade. $<$ Ca o papa nom quer que outrem os julgue se nom $\mathrm{el}^{4}$.>

${ }^{5}$ Item privilegio de papa Aleyxandre quarto en que fala que como quer que alguns leyxem algũas herdades ao Espital que eles nem os seus sussessores nom pousem en elas contra voontade dos freyres que en eses logares esteverem nem en outros quaesquer da Ordem salvo se quando essas herdades leyxarem aa Ordem se foy logo posto e ho ham per algũa escriptura.

\footnotetext{
${ }^{1}$ A data foi escrita com letra estranha e gera dúvida. No entanto, sabe-se que não pode ser 1651.

${ }^{2}$ A numeração dos 18 fólios que publicamos foi atribuída por nós de forma sequencial, na medida em que a reprodução da fonte manuscrita com que trabalhamos não nos permite visualizar a numeração original dos fólios. Numa visita que fizemos ao Arquivo Nacional da Torre do Tombo, com o propósito de verificar esta numeração, não nos foi possível consultar a fonte original.

${ }^{3} \mathrm{Na}$ margem esquerda: "II $"$ ".

${ }^{4}$ Esta frase foi acrescentada em letra menor.

${ }^{5} \mathrm{Na}$ margem esquerda: "III"'.
} 
${ }^{6}$ Item privilegio de papa Innocencio terceyro en que diz que de nos nem de nosos homeens das cousas pera nosso comer nem de nosas vistiduras nem de nosos [2 $2^{\mathrm{a}}$ coluna] gaados nem doutras nosas cousas nom tomem portagem nem viagem nem nenhuum custume.

${ }^{7}$ Item privilegio de papa Bonifacio oitavo en que diz que nom demos dizimas das possissoens antes do concelho gaanhadas nem depoys do concelho das que per nos lavrarmos ou per nosas despesas nem d'ortas nem de crianças de nosos gaados.

${ }^{8}$ Item privilegio de papa Innocencio terceyro en que toma o castelo de Belveer em sa guarda e em sa encomenda.

${ }^{9}$ Item privilegio de papa Innocencio III $^{\circ}$ en que tanje cinco cousas. A primeira he quem se apoderar dos beens dos beens ( $\mathrm{sic}$ ) e possissoens do Espital ou dos fruytos d'elas ou dos seus homeens sen lhys fazendo d'elas reverença. A segunda he quem filhar sen dereito os beens que fossen leyxados en testamento aa Ordem. A terceyra he quem posser sentença en nos freyres. A quarta he quem d'eles levar a dizima dos fruytos que ouverem per seus trabalhos ou a dizima das sas crianças que os bispos os escumungem ataa qui lhy satifaçam. A quinta he quem lançar en eles mãaos violentas seja escumungado e nom possa seer asolto se nom pelo papa.

${ }^{10}$ Item privilegio de Innocencio IIII $^{\circ}$ en que fala que os prelados nom demandem juramento da fieldade nem d'obedeença aos capelães que son postos nas casas da Ordem porque son sujeytos ao papa per privilegios e dos outros se tenham contentos de lhys demandar obedeença e mays nom.

${ }^{11}$ Item privilegio de Celestino III $^{\mathrm{o}}$ que das possissoens que per sas mãaos e as sas despessas lavrarem nom deem dizima. Outrossi o que lançar mãaos violentas en freyres seja escomungado e nom possa seer asolto se nom pelo papa.

\section{(Fólio 2)}

\footnotetext{
${ }^{6} \mathrm{Na}$ margem esquerda: "IIII"

${ }^{7} \mathrm{Na}$ margem esquerda: "Vo".

${ }^{8} \mathrm{Na}$ margem esquerda: "VI"

${ }^{9} \mathrm{Na}$ margem esquerda: "VII $"$ ".

${ }^{10} \mathrm{Na}$ margem esquerda: "VIII".

${ }^{11} \mathrm{Na}$ margem esquerda: "IX".
} 
${ }^{12}$ Item privilegio d'Aleyxandre quarto en que fala que os prelados nom demandem mays dos seus dereitos aa Ordem dos que ouverom ata aqui.

${ }^{13}$ Item privilegio de Gregório IX ${ }^{\mathbf{o}}$ en que manda que se os freires do Spital filharem algũas terras aos enemiigos da fé que posam en elas edificar igrejas e estas igrejas nom sejam sujeitas se nom ao papa.

${ }^{14}$ Item privilegio de Celestino III $^{\circ}$ en que tangem IIII $^{\circ}$ (sic) cousas. Quem lançar mãaos violentas nos freires ou se lhis ${ }^{15}$ fezer reverença se apoderar per força das sas cousas ou dos seus homeens ou lhis retever algũas cousas sua voontade ${ }^{16}$ do que lhi alguns en seus testamentos leixarem ou as dizimas das sas crianças e novos lavrados per sas mãaos ou per sas despesas por as tres cousas sejam escumungados ata que satifaçam por lançar mãaos violentas e nom possa seer asolto <se nom pelo papa> e os logares hu os beens do Espital <fosem> reteudos per força os prelados ponham hi interdicto ata que satifaçam.

${ }^{17}$ Item privilegio de Innocencio quarto en que tanje tres cousas. As duas que todo clerigo ou leygo que prender freyre ou o derribar de as besta deve seer escumungado e nom pode seer asolto sem lhi satifazer aa injuria e dano que lhi fezer aii (sic) he quem lança mãaos violentas nos freires seja escomungado e nom possa seer asolto se nom pelo papa.

${ }^{18}$ Item privilegio de Innocencio III $^{\circ}$ en que diz que nom possam nos nem nossos clerigos escomungar e se alguum queixume de nos ouver diga ao ao (sic) papa.

${ }^{19}$ Item privilegio d'Aleixandre quarto en que diz que posto que sejam guaanhadas letras do papa se nom fezer mençon dos privilegios que o Spital ha nom devem de responder os freyres do Spital per eles. Nem pretextu de taes cartas em que nom façam a dicta mençon nom devem seer cytados nem yr a seu juyzo ${ }^{20}$.

\footnotetext{
${ }^{12} \mathrm{Na}$ margem esquerda: " $\mathrm{X}$ ".

${ }^{13}$ Na margem esquerda: "XI".

${ }^{14} \mathrm{Na}$ margem esquerda: "XII" "

${ }^{15} \mathrm{Na}$ margem esquerda: "[contra] sua vontade". As palavras que se seguem no texto, "fezer reverença", estão sopontadas.

${ }^{16}$ Na margem esquerda: "ou todas".

${ }^{17} \mathrm{Na}$ margem esquerda: "XIII".

${ }^{18} \mathrm{Na}$ margem esquerda: "XIIII"

${ }^{19} \mathrm{Na}$ margem esquerda: "XV".

${ }^{20}$ Esta frase foi acrescentada com letra menor.
} 
[2 $2^{\mathrm{a}}$ Coluna]

${ }^{21}$ Item privilegio d'Aleyxandre quarto en que diz que o Spital possa reteer os beens das igrejas en que nom quiserem confirmar os freyres ou os seus clerigos e dar o seu dereito ao prelado e esto se entende nas casas da Ordem en que ha igrejas que nom forom abadadas.

${ }^{22}$ Item privilegio d'Onorio III $^{\mathrm{o}}$ en que manda que ecriebam (sic) os prelados os clerigos ydoneos que lhis a Ordem presentar e posto que estes clerigos nom sejam tan ydoneos come outros que se hy apresentarem que os nom leyxem por ende confirmar nas sas igrejas. Outrossi que nom ponham sentença nos freires nem nos clerigos da Ordem.

${ }^{23}$ Item privilegio d'Aleyxandre IIII $^{\circ}$ en que diz que sentença en nos ou en nosas igrejas ou logares sejam postas contra nosos privilegios ou indulgencias ou graças que nom valham. E confirma todos hos privilegios que hos seus predecessores derom aa dicta [Ordem] ${ }^{24}$.

${ }^{25}$ Item privilegio d'Aleyxandre IIII $^{\mathrm{o}}$ en que antrepeta que a constitiçom do papa Innocencio IIII $^{\circ}$ que he feyto livro no titolo de privilegiis que se co[...]ca vollentes que nom per juiz e os privilegios da Ordem.

${ }^{26}$ Item privilegio de Innocencio quarto en que diz que letras do papa guaanhadas contra a Ordem dos privilegios e fazendo mençon deles e da Ordem os freires nom sejam teudos de responder per eles.

${ }^{27}$ Item privilegio d'Aleyxandre IIII $^{\circ}$ en que diz que nenhuum prelado nom possa poer sentença nos freires nem nos sergentos do Espital ${ }^{28}$, quer eclesiasticos quer segraes sem mandando special do papa e confirma aa dicta hordem hos privilegios dos seus predecesores, e por sentença que en eles ponham que nom leyxem porem de reger sas oras e dar e receber os sacramentos da Sancta Eglesia ${ }^{29}$.

\footnotetext{
${ }^{21} \mathrm{Na}$ margem esquerda: "XVI"

${ }^{22} \mathrm{Na}$ margem esquerda: "XVII".

${ }^{23} \mathrm{Na}$ margem esquerda: "XVIII"

${ }^{24}$ Esta frase foi acrescentada com letra menor e as palavras que a compõem se prolongam pela margem direita.

${ }^{25} \mathrm{Na}$ margem esquerda: "XIX ${ }^{\mathrm{o}}$ ".

${ }^{26} \mathrm{Na}$ margem esquerda: "XX").

${ }^{27} \mathrm{Na}$ margem esquerda: "XXI"'.

${ }^{28}$ A partir daqui e até "predecessores", o texto foi escrito na margem direita.

${ }^{29} \mathrm{O}$ trecho "e dar e receber os sacramentos da Sancta Eglesia" foi escrito em letra menor.
} 
${ }^{30}$ Item privilegio de papa Clemente quinto que confirma aa Ordem todas as liberdades que lhy forom dadas e outorgadas dos outros padre sanctos e dos reis e dos principes.

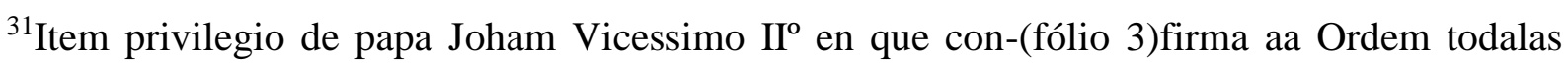
liberdades que lhy forom dadas e outorgadas dos outros padres santos e dos reys e dos principes.

${ }^{32}$ Item privilegio de Gregorio decimo en que diz que o Spital nom ha de pagar dizima ao papa.

${ }^{33}$ Item privilegio de papa Clemente quarto(?) en que diz que o Spital nom ha de pagar dizimas ao papa.

${ }^{34}$ Item privilegio d'Aleyxandre IIII $^{\mathbf{o}}$ en que diz que a Ordem nom de procuraçoens en dereitos aos cardeas nem a nenhuuns meseieiros do papa, salvo se quiserem comer das vindas da Ordem.

${ }^{35}$ Item privilegio de papa Clemente en que manda que nenhuum prelado nom possa poer sentença de scumunhom nos familiayros e sergentes da Ordem nem en aqueles que vam ouvir as oras nas casas do Espital ou hy filham sepulturas nem os que cozem nos seus fornos ou moem nos seus moynhos nem os que hy vam apraz ou vender algũas cousas.

${ }^{36}$ Item privilegio d'Aleyxandre III $^{\circ}$ en que manda aos prelados que todos aqueles que prenderem freyre do Spital ou ho ribarem de sua cavalgadura en suas provincias que os escomunguem ata que lhis satifaça. Outrossi aqueles que meterem mãaos violentas en freires do Spital que os escumunguem e nom possam seer asoltos se nom pelo papa.

\footnotetext{
${ }^{30}$ Na margem esquerda: "XXII"'.

${ }^{31} \mathrm{Na}$ margem esquerda: "XXIII ${ }^{\mathrm{o}}$ ".

${ }^{32} \mathrm{Na}$ margem esquerda: "XXIII" ${ }^{\circ}$. Houve uma repetição da numeração anterior "XXIII", portanto, entendemos ser este registro o "XXIIII"

${ }^{33} \mathrm{Na}$ margem esquerda: "XXV".

${ }^{34} \mathrm{Na}$ margem esquerda: "XXVI"

${ }^{35} \mathrm{Na}$ margem esquerda: "XXVII ${ }^{\circ}$ ".

${ }^{36} \mathrm{Na}$ margem esquerda: "XXVIII"
} 
${ }^{37}$ Item privilegio de Innocencio III $^{\mathbf{o}}$ en que confirma Belveer ao Spital assi como he confirma$\left[2^{\mathrm{a}}\right.$ coluna $]$ do pelos reys.

${ }^{38}$ Item privilegio de Innocencio III $^{\circ}$ en que manda que non sejam enbargadas dos prelados as mandas que alguns fazem ao Spital e os que quiserem filhar sepulturas nas casas da Ordem nom devem devem (sic) a tomar parte os prelados dos cavalos e das armas que leyxam aa Ordem. Outrossi que os clerigos do Spital possam menefestar os que se nas sas igrejas quiserem deitar e que possam ir por eles con cruz e con procisson.

${ }^{39}$ Item privilegio de Innocencio en que diz que nom filhe nenguum na igreja da Ordem homeens ou cousas que se a elas colherem nem outrossi a redor da casas e igrejas.

${ }^{40}$ Item privilegio de Celestino III $^{\circ}$ en que diz que cartas gaanhadas sobre dizimas ou outras cousas quaesquer nom valham se nom fezerem mençom dos freyres do Spital.

${ }^{41}$ Item privilegio de papa Joham XXII ${ }^{\circ}$ en que manda que o Dyam de Coinbra e ho tessoureiro e chantre do Porto alcem força aa Ordem de quem quer que a fezer.

${ }^{42}$ Item privilegio de papa Clemente IIII $^{\mathrm{o}}$ per que confirma ao Spital a doaçom que lhy el rey Dom Afonso fez daquilo que avia no castelo e vila de Miranda do bispado de Coinbra.

${ }^{43}$ Item privilegio de papa Clemente IIII $^{\circ}$ per que confirma ao Spital a doaçom do huso fruyto que lhy el rey fez do castelo e vila de Miranda do bispado de Coinbra.

${ }^{44}$ Item privilegio per que Innocencio terceiro declara e interpeta o concelho geeral en que era conteudo que o papa revogava as doaçoens das dizimas e das igrejas que forom feitas ao Spital pelos leigos no tempo d'agora, tal diz come este manda o papa que se entenda naquelas que forom dadas $\mathrm{X}$ anos ante do concelho.

\footnotetext{
${ }^{37} \mathrm{Na}$ margem esquerda: "XXIX $\mathrm{o}$ ".

${ }^{38} \mathrm{Na}$ margem esquerda: "XXX".

${ }^{39} \mathrm{Na}$ margem esquerda: "XXXI ${ }^{\mathrm{o}}$ ".

${ }^{40} \mathrm{Na}$ margem esquerda: "XXXII

${ }^{41} \mathrm{Na}$ margem esquerda: "XXXIII"

${ }^{42} \mathrm{Na}$ margem esquerda: "XXXIIII"

${ }^{43} \mathrm{Na}$ margem esquerda: "XXXV".

${ }^{44} \mathrm{Na}$ margem esquerda: "XXXVI"
} 
(Fólio 4)

${ }^{45}$ Item privilegio d'Onorio papa terceyro en que manda que se alguns teem possissoens do Spital os quaes foram teer seus padres que estos clerigos paguem ao Spital as rendas que seus padres lhis foram pagar.

Item privilegio d'Onorio papa $\mathrm{III}^{\circ}$ en que e conteudo que el veendo que alguns entendiam mal os privilegios do Spital demandando-lhis dizimas dos barqueiros, madeiras, feo, laa, linho e arvores e fruytos doutras cousas semelhaviis manda que os freyres nom paguem taaes dizimas.

${ }^{46}$ Item privilegio de Celestino papa III $^{\circ}$ en que he conteudo do que alguns arcebispos e bispos e outros prelados davam olio e crisma aas igrejas do Spital e aos clerigos ordeens e consagravam as igrejas e porem diziam estes prelados que o Spital nom podra aver en sas igrejas sen seu outorgamento. Manda o papa que taes escusaçoens vaas come estas nom enbarguem as igrejas do Spital. E manda aos dictos [prela]dos que sen enbargo al[g]un que seja den os dictos sacra[men]tos aas $[\ldots]^{47}$.

${ }^{48}$ Item privilegio de Celestino III $^{\text {o }}$ papa en que manda que os prelados nom enbarguem aqueles que entrar quiserem por freyres na Ordem do Spital que eles possam tomar per sa outoridade por freyres en sa ordem aqueles que quiserem.

${ }^{49}$ Item privilegio de papa Gregorio $\mathrm{X}^{\mathbf{0}}$ en que diz el mandara que as igrejas dessem as dizimas pera socorrimento da Terra Santa e faz graça aos priores do Spital que nom sejam teudos de dar estas dizimas. E nos seus trabalhados de cada dia en serviço da Terra Santa.

${ }^{50}$ Item privilegio de Innocencio papa III $^{\circ}$ en que manda que os prelados nom ponham sentenças d'escumunhom nem de intredicto nos freyres do Spital nem lhis façam agravamentos e se eles receberem alguns agravamentos ou enjurias dos freires o papa lhys dara d'eles comprimento de dereito.

\footnotetext{
${ }^{45}$ Na margem esquerda: "XXXVII".

${ }^{46} \mathrm{Na}$ margem esquerda: "XXXVIII".

${ }^{47}$ A última frase foi acrescentada com letra menor e as palavras que a compõem se prolongam até a margem esquerda.

${ }^{48} \mathrm{Na}$ margem esquerda: "XXXIX".

${ }^{49} \mathrm{Na}$ margem esquerda: "XL".

${ }^{50} \mathrm{Na}$ margem esquerda: "XLI"
} 
${ }^{51}$ Item privilegio d'Onorio papa III $^{\mathrm{o}}$ en que manda que das [ $2^{\mathrm{a}}$ coluna] terras que os freyres da Ordem do Spital guaanharem de amigos nom de las dizimas nem primicias.

${ }^{52}$ Item privilegio de Clemente papa IIII $^{\circ}$ en que manda que aquele meesmo proveyto que a Ordem do Spital avya a aver das letras que forem guaanhadas quando muytos priores eram nos reynos d'Espanha que esse meesmo aja quando for huum nos reynos d'Espanha en que os muitos eram qualquer que for contra esta sua letra ${ }^{53}$.

${ }^{54}$ Item privilegio de Clemente papa II $^{\circ}$ en que confirma os privilegios dos antecessores e outrossi as liberdades e privilegios dados ao Spital pelos reys e principes.

${ }^{55}$ Item privilegio de Bonifacio papa VIII $^{\circ}$ en que confirma os privilegios dos seus predecessores outrossi os privilegios e liberdades dados aos Spital pelos reys e principes.

${ }^{56}$ Item privilegio d'Onorio papa III $^{\circ}$ en que manda que depoys que os freyres do Spital asiinarem convinhavil razom aos vigayros que forem postos nas igrejas que a eles perteecem onde possam manteer sy e pagar os dereitos aos bispos posam filhar as outras cousas en si pera mantimento dos pobres.

${ }^{57}$ Item privilegio de Innocencio papa III $^{\circ}$ en que manda que os prelados nom ajam parte das cousas que alguuns en sa vida ou en sa enfirmidade que freegeses som doutros ou scolherem sepultura mandarem ao Espital pera mantiimento dos pobres. E manda que tam solamente estes prelados ajam a quarta parte das $\langle\text { mandas }\rangle^{58}$ que os $\langle$ seus $\rangle$ freegueses ${ }^{59}$ mandarem aa dicta Ordem en seu testamento, salvo se forem armas ou cavalos de que os prelados nom am d'aver parte nenhũa. E manda que estes prelados nom ajam parte das cousas que alguns en saude dam ao Spital. E manda que se alguns prelados nom quiserem maliciosamente dar confissoens ou comunhom aos seus freegueses que os freire $<\mathrm{s}>$ do (fólio 5) Spital os possam

\footnotetext{
${ }^{51} \mathrm{Na}$ margem esquerda: "XLII"

${ }^{52} \mathrm{Na}$ margem esquerda: "XLIII"

${ }^{53} \mathrm{O}$ trecho "qualquer que for contra esta sua letra" foi escrito com letra menor.

${ }^{54} \mathrm{Na}$ margem esquerda: "XLIIII" ${ }^{\mathrm{o}}$.

${ }^{55} \mathrm{Na}$ margem esquerda: "XLV".

${ }^{56} \mathrm{Na}$ margem esquerda: "XLVIo",

${ }^{57} \mathrm{Na}$ margem esquerda: "XLVII ${ }^{\circ}$ ".

58 A palavra "mortalhas" está riscada.

${ }^{59}$ Segue-se riscado: "do Spital".
} 
<per seus sacadores(?)> asolver dos pecados ascondudos a Deus ${ }^{60}$ e aduz elos soterraz aas sas igrejas contra proceçom $[\ldots]$ o corpo $[\ldots]^{61}$.

${ }^{62}$ Item privilegio de Innocencio papa III $^{\mathrm{o}}$ en que manda que nenhũa pessoa eclesiastica nem outra qualquer nom deffendam os freyres que amdam fora de sa Ordem e som revees nom querendo obedeecer a seus mayores. Item defende que nenhuum nom tome en guarda aver de freyre nenhuum, salvo se for per conselhos dos outros freyres.

${ }^{63}$ Item privilegio de papa Innocencio III $^{\circ}$ en que manda que os freyres nem as igrejas do Spital nom paguem nas talhas dos refazimentos dos muros e das pontes e outras fortalezas.

${ }^{64}$ Item privilegio de Clemente papa IIII $^{\circ}$ per que confirma o padroado da Igreja de Santa Maria de Portel segundo lhe foy dado per Dom Johan davoym.

${ }^{65}$ Item privilegio de Gregorio papa VIII ${ }^{\mathrm{o}}$ en que manda que os arcebispos, bispos e outros prelados digam e defendam aos seus sujeytos que nom filhem peageens portagees nem outras custumagees das cousas que forem pera comer ou pera vistir nem doutras cousas nenhũas que forem pera os freyres do Spital ou pera os seus vasalos. E se o fezerem manda que os prelados ponham en eles sentença d'escumunhom e que nom cantem nem leam nem dem sagramentos nenhuns salvo reendença e bautissmo. Item manda que os clerigos do Spital nom celebrem na (sic) igrejas do Spital que som intredictas por injuria ou mal que alguns en elas fezerem en elas.

${ }^{66}$ Item privilegio de papa Lucio III $^{\circ}$ en que manda que os prelados nom ponham sentença d'escumunhom nos freyres nem en seus homees ${ }^{67}$ nem en sas igrejas contra seus privilegios. Item manda que nom enbargem aqueles que se soterrar quiserem nas igrejas do Spital. Item manda que os prelados nom enbargem os freyres quando apanharem as esmollas e que

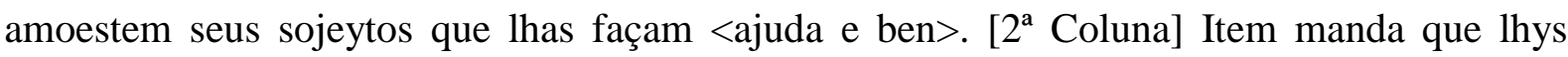
façam aver conprimento de dereito daqueles que lhys mal fezerem.

\footnotetext{
${ }^{60}$ A palavra "Deus" está escrita na margem esquerda.

${ }^{61}$ Palavras escritas na margem esquerda.

${ }^{62} \mathrm{Na}$ margem esquerda: "XLVIII"'.

${ }^{63} \mathrm{Na}$ margem esquerda: "XLIX".

${ }^{64} \mathrm{Na}$ margem esquerda: "L".

${ }^{65} \mathrm{Na}$ margem esquerda: "LI".

${ }^{66} \mathrm{Na}$ margem esquerda: "LII"

${ }^{67} \mathrm{O}$ trecho "nem en seus homees" está escrito na margem esquerda.
} 
${ }^{68}$ Item privilegio de Innocencio papa III $^{\circ}$ en que defende a todos os prelados que nom levem pea de deritos dos homees do Spital que forem achados em adulteryo ou en outros pecados. Item que nom ponham talhas quaes nom devem aas igrejas a clerigos da Ordem.

${ }^{69}$ Item privilegio d'Aleyxandre papa IIII $^{\circ}$ en que manda que o Spital possa apresentar nas igrejas que lhy pertencem freyres ydoneos ou clerigos que comerem no seu refertoyro e dormyrem no seu dormydoyro assynando lhys convinhavil mantiimento <en guisa que ha nom careçam $>{ }^{70}$ e onde possam pagar os dereitos aos bispos e as outras cousas possam aver os freyres pera sa spetelidade e que os arcebispos e bispos e outros prelados nom lhes vaam contra esto.

${ }^{71}$ Item privilegio de Innocencio papa III $^{\circ}$ en que encomenda aos prelados que entendam bem os privilegios da Ordem e como deve e que digam aos sojeytos que façam esmollas aa Ordem e que lhy aguardem o seu dereyto.

${ }^{72}$ Item privilegio de Innocencio papa IIII $^{\circ}$ en que manda aos arcebispos e bispos e outros prelados que se alguuns cometerem como nom devem ou deteverem contra dereyto possissoens, casas que dessem alguns e outras cousas en seus testamentos aos freyres do Spital ou se poserem scentença de scumunhom contra seus privilegios ou lhes deteverem as dizimas das terras que guaanharom antre do concelho jeeral e as lavram a sas mãaos e a sas despessas e das animalyas que criam que estes ataaes se forem leigos que os scumungem a candeas acesas e se forem clerigos ou coonigos regrantes ou monjes que os sospendam dos beneficios ata que satiffaçam e que enviem con sas letras aa Corte de Roma aqueles que som (fólio 6) scomungados porque lançarom mãaos como nom deviam nas pessoas dos freyres.

${ }^{73}$ Item privilegio de Innocencio papa III $^{\circ}$ en que manda aos prelados que nom novas penssoens aas igrejas do Spital nem acrecentem as antigas nem sospendam nem intredigam os clerigos nem as igrejas do Spital e se o fezerem taaes sentenças sejam vãas.

\footnotetext{
${ }^{68} \mathrm{Na}$ margem esquerda: "LIII ${ }^{\mathrm{o}}$ ".

${ }^{69} \mathrm{Na}$ margem esquerda: "LIIII"

${ }^{70} \mathrm{O}$ trecho que se encontra entre parênteses angulosos fora originalmente escrito como anotação marginal (margem direita).

${ }^{71} \mathrm{Na}$ margem esquerda: " $L V^{\mathrm{o}}$ ".

${ }^{72} \mathrm{Na}$ margem esquerda: "LVI ${ }^{\circ}$ ".

${ }^{73} \mathrm{Na}$ margem esquerda: "LVII ${ }^{\circ}$ ".
} 
${ }^{74}$ Item de papa Gregorio VIII ${ }^{\circ}$ en que manda que os freyres do Spital nom paguem dizimas das possissoens barveytos as quaes lavrarem per sas mãaos ou per sas despesas. Outrossy das pescaryas virgeos(?) ortas e camentos(?) de gaados que guaanhasem ante do concelho ou depoys.

${ }^{75}$ Item privilegio de papa Lucio III $^{\circ}$ en que filha so sa guarda e deffendimento os que bem fezerem aa Ordem de Sam Johan e quita lhes a septima parte da peendença dos pecados. Item da (sic) liberdades aaqueles que lhys fazem as esmollas e que as tiram.

${ }^{76}$ Item privilegio de papa Aleyxandre IIII $^{\circ}$ en que manda que os arcebispos e bispos e outros prelados seyam contentos da procuraçom que sooem aver nas igrejas do Spital e que nom demanden outro dereito das dictas igrejas se nom aquel que eles e seus prodecessores sooem aver das dictas igrejas.

${ }^{77}$ Item privilegio de papa Honorio III $^{\mathrm{o}}$ en que manda que os arcebispos e bispos e outros prelados das igrejas se tenham por contentos das procuraçoens que sooem aver das igrejas do Spital eles e seus antecessores e se mays demandarem que os freires lho possam denegar per sa autoridade da Corte de Roma.

${ }^{78}$ Item privilegio de papa Clemente IIII $^{\circ}$ en que manda que os freyres do Spital nom sejam teudos [2a Coluna] de dar procuraçoens aos bispos e prelados, salvo como he conteudo no concelho jeeral.

${ }^{79}$ Item privilegio de papa Johan XXII ${ }^{\circ}$ en que manda ao dayam e chamtre de Lixboa e a meestre scola de Coynbra que se alguns prelados fezerem agravamentos ao Spital que lhys façam d'eles comprimento de dereyto.

\footnotetext{
${ }^{74} \mathrm{Na}$ margem esquerda: "LVIII ${ }^{\mathrm{o}}$ ".

${ }^{75} \mathrm{Na}$ margem esquerda: "LIX ${ }^{\mathrm{o}}$ ".

${ }^{76} \mathrm{Na}$ margem esquerda: "LX"."

${ }^{77} \mathrm{Na}$ margem esquerda: "LXI ${ }^{\mathbf{0}}$ ".

${ }^{78} \mathrm{Na}$ margem esquerda: "LXII"

${ }^{79} \mathrm{Na}$ margem esquerda: "LXIII"
} 
${ }^{80}$ Item privilegio de papa Benedito XII ${ }^{\mathrm{o}}$ en que confirma todolos privilegios e liberdades de seus antecessores. Outrosi confirma todolos privilegios e liberdades outorgadas ao Spital pelos reys e principes.

${ }^{81}$ Item privilegio que os bispos e prelados nom pousem nas sas casas contra sa voontade, salvo se o am de fondamento d'elas.

${ }^{82}$ Outrosi privilegio de papa Celestino en que outorga aos freyres que nom paguem dizimas dos novos que ouverem das terras que lavrarem a sas despesas e que possam fazer igrejas e cimiterios e que possam ouvir e celebrar os officyos da Santa Igreja en no tempo do anterdicto, removendo os escomungados e o anterdicto.

${ }^{83}$ Item privilegio de papa Clemente en que confirma os privilegios e exençoes.

${ }^{84}$ Carta d'el rey Dom Sancho en que confirma aa Ordem do Spital todalas liberdades e doaçoens e exepçoens que lhy forom outorgadas e confirmadas per el rey Dom Afonso seu padre.

${ }^{85}$ Item carta de graça que el rey Dom Denis manda (fólio 7) que nom entre meyrinho nem saiom na (sic) herdades e logares do Spital.

${ }^{86}$ Item carta per que el rey Dom Afonso filho do conde Dom Anrrique couta e confirma todalas herdades e possissoens do Spital. Outrossi manda que os homeens do Spital seyam escusados do tributo e toda servidoem e das portageens. Item couta e confirma o couto de Leça com seus termhos.

${ }^{87}$ Item carta d'el rey Dom Denis per que confirma a conposiçom antre o Spital e Gil Martinz filho de Dona Moor Afonso sobre demanda que era antre o dicto Gil Martinz e o Spital per

\footnotetext{
${ }^{80}$ Na margem esquerda: "LXIIII"'.

${ }^{81} \mathrm{Na}$ margem esquerda: "LXV".

${ }^{82} \mathrm{Na}$ margem esquerda: "LXVI"'.

${ }^{83} \mathrm{Na}$ margem esquerda: "LXVII"”.

${ }^{84} \mathrm{Na}$ margem esquerda: "Io". A partir daqui inicia-se uma nova parte do documento, relacionada aos privilégios régios. $\mathrm{O}$ escriba iniciou este registro com uma letra capital ornamentada.

${ }^{85} \mathrm{Na}$ margem esquerda: "II ${ }^{\circ}$ ".

${ }^{86} \mathrm{Na}$ margem esquerda: "III'".

${ }^{87} \mathrm{Na}$ margem esquerda: "IIII'",
} 
razom dos beens que forom da condessa Dona Leonor e quitousse o dicto Gil Martinz de todolos beens ao Spital e que ouvese en sa vida C L ${ }^{\text {a }}$ libras pelos beens do Spital.

${ }^{88}$ Item carta d'el rey Dom Denis en que confirma o escanbho que foy feito antre o Spital e o conde Dom Pero e sa molher Dona Branca da qual ficou ao Spital o que os suso dictos aviam en Montouto e en seu termho.

${ }^{89}$ Item carta d'el rey Dom Denis en que manda que nenhuum ricomem (sic) nem cavaleyro nem scudeiro nom pousem nas herdades do Spital nem en sas aldeas nem en sas casas nem lhys façam mal nem lhys pam nem vinho nem carne nem criança(?).

${ }^{90}$ Item carta de d'el rey Dom Denis per que mandou que as apelaçoens das [...] fossem primeiramente ao Priol.

${ }^{91}$ Item carta per que el rey Dom Affonso manda que os vasalos da Ordem nom vaam a anudva pera fazer os castelos.

${ }^{92}$ Item carta en como el rey Dom Denis nom ha por foro o serviço que lhy fezerem os vasalos da Ordem na vide(?).

[2 $2^{\mathrm{a}}$ Coluna]

${ }^{93}$ Item carta d'el rey Dom Denis en que manda que os demandadores das esmollas do Spital andem seguros pelas sa terra e nom lhys faça nenguum mal.

${ }^{94}$ Item carta per que el rey Dom Afonso mandou que nom pagasem aduas daquy adeante se pela guissa que aqui he conteudo, convem a saber que os que moram nas herdades alheas e os jugeyros nom vaam aadua. Item manda que el nem seus suscessores nom levem dereitos per razom da adua. Item manda que os homeens estranhos ou sojetos nom paguem na adua. Item manda que clerigos nem homeens fidalgos nom paguem na adua.

\footnotetext{
${ }^{88} \mathrm{Na}$ margem esquerda: "Vo".

${ }^{89} \mathrm{Na}$ margem esquerda: "VI"

${ }^{90} \mathrm{Na}$ margem esquerda: "VII ${ }^{\circ}$ ".

${ }^{91}$ Na margem esquerda: "VIII

${ }^{92} \mathrm{Na}$ margem esquerda: "IX".

${ }^{93} \mathrm{Na}$ margem esquerda: " $\mathrm{X}{ }^{\circ}$ ".

${ }^{94} \mathrm{Na}$ margem esquerda: "XI"
} 
${ }^{95}$ Item carta d'el rey Dom Affonso en que outorga e confirma todolos privilegios graças e liberdades e benfeytoryas que os reys dante'el fezerom ao Spital.

${ }^{96}$ Item carta en que coutou Dom Affonso Enperador d'Espanha todalas herdades que o Spital ha dos reys e doutras pessoas quaesquer.

${ }^{97}$ Item carta en que coutou que nom emprestem aos freyres do Spital.

${ }^{98}$ Item carta d'el rey Dom Denis per que manda que as apelaçoens das terras da Ordem vaam ao Priol $^{99}$.

${ }^{100}$ Item carta d'el rey Dom Affonso en que manda que nenhuum nom pouse nas casas do Spital nem en sas herdades. E manda que guardem os privilegios que a Ordem ha dos outros reys.

${ }^{101}$ Item duas cartas en que el rey Dom Affonso manda a todalas justiças que torne o Espital a sa posse de tolos (sic) logares que forom devassos per el ${ }^{102}$.

${ }^{103}$ Item hũa carta d'el rey Dom Affonso en que manda que os corregedores nom entrem nas terras da Ordem ${ }^{104}$. Item huum estormento de trelado da carta (fólio 8) ${ }^{105}$ d'el rey Dom Affonso padre d'el rey Dom Denis en que manda que os vasalos da Ordem nom paguem adua $^{106}$.

\footnotetext{
${ }^{95} \mathrm{Na}$ margem esquerda: "XII"

${ }^{96} \mathrm{Na}$ margem esquerda: "XIII"

${ }^{97} \mathrm{Na}$ margem esquerda: "XIIII"

${ }^{98} \mathrm{Na}$ margem esquerda: "XV".

${ }^{99}$ Nas margens direita e esquerda existem anotações, com letras muito reduzidas e ilegíveis.

${ }^{100} \mathrm{Na}$ margem esquerda: "XVI".

${ }^{101}$ Na margem esquerda: "XVII ",

${ }^{102} \mathrm{Na}$ margem esquerda desta frase existe uma anotação com letra muito reduzida e ilegível.

${ }^{103} \mathrm{Na}$ margem esquerda: "XVIII"

${ }^{104} \mathrm{Na}$ margem esquerda existe uma anotação, escrita com letra menor, a qual é um resumo desta frase.

${ }^{105}$ Esta frase foi escrita na mesma linha da frase anterior, porém na margem esquerda aparece uma nova numeração: "XIX".

${ }^{106}$ No início deste fólio ( $1^{\mathrm{a}}$ coluna) o escrivão do documento acrescentou algumas numerações e escreveu, com letras pequenas, no alto da folha, os registros $\mathrm{XXII}^{\circ}$ (ilegível), $\mathrm{XXIII}^{\circ}, \mathrm{XXIIII}^{\circ}$ e XXV. Esses acréscimos transcrevem-se assim:

"XXII $[$ [...] filho do conde Dom Anrrique. Tem seelo de cera pendente.

XXIII Item carta d'el rey Dom Affonso de como as justiças nom devem tirar os homeens que se acolherem aas igrejas da Ordem.
} 
${ }^{107}$ Item carta en como se el rey Dom Affonso partio da demanda que fazya ao Spital das vilas e dos castelos e das juridiçoens conteudas na carta.

${ }^{108}$ Item hũa carta que o priol guaanhou d'el rey per que guissa se entende a carta d'el rey Dom Denis da podestade.

${ }^{109}$ Doaçom que fez el rey Dom Sancho aa Ordem do Spital do Castelo de Belveer com sas divisoens e termhos que son conteudos na carta que sobre esto deu ao Spital.

${ }^{110}$ Item carta d'el rey Dom Sancho per que deu o Crato con seus termhos ao Spital.

${ }^{111}$ Item doaçom que fez el rey Dom Sancho ao Spital do Castelo d'Algoso e de seu termho.

${ }^{112}$ Item carta como se el rey Dom Denis quitou da demanda que fazia ao Spital do castelo d'Ulgoso e das aldeas e herdades que som conteudos en esta carta.

${ }^{113}$ Item en como el rey Dom Sancho e seu filho rey Dom Affonso fezerom doaçom ao Spital de Ponteval com todos seus termhos e perteenças.

${ }^{114}$ Item carta en como el rey Dom Affonso deu ao Spital a terça parte da sa herdade de Miran$\left[2^{a}\right.$ Coluna]da contra os castelos de Penas Runhas e do Mogadoyro ${ }^{115}$.

XXIIII Item carta d'el rey Dom Afonso de como devem entregar os freires que as justiças prenderem ao priol ou aos comendadores.

$X X V^{o}$ Item carta d'el rey Dom Affonso per como nom deve entrar moordomo nem sayam nas herdades do Spital nem levar vozes nem coymhas [...]. Esta carta he per que se guarde a outra carta de potestade que fala desto meesmo conto(?) de XXI."

${ }^{107} \mathrm{Na}$ margem esquerda: "XX".

108 Na margem esquerda: "XXI",.

109 Na margem esquerda: "Io". Dado que começa novo conjunto de registro, este inicia-se com letra capital ornamentada.

${ }^{110} \mathrm{Na}$ margem esquerda: "II $\mathrm{I}^{\circ}$.

${ }^{111} \mathrm{Na}$ margem esquerda: "III"'.

${ }^{112} \mathrm{Na}$ margem esquerda: "IV"'.

${ }^{113} \mathrm{Na}$ margem esquerda: "Vo".

${ }^{114} \mathrm{Na}$ margem esquerda: "VI"

115 No início da $2^{\mathrm{a}}$ coluna deste fólio, o escrivão (ou outra pessoa posteriormente) escreveu, com letras pequenas na parte de cima, algumas anotações em forma de registros, com a seguinte numeração: "XXVII" (provavelmente continuando a contagem anterior, que acabava no item "XXV"), "VIII", "IX" e "X". Observação: é provável que houvesse um registro "XXVI" acima do "XXVII", porém a documentação não nos permite assim afirmar. Esses acréscimos transcrevem-se assim:

"XXVII Carta en que os omes moradores nas erdades da Orden seiam escusados de servir e vellar e guardar. 
${ }^{116}$ Item carta per que el rey Dom Affonso deu Fonteelo a Dom Lourenço Soarez.

${ }^{117}$ Item carta per que el rey Dom Affonso deu Foroços a Dom Pero Annes e a sa molher Orraca Paaez.

${ }^{118}$ Item carta d'el rey Dom Denis en que fala do escanbho que o Spital fez com el rey das herdades que avia en Seemires e en Vilalva e en na Veiga de Cabril que lhy deu polo que el rey avya en na Aldeia de Baças e en na Aldeia de Avreiro e en na aldeia da Garganta termho de Poyares.

${ }^{119}$ Item carta en como el rey de Castela deu aa Ordem do Spital as igrejas que som en Mura (sic) e en Serpa e en Mourom e en seus termhos.

${ }^{120}$ Item carta en como rey Dom Affonso deu ao Spital a vila e o castelo de Marvam com todos os dereitos que hy avya.

${ }^{121}$ Item carta en como rey Dom Affonso deu a Alcobaça a terça parte da herdade de Miranda que he com o castelo d'Ulgoso.

${ }^{122}$ Item carta d'escanbho que fez o Espital com o moesteiro d'Alcobaça do qual ficou ao Spital a terça parte da herdade que el rey deu ao dicto meesteiro en Miranda.

${ }^{123}$ Item carta en como el rey Dom Denis da por quite ho priol do Spital de V ${ }^{\mathrm{a}}$ mil libras que lhe enprestara.

VIII Carta en que seyam escusados de talhas e d'aduas.

IX Carta que nom paguem nas talhas que lançam pera os juizes que el rey pom en nos logares.

$X$ Privilegio como el rey Dom Pedro deu de novo [...] ho privelegio que foy dado aa Orden por el rei Dom Afonso."

${ }^{116} \mathrm{Na}$ margem esquerda: "VII ${ }^{\mathrm{o}}$ ".

${ }^{117} \mathrm{Na}$ margem esquerda: "VIII"

${ }^{118} \mathrm{Na}$ margem esquerda: "IX"

${ }^{119}$ Na margem esquerda: " $\mathrm{X}$ ".

${ }^{120} \mathrm{Na}$ margem esquerda: "XI"'.

${ }^{121} \mathrm{Na}$ margem esquerda: "XII ${ }^{\circ}$ ".

${ }^{122} \mathrm{Na}$ margem esquerda: "XIII ${ }^{\mathrm{O}}$ ".

${ }^{123} \mathrm{Na}$ margem esquerda: "XIIII" ${ }^{\circ}$ ". 
${ }^{124}$ Item carta en como el rey Dom Denis da por quyte o priol do Spital de VI mil VIc libras que lhe enprestara.

${ }^{125}$ Item doaçom que fez el rey a Migueel Meendiz e a sa molher d'erdade que e en Vila Pouca hu dizem a Eixara.

(Fólio 9)

${ }^{126}$ Item trelado da carta per que el rey Dom Afonso deu ao Spital a terça parte da sa herdade de Miranda que he contra os castelos de Pena Royas e do Mogadoyro.

${ }^{127}$ Carta per que Dom Joham d'Avoim deu ao Marmelal con seus termhos ao Spital. Tres seelos.

${ }^{128}$ Item item (sic) outra carta per que este Dom Joham d'Avoym deu ao Spital todalas herdades que avia en termho de Beja no logo que chamam a Corte de Pero Moozinho. Dous seelos.

${ }^{129}$ Item outra carta per que o bispo e cabiidoo d'Evora outorgou a doaçom dos termhos que deu Dom Joham d'Avoym ao moesteyro do Marmelal. Dous seelos.

${ }^{130}$ Item outra carta per que Dona Marinha Affonso molher molher (sic) de Dom Joham d'Avoym outorgou a doaçom que fez Dom Joham d'Avoym e seu filho Per'Eannes ao Spital. Huum seelo.

${ }^{131}$ Item outra carta per que o concelho de Portel outorgou a doaçom que Dom Joham d'Avoym fez do moesteyro do Marmelal ao Spital. Huum seelo.

${ }^{132}$ Item outra carta per que Dom Joham d'Avoym fez doaçom do que avia en Beja ao Spital. Tres seelos.

\footnotetext{
${ }^{124} \mathrm{Na}$ margem esquerda: "XV".

${ }^{125} \mathrm{Na}$ margem esquerda: "XVI"

${ }^{126} \mathrm{Na}$ margem esquerda: "XVII"

${ }^{127} \mathrm{Na}$ margem esquerda: "I" ". A letra inicial deste novo conjunto de registros é maiúscula e ornamentada.

${ }^{128}$ Na margem esquerda: "II

${ }^{129}$ Na margem esquerda: "III".

${ }^{130} \mathrm{Na}$ margem esquerda: "IIII".

${ }^{131} \mathrm{Na}$ margem esquerda: " $\mathrm{V}$ ".
} 
${ }^{133}$ Item outra carta per que o bispo e cabiidoo d'Evora enviavam pidir por mercee ao papa que lhys con-[2 $2^{\mathrm{a}}$ Coluna]firmasse a conposiçom que avya antre eles e Dom Joham d'Avoym per razon da igreja de Portel. Dous seelos.

${ }^{134}$ Item huum trelado con dous seelos de todas estas cartas suso scriptas que perteecem aa Baylia do Marmelal.

${ }^{135}$ Item carta en como a condessa Dona Tareiga Affonso molher do conde Dom Anrrique deu ao moesteyro de Leça ao Spital.

${ }^{136}$ Item outra carta de como o Spital deu Fonte Arcada a Fernam Sachez polo padroado da igreja desse logo e por herdades e terra de Lamego e en terra de Panoyas que valesem $\mathrm{CL}^{\mathrm{a}}$ libras en cada huum ano.

${ }^{137}$ Item Stormento en como Fernam Sanchez e sa molher Dona Fruylhy aviam de teer Font'Arcada e o Santo Andre en sa vida e a sa morte ficarem ao Spital desenbargadas e o dicto Fernam Sanchez e sa molher lhy leyxarem herdade que valesse cada ano $\mathrm{L}^{\mathrm{a}}$ libras.

${ }^{138}$ Item prazo d'erdades de que Dom Joham Simoez tiinha do Spital en sa vida e aviam de ficar a sa morte ao Spital com o que o dicto Joham Simoez avia na Azia(?).

${ }^{139}$ Item en como o concelho d'Avrantes deu ao dicto Gil Martinz a herdade Ryo Torto termho d'Avrantes.

${ }^{140}$ Item en como Dom Gil Martinz deu ao Spital a herdade de Ryo Torto que jaz en termho d'Avrantes.

${ }^{132} \mathrm{Na}$ margem esquerda: "VI".

${ }^{133} \mathrm{Na}$ margem esquerda: "VII".

${ }^{134} \mathrm{Na}$ margem esquerda: "VIII".

${ }^{135} \mathrm{Na}$ margem esquerda: "XI".' Faltam os registros "IX" e "X"; não existem no documento.

${ }^{136}$ Na margem esquerda: "XII".

${ }^{137}$ Na margem esquerda: "XIII"".

${ }^{138}$ Na margem esquerda: "XIIII"

${ }^{139} \mathrm{Na}$ margem esquerda: "XV".

${ }^{140} \mathrm{Na}$ margem esquerda: "XVI". 
${ }^{141}$ Item Doaçom que fez Joham Egom e sa molher con seus filhos e con seus irmãaos ao Spital da meiatade da egreja do Teixoso(?) de Covilhaa.

${ }^{142}$ Item en como Gil Vaasquez de Reesendi renuçou ( sic) o dereito que avia na Quintaa de Ferreyros e meteu en posse ho Spital.

(Fólio 10)

${ }^{143}$ Item conposiçom que fez o cabidoo e o bispo d'Evora com Dom Joham d'Avoym per razom dos dereitos que a igreja d'Evora avia d'aver das igrejas do Marmelal. Outrosi como devem a Ordem apresentar os clerigos en elas e o bispo os confirmar.

${ }^{144}$ Item conposiçom que foi feyta antre o bispo e o cabidoo d'Evora e Dom Joham d'Avoym per razom dos dereitos que deve aver da igreja de Sanhoane de Portel Mafomede.

${ }^{145}$ Item conposiçom antre o Spital e a Ordem do Tempre per razom d'erdades e aldeas que som en termho de Miranda e en Trancoso.

${ }^{146}$ Item carta de conposiçom que fez Dom Duran bispo d'Evora e o cabidoo dese logo com Dom Affonso Farinha en que prometerom tambem o bispo e cabidoo do dicto logo come Dom Affomso a guardar todalas cousas que en nos privilegios e cartas de Dom Joham d'Avoym son conteudas.

${ }^{147}$ Item conposiçom que fez a Ordem con o bispo da Guarda sobre a igreja da Sartaae e da Cortiçada e de Belveer e da Amendoa en como a ha d'aver cousa terça en cada hũa d'elas por colheytas e polos outros dereitos epyscopaaes.

${ }^{148}$ Item trelado da conposiçom que o Spital fez com o bispo de Lamego sobrelas igrejas que a Ordem ha em esse bispado.

\footnotetext{
${ }^{141} \mathrm{Na}$ margem esquerda: "XVII ${ }^{\circ}$ ".

${ }^{142} \mathrm{Na}$ margem esquerda: "XVIII ${ }^{\mathrm{o}}$ ".

${ }^{143} \mathrm{Na}$ margem esquerda: "I ${ }^{\circ}$. A letra inicial deste novo conjunto de registros é maiúscula e ornamentada.

${ }^{144} \mathrm{Na}$ margem esquerda: "II $"$ ".

${ }^{145} \mathrm{Na}$ margem esquerda: "III"

${ }^{146}$ Na margem esquerda: "IIII" ".

${ }^{147} \mathrm{Na}$ margem esquerda: "Vo".
} 
${ }^{149}$ Item carta per que o arcebispo Dom Johanne outorgou ao Spital os fruitos da igreja d'Ulgoso.

${ }^{150}$ Item carta de conposiçom que he antre a See de Braga e ho Spital dos dereitos que devem aver das igrejas que se edificarom en terra de Miranda des ha Era de mil e $\mathrm{CC}^{\mathrm{a}}$ e $\mathrm{LXX}^{\mathrm{a}} \mathrm{V}$ anos e edifficarem adeante.

${ }^{151}$ Item conposiçom antre o arcebispo de Bragaa e o Spital en que e conteudo que dereitos deve aver o dicto arcebispo das igrejas do Spital.

\section{[2a Coluna]}

${ }^{152}$ Item conposiçom antre o arcebispo de Bragaa e o Spital en que e conteudo que dereitos e juridiçoens ha d'aver o arcebispo d'algũas igrejas do Spital que aqui son conteudas.

${ }^{153}$ Item conposiçom antre o Spital e o bispo d'Evora sobrela igreja de Portel.

${ }^{154}$ Item conposiçom antre a Ordem do Spital de San Jhoam e o bispo d'Evora per razom dũa procuraçom que a d'aver no couto e que juridiçom ha o bispo nas igrejas e nos logares da Ordem. Outrosi que poder ha nas pessoas dos confreyres e das sas cousas.

${ }^{155}$ Item conposiçom antre o arcebispo de Bragaa e o Spital en que he conteudo que dereitos deve aver o arcebispo na igreja de Poyares.

${ }^{156}$ Item conposiçom antre o bispo da Guarda e o Spital na qual he conteudo os dereitos e juridiçoens que a d'aver o dicto bispo das igrejas que Spital ha no seu bispado as quaes aqui son conteudas.

${ }^{148}$ Na margem esquerda: "VIo".

${ }^{149} \mathrm{Na}$ margem esquerda: "VII ${ }^{\circ}$ ".

${ }^{150} \mathrm{Na}$ margem esquerda: "VIII".

${ }^{151} \mathrm{Na}$ margem esquerda: "IX"

152 Na margem esquerda: " $\mathrm{X}$ ".

${ }^{153} \mathrm{Na}$ margem esquerda: "XI".

${ }^{154} \mathrm{Na}$ margem esquerda: "XII'".

${ }^{155} \mathrm{Na}$ margem esquerda: "XIII ${ }^{\mathrm{O}}$ ".

${ }^{156}$ Na margem esquerda: "XIIII" ${ }^{\circ}$. 
${ }^{157}$ Item conposiçom antre o Spital e o bispo de Badalhouce na qual son conteudos os dereitos que o dicto bispo a d'aver d'algũas igrejas do Spital as quaes som Elvas e Serpa e Moura e o Crato.

${ }^{158}$ Item en como o Spital deu ao bispo do Porto herdades que aqui son conteudas por huum jantar que avia d'aver cada ano de Leça.

${ }^{159}$ Item conposiçom que e antre o Spital e o arcebispo per razom da igreja de Sam Momede de Gomide e de Santa Maria de Frogim. Outrosi he aqui conteudo como o Spital deu ao arcebispo o casal do Salgueyro que he en eserpos(?) e o casal de Lamaçaaes pelos dereitos que avia d'aver das sobredictas igrejas.

${ }^{160}$ Item carta d'escambho que fez o arcebispo de Bragaa com o Spital en que o arcebispo deu ao Spital os dereitos que avia en Santa Maria de Frogim e de Sam Momede de Godim e manda per esta sa carta aos freegueses que lhi respondam d'eles.

\section{(Fólio 11)}

${ }^{161}$ Item en como Gomez Alvitez deu ao arcebispo de Bragaa dous casaaes na Portela d'Ulvar e huum na Portela d'Escudeyros e huum meyo en Torneyros e dous no couto de Moysi (sic) por todolos dereytos temporaaes que o dicto arcebispo avya d'aver da igreja de Santa Maria de Biade.

${ }^{162}$ Item duas conposiçoens d'Antre Ambos Ryos en que he conteudo que apresente hũa vez o moesteyro d'Antranhos Ryos e a outra o Espital.

${ }^{163}$ Item carta de sentença que deu Dom Stevam bispo da Guarda de prazimento de frey Domingos priol do castelo de Sanhoanne do castelo da Vyde e de prazimento de Joham

\footnotetext{
${ }^{157}$ Na margem esquerda: " $\mathrm{XV} \mathrm{o}^{\mathrm{\prime}}$.

${ }^{158} \mathrm{Na}$ margem esquerda: "XVI"

${ }^{159}$ Na margem esquerda: "XVII",

${ }^{160}$ Na margem esquerda: "XVIII'",

${ }^{161} \mathrm{Na}$ margem esquerda: "XIX"

${ }^{162} \mathrm{Na}$ margem esquerda: " $\mathrm{XX}$ ".

${ }^{163} \mathrm{Na}$ margem esquerda: "XXI"
} 
Migenz priol de Santa Maria da Devesa e de prazimentos dos outros abades sobre as dizymas que demandava o freyre das pobras da Meiada e de Dom Martinho ${ }^{164}$.

${ }^{165}$ Doaçom que fez Johan'Eannes de Sarrãaos e seus filhos ao Spital do dereito do padroado que aviam de Santa Maria de Frogim.

${ }^{166}$ Item sentença pelos vigayros de Bragaa en que he conteudo que o dereito do padroado da Igreja de Frogim he do Spital.

${ }^{167}$ Item doaçom que fezerom Joham Migeez e Domingos Veegas ao Spital do dereito do padroado que avia na Igreja de Frogim.

${ }^{168}$ Item sentença dos ( sic) vigayro de Bragaa en que e conteudo que o dereito do padroado de Santa Maria [2 ${ }^{\text {a }}$ Coluna] de Frogim he do Spital e de como Per'Eannes e Orraca Affonso se quitarom ao Spital do dereito do padroado que avia na dicta igreja.

${ }^{169}$ Item en como Pero Rodriguiz deu ao Spital o dereito do padroado que avia na igreja de Santa Maria de Frogim.

${ }^{170}$ Item sentença pelos vygayros de Bragaa en que he conteudo que o dereito do padroado da igreja de Santa Maria de Frogim he do Spital.

${ }^{171}$ Item en como Pero Perez chantre de Visseu se quitou ao Spital do dereito do padroado que avia na igreja de Biade.

${ }^{172}$ Item sentença dos vigayros de Bragaa en que he conteudo que o dereito do padroado de Santa Maria de Frogim he do Spital e de como Pero Annes [e] Orraca Affonso se quitarom ao Spital do dereito do padroado que aviam na dicta igreja.

\footnotetext{
${ }^{164}$ No meio da primeira coluna, entre o último registro de uma contagem já terminada e o primeiro registro da nova contagem, existe esta frase escrita com letras pequenas: "Item dos padroados das igrejas dados ao Spitall" ${ }^{165} \mathrm{Na}$ margem esquerda: "Io". A letra inicial deste novo conjunto de registros é maiúscula e ornamentada.

${ }^{166} \mathrm{Na}$ margem esquerda: "II"

${ }^{167}$ Na margem esquerda: "III".

${ }^{168} \mathrm{Na}$ margem esquerda: "IIII'".

${ }^{169} \mathrm{Na}$ margem esquerda: " $\mathrm{V}$ ".

${ }^{170} \mathrm{Na}$ margem esquerda: "VI"

${ }^{171} \mathrm{Na}$ margem esquerda: "VII"
} 
${ }^{173}$ Item doaçom que fez Dona Stevaa Lopez ao Spital do padroado de Sant'Estevam do Maçaal termho de Celorico ${ }^{174}$.

${ }^{175}$ Item stormento de sentença per que a igreja de Sam Migel de Gadera he toda ysenta do Spital e esta en seu couto e na sua herdade e teras (sic) seus mareos.

${ }^{176}$ Item conposiçom antre ho Spital e o concelho de Cernancelhe sobrela Igreja de Sanhoane do dicto logo.

${ }^{177}$ Item trelado dũa carta d'el rey Dom Denis en que deu ao Spital o padroado destas igrejas de Sanhoane da Malva e de Cernoncelhi do bispado de Lamego e de Santa Maria do Mercado da Guarda e de Santiago de Fontes do bispado do Porto e de Sam Pero d'Aguiar do bispado de Viseu $^{178}$.

${ }^{179}$ Item carta de doaçom do padroado da igreja de Portel per como Dom Joham d'Avoim e sa molher derom ao Spital.

${ }^{180}$ Item doaçom que fez el rey Dom Sancho (fólio 12) ao Spital do padroado da igreja de Santa Maria do Mercado da Guarda.

${ }^{181}$ Item doaçom que fez el rey Dom Denis ao Spital da igreja d'Avreiro.

${ }^{182}$ Item doaçom que fez el rei Dom Denis ao Spital dos padroados das igrejas de Sam Joham de Marialva e de Sam Joham de Cernancelhi e de Santa Maria do Mercado da Guarda e de Santiago de Fontes e de Sam Pero d'Aguiar ${ }^{183}$.

\footnotetext{
172 Na margem esquerda: "VIII"

${ }^{173} \mathrm{Na}$ margem esquerda: "IX"

${ }^{174} \mathrm{Na}$ margem esquerda, escrita com letras pequenas, está a seguinte anotação: “Item doaçom da igreja do Maçall'”.

175 Na margem esquerda: " $\mathrm{X}$ "'.

${ }^{176} \mathrm{Na}$ margem esquerda: "XI"

177 Na margem esquerda: "XII'".

${ }^{178} \mathrm{Na}$ margem esquerda, escritas com letras pequenas, estão duas anotações: “doaçom de Sernancelhe(?)" e, mais abaixo "doaçom de Sam Pero d'Aguiar".

${ }^{179} \mathrm{Na}$ margem esquerda: "XIII ${ }^{\mathrm{O}}$ ".

${ }^{180} \mathrm{Na}$ margem esquerda: "XIIII"

${ }^{181} \mathrm{Na}$ margem esquerda: " $\mathrm{XV} \mathrm{V}^{\mathrm{o}}$.
} 
${ }^{184}$ Item doaçom que fez el rey Dom Denis ao Spital da igreja de San Martinho e de Samtiago de Portel.

${ }^{185}$ Item doaçom que fez el rey Dom Denis ao Spital do padroado da igreja de Santiago de Marvam.

${ }^{186}$ Item en como os herdeyros de Sam Momede derom essa igreja ao Spital.

${ }^{187}$ Item en como herdeiros de Sam Momede de Tresires derom essa igreja con todos seus dereitos ao Spital.

${ }^{188}$ Item conposiçom que foy feyta antre o Spital e o moesteiro de Samto Tirso, convem a saber, que abadassem per senhas vagaçoens a igreja de Santiago de Renardoens.

${ }^{189}$ Item stormento en como forom apresentados aa igreja de Sant'Adrãao de Santo(?) e quitarom se todos da demanda e os vigayros de Bragaa receberom apresentaçom do Spital.

${ }^{190}$ Item esta carta he per que Dona Tareiga fezerom con seus filhos doaçom da igreja de as (sic) Martinho da Erada ao Spital.

${ }^{191}$ Item esta carta he per que Dona Tareiga e seus filhos derom a igreja da Erada ao Spital.

${ }^{192}$ Item esta carta he per que Goterre Trutusendo deu a igreja de Maceeda ao Spital que he com so monte de Vilela.

[2a Coluna $]$

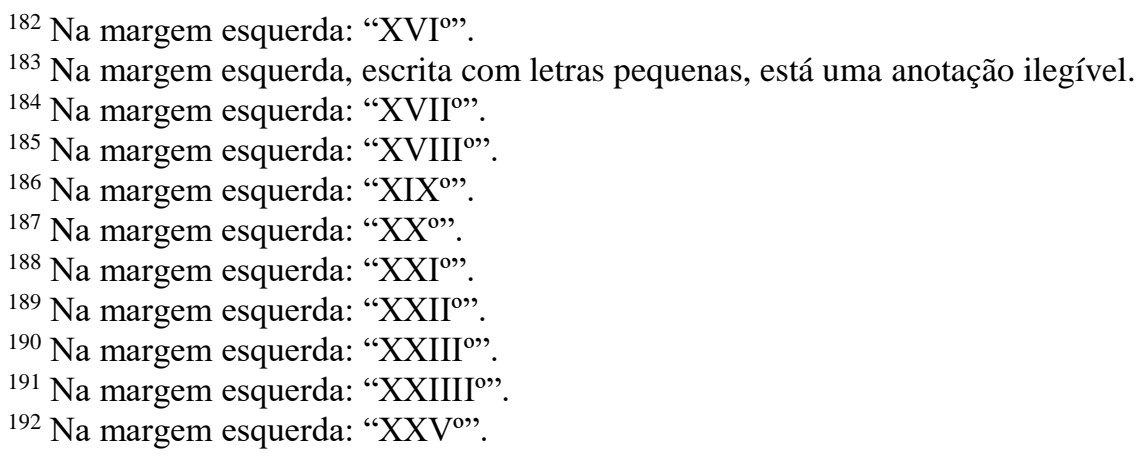


${ }^{193}$ Item en como muytos dadroeiros que aqui som conteudos derom ao Spital o dereito do padroado que aviam en Santiago de Lourosa.

${ }^{194}$ Item en como el rey Dom Sancho assynoou os termhos e coutos aa igreja de Santa Senhorinha de Basto.

${ }^{195}$ Item Stormento en como apelou o comendador de Curveira per razom da igreja de Santa Senhorinha de Basto.

${ }^{196}$ Item conposiçom que fez o Spital con ho arcebispo de Bragaa en que a por firme ao Spital o dereito de padroado de Santa Senhorinha de Basto se o guaanhar daqueles que no dicto padroado ham dereyto.

${ }^{197}$ Item en huum rool de XXXII cartas en que he conteudo que os herdeyros de Santa Maria de Biade derom o dereito do padroado que aviam na dita igreja ao Spital.

${ }^{198}$ Item carta en como el rey Dom Sancho mandou ao arcebispo que nom enbargasse a igreja de Santa Senhorinha ao Spital tal ha avia el dada per escambho.

${ }^{199}$ Item en como el rey Dom Affonso deu a meestre Alberte seu criado e seu fisico a igreja de Sam Joham de Rei pera el e pera seus sussesores e outorgou lhi quanto dereito en ela avia e outorgou lhy as doaçoens que aa dicta eigreja eram feytas per el e pelos outros e ouve as por firmes e por estaviis.

${ }^{200}$ Item hay huum rool en que a [...] VI cartas no qual he conteudo como os padroeiros da igreja de Sanhoane d'Ervoens derom o dereito do padroado que aviam na dicta igreja ao Spital.

\footnotetext{
${ }^{193} \mathrm{Na}$ margem esquerda: "XXVI".

${ }^{194} \mathrm{Na}$ margem esquerda: "XXVII ${ }^{\circ}$ ".

${ }^{195} \mathrm{Na}$ margem esquerda: "XXVIII"

${ }^{196}$ Na margem esquerda: "XXIX".

${ }^{197} \mathrm{Na}$ margem esquerda: "XXX".

${ }^{198} \mathrm{Na}$ margem esquerda: "XXXI"

${ }^{199} \mathrm{Na}$ margem esquerda: "XXXII".

${ }^{200}$ Na margem esquerda: "XXXIII"".
} 
${ }^{201}$ Item carta en como Dom Silvestre arcebispo de Bragaa ouve por firme as doaçoens que Gomez Alvitez e os outros padroeyros fezerom (fólio 13) ao Spital do dereito do padroado de Santa Maria de Byade.

${ }^{202}$ Item doaçom que fez Dona Orraca Sanchez ao Spital da meia da igreja de Fonte Arcada e da oytava da outra meiadade.

${ }^{203}$ Item en como muitos que aqui conteudos derom o dereito que aviam na igreja d'Ervoens ao Spital.

${ }^{204}$ Item en como Paay Maroco(?) e outros muitos derom ao Spital a igreja de Santa Maria de Frad'elos.

${ }^{205}$ Item en como muitos homeens derom ao Spital o dereito do padroado de Sam Salvador de Gahaaens(?).

${ }^{206}$ Item conposiçom antre o Spital e o moesteyro de Vandi per razom da igreja de Santa Ovaya de Palmeyra en que e conteudo que ha de dar o Spital hũa vagaçom e Vandym outra.

${ }^{207}$ Item doaçom que fez Joham Egoym e as molher con seus filhos e con seus hirmãaos ao Spital da meyadade da igreja de Santa Maria do Teixoso de Covilhaa ${ }^{208}$.

${ }^{209}$ Carta per que os vigayros de Lamego confirmarom huum clerigo que el rey Dom Affonso presentou aa igreja de Sam Joham de Marialva.

\footnotetext{
${ }^{201} \mathrm{Na}$ margem esquerda: "XXXIIII"

${ }^{202} \mathrm{Na}$ margem esquerda: "XXXV".

${ }^{203} \mathrm{Na}$ margem esquerda: "XXXVI"

${ }^{204} \mathrm{Na}$ margem esquerda: "XXXVII"

${ }^{205} \mathrm{Na}$ margem esquerda: "XXXVIII ${ }^{\circ}$ ".

${ }^{206} \mathrm{Na}$ margem esquerda: "XXXIX'".

${ }^{207} \mathrm{Na}$ margem esquerda: "XL".

${ }^{208}$ Abaixo do registro "XL", outra pessoa, posteriormente, escreveu mais três registros com letras reduzidas: "XLI", "XLII" e "XLIII". Esses acréscimos transcrevem-se assim:

"XLI Doaçom que fez el rey Dom Pedro de Portugal a Dom Frey Alvaro Gonçalvez priol do Spital do padroado da igreja de Santa Maria de Marvam.

XLII Doaçom que o dicto Rey fez ao dicto Priol do padroado da igreja de Santa Maria do Maçom.

XLIII Doaçom que fez el rey Dom Fernando de Portugal ao dicto frei Alvaro Gonçalvez priol do padroado da igreja de Santa Maria do Castel da Bide."

${ }^{209} \mathrm{Na}$ margem esquerda: "Io". A letra inicial deste novo conjunto de registros é maiúscula e ornamentada.
} 
${ }^{210}$ Item carta per que el rey Dom Donis mandou ao bispo de Lamego se ainda nom confirmara [2 $2^{\mathrm{a}}$ Coluna] huum clerigo que el apresentara a igreja de Sam Joham de Marialva que o nom confirmase e que o confirmase ${ }^{211}$ hy o que lhi o Spital apresentase.

${ }^{212}$ Item confirmaçom da igreja de Marialva a apresentaçom do Spital.

${ }^{213}$ Item confirmaçom da igreja de Cinfãaes a apresentaçom do Spital e da Ordem do Tenpre e foy hy confirmado Joham Vicente.

${ }^{214}$ Item confirmaçom en como Joham Vicente foy confirmado na igreja de Cinfãaes a apresentaçom da Ordem do Tenpre e da Ordem do Spital.

${ }^{215}$ Item confirmaçom da igreja de Cinfãaes a apresentaçom do Spital e da Ordem do Tenplo.

${ }^{216}$ Item confirmaçom da igreja de Fontes a apresentaçom do Spital.

${ }^{217}$ Item confirmaçom da igreja de Santiago de Fontes a apresentaçom do Spital.

${ }^{218}$ Item confirmaçom da igreja de Santa Maria de Ponteval a apresentaçom do Spital.

${ }^{219}$ Item carta per que foi confirmada Santa Maria de Freixeel a presentaçom do Spital.

${ }^{220}$ Item confirmaçom per como frei Domingos he confirmado na igreja da Vide a apresentaçom do Spital.

${ }^{221}$ Item confirmaçom da igreja de Sam Migel de Barreyros a apresentaçom do Spital.

\footnotetext{
${ }^{210}$ Na margem esquerda: "II

211 As palavras "Sam Joham" estão riscadas.

${ }^{212} \mathrm{Na}$ margem esquerda: "III" ${ }^{\circ}$ ".

${ }^{213}$ Na margem esquerda: "IIII

${ }^{214}$ Na margem esquerda: "Vo".

${ }^{215} \mathrm{Na}$ margem esquerda: "VI"

${ }^{216}$ Na margem esquerda: "VII"

${ }^{217}$ Na margem esquerda: "VIII"

${ }^{218}$ Na margem esquerda: "IX"

${ }^{219} \mathrm{Na}$ margem esquerda: " $\mathrm{X}$ ",

${ }^{220} \mathrm{Na}$ margem esquerda: "XI"

${ }^{221}$ Na margem esquerda: "XII'",
} 
${ }^{222}$ Item confirmaçom da igreja de Sam Migel de Barreiros a apresentaçom do Spital.

${ }^{223}$ Item confirmaçom en como em como (sic) foi confirmada a igreja de Sam Joham de Curveira do arcebispado a apresentaçom do Spital.

${ }^{224}$ Item confirmaçom da igreja de Santiago de Costoyas a apresentaçom do Spital.

${ }^{225}$ Item en como a igreja de Fonte Arcada foy confirmada a apresentaçom da Ordem do Spital e do Tempre(?) e do moesteyro da Cerzda (sic).

\section{(Fólio 14)}

${ }^{226}$ Item confirmaçom da igreja de Sant'Estevam do Maçaal a presentaçom do Spital.

${ }^{227}$ Item confirmaçom da igreja do Maçaal a apresentaçom de Dom Estevam Vaasquez.

${ }^{228}$ Item confirmaçom da igreja de Sam Frausto de Gueyfãaes do bispado do Porto a apresentaçom do Spital.

${ }^{229}$ Item confirmaçom da igreja de Sam Frausto de Gueyfãaes a apresentaçom do Spital.

${ }^{230}$ Item confirmaçom da igreja de Sam Frausto de Gueyfãaes a apresentaçom do Spital.

${ }^{231}$ Item confirmaçom da igreja de Sam Frausto a apresentaçom do Spital.

${ }^{232}$ Item confirmaçom da igreja de Santa Maria de Portel a apresentaçom do Spital.

\footnotetext{
${ }^{222}$ Na margem esquerda: "XIII" ".

${ }^{223} \mathrm{Na}$ margem esquerda: "XIIII"

${ }^{224} \mathrm{Na}$ margem esquerda: "XV".

${ }^{225} \mathrm{Na}$ margem esquerda: "XVI"

${ }^{226} \mathrm{Na}$ margem esquerda: "XVII"

${ }^{227} \mathrm{Na}$ margem esquerda: "XVIII"

${ }^{228}$ Na margem esquerda: "XIX").

${ }^{229} \mathrm{Na}$ margem esquerda: " $\mathrm{XX}$ ".

${ }^{230} \mathrm{Na}$ margem esquerda: "XXI"

${ }^{231} \mathrm{Na}$ margem esquerda: "XXII"".

${ }^{232}$ Na margem esquerda: "XXIII"
} 
${ }^{233}$ Item confirmaçom da igreja de Santiago de Revordãaos apresentaçom do Spital e do moesteyro de Santo Tirso.

${ }^{234}$ Item confirmaçom da igreja de Santa Ovaya de Sousela a apresentaçom do Spital.

${ }^{235}$ Item confirmaçom da igreja do Ameyxehedo a apresentaçom do Spital.

${ }^{236}$ Item confirmaçom da igreja de Santa Maria de Biade a apresentaçom do Spital.

${ }^{237}$ Item confirmaçom da igreja de Santa Maria de Frogim a apresentaçom do Spital.

${ }^{238}$ Item confirmaçom da igreja de Santa Maria de Frogim a apresentaçom do Spital.

${ }^{239}$ Item confirmaçom da igreja de Sousela de Cãaes apresentaçom do Spital.

${ }^{240}$ Item confirmaçom da Igreja de Santa Ollalha de Sousela a apresentaçom do Spital.

${ }^{241}$ Item confirmaçom da Igreja de Sam Joham de Cernancelhe a apresentaçom do Spital.

${ }^{242}$ Item confirmaçom da Igreja de Sam Martinho d'Aldoal a apresentaçom do Spital.

[2 $2^{\mathrm{a}}$ Coluna]

${ }^{243}$ Item confirmaçom da Igreja de Sam Martinho d'Aldoar a apresentaçom do Spital.

${ }^{244}$ Item confirmaçom da Igreja de San Martinho d'Aldoar a apresentaçom do Spital.

${ }^{233}$ Na margem esquerda: "XXIIII"

${ }^{234} \mathrm{Na}$ margem esquerda: "XXV".

${ }^{235} \mathrm{Na}$ margem esquerda: "XXVI"

${ }^{236} \mathrm{Na}$ margem esquerda: "XXVII" ".

${ }^{237} \mathrm{Na}$ margem esquerda: "XXVIII"

${ }^{238} \mathrm{Na}$ margem esquerda: "XXIX"

${ }^{239} \mathrm{Na}$ margem esquerda: "XXX".

${ }^{240} \mathrm{Na}$ margem esquerda: "XXXI"

${ }^{241} \mathrm{Na}$ margem esquerda: "XXXII"

${ }^{242} \mathrm{Na}$ margem esquerda: "XXXIII"

${ }^{243} \mathrm{Na}$ margem esquerda: "XXXIIII"

${ }^{244} \mathrm{Na}$ margem esquerda: "XXXV". 
${ }^{245}$ Item confirmaçom da igreja da Curtiçada en como a confirmou a Frey Lourenço.

${ }^{246}$ Item confirmaçom per como Frey Lourenço he confirmado na igreja de Santa Maria do Mercado da Guarda.

${ }^{247}$ Item confirmaçom da igreja de Sam Joham de Covas a apresentaçom do Spital.

${ }^{248}$ Item confirmaçom da igreja de Sam Joham d'Ervoens a apresentaçom do Spital.

${ }^{249}$ Item confirmaçom da igreja de Sam Joham d'Ervoens a apresentaçom do Spital.

${ }^{250}$ Item confirmaçom da igreja de Santa Maria de Taaxendi(?).

${ }^{251}$ Item confirmaçom da igreja de Sam Miguel da Gandera a apresentaçom do Spital.

${ }^{252}$ Item confirmaçom da igreja de Marvam per como a ela foi confirmado frei Domingos.

${ }^{253}$ Item confirmaçom de Sam Momede bispado do Porto a apresentaçom do Spital.

${ }^{254}$ Item a apresentaçom da Ordem do Tempre(?) e do moesteiro da Cerzeda e da Ordem do Spital foy confirmada aa igreja de Fonte Arcada.

${ }^{255}$ Item confirmaçom da igreja de Sam Momede a apresentaçom do Spital.

${ }^{256}$ Item como o bispo do Porto mandou que confirmase Sam Momede a Gonçalo Annes clerigo a apresentaçom do Spital.

\footnotetext{
${ }^{245}$ Na margem esquerda: "XXXVI"

${ }^{246} \mathrm{Na}$ margem esquerda: "XXXVII".

${ }^{247} \mathrm{Na}$ margem esquerda: "XXXVIII"".

${ }^{248}$ Na margem esquerda: "XXXIX"

${ }^{249}$ Na margem esquerda: "XL".

${ }^{250} \mathrm{Na}$ margem esquerda: "XLI"

${ }^{251}$ Na margem esquerda: "XLII"

${ }^{252} \mathrm{Na}$ margem esquerda: "XLIII"

${ }^{253}$ Na margem esquerda: "XLIIII"

${ }^{254} \mathrm{Na}$ margem esquerda: "XLV".

${ }^{255} \mathrm{Na}$ margem esquerda: "XLVI"

${ }^{256}$ Na margem esquerda: "XLVII"
} 
${ }^{257}$ Item sentença do bispo e dayam d'Evora juizes d'elegados do papa per que a igreja de Santa Maria dos Matos foi julgada ao Spital.

${ }^{258}$ Item en como o arcebispo de Bragaa julgou que o dereito do padroado da igreja d'Ervoes (fólio 15) perteece ao Spital. E logo confirmou a Frey Domingos na dicta igreja a apresentaçom do Spital.

${ }^{259}$ Item processo e enquiriçom que foi filhada per razom da igreja de Fonte Arcada antre a Ordem do Spital e ha de Tempre(?) e ho moesteiro da Cerzeda e o concelho de Fonte Arcada.

${ }^{260}$ Item proceso fecto antre os apresentados da igreja de Fonte Arcada.

${ }^{261}$ Item sentença que deu Mestre Joane chantre de Salamanca e Per'Eannes coonigo desse logo sobrela apelaçom que filhara Roi Martinz per razom da confirmaçom que fezera o vigairo de Lamego da igreja de Fonte Arcada a Gonçalo Martinz e foi julgado que o dicto Roi Martinz apelara bem. E porem o dicto Roy Martinz foi instituido na dicta igreja e o dicto Gonçalo Martinz remuvido.

${ }^{262}$ Item comisson da igreja de Santiago per razom da igreja da Fonte Arcada.

${ }^{263}$ Item en este processo ${ }^{264}$ he conteudo en como foy demanda antre alguns que forom apresentados aa igreja de Santa Maria do Ameyxeedo a qual foi confirmada a apresentaçom do Spital.

${ }^{265}$ Item en como foi confirmada a igreja de Santo Adrãao do arcebispado de Bragaa a apresentaçom do Spital.

${ }^{257}$ Na margem esquerda: "XLVIII"

${ }^{258} \mathrm{Na}$ margem esquerda: "XLIX".

${ }^{259} \mathrm{Na}$ margem esquerda: " $\mathrm{L}^{\mathrm{o}}$ ".

${ }^{260} \mathrm{Na}$ margem esquerda: " $\mathrm{LI}{ }^{\circ}$ ".

${ }^{261} \mathrm{Na}$ margem esquerda: "LII ${ }^{\mathrm{o}}$ ".

${ }^{262}$ Na margem esquerda: "LIII ${ }^{\circ}$ ".

${ }^{263} \mathrm{Na}$ margem esquerda: "LIIII"'.

${ }^{264}$ As palavras "foi demanda" estão riscadas.

${ }^{265} \mathrm{Na}$ margem esquerda: " $\mathrm{LV}{ }^{\circ}$ ". 
${ }^{266}$ Item confirmaçom da igreja da igreja ( ic ) de Sam Momede de Trasores a apresentaçom do Spital.

${ }^{267}$ Item en como foi confirmada a igreja de Santiago de Revordãaos a apresentaçom do priol e convento de Santo Tirso e do convento de Leça.

${ }^{268}$ Item confirmaçom da igreja de Santo Adrãao de anto (sic) a apresentaçom do Spital.

${ }^{269}$ Item trelado da confirmaçom de Cinfãaes a apresentaçom d'el Rey e do Spital.

${ }^{270}$ Item trelado de duas confirmaçoens da igreja de Santiago de Revordãaos a apresentaçom do [2 $2^{\mathrm{a}}$ Coluna] Spital e de Santo Tonsso(?).

${ }^{271}$ Item en como a apresentaçom do Spital foi confirmada a Igreja de [...].

${ }^{272}$ Item confirmaçom da Igreja de Santo [Steevam d']Ubreyro a apresentaçom do Spital pelo arcebispo de Bragaa.

${ }^{273}$ Item stormento en como o vygayro de Lamego confirmou a igreja de Reesende a apresentaçom do Spital.

${ }^{274}$ Item confirmaçom da igreja de Santa Ovaya de Palmeyra a apresentaçom do Spital e de Vandim.

${ }^{275}$ Item confirmaçom da igreja de Santa Ovaya de Palmeira a apresentaçom do Spital e de Vandim.

\footnotetext{
${ }^{266} \mathrm{Na}$ margem esquerda: "LVI"

${ }^{267} \mathrm{Na}$ margem esquerda: "LVII"

${ }^{268}$ Na margem esquerda: "LVIII",

${ }^{269} \mathrm{Na}$ margem esquerda: "LIX"

${ }^{270}$ Na margem esquerda: " $L X^{\circ}$ ".

${ }^{271} \mathrm{Na}$ margem esquerda: "LXI" ${ }^{\circ}$ ".

272 Na margem esquerda: "LXII ${ }^{\circ}$ ".

${ }^{273}$ Na margem esquerda: "LXIII"”.

${ }^{274}$ Na margem esquerda: "LXIIII"

${ }^{275}$ Na margem esquerda: "LXV".
} 
${ }^{276}$ Item confirmaçom da Igreja de Sam Vicente de Touges(?) a apresentaçom do Spital e do moesteyro d'Antranbros Rios.

${ }^{277}$ Item confirmaçom da igreja de Frogim a apresentaçom do Spital.

${ }^{278}$ Item confirmaçom que foy feita da Igreja de Sam Salvador de Figueyras a apresentaçom do Spital e doutros.

${ }^{279}$ Item confirmaçom como Domingos Nugeira foy confirmado na igreja de Santiago de Costoyas.

${ }^{280}$ Item confirmaçom como frei Domingos foi confirmado na igreja d'Ervoes.

${ }^{281}$ Item como a apresentaçom do Spital foi confirmada a igreja de Sam Martinho d'Aldoar do bispado do Porto.

${ }^{282}$ Item stormentos da demanda que o Spital ouve com o concelho d'Aguiar sobre a Igreja de Sam Pero do dicto $\log o^{283}$.

(Fólio 16)

Leça $^{284}$

${ }^{285}$ Privilegio de Celestino papa $\mathrm{III}^{\mathrm{o}}$ en que outorga aos freires do Spital que posam tomar por freires en sa Ordem quem lhis prouver e que os prelados nom lhis dem embargo sobr'esto.

\footnotetext{
${ }^{276}$ Na margem esquerda: "LXVI"'.

${ }^{277} \mathrm{Na}$ margem esquerda: "LXVII".

${ }^{278} \mathrm{Na}$ margem esquerda: "LXVIII ${ }^{\circ}$ ".

${ }^{279} \mathrm{Na}$ margem esquerda: "LXIX"

${ }^{280} \mathrm{Na}$ margem esquerda: "LXX"

${ }^{281} \mathrm{Na}$ margem esquerda: "LXXI"

${ }^{282} \mathrm{Na}$ margem esquerda: "LXXII"

283 Após esta frase o escrivão do documento fez três marcas (traços) para indicar o final da numeração. Abaixo do registro "LXXII ${ }^{\circ}$ " foi escrito, com outra letra, mais dois registros com letras reduzidas: "LXXIII" e "LXXIIII". Esses acréscimos transcrevem-se assim:

"Carta de confirmaçom da igreja de [...] do bispado do Porto.

Carta de como foy confirmada a igreja de Santa Maria de Marvom(?) [...]."

${ }^{284} \mathrm{Na}$ parte de cima da primeira coluna deste fólio está escrita a palavra "Leça". A partir desta parte do documento inicia-se uma lista de privilégios régios e pontifícios de várias comendas da Ordem do Hospital em Portugal, entretanto, esta transcrição abrange apenas os três primeiros fólios refentes aos privilégios da Comenda de Leça do Bailio (casa conventual até a primeira metade do século XIV).
} 
${ }^{286}$ Item privilegio de Innocencio papa IIII $^{\circ}$ en que manda que os prelados nom tevam pea por pecados que alguns homeens sojeytos do Spital ajam cometudos mays dem lhi peenden[...] qual virem que e convenhavel.

${ }^{287}$ Item privilegio de [Gregorio] papa nono en que manda que os arcebispos e bispos e prelados das outras igrejas nom demandem pea de dereitos aos vasalos do Spital que forem achados en adulterio ou en outro pecado com os privilegios que lhi som outorgados pelos reys e pelos outros senhores. E manda que nom ponham talhas quaes nom devem aas igrejas e clerigos do Spital.

${ }^{288}$ Item privilegio de confirmaçom de papa Clemente en que confirma todolos privilegios dos seus antecessores.

${ }^{289}$ Item privilegio de Innocencio papa III $^{\circ}$ en que manda que os prelados nom levem pea de dereitos dos sojeytos da Ordem mayas (sic) den lhis peendenças dos pecados que fezerem.

${ }^{290}$ Item privilegio de Nicolaao papa III $^{\circ}$ en que confirma todalas liberdades e privilegios que os predecessores outorgarom ao Spital e confirmarom todalas graças e liberdades que os reis e outros primcipes segraes outorgarom aa suso dicta Ordem.

${ }^{291}$ Item privilegio de papa Gregorio $\mathrm{XI}^{\mathbf{0}}$ en que confirma todalas liberdades e privilegios que os seus predecessores outorgarom ao Spital e confirma todalas graças e liberdades que os reis e os outros principes segraes outorgarom aa suso dicta Ordem.

[2 $2^{\text {a }}$ coluna]

${ }^{292}$ Item privilegio d'Aleyxandre papa IIII $^{\circ}$ en que confirma a conposiçom que el rey Dom Afonso conde de Belonha fez com os do seu reino na qual he conteudo que nom quebrantasem moeda el nem os que depos eles veesem.

\footnotetext{
${ }^{285} \mathrm{Na}$ margem esquerda: "I0". A primeira letra é maiúscula e ornamentada.

${ }^{286} \mathrm{Na}$ margem esquerda: "II

${ }^{287}$ Na margem esquerda: "III"

${ }^{288} \mathrm{Na}$ margem esquerda: "IIII"."

${ }^{289}$ Na margem esquerda: "Vo".

${ }^{290} \mathrm{Na}$ margem esquerda: "VI ${ }^{\circ}$ ".

${ }^{291} \mathrm{Na}$ margem esquerda: "VII"
} 
${ }^{293}$ Item privilegio de Innocencio papa en que manda aos arcebispos e bispos e outros prelados que digam e defendam aos seus sojeytos que nom filhem peageens nem portagees nem outras custumagees das cousas que forem pera comer ou pera vistir nem doutras cousas nenhũas que forem pera os freires do Spital ou pera os seus vasalos e se o fezerem que ponham en eles sentença de scumunhon e que nom cantem nem leam nem dem sagramentos nenhuuns salvo peendença e bautismo. Item manda que os clerigos do Spital nom celebrem nas igrejas do Spital que som intredictas por injuria ou mal que alguns fezerem en elas.

${ }^{294}$ Item privilegio de Honorio papa III $^{\circ}$ en que diz que alguns entendiam mal os privilegios do Spital e demandavam lhis dizimas dos barveiros, madeiras, feo, laa, linho, arvores de fruito e outras cousas semelhaviis. Manda per este privilegio que os freires nom paguem taaes dizimas.

${ }^{295}$ Item privilegio de Honorio papa $\mathrm{III}^{\mathrm{o}}$ en que manda seos freires do Spital filharem algũas terras a mouros possam en elas fazer igrejas e estas igrejas sejam tam solamente feitas ao papa.

${ }^{296}$ Item privilegio d'Aleyxandre IIII $^{\circ}$ en que manda aos freires do Spital que nom den procuraçoens e dereitos aos meseieiros do papa mayas (sic) den lhi domanda da Ordem.

${ }^{297}$ Item privilegio de Innocencio papa III $^{\circ}$ en que manda que os freires do Spital nem seus homeens nom pagem portajem nem peagem nem outra custumagem nenhũa das sas mandas nem das sas vistiduras (fólio 17) nem doutras cousas quaesquer nem dos gaados.

Leça $^{298}$

${ }^{299}$ Item privilegio de Innocencio papa IIII $^{\circ}$ en que os arcebispos e bispos nem outros prelados nom nom (sic) façam agravamentos aos freires do Spital. E manda que estes prelados nom ajam parte nenhũa das cousas que alguns em sa saude ou en sa enfirmidade ou que forem

\footnotetext{
${ }^{292}$ Na margem esquerda: "VIIII".

${ }^{293} \mathrm{Na}$ margem esquerda: "IX".

${ }^{294} \mathrm{Na}$ margem esquerda: " $\mathrm{X}$ ".

${ }^{295}$ Na margem esquerda: "XI"

${ }^{296}$ Na margem esquerda: "XII"

${ }^{297} \mathrm{Na}$ margem esquerda: "XIII"

${ }^{298} \mathrm{Na}$ parte de cima do fólio, centralizada, a palavra "Leça".

${ }^{299}$ Na margem esquerda: "XIIII"
} 
freegueses doutros logares ou en scolherem sepultura mandarem ao Spital pera mantiimento dos pobres. E manda que tam solamente ajam estes prelados a quarta parte das mortalhas que os freegueses do Spital madarem aa dicta Ordem en seu testamento. E parte que estes prelados nom demanden aa dicta Ordem parte das cousas que alguns em sa saude dam ao Spital en esmolhas. E manda se alguns mandarem ao Spital armas ou cavalos pera defendimento da Terra Santa em seu testamento que os prelados nom ajam ende parte. E manda que se alguns prelados nom quiserem dar maliciosamente confissoens ou comunhom aos seus fregueses que os clerigos do Spital possam asolver dos pecados ascondudos e dar lhys comunhom e aduzelos a soterrar en sas igrejas.

${ }^{300}$ Item privilegio de Celestino papa III $^{\circ}$ en que os prelados no ajam parte daquelas cousas que alguns en sa vida ou en sa infirmidade que freegueses som doutros ou escolhem sepultura e logares mandarem ao Spital. E manda que tam solamente estes prelados ajam a quarta parte das mortalhas que os freegueses do Spital mandarem aa dicta Ordem en seu testamento, salvo se forem armas ou cavalos de que os prelados nom devem aver parte nenhũa. E manda que estes prelados e nom ajam parte d'algũas cousas que alguns en sa vida derem ao Spital. E manda que se alguuns prelados maliciosamente nom quiserem dar confissoens ou cumunhom a seus freegueses que os clerigos do Spital os possam assolver [2 $2^{\mathrm{a}}$ coluna] dos pecados ascondudos e aduzelos a soterar aas sas igrejas.

${ }^{301}$ Item privilegio de Beento papa $\mathrm{XI}^{\mathrm{o}}$ en que confirma todalas liberdades e privilegios que os seus predece[sso]res outorgarom ao Spital e confirma todalas graças e liberdades que os reys e os outros principes segraes aa suso dicta Ordem.

${ }^{302}$ Item privilegio de Aleyxandre IIII $^{\circ}$ en que diz que non ajam os bispos dos igrejas do Spital se nom sas colheytas.

${ }^{303}$ Item privilegio de Celestino papa [... en] que e conteudo que alguns arcebispos e bispos e outros prelados davam olio e crisma aas igrejas do Spital e aos clerigos d'ordeens e consegravam as igrejas e diziam estes prelados que o Spital nom podia aver en sas igrejas

\footnotetext{
${ }^{300} \mathrm{Na}$ margem esquerda: "XV".

${ }^{301} \mathrm{Na}$ margem esquerda: "XVI"

${ }^{302} \mathrm{Na}$ margem esquerda: "XVII ${ }^{\circ}$ ".

${ }^{303} \mathrm{Na}$ margem esquerda: "XVIII ${ }^{\circ} "$
} 
porque as aviam sen seu outorgamento. Manda o papa que taaes escusaçoens come estas nom enbarguem as igrejas do Spital.

${ }^{304}$ Item privilegio de papa Innocencio III $^{\circ}$ en que manda que os freires do Spital possam soterrar os seus confreires en sas igrejas se os nom quiserem soterrar os prelados onde eram freegueses, salvo se forem escumungados ou nomeadamente intredictos.

${ }^{305}$ Item privilegio de Innocencio papa como filha so sa guarda e defendimento ho castelo de Belveer e deve ende aver en cada huum ano dous dinheiros d'ouro.

${ }^{306}$ Item privilegio de papa Innocencio IIII $^{\circ}$ en que manda que os freires do Spital nom paguem dizimas das possissoens e barveitos os quaes lavrarem per sas despesas ou per sas mãaos. Outrossi das pescarias e virgeos e ortas e criamentos de gaados que gaanhasem en qualquer tempo tambem ante do concelho come depoys.

${ }^{307}$ Item privilegio de Innocencio papa IIII $^{\mathbf{0}}$ en que confirma todolos privilegios liberdades que seus predecessores derom ao Spital. Outrossi todalas graças e liberdades (fólio 18) que os reis e os principes fezerom ao Spital.

Leça $^{308}$

${ }^{309}$ Item privilegio de Celestino papa III $^{\mathbf{0}}$ en que manda que todalas cousas que alguns en seu testamento ou en outra guissa qualquer derem ao Spital en presença de II $^{\mathrm{a}} \mathrm{s}$ ou três testemunhas sejam firmes e estaviis.

${ }^{310}$ En como el rey Dom Afonso ha por firmis todalas gaanças e doaçoens que forom feitas ao Spital e couta e confirma o Couto de Leça e quita os vasalos da Ordem de tributo e de servidoem e de coomha e manda que nom paguem portajem.

\footnotetext{
${ }^{304} \mathrm{Na}$ margem esquerda: "XIX"'.

${ }^{305} \mathrm{Na}$ margem esquerda: "XX"'.

${ }^{306} \mathrm{Na}$ margem esquerda: "XXI"

${ }^{307}$ Na margem esquerda: "XXII"',

${ }^{308} \mathrm{Na}$ parte de cima do fólio, centralizada, a palavra "Leça".

${ }^{309} \mathrm{Na}$ margem esquerda: "XXIII ${ }^{\mathbf{0}}$ ".

${ }^{310} \mathrm{Na}$ margem esquerda: "Io". A primeira letra é maiúscula e ornamentada.
} 
${ }^{311}$ Item trelados de cartas de confirmaçoens que fezerom el rei Dom Affonso e el rey Dom Sancho en que confirmarom e coutarom todalas doaçoens liberdades e coutos que el rey Don Afonso e el rey Dom Affonso fezerom ao Spital.

${ }^{312}$ Item carta d'el rey Dom Sancho de confirmaçom en que confirma todalas graças e liberdades que o Spital ouve pelos seus antecessores e en que lhi el da outras.

${ }^{313}$ Item carta d'el rey Dom Denis en que confirma todolos privilegios do Spital.

${ }^{314}$ Item carta en como el rey Dom Sancho mandou alçar ao Spital os coutos de Gond[im] que lhi alguns cavaleiros seus vizinhos abaixarom e de mais lhe mandou aver a vila assi como ante avia.

[2 $2^{\mathrm{a}}$ coluna]

${ }^{315}$ Item trelado en que som conteudas cartas d'el rey Dom Afonso e d'el rey Dom Denis de graças que fezerom ao Spital nas quaes he conteudo que os vasalos do Spital nom dem geiras nem outros serviços aos filhos d'algo nem a outros nenhunns. Item e manda que as justiças nom sospam(?) a nenhuns que façam mal nem força aos que moram nas herdades do Spital.

${ }^{316}$ Item trelado d'hũa carta d'el rey Dom Denis de graça en que manda que nom entrem saioes nem porteiros nas herdades e logares do Spital nem paguem nas talhas nem peytem voz nem coomha nenhũa.

${ }^{317}$ Item trelado d'hũa carta d'el rey Dom Afonso en que manda que cavaleyros ricos homeens nem outros nom façam mal nas herdades do Spital. E manda aos juizes cada huum en sas comarcas que nom sofram a nenhuuns que lhys força faça nem mal.

\footnotetext{
311 Na margem esquerda: "II ${ }^{\circ}$ ".

${ }^{312} \mathrm{Na}$ margem esquerda: "III" ${ }^{\circ}$ ".

${ }^{313} \mathrm{Na}$ margem esquerda: "IIII'",

${ }^{314} \mathrm{Na}$ margem esquerda: " $\mathrm{V}$ ",

${ }^{315} \mathrm{Na}$ margem esquerda: "VI"

${ }^{316} \mathrm{Na}$ margem esquerda: "VII"

${ }^{317}$ Na margem esquerda: "VIII ${ }^{\circ}$ ".
} 
${ }^{318}$ Item carta d'el rey Dom Afonso en que manda que os homeens que moram en Alvarelhos nas herdades do Spital nom paguem talhas nem colheitas com os do concelho de Monforte.

${ }^{319}$ Item en como foy julgado per sentença que o Spital mandasse penhorar per seus freires [...] homeens moradores de sagraes freeguisia de Santa Maria de Choroso polos encençorias e dereitos que em am d'aver.

${ }^{318}$ Na margem esquerda: "IX"

${ }^{319}$ Na margem esquerda: " $\mathrm{X}$ "”. 


\section{REGRA DA ORDEM DE SÃO JOÃO DE JERUSALÉM \\ BIBLIOTECA DA AJUDA, 49-II-32, FLS. 245-258.}

(Fólio 245)

Privilegios concedidos pelos Sumos Pontífices à Ordem de São Joam.

\section{Martinho $5^{\circ}$}

Concedeo Martinho quinto a Ordem que todas as querellas, questõis, demandas, causas e controversias nacidas de quaisquer occasiõis entre os frades e súbditos do Hospital de São João sejão julgados ate sentença diffinitiva pelo Grão Mestre e convento, ou pelos frades a que pelo Grão Mestre e convento forem cometidos. Visto com todos seus incidentes, anexos e connexõis e sem appellação. E poderão ser ouvidos pelos ditos juizes comissarios ou Grão Mestre e convento ata a terceira sentença diffinitiva so poderão appellar pera a See Appostolica em casso que se lhe não averde a justiça nem se guardem os estabelicimentos e costumes da Ordem. E serão obrigados os tais frades e subditos (fólio 245-verso) a aparecer diante dos ditos juizes posto que esterão em lugares muito remotos. E os que appellaram pera outros juizes ou citarem diante de outros quaisquer que sejão encorrem em pena de excomunham. E pelo mesmo casso perderão a causa e cousa sobre que assi litigarem.

\section{Sixto $4^{\circ}$}

Concedeo que todas as collaçõis, provisõis, uniõis, annexaçõis e incorporaçõis ou quaisquer outras concessõis das comendas e mais benefícios da Ordem não vallesem, posto que fosem dadas pela See Appostolica se não dando as o Grão Mestre e convento. E os que de outra maneira possuírem os ditos benefícios fiquão excomungados de excomunham reservada a $\mathrm{Se}$ Appostolica. E sendo frades da Ordem se por hum mês tiverem os ditos benefícios perdem tudo o que tiverem da dita Ordem e o Grão Mestre pode prover (fólio 246) delles como lhe parecer e os intrusos ficão inhabilitados pera alcançarem outros.

Innocencio $8^{\circ}$ 
Concedeo que nhũa excepção escusasem aos religiosos da obediencia e pagamento das responsõis ao comum thesouro. E que os beneficios da Ordem posto que vagasem na See Appostolica se provesem pelo Grão Mestre e convento e não entendesem nelles as reservas e que os privilegios em contrario concedidos não valhão nem os que se proverem contra esta determinação tenham nelles posse, dereito nem titolo corado, nem thes valha a regra de trienali possessioem. $\mathrm{O}$ mesmo concedeo Julio $2^{\circ}$ em mais larga forma e confirmou as indulgencias e previlegios dos sumos pontifices seus predecessores.

\section{Leão 10}

Concedeo que o Grão Mestre e convento pudesse deputar em cada priorado hum vigairo geral que pudese dar beneficios da Ordem e ansianidades e por em (fólio 246v) elles as pensois e responsõis ao diante ditas(?) e dispensar na idade e defecto de nacimento com os inhabeis pera os beneficios da Ordem soomente. E que as letras do Grão Mestre e convento se desse credito e tanto que fossem expendidas fiquasem logo confirmadas. E que não vallesem as doações de bens em mão(?) mais que pertencecem a Ordem. E nos beneficios se não pudesem por nhuns emcargos posto que fossem pedidos que emperadores, reis, cardeais, prelados, duques, princepes, marquezes, universidades, estados cenção(?) de dereito ou por evitar escandalos e demandas ou por causa da Se Chatolica ou de navios de infieis ou outra qualquer grande consideração.

\section{Clemente 7}

Concedeo ao Grão Mestre plenaria jurisdição de mero e mixto imperio nas pessoas e bens da Ordem e faculdade pera proceder contra os re-(fólio 247)veis e contumazes e os privar dos beneficios, redditos e fruitos e os arendar posto que sejão pessoas seculares ou regulares de outra ordem tendo beneficios da Ordem.

Que possão ter hum procurador geral na Curia Romana que tenha poder de dar beneficios posto que sejão reservados em titolo ou ad nutum removiveis e possa fazer uniõis e desmembrar e conceder ansianidades e tenha poder de aceitar as renunciaçõis posto que tenhão clausula de se reservar pera os resignantes titolo, fruitos e pensõis.

Que possão publicar as indulgencias concedidas pela See Appostolica sem licença dos ordinarios com soo o sello do prior daquella provincia ou do conservador da Ordem. 
Que possão ter adros nas igrejas parrochiaes da Ordem onde possão enterrar em tempo de interdicto todas as pessoas, salvo o dereito do rector ou (fólio $247 \mathrm{v}$ ) cura e não tendo as tais pessoas dado causa ao interdicto.

Que possão receber os sacramentos em quaisquer igrejas e receber ordens de qualquer bispo.

Que elles e seus criados possão trazer todas as armas.

Que seus capellães os possão confessar a elles e seus vassalos subditos e familiares e administrar lhes os mais sacramentos. E poderão os tais capellães dizer lhes missa em tempo de interdicto em voz baixa deitados os excomungados fora e com portas fechadas.

Que em qualquer parte da Cristandade possão fazer igreja da Ordem, dando lhe sustentação conveniente.

Que não valhão os alheamentos feitos sem consentimento do Grão Mestre e convento, posto que sejão confirmados pela See Appostolica, jurados ou per escrituras publicas.

Que as causas beneficiaes entre quaisquer pessoas se tratem diante o Grão (fólio 248) Mestre e convento. E poderão ser citados os contendores conforme o dereito. E poderão inhibir os mais juizes e dar a execução suas sentenças.

São demandas de baixo da protecção da Se Appostolica e isentos de toda a outra jurisdição que não for da Ordem as igrejas e religiosos da Ordem, suas couzas e seus bens, seus subditos, vassallos, lavradores e criados e os clerigos de missa que tiveram beneficios curados da Ordem e todas suas cousas, animais, campos, cazas, moinhos e todos os mais bens e isentos de toda a jurisdição, correcção, estatutos, dominio, superioridade e poder de quaisquer patriarcas, arcebispos, bispos, prelados e quaisquer bens temporães posto que sejão emperadores, reis, duques ou universidades em toda a parte do mundo.

E que sejão livres de todo o tributo pasagii, arreagii, gabellae, datii, trae-(fólio 248v)tae, collectae, procurationis, iacunali adventus, iurium etiam sinodalium sensuis(?) et decimarum etiam novalium et hortorum, pratorum, piscatiorum et molendinorum.

Concedeo que não tivesem nas sobredictas jurisdição (sic) os prelados nem ordinarios, nem ainda rationem delictio contractos contra o qual não val a prescripção em contrario o que tudo guardarão os prelados sob pena de excomunham santae sententiae. Encorrem ipso facto em restituição do dano que nisso derem as partes em quatro dobro.

Concedeo que não ouvesse jus patronatos nos beneficios da Ordem e avendo o por rezão da fundação do beneficio que o Grão Mestre o possa remir. E que se não possão dar pensõis nos benefícios da Ordem pela See Appostolica e dando se não valhão e que se não dem os beneficios se não aos religiosos da Ordem. E que não possão servir nas igrejas parrochiais da 
(fólio 249) Ordem clerigos sem o habito salvo de consentimento do prior, bailio ou comendador. E que se não ponhão mãos violentas nos que sejam contra as igrejas da Ordem. Que os bailios, prior e mais religiosos possão fazer conservador ao qual se daa poder de proceder contra os que fazem contra os previlegios da Ordem.

Paulo $3^{\circ}$

Confirmou todos estes previlegios e acrecentou que os bens da Ordem se não desem em prazo perpetuo ou tatiosim se não em três vidas e os que fossem dados em tatiota não vallesem mais tempo que noventa e nove anos. E que querendo o Grão Mestre ou os priores e bailios e mais religiosos, os beneficios que sempre andarão em clerigos seculares os pudesem dar (fólio 249v) a clerigos do habito de São João.

Pio $4^{\circ}$

Confirmou os mesmos previlegios e os estabelimentos e prohibio que se não appellasse se não pera os juizes dados pela Ordem e delles pera o capitolo geral.

Concedeo que todas as sentenças, comissõis, citaçõis e rescriptos do Grão Mestre e convento se dem a execução sem mais informação e consentimento algum dos prelados. E se proceda contra os seculares e regulares que deverem a Ordem assi como se proceda contra os religiosos da Ordem. E que os conservadores da Ordem gozem dos privilegios della.

Concedeo que os religiosos da Ordem e seus capellães onde quer que estiverem não paguem dizimas nenhũas, imposiçõis ou subsidios de seus beneficios (fólio 250) concedidos assi em Espanha como França. E que possão levar livremente os fruitos das comendas onde quer que quiserem sem pagar dereitos alguns.

Concedeo que os priores fossem ordinarios em seus priorados.

Concedeo que nenhũa cousa se entendese julgada em perjuizo do convento sem pera isso ser chamado.

(Fólios 250v, 251 e 251v: em branco) 
(Fólio 252)

Privilegios dos reis

El rei Dom João $2^{\circ}$

Dom João per graça de Deus rei de Portugal e do Algarve, a todolos meirinhos, corregedores, juizes e justiças de nosos reinos e outros quaisquer que esto ajão de ver, que esta carta virdes ou o treslado della em publica forma saude. Sabede que Frei Alvaro Gonçalves cavaleiro prior das cousas que a Ordem do Hospital ha em os ditos reinos disse que elle e sua ordem hão provedores caseiros e lavradores e cerviçais que lhe lavrão e aporveitão as herdades da dita sua ordem e que ora por rezão destas guerras, os constrangem que paguem em fintas e em talhas e em peitas e d'alguns encargos dos conselhos donde são moradores e outrosi que sirvão com elles (fólio 252v) e demais que lhe tomão suas bestas e gados, pão e vinho e outras cousas contra suas vontades pela qual rezão o dito prior diz que as ditas suas erdades da dita sua ordem se não lavrão nem aporveitão despovorão pelos muitos males e danos e sem rezõis que recebem os sobreditos. E que elle porem não ha as rendas das ditas suas erdades nem as pode aver pelo que dito he, e que porem não tem com que nos servir possa como cumpre a noso serviço, pois que se assi as ditas suas erdades e rendas delle falecem, pedindo nos o dito prior por merce que a esto lhe ouvesemos remedio, por tal guissa que elle nos pode servir. E nos vendo o que nos pedia, e outrosi como elle anda em nosso serviço em esta guerra que avemos e lhe pera ello muito mister he as rendas das ditas suas herdades pera com (fólio 253) ellas nos aver de servir. E em como os ditos provedores, caseiros e lavradores e serviçais são previlegiados e isentos de todo o que dito he. E querendo lhe fazer graça e merce pelo muito serviço que delle recebemos e entendemos de receber a diante temos por bem e mandamos que não embargando algũas cartas nem alvaras que sejão dados ante desta carta nem depois nenhum outro mandado especial que disto vejades em contrario que não constrangades nem mandeis constranger que pagem en fintas nem em talhas ${ }^{1}$ nem em peitas neenhuns encargos dos conselhos, nem sirvão com elles nenhũa cousa, salvo com o dito prior, nem lhes tomedes nem consintades a nenhũa pessoa que lhes tome seus pães, nem vinhos, nem bestas, nem gados, nem nhũa outra cousa das en contra suas vontades (fólio 253v) e se lho algũas pessoas tomarem que lhes alcedes delles força e lho façades logo tornar. E mandamos vos que lhes façades guardar e comprir esta nossa carta ou treslado dela em publica forma segundo em ella

\footnotetext{
${ }^{1} \mathrm{Na}$ margem direita está escrito "hic".
} 
he conteudo. E lhes confirmamos por esta nossa carta todalas cartas e previlegios e liberdades que a dita Ordem ha dos papas e dos reis nossos antecessores que forão pela guisa e em elles são conteudos. E mandamos que lhe sejão guardados todos os coutos e honrras pela guissa que nos ditos previlegios he conteudo. E não lha querendo vos guardar e comprir, mandamos a qualquer tabalião dos ditos nossos reinos a que esta carta for mostrada ou o treslado della em publica forma segundo dito he que vos cite per ella que a dous nove dias pareçades perante nosos sobre juizes de nossa corte e mandamos ao noso pro-(fólio 254)curador que vos demande pelos nossos emcoutos. E outrosi mandamos ao nosso almoxarife que for de lugar onde assi fordes demandadas que os recadem e ajão pera nos onde vos e elles al não façades, dante no Araial de Sobre Chaves a 27 dias de Abril. El rei o mandou, Martim Gonçalves a fez. Era de 1424.

Previlegio d'el rei Philippe $2^{\circ}$

Nosso Prior

Eu el rei faço saber aos que este alvara virem que eu (sic) por bem e me praz por me pedir o cardeal archiduque meu muito amado e prezado sobrinho e irmão que elle como governador e administrador que ora he do priorado do Crato da Ordem de São João do Hospital de Hierusalem possa usar e use de todos os previlegios, liberdades e graças que pelos reis destes (fólio $254 \mathrm{v}$ ) reinos meus antecessores forão concedidos aos priores que forão do dito priorado e dos que el rei Dom João meu senhor <que Deus tem> concedeo ao iffante Dom Luis seu irmão prior que foi do mesmo priorado de que os ditos priores e iffante estiverão de posse e isto enquanto eu não estiver em despacho de confirmaçõis notifico o assi a todos os meus desembargadores, corregedores, ouvidores, juizes e justiças, officiaes e pessoas a que o conhecimento disto pertencer e lhes mando que em todo cumprão e fação enteiramente comprir e guardar este meu alvara como nelle se contem o qual quero que valha e tenha força e vigor como se fosse carta feita em meu nome per mim assinada e passada per minha chancellaria sem embargo da ordenação do 2 livro, fl.20 que diz que as cousas cujo effecto ouverem de durar mais de hum ano (fólio 255) passem per cartas e passando per alvara não valhão. António Rodriguiz a fez em Lisboa a 21 de Maio de 1586. Simão Borralho a fez escrever $[\ldots]$.

Verba do Previlegio d'el rei Dom Sancho 
Outorgou e comfirmou todas as suas posuiçõis que nhũa pessoa não seja ousada os termos seus que rompera ou de suas cazas ou erdades ou que prenda seus homens ou em algũa maneira algum seu a molestar ou offender em algũa cousa e que de calúnia ou coima que os seus homens fizerem pessoa algũa não seja ousada de hi nada levar nem aver o que tudo enteiro sem quebramento concedeo com suas erdades e com todos os termos dos outros seus coutos e outorgou que permanececem em sua firmissima fortaleza, mais (fólio 255v) absolveo e quitou e livrou os homens que morasem em suas herdades de todo negocio e obra serviçal e de todo tributo e cedeo ainda que se alguem nas outras suas erdades cometer algum destes tres maleficios, convem a saber, homicidio, furto ou rouço realmente ou autuamente e se possa legitimamente provar o que tal maleficio cometer compora por elle segundo sua possibilidade pero a Ordem nunca per isso perdera sua caza nem algũa cousa de seu do que ende ouvese. E que daquellas cousas que por composição pagasse desse a metade a elle e a outra ametade ficasse na erdade concedeo lhe ainda mais que de qualquer cousa que os seus homens trouxesem do que rendião ou pagavão de oro ou dereito em suas terras nem de cousas que dellas comprassem nem vendessem nom pagassem nem levasem al-(fólio 256)guma portagem. Disse ainda mais e mandeo que nunca aos irmãos do Hospital ou aos seus fosse posto penhora nem prenda em nhũa cousa salvo se primeiro em presença sua a cousa per que os penhorasem fosse trazida e alegada perante o dito prior e freires. E quis que as cousas dos ditos freires sempre por informação e conhecimento de bons varõis fosse e seja determinada. E ultimamente quis e mandou que qualquer que esta sua esmolla quebrantasse ou diminuisse ou algũa cousa tomase inteiramente se onde(?) cabo restituisse e tornasse a seu dono e alem composese com nome de pena quinhentos soldos de moeda aprovada, os quais a metade concedeo a casa de Deus e aos pobres della e que fosse maldito e excomungado e apartado e sagregado do consor-(fólio 256-verso)cio perpetuamente dos barõis sanctos outorgou esta carta com consentimento dos seus conegos Dom João arcebispo de Braga e Dom Aires prior que então era, ao qual e a todos seus socesores deu licença que com justa causa comungassem os que algum freire fizesem injuria e que aquelles que assi por elle (sic) fossem excomungados não fossem recebidos nas igreja até que a elle assi satyfizese. As quais cousas o dito rei concedeo e perpetuamente outorgou lho na Era de duzendos e vinte aos cinco dias de Julho de comum com sua molher e seus filhos e filhas por taes muitos prelados do reino e outros alguns senhores e officiais maiores da caza d'el rei e da rainha, a qual avia pela [...] de seu pai e em remissão de seus peccados e a honrra de Deus e de São João Baptista. 
Verba de outro previlegio d'el rei Dom João $1^{\circ}$

E nos vendo o que nos pedia e outrosi por que somos certo que os ditos seus cazeiros e lavradores e cerviçais da dita sua ordem que não paguem nos ditos serviços e ajudas de pão, de vinho, nem de carne, nem de levados, nem de dinheiros, nem de nhũas outras cousas que pelos sobreditos nem por outros nenhuns sejão pedidos nem demandados per qualquer guissa que seja outrogado pelos juizes e procuradores das ditas pessoas terras onde assi os ditos cazeiros, lavradores, serviçais sejão moradores, nem lhe consintades aos ditos cavaleiros escudeiros e pessoas que tenhamos dados ou dermos nossas terras, nem aos ditos juizes que os por as ditas cousas nem por outras algũas constrangão por que em ellas paguem nem sejão penhorados por a dita rezão. Outrosi mandamos que não consintades que os ditos cavaleiros e es-(fólio 257v)cudeiros ou outros quaisquer ponhão nem tenhão seus homens nem suas bestas nas aldeas, casais e lugares da dita sua ordem nem pousem em ellas em nhũa guissa que seja e se lhes algum pão ou vinho ou direitos inteiros ou outras cousas algũas tem tomadas ou por a dita rezão são penhorados e lhes façades logo entregar todo e pagar sem nnhum outro embargo. Outrosi lhes alcedes força de qualquer pessoa ou pessoas que lhes algũa cousa tomarem ou outros alguns males sem rezõis fizerem que nossa merce he que os ditos cazeiros e lavradores e serviçais sejão coutados e previlegiados e libertados pela guissa que dito he e qualquer de vos justiças que sobre esta rezão fordes requeridos sede certos que se o contrario dello fizerdes que o pagaredes em tres dobro ao dito prior todo aquillo que assi for pedido e tomado aos sobreditos seus cazeiros e lavradores (fólio 258) e serviçais e toda a perda e dano que elle pela dita rezão receber e de mais mandamos a qualquer tabalião a que esta carta for mostrada ou o treslado della em publica forma que vos empraze que a tres nove dias pareçades perante nos mostrar rezão por que não quizestes guardar e comprir esta nossa carta como se nella contem e outrosi pera volo nos estranharmos gravemente nos corpos e nos averes e como aquelles que não cumprem o mandado de seu rei e senhor. Donde al não façades, dante em a cidade de Lamego a 25 dias de Julho. El rei o mandou Afonso Martinz a fez. Era de 1424 anos. 